NOAA Technical Report NMFS Circular 417

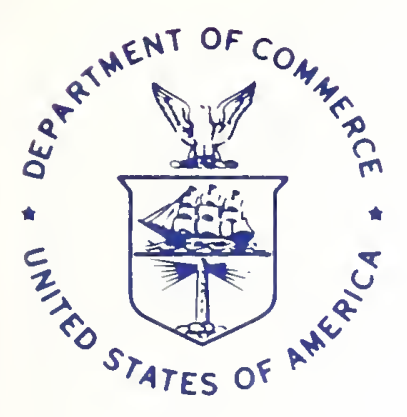

\title{
Guide to the Identification of Genera of the Fish Order Ophidiiformes With a Tentative Classification of the Order
}

Daniel M. Cohen and Jørgen G. Nielsen

December 1978

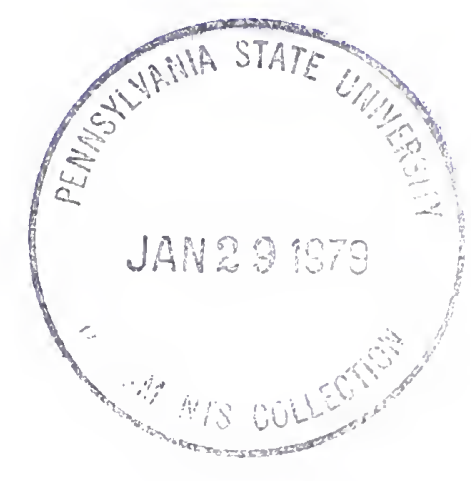

U.S. DEPARTMENT OF COMMERCE

National Oceanic and Atmospheric Administration National Marine Fisheries Service 


\section{National Marine Fisheries Service, Circulars}

The major responsibilities of the National Marine Fisheries Service (NMFS) are to monitor and assess the ahundance and geographic distribution of tishery resources, to underst and and predict fluctuations in the quantity and distribution of these resources, and to establish levels tor optimum use of the resources. NMFS is also charged with the development and implementation of policies for managing national fishing grounds. development and enforcement of domestic fisheries regulations, surveillance of foreign fishing off United States coastal waters, and the development and enforcement of international fishery agreements and policies. NMFS also assists the fishing industry through marketing service and economic analysis programs, and mortgage insurance and vessel construction subsidies. It collects, analyzes, and publishes statistics on various phases of the industry

The NOAA Technical Report NMFS Circular series continues a series that has heen in existence since 1941. The (irculars are technical publications of general interest intended to aid conservation and management. Puhlications that review in considerahle detail and at a high technical level cert ain hroad areas of research appear in this series. Technical papers originating in economic's studies and from management in. vestigations appear in the Circular series.

VOAA Technical Report NMFS Circulars are available free in limited numhers to governmental agencies, hoth Federal and State. Thev are also available in exchange for other scientific and technical publications in the marine sciences. Individual copies may he obtained (unless otherwise noted) from D825, Technical Information Division. Environmental Science Information ('enter, NOAA. Washington. I).('. 202:35. Recent Circulars are:

365. Processing EASTROPAC STD data and the construction of vertical temperature and salinity sections by computer. By Forrest R. Miller and Kenneth A Bliss. Februar: 1972, iv +17 p., 8 figs., 3 app. figs. For sale by the Superintendent of Documents, U.S. Government Printing Office, Washington. D.C. 20402

366. Key totield identification of a nadronnus juvenile salmonids in the Pacific Northwest. By Rohert J. MacConnell and George R. Snyder. January 1972, iv +6 p. 4 figs. For sale by the Superintendent of Documents, U.S. Government Printing Office, Washington, D.C. 20402.

367. Engineering economic model for fish protein concentration processes. By K. K. Almenas, L. C. Durilla, R. C. Ernst, J. W. Gentry, M. B. Hale, and J. M. Marchello. Octoher 1972, iii +175 p., 6 figs., 6 tahles. For sale by the Superintendent of Documents, U.S. Government Printing Office, Washington. D.C. 20402.

368. Conperative Gulf of Mexico estuarine inventory and study. Florida: Phase 1, area description. By J. Kneeland McNulty, William N. Lindall. Jr., and James E. Sykes. November 1972, vii + 126 p., 46 figs., 62 tables. For sale hy the Superintendent of Documents, U.S. Government Printing Office, Washington, D.C. 20402.

369. Field guide to the anglefishes (Pomacanthidae) in the western Allantic. By Henry A. Feddern. Novemher 1972, iii + 10 p., 17 figs. For sale by the Superintendent of Documents, U.S. Government Printing Office, Washington, D.C. 20402

370. Collecting and processing data on fish eggs and larvae in the California Current region. By David Kramer, Mary J. Kalin, Elizabeth G. Stevens, James R. Thrailkill, and James R. Zweifel. November 1972, iv +38 p. 38 figs., 2 tables. For sale by the Superintendent of Documents, U.S. Government Printing Office, Washington, D.C. 20402.

371. Ocean fishery management: Discussion and research. By Adam A. Sokoloski (editor). (17 papers, 24 authors.) April 1973, vi + 173 p., 38 figs.. 32 tahles, 7 app. tables.

372. Fishery puhlications, calendar year 1971: Lists and indexes. By Thomas A. Manar. October 1972, iv +24 p., I fce. For sale by the Superintendent of Documents, U.F. Government Printing Office, Washington, D.C. 20402.

374. Marine flora and fauna of the northeastern United States. Annelida: Oligochaeta. By David G. Cook and Ralph O. Brinkhurst. May 1973, iii +23 p., 82 figs. For sale by the Superintendent of Documents, L.S. Golernment Printing Office, Washington, D.C. 20402.

375. Vew Polychaeta from Beaufort, with a key to all species recorded from Vorth Carolina. By John H. Day, July 1973, xiii +140 p., 18 figs., 1 table. For sale by the Superintendent of Documents. U.S. Government Printing Office, Washington, D.C. 20402.

376. Bottom-water temperatures on the continental shelf, Nova Scotia to New Jersev. By John B. Colton. Jr. and Ruth R. Stoddard. June 1973. $\mathrm{iii}+55$ p., 15 figs., 12 app. tables. For sale hy the Superintendent of Documents, U.S. Government Printing Office, Washingt on. D.C. 20402.
377. Fishery puhlications, calendar vear 1970): Lists and indexes. By Mary Ellen Engett and Lee $C$. 'Thorson. Decemher 1972, iv +34 p., 1 fig. For sale by the Superintendent of Doruments, U.S. Government Printing Office. Washington, D.C. 20402.

3ix. Marine flora and fauna of the northeastern I'nited States. I'rotonal: ('iliophora. Bv Art hur C. Borror. Septemher 1973, iii + 62 p.,5) ligs. For sale by the superintendent of Documents, I.s. Government Printing (office. Washington, 1), C. 20(4)2.

379. Fishery puhlications, calendar vear 1969: I ists and indexes. By Lee (c. Thorson and Mary Ellen Engett. April 1973, iv + 31 p., 1 fig. For sale hy the Superintendent of Documents, U.S. Government Printing Office. Washington. D.C. 2010402.

38(1). Fishery publications. calendar vear 1968: Lists and indexes. By Marv Ellen Engett and lee $C$. Thorson. Mav 1973, iv + 24 p., 1 fig. For sale by the Superintendent of Documents, C.S. Grovernment Printing Office. Washington. D. ('. 2040?

381. Fishery puhlications, calendar year 1967: Lists and indexes. By Lee (C. Thorson and Mary. Ellen Engett. July 1973, iv +22 p., 1 fig. For sale by the Superintendent of Documents, U.S. Government Printing Office. Washington, D.C. 20402

382. Fishery puhlications, calendar year 1966: Lists and indexes. By Mary Fillen Engett and I eee C. Thorson. July 1973, iv + 19 p., 1 fig. For sale hy the Superintendent of Documents, U.S. Government Printing Office. Washington, D.C. 20402.

33:3. Fishery puhlications, calendar year 1965: Lists and indexes. By Lee C. Thursun and Marv Ellen Engett. July 1973, iv +12 p., 1 fig. For sale hy the Superintendent of Documents. U.S. Government Printing Office, Washington. D.C. 20402.

384. Marine flora and fauna of the northeastern United States. Higher plants of the marine fringe. By Edwin T. Moul. September 1973, iii +60 p. 109 figs. For sale hy the Superintendent of Documents, U.S. Govern. ment Printing Office, Washington. D.C. 20402.

385. Fishery publications, calendar year 1972: Lists and indexes. By Lee C. Thorson and Mary Ellen Engett. November 1973, iv +23 p., 1 fig. For sale by the Superintendent of Documents. U.S. Government Printing Office. Washington, D.C. 20402.

386. Marine flora and fauna of the northeastern United States. Pyc. nogonida. By Lawrence R. MicCloskey. September 1973, iii + 12 p. l 1 fig. For sale hy the Superintendent of Documents. L'.S. Government Printing Office, Washington, D.C. 20402 .

387. Marine flora and fauna of the northeastern United States. Crustacea: Stomatopoda. B* Raymond B. Manning. February 1974, iii + 6 p., 10 figs. For sale by the Superintendent of Documentr, L'.S. Government Printing Office, Washington. D.C. 20402 


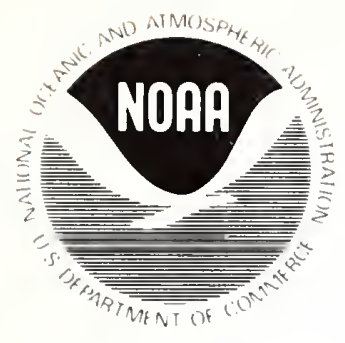

NOAA Technical Report NMFS Circular 417

Guide to the Identification of Genera of the Fish Order Ophidiiformes With a Tentative Classification of the Order

Daniel M. Cohen and Jorgen G. Nielsen

December 1978

U.S. DEPARTMENT OF COMMERCE Juanita M. Kreps, Secretary National Oceanic and Atmospheric Administration Richard A. Frank, Administrator National Marine Fisheries Service 
The National Marine Fisheries Service (NMFS) does not approve, recommend or endorse any proprietary product or proprietary material mentioned in this publication. No reference shall be made to NMFS, or to this publication furnished by NMFS, in any advertising or sales promotion which would indicate or imply that NMFS approves, recommends or endorses any proprietary product or proprietary material mentioned herein, or which has as its purpose an intent to cause directly or indirectly the advertised product to be used or purchased because of this NMFS publication. 
Introduction

Materials and methods

Order Ophidiiformes

Key to suborders

Ophidioidei

Key to families

Carapidae

Key to subfamilies

Pyramodontinae

Key to genera

Pyramodon

Snyderidia

Carapinae

Key to genera

Carapus

Echiodon

Encheliophis

Onuxodon

Ophidiidae

Key to subfamilie

Brotulinae

Brotula

Brotulataeniinae

Brotulataenia

Ophidiinae

Key to tribes

Lepophidiini

Key to genera

Cherublemma

Genypterus

Lepophidium

Ophidiini

Key to genera

Chilara

Ophidion

Otophidium

Parophidion

Raneya

Neobythitinae

Key to tribes

Sirembini

Key to genera

Acanthonus

Dannevigia

Hoplobrotula

Sirembo

Tauredophidium

Xyelacyba

Neobythitini

Key to genera

Abyssobrotula

Alcockia

Barathrites

Barathrodemus

Bassobythites

Bassogigas 


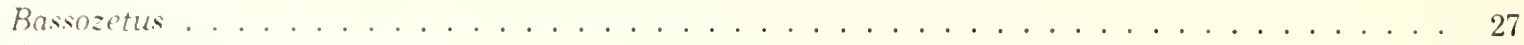

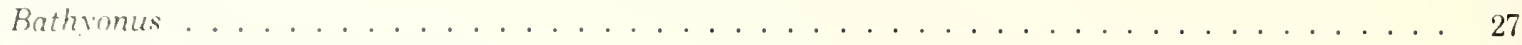

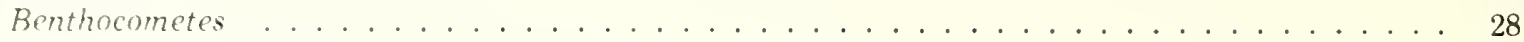

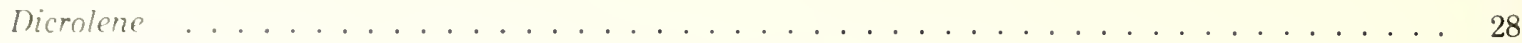

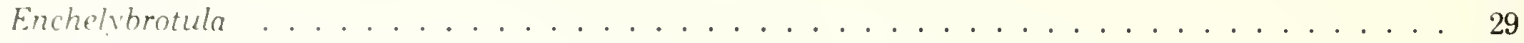

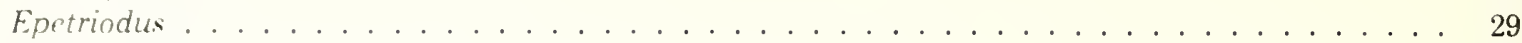

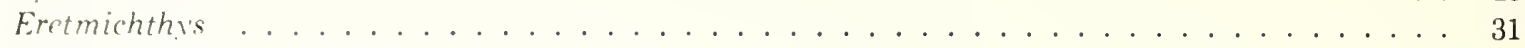

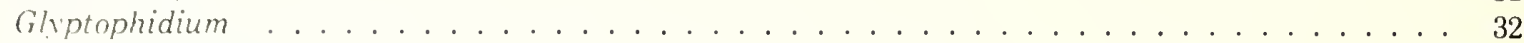

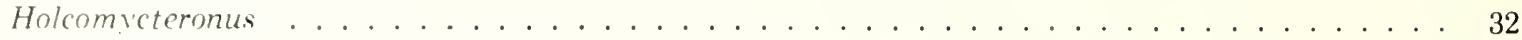

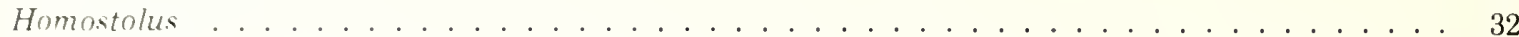

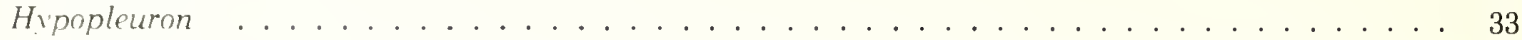

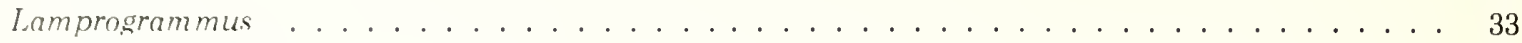

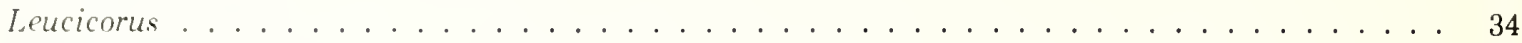

Luciobrotula . . . . . . . . . . . . . . . . . . . . . . . . . . 34

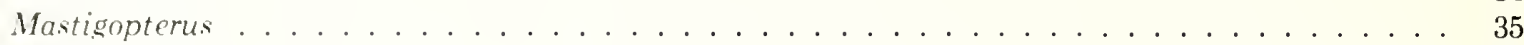

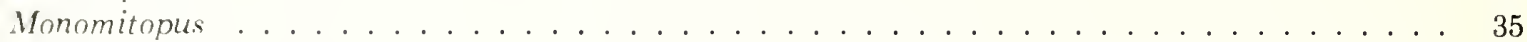

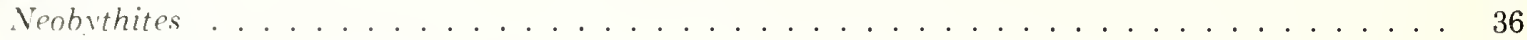

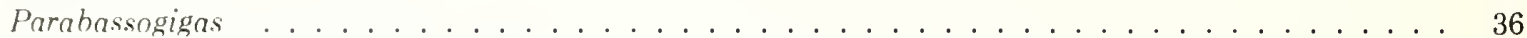

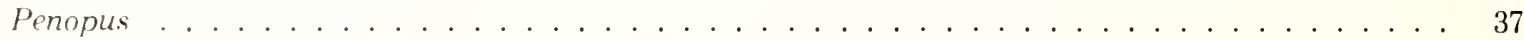

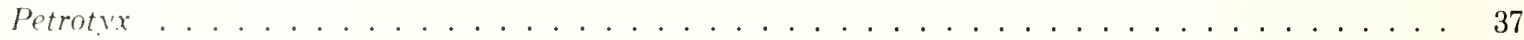

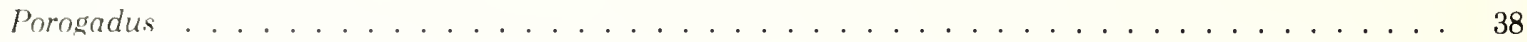

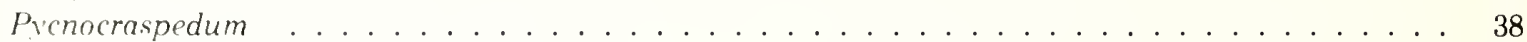

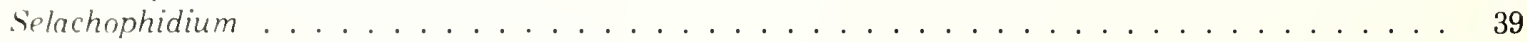

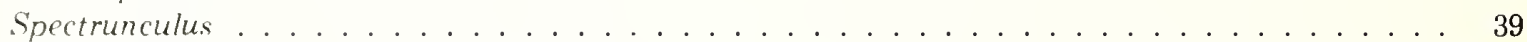

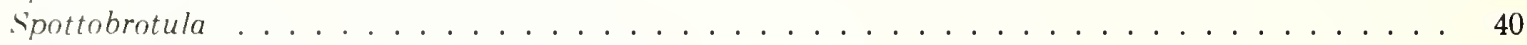

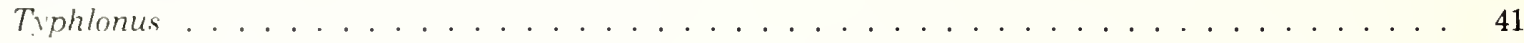

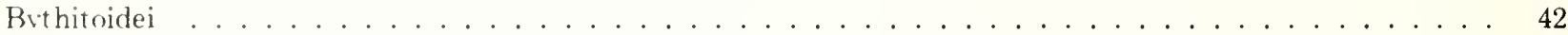

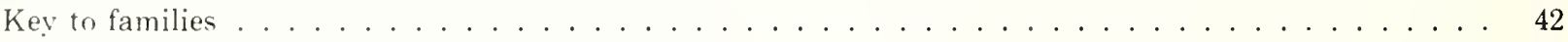

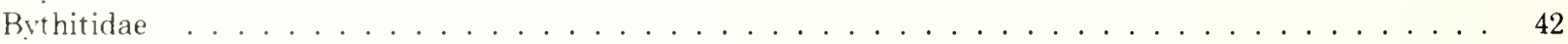

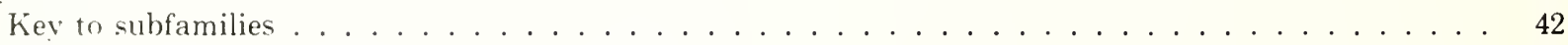

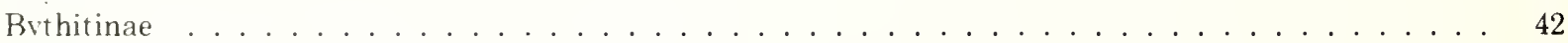

Kev to genera ....................................442

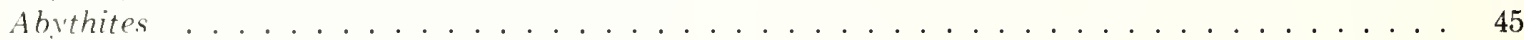

Bellottia ..................................445

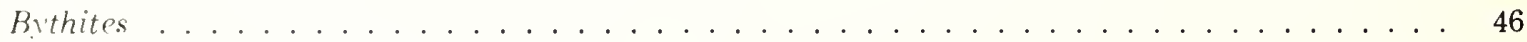

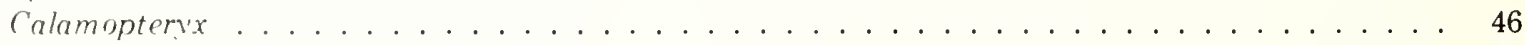

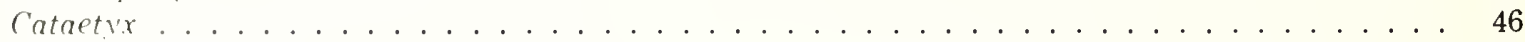

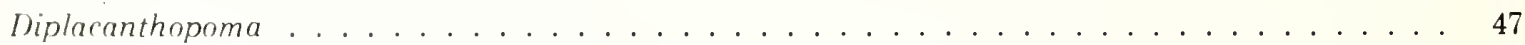

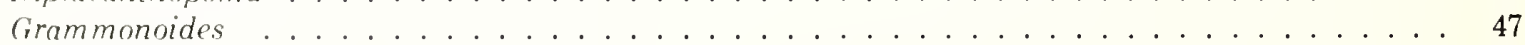

Hephthocara .....................................48

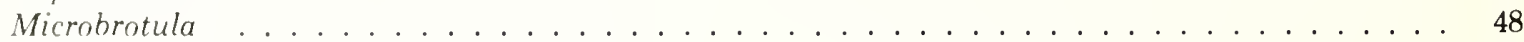

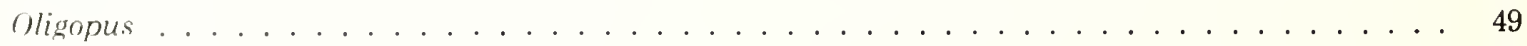

Propteridium ... . . . . . . . . . . . . . . . . . . . . . . 49

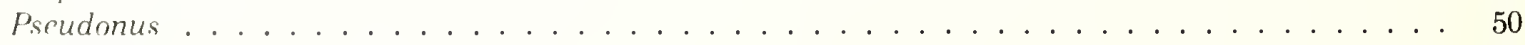

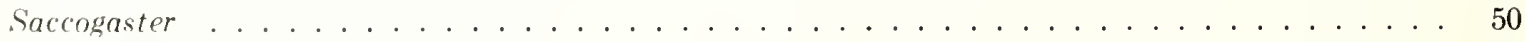

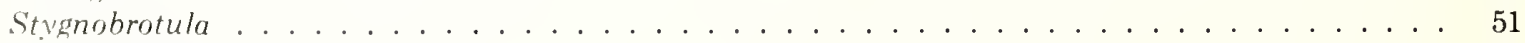

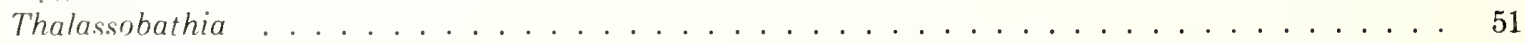

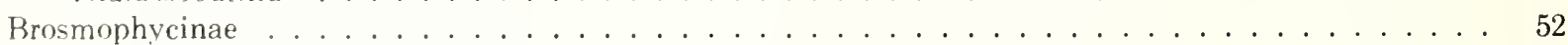

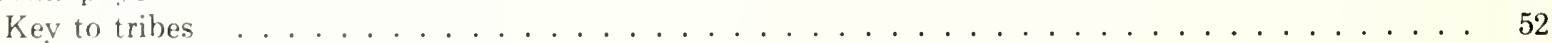

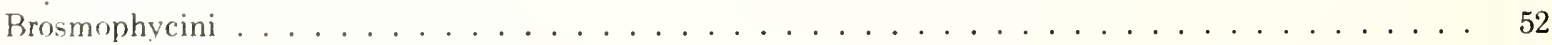

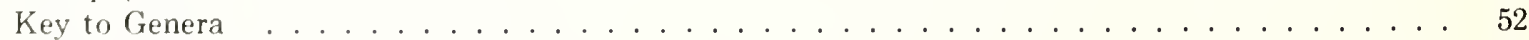

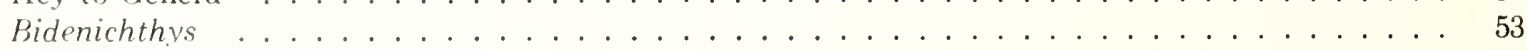

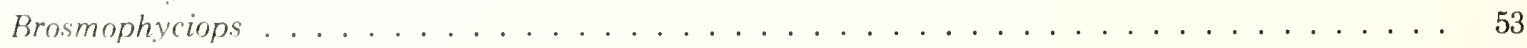

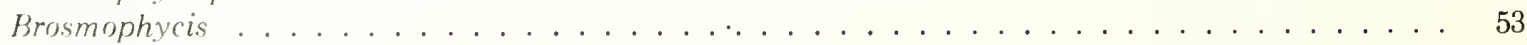

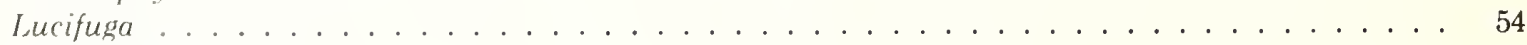

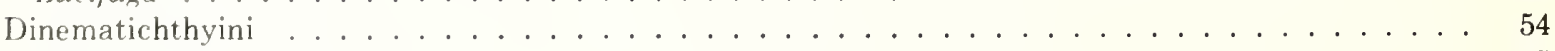

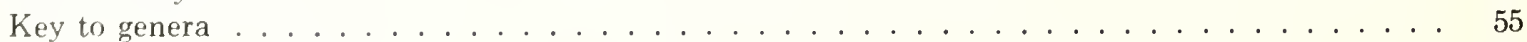

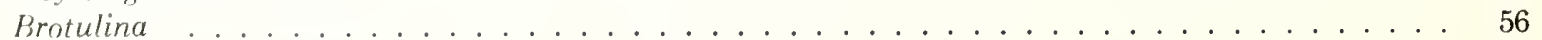

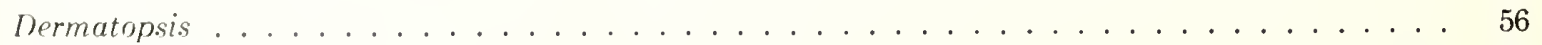

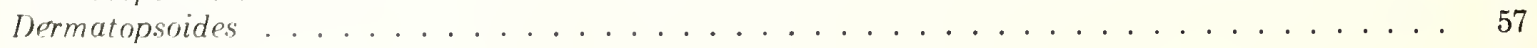




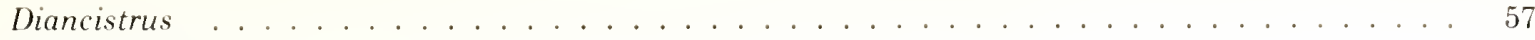

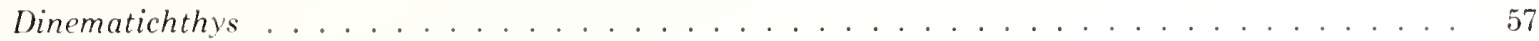

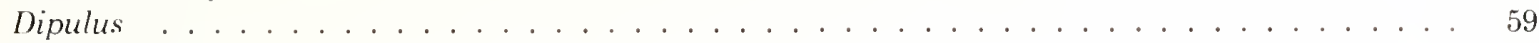

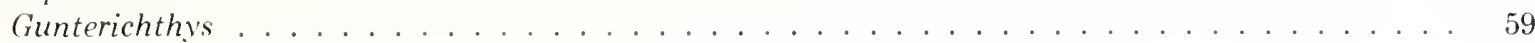

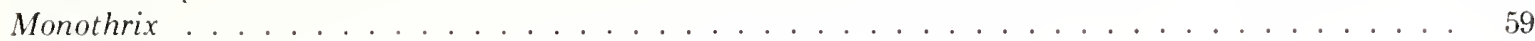

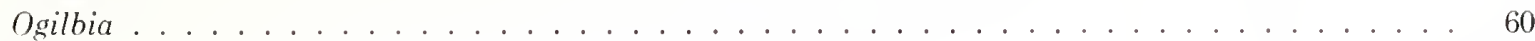

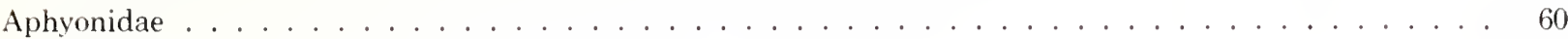

Key to genera . . . . . . . . . . . . . . . . . . . . . . 61

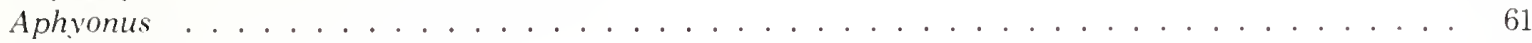

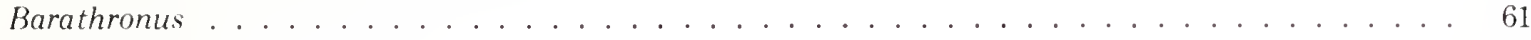

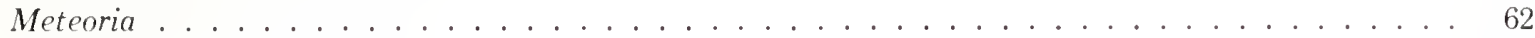

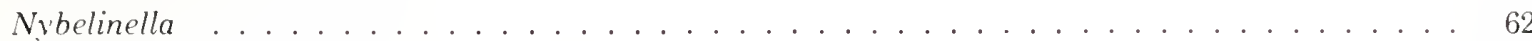

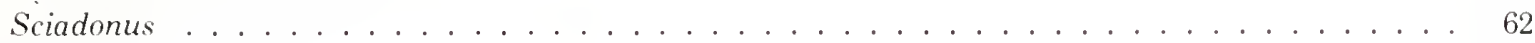

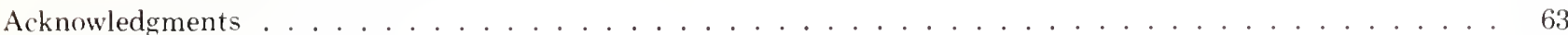

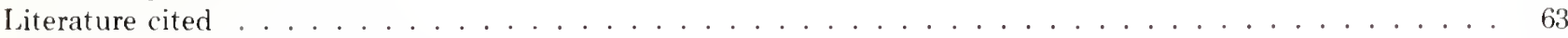

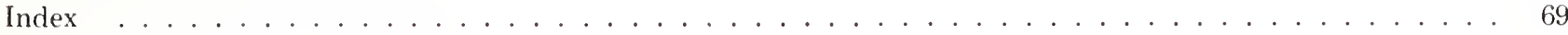

\section{Tables}

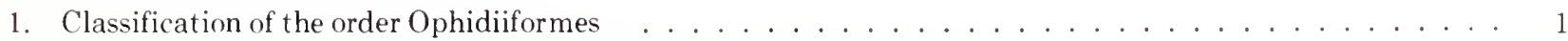

2. Counts and measurements in millimeters for Epetriodus freddyi . . . . . . . . . . . . . 30

\section{Figures}

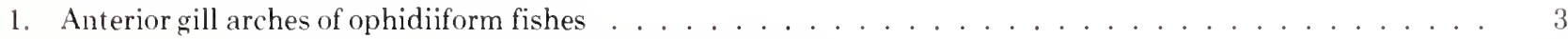

2. Dentition in the floor of the mouth of Holcomycteronus . . . . . . . . . . . . . . . 4

3. Diagrams of cross sections through the ventral fins of three kinds of ophidiiform fishes . . . . . . . 4 4

4. Position of anterior nostril in two suborders of ophidiiform fishes . . . . . . . . . . . . . 5

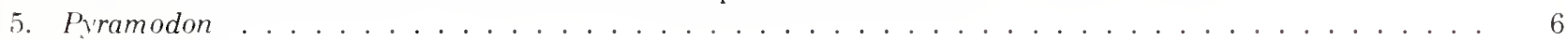

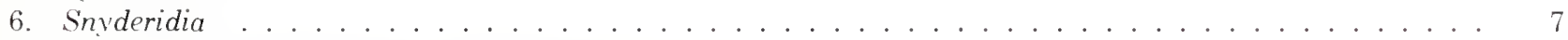

7. Condition of maxillary in two genera of carapine fishes . . . . . . . . . . . . . 7

8. Upper and lower jaw teeth in Onuxodon . . . . . . . . . . . . . . . . . . . . . 8

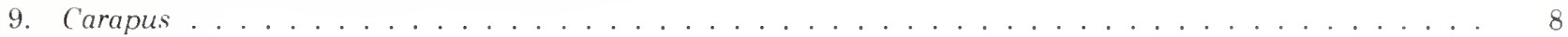

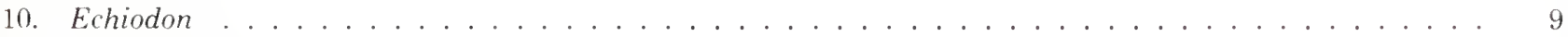

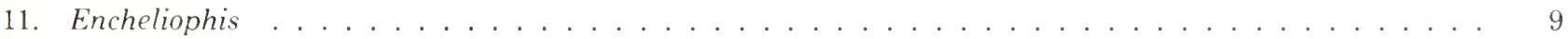

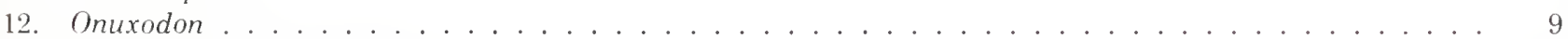

13. Brotulataenia body scales . . . . . . . . . . . . . . . . . . . . . . . 10

14. Ventral fin support in two subfamilies of ophidiid fishes . . . . . . . . . . . . . . . . 11

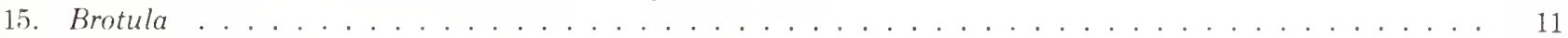

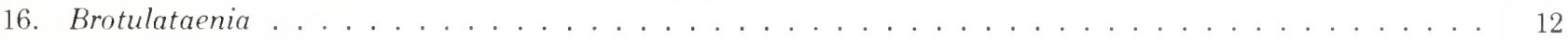

17. Ophidiini body scales . . . . . . . . . . . . . . . . . . . . . . . . 12

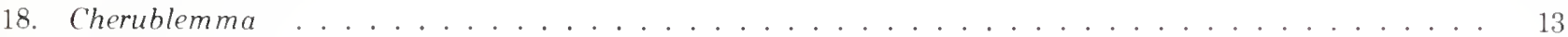

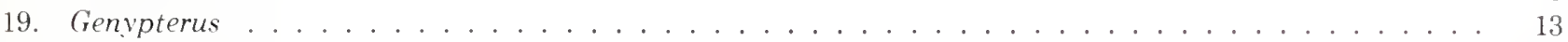

20. Lepophidium . . . . . . . . . . . . . . . . . . . . . . . . . . . . . . 14

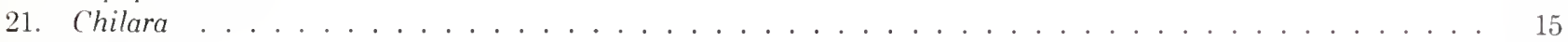

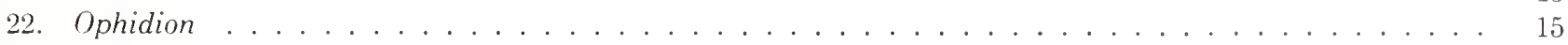

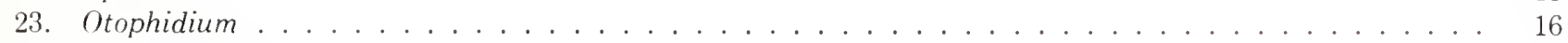

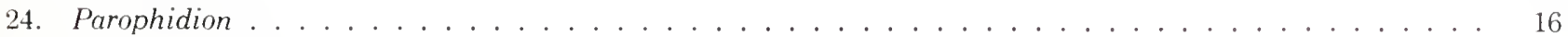

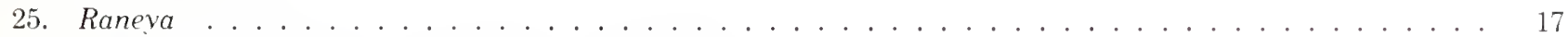

26. Ventral fin insertions in two genera of Sirembini . . . . . . . . . . . . . . . . 17

27. Acanthonus . . . . . . . . . . . . . . . . . . . . . . . . . 18

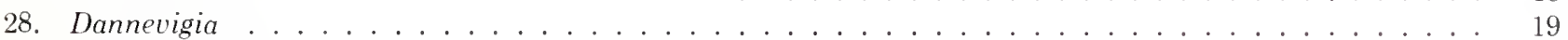

29. Hoplobrotula . . . . . . . . . . . . . . . . . . . . . . . . . . . . . . 19

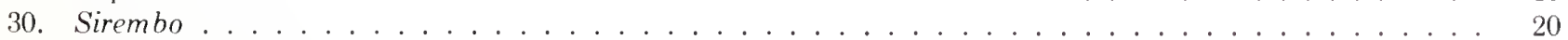

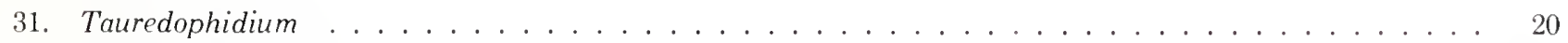

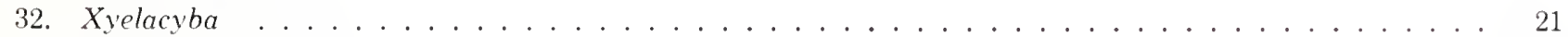

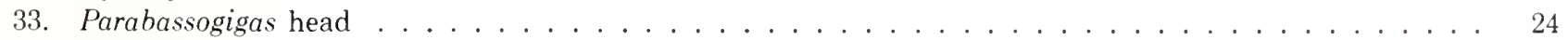

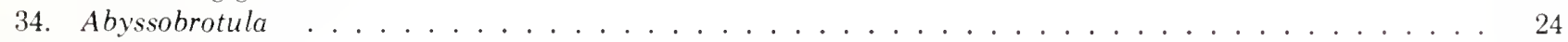

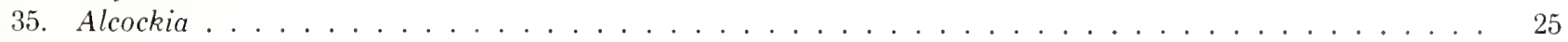




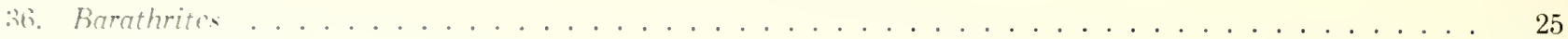

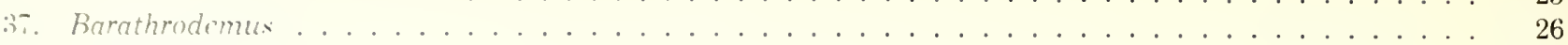

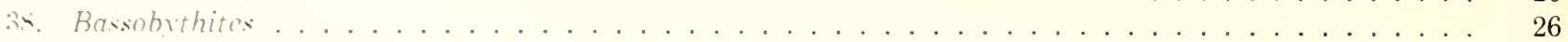

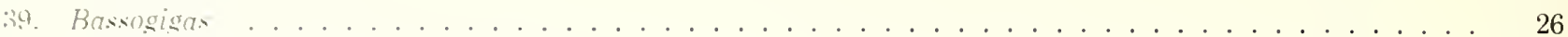

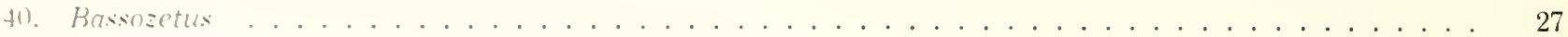

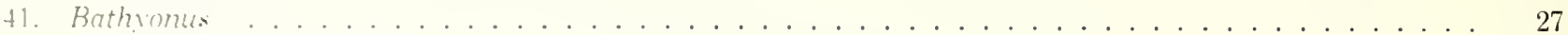

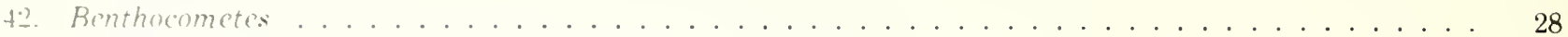

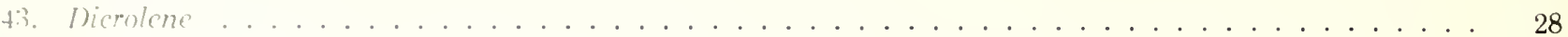

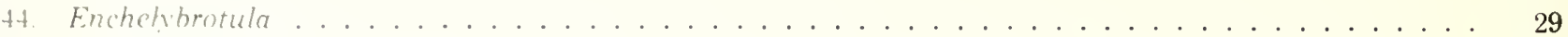

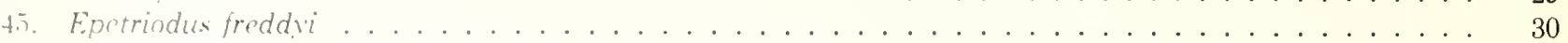

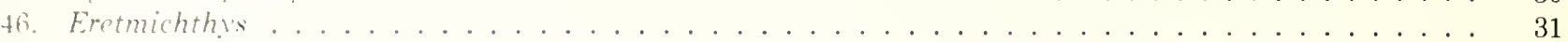

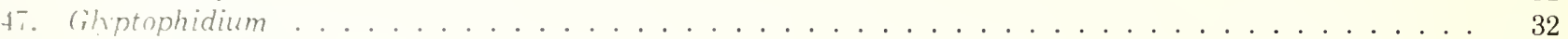

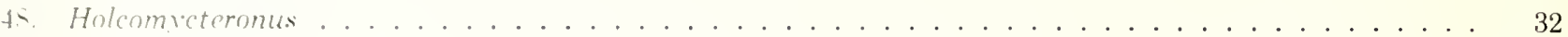

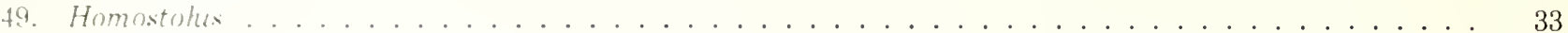

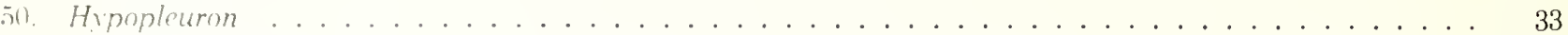

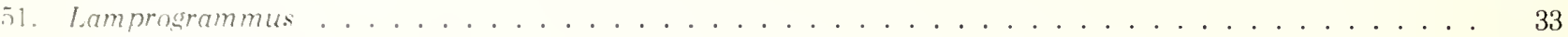

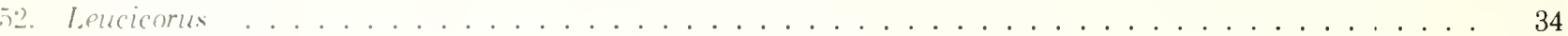

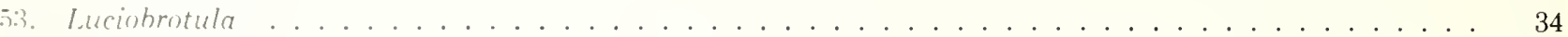

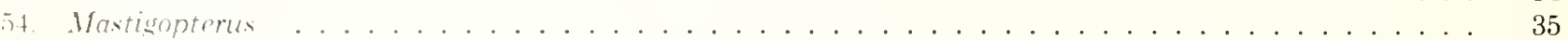

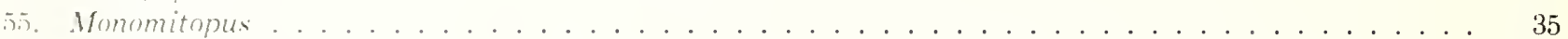

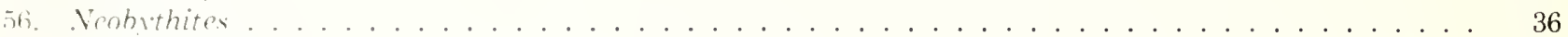

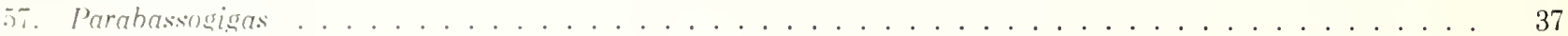

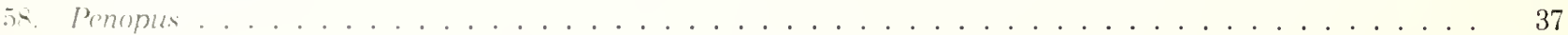

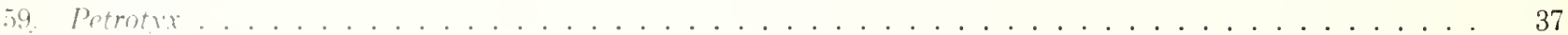

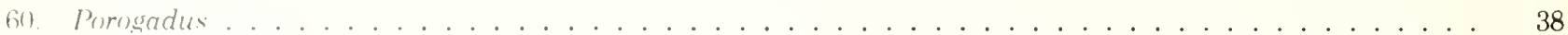

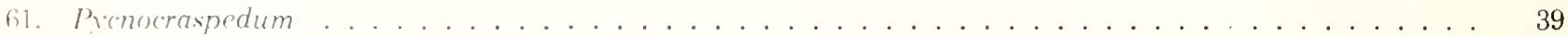

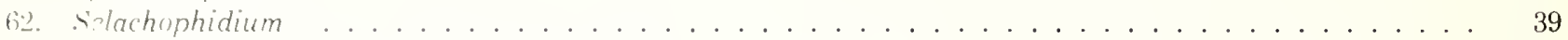

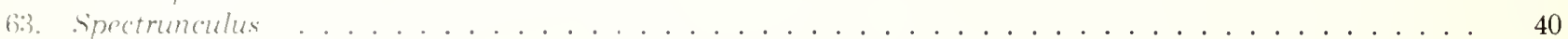

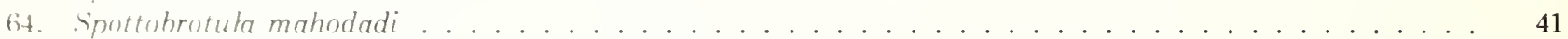

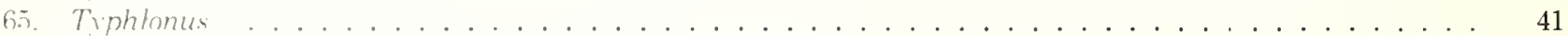

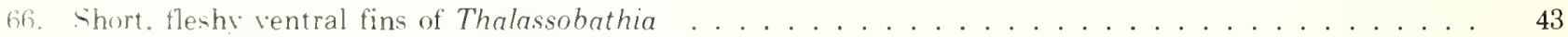

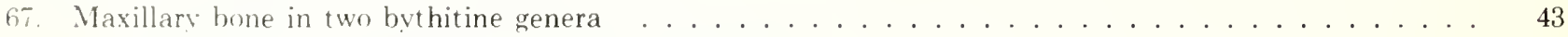

6x. Prominent skin flap on the head of Diplacanthopoma . . . . . . . . . . . . . . . . . . . . . . . . .

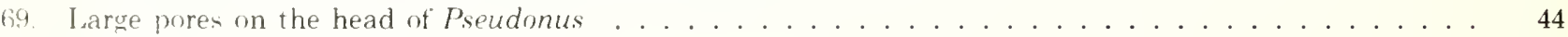

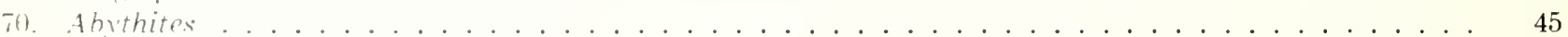

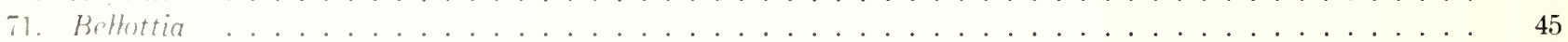

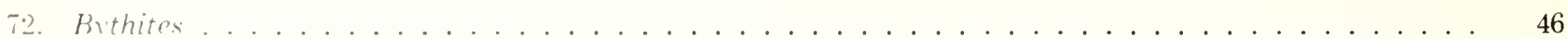

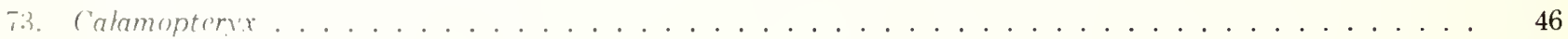

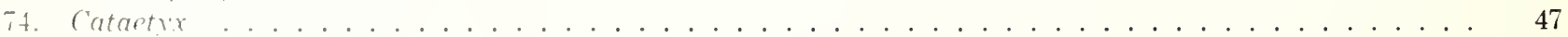

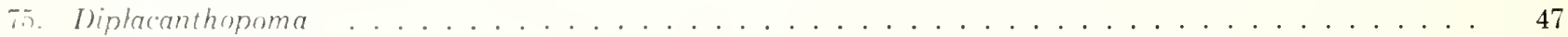

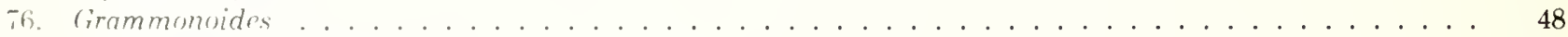

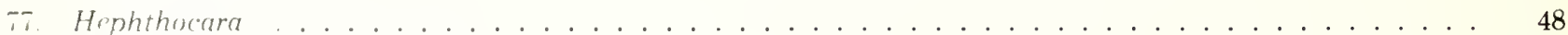

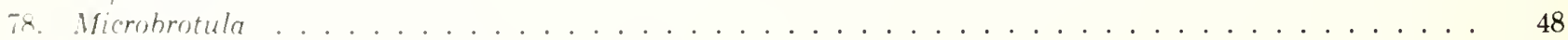

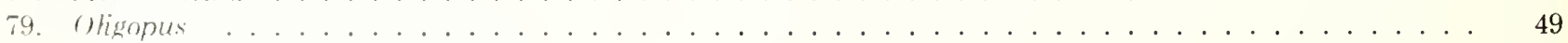

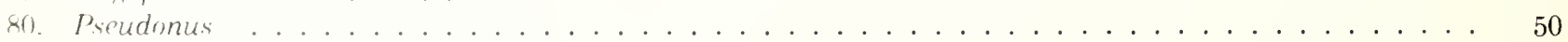

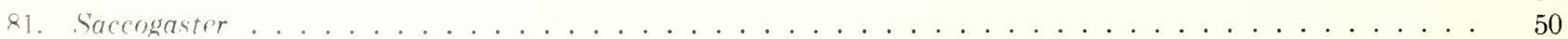

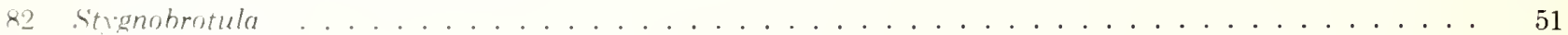

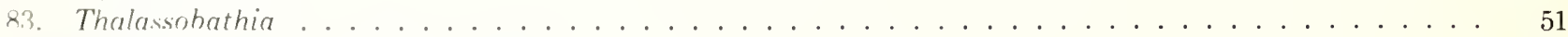

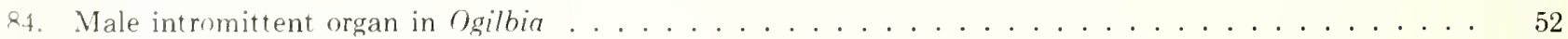

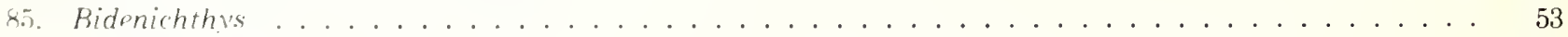

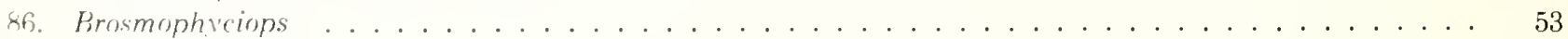

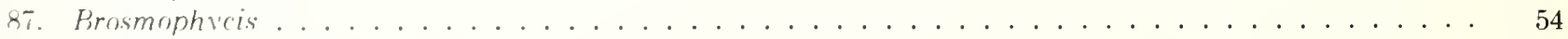

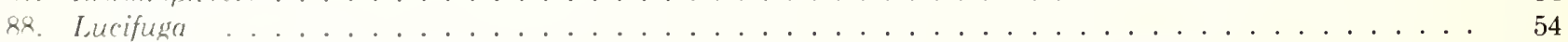

89. Head of Dinematichthys showing the anterior nostril placed high above the upper lip . . . . . . . 55

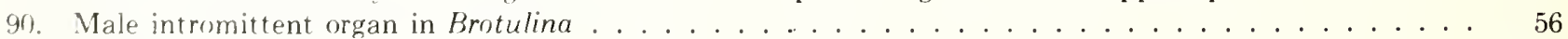

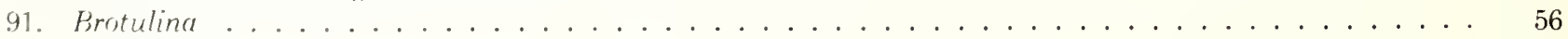

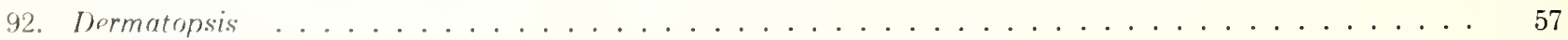

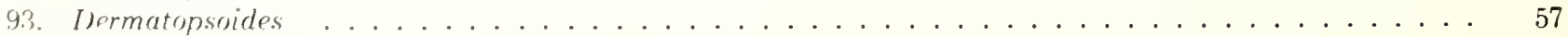

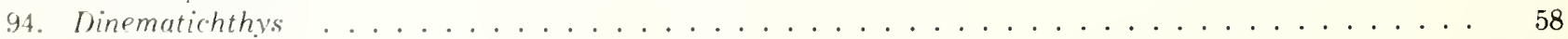

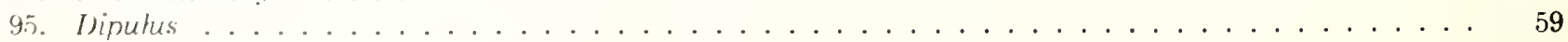




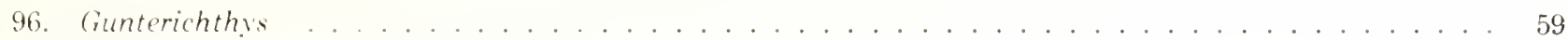

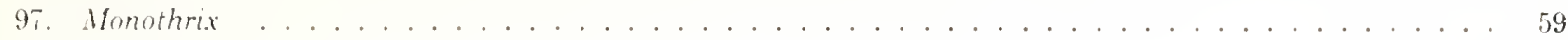

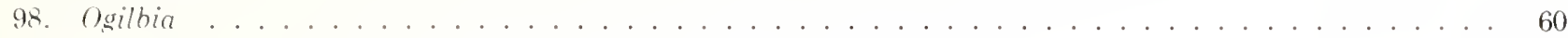

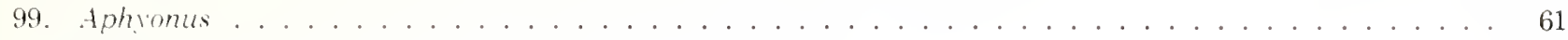

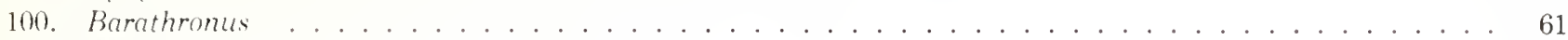

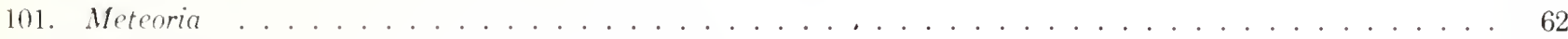

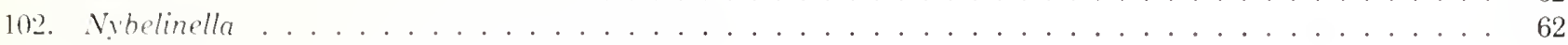

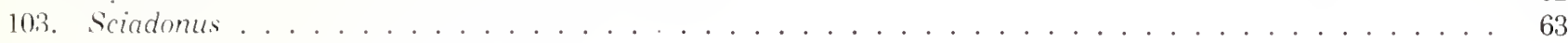


Digitized by the Internet Archive in 2013

http://archive.org/details/guidetoidentific00cohe 


\title{
Guide to the Identification of Genera of the Fish Order Ophidiiformes With a Tentative Classification of the Order
}

\author{
DANIEL M. COHEN ${ }^{1}$ and JØRGEN G. NIELSEN ${ }^{2}$
}

\begin{abstract}
Objectives of the paper are to provide dichotomous keys for the identification of ophidiiform genera. For each genus a brief account is presented including synonymy, a short diagnosis, a list of species, distribution, references, when possible comments on relationships, and for most an outline drawing.

The genera are organized into an hierarchical classification which divides them into two suborders, Ophidioidei, which contains oviparous fishes with a high anterior nostril, and Bythitoidei which contains viviparous fishes with a low anterior nostril.

Ophidioidei is divided into two families. Carapidae, with a vexillifer larval stage, has two subfamilies: Pyramodontinae with two genera and Carapinae with four. Ophidiidae has four subfamilies: Brotulinae, with a single genus; Brotulotaeniinae (new family) with a single genus; Ophidiinae, the cusk eels, with eight genera in two tribes; and Neobythitinae, with 38 genera (Epetriodus and Spottobrotula are new genera based on new species from the Indian Ocean) in two tribes.

Bythitoidei contains two families, one of which, Aphyonidae has five genera characterizcd by many ncotenic features. Bythitidae is divided into the free-tailed Brosmophycinae with 13 genera in two tribes and Bythitinae with 15 genera.
\end{abstract}

\section{INTRODUCTION}

The ophidiiform fishes comprise a diverse group containing approximately 135 nominal genera and between 300 and 400 species that dominate large areas of the floor of the deep sea and also live pelagically, on the continental shelf, in tropical reef areas, and even in estuarine and fresh waters.

There are so many species of these fishes and there is so little information on their anatomy that many years will pass before there is a comprehensive and well-documented study of their systematics. In order to facilitate such research, and also investigations on other aspects of the biology of ophidiiform fishes, we present in this paper keys to the genera, brief descriptions of each, and lists of included species. The keys are essentially updated versions of Norman's (1939) Synopsis of Oceanic Genera and its expanded successor (Norman 1966). Both of these works are essential references for anyone studying ophidiiform taxonomy but are outdated, covering literature no later than 1938.

The chief purpose of this paper is to distinguish genera from each other by means, whenever possible, of superficial and easily seen characters. For purposes of convenience we have clustered similar genera and similar assemblages of genera into a hierarchy of categories

'Systematics Laboratory, National Marine Fisheries Service, NOAA, Washington, D.C. 20560.

ZZoologiske Museum, Universitetsparken 15, DK2100, Copenhagen, Denmark.
(Table 1) that constitutes a classification of the order, one that varies in several respects from those in current usage. We do not here present this classification as a phylogeny. We believe, however, that the classification has good predictive value and will probably serve as a useful basis for a thorough phyletic study of the order.

Many species and several genera assigned to Ophidiiformes are based on fossil material, mostly otoliths. We have considered only those few based on remains adequate to place them in our classification, but we have reviewed names for possible instances of homonymy.

\section{MATERIALS AND METHODS}

The most important of earlier collections, upon which many names are based, are those taken by Blake and Albatross and described by Goode and Bean, Garman, and Smith and Radcliffe and kept in Washington, D.C., in the U.S. National Museum of Natural History and in Cambridge, Mass., in the Harvard University Museum of Comparative Zoology; those caught by Challenger and reported upon by Günther and stored in London in the British Museum (Natural History); and those trawled by Investigator and studied by Alcock and maintained in Calcutta in the Indian Museum and in London. In Copenhagen and Washington, D.C., we have had at our disposal the rich collections taken more recently by Galathea, Oregon I, Oregon II, and various reef expeditions. Other collections of ophidiiform fishes are widely dispersed, and we have had access to most of them. 


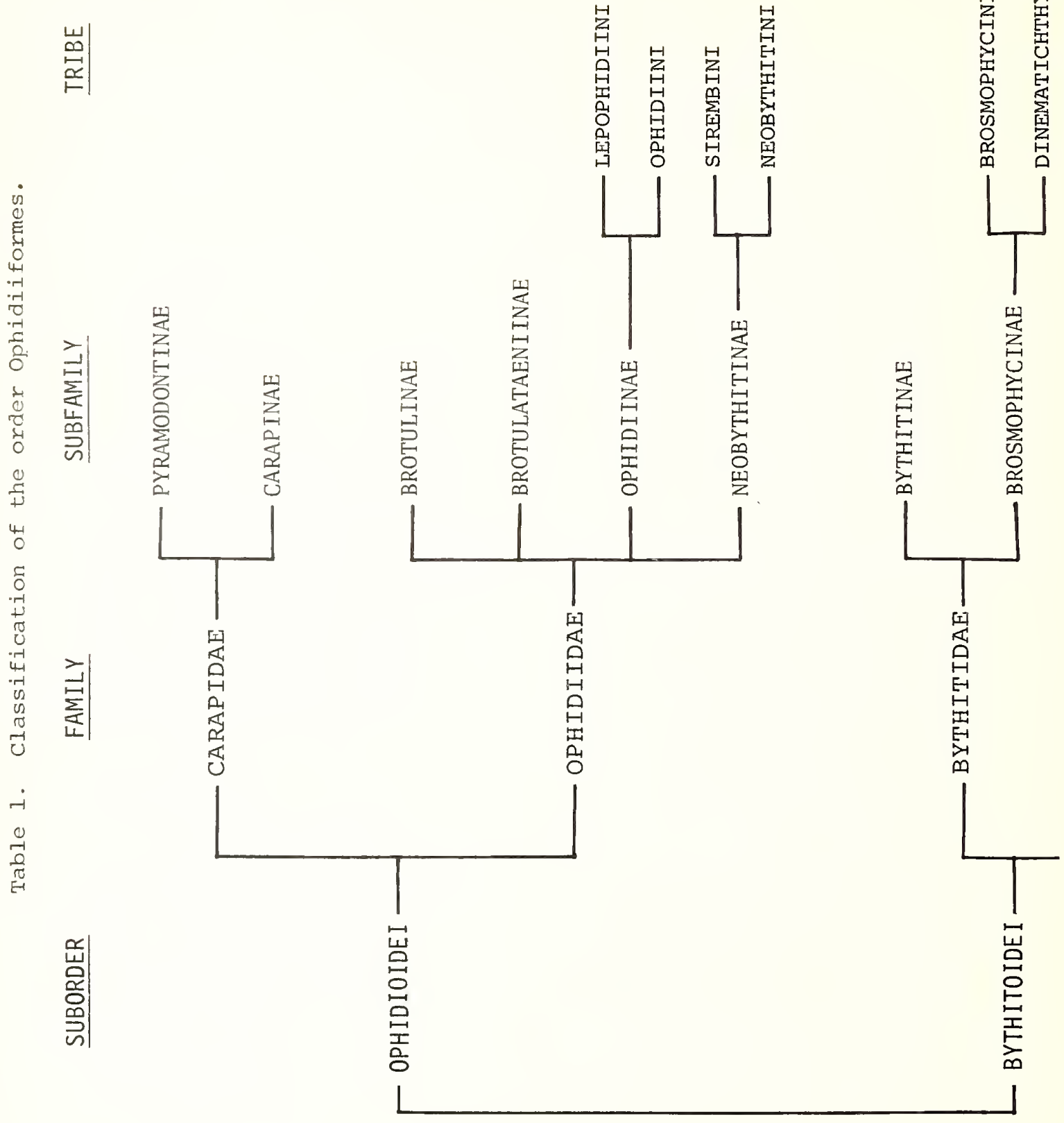


Species that we have examined are marked with an asterisk.

Descriptive terminology used in the keys and text is in most instances obvious or illustrated. Several characters however, require additional comment.

Branchiostegal rays. A useful but occasionally difficult character, as in some species they are covered with darkly pigmented or thick skin, which it may be necessary to strip away from the inner face of the branchiostegal membranes. The literature contains many inaccurate branchiostegal ray counts.

Caudal fin rays. The number of rays in the caudal fin is a useful taxonomic character. The count is relatively easy to determine with transmitted light; in many species the rays may be counted from X-ray photographs. For free-tailed genera, counts include all rays in the caudal fin. The equivalent count in genera with confluent median fins consists of those rays supported by the hypurals, including in some the parhypural as well, although it does not always support a ray. Epurals are rarely sufficiently well-developed to serve as fin ray supports. In a very few instances, Brotula for example, the caudal fin skeleton is more complex with rays being carried by a parhypural, two free hypural elements, and two epurals. In fishes with free or joined tails, care must be taken to distinguish between normal and regenerated tails.

Gill rakers. We have used the terms "long" or "developed" interchangeably throughout this paper to describe one kind of gill raker. Nearly all ophidiiform fishes have low pads or short tubercles at the anterior ends of the upper and lower arms of the first arch, and longer structures, ranging from short knobby tubercles to elongate, compressed, lathlike rakers closer to the angle of the arch, sometimes interspersed with pads or shorter tubercles. In a few species pads or short tubercles grade gradually into developed (= long) rakers. In most however, the two kinds are quite distinct, regardless of their absolute sizes (Fig. 1). A few species completely lack developed rakers.

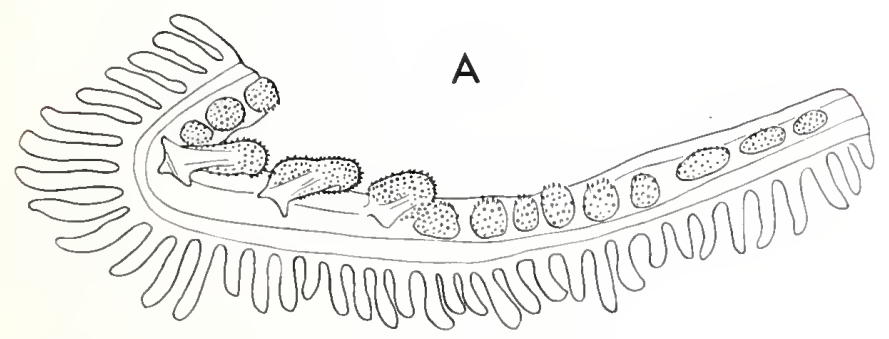

Intromittent organ. Bythitoid fishes have a variously developed intromittent organ in the male. In most of these fishes the organ consists of a fleshy hood, a penis, and fleshy ridges, lobes, or flaps. In the genera that we include in the tribe Dinematichthyini there are one or more pairs of stiff, ossified lobes or prongs, two types of which are illustrated in this paper (Figs. 84,90). We call these structures pseudoclaspers, following the terminology of Suarez (1975) who has presented a detailed description of the genitalia of Ogilbia cayorum and cited pertinent literature.

Maxillary sheath. In some genera the posterior part of the maxillary is sheathed by a fold of skin that covers, to a greater or lesser extent, the dorsal part of the bone; in the carapine genus Encheliophis the maxillary is bound by skin to the side of the head. In other genera the posterodorsal part of the maxillary is completely free.

Rocker bone. Several genera of Ophidinae and Carapidae have a prominent, median, bean-shaped bone (apparently part of a sound producing mechanism) associated with the anterior end of the swim bladder and located beneath the anterior several vertebral centra. This structure cannot be seen exteriorly but is visible on $\mathrm{X}$-ray photographs. It has been described most recently by Courtenay and McKittrick (1970), who called it a rocker bone and by Svetovidov (1961), who called it a cuneiform bone.

Teeth. Many genera have jaw teeth that we call granular. They are minute, densely distributed, and rather blunt tipped. A patch of these teeth is like sandpaper to the touch. Other genera have larger, more widely distributed, needlelike teeth of varying sizes. Some genera have both types. In several genera the type of dentition may be related to degree of maturity and perhaps sex.

Most genera of Ophidioidei have one or more median basibranchial patches of granular teeth, which may vary in size and shape. Many ophidiiform genera have one pair of patches of granular teeth on the basibranchial. A

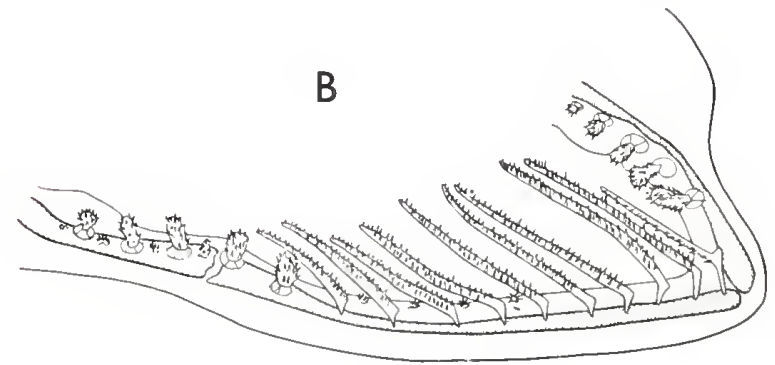

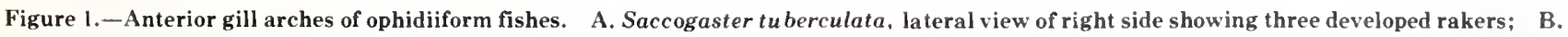
Leucicorus atlanticus, lateral view of left side showing 10 developed rakers. 
patch of gramular teeth is usually present at the base of each fitth gill arch and should not be confused with basibranchial teeth (Fig. 2).

lintral fin rass. Ophidiiform fishes with ventral fins, which includes most of them, have either one or two soft rays in each: a short hidden spine which is present in many is not included in our counts. We have checked many species by examining alizarin-stained specimens, dissecting fins. or examining cross sections of fins. We have observed the following conditions, which are shown in diagrammatic cross sections in Figure 3: a single ray in each fin, the two halves bound together; two rays in each fin. the rays separate from each other for all or part of the length of the fin. but the two halves of each ray bound together: and two rays in each fin, the rays bound together for the entire length of the fin. There are many incorrect statements in the literature; a common one is that each fin has a single ray, the two halves of which are separate: we have never observed this condition. In some species, however, the two halves of a ray may be of unequal lengths.

lertehrae. In those few instances in which we give the total number of vertebrae, the ural centra are not included.

Vexillifer stage. One of the planktonic, preadult stages of most, perhaps all carapids. It is characterized by the presence of a long filamentous and usually ornamented structure placed anterior to the dorsal fin, which

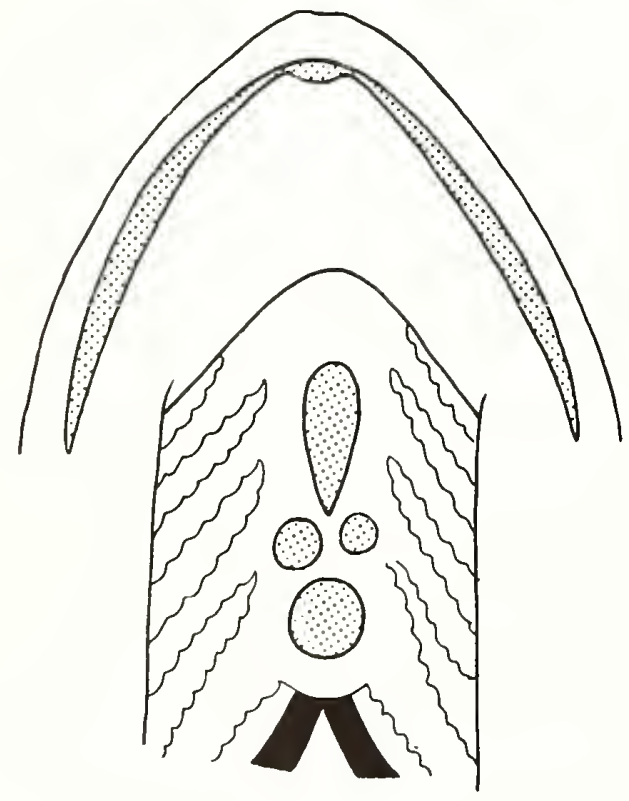

Figure 2.- Dentition in the floor of the mouth of Holromieleronus. silippled a reas include lwo median basihranehial tooth palches. one pair of basihranchial lowlh palehes. and the dentaries. The dark areas are the hases of the fifih arehes. is called the vexillum. It has been described and figured by many authors; see for example Strasburg (1965).

The keys in this paper are based chiefly on adults. They will identify earlier stages with various measures of success.

\section{ORDER OPHIDIIFORMES}

It is not now possible to give a diagnosis of the order. The following characters, taken in combination, should help to identify a fish as an ophidiiform.

1) Ventral fins with one or two soft rays in each or completely absent.

2) Ventral fins inserted at about the level of the preopercle or farther anterior.

3) Ventral fins relatively close together (in all but Tauredophidium).

4) Dorsal and anal fins with long bases, extending to and often joined with the caudal fin.

5) Fin ravs soft (although small pelvic spines are present in some genera).

6) Dorsal and anal fin pterygiophores more numerous than adjacent vertebrae.

7) Nostrils paired on each side of head.

There has never been complete agreement among ichthyologists as to the phyletic relationships, the constituents, or the taxonomic rank of the Ophidiiformes. It is not our purpose here to treat these topics in depth; however, a few brief comments are in order.

Two quite different opinions are current concerning the relationships of these fishes. A classification that relates ophidioids with gadoids and zoarcoids has been revived by Rosen and Patterson (1969), who merge all three in an expanded order Gadiformes, which they place in the superorder Paracanthopterygii, a group that they classify as distinct from and parallel with Acanthop-
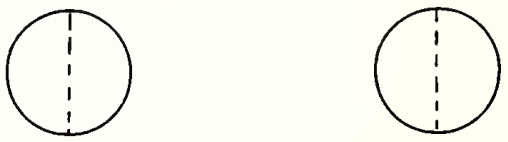

A
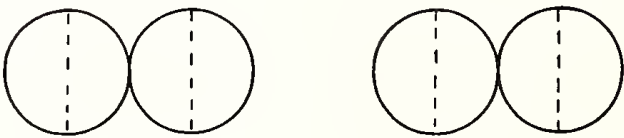

B
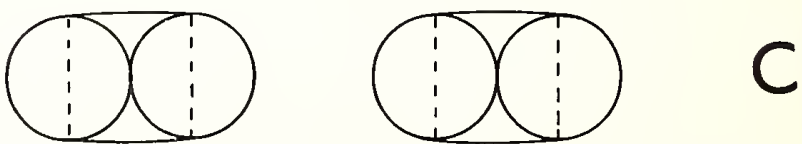

Figure 3.-1)iagrams of cross sections through the ventral fins of three kinds of ophidiiform fishes. the dotled line in each separates the Iwo halves of a single ray. A. One ras in each fin. B. Two separate rass in each fin. ('. Two joined rass in each fin. 
terygii. Previously unknown information on the pattern of the ramus lateralis accessorius nerve (Freihofer 1963; with additional data given in 1970) provide strong support for Rosen and Patterson's classification.

On the other hand, a perciform origin for the ophidioids was defended by Gosline (1968), who forwarded the enigmatic Australian freshwater genus Gadopsis as a link with more typical advanced spiny rayed fishes. Similarities in nerve patterns of ophidioids and gadoids were suggested as being instances of convergence in bottom living fishes by Gosline (1968), Fraser (1972), and Marshall and Cohen (1973). Additional support for the hypothesis of perciform relationships of ophidioids and their separation from gadiforms was given by studies on the molecular genetics of the lactate dehydrogenase C4 isozyme by Shaklee et al. (1973) and Shaklee and Whitt. ${ }^{3}$

In somewhat of a middle course the ophidioids were described as more primitive than the Perciformes and close to but distinct from Gadiformes by McAllister (1968).

Ophidioid fishes are so many, diverse, and poorly known that few of the current generalizations about the group are sufficiently well founded to serve as bases for resolving the question as to its phyletic affinities. We separate ophidiiform from gadiform and zoarcoid fishes for reasons presented by Fraser (1972), Marshall and Cohen (1973) and Shaklee and Whitt (see footnote 3). Most previous workers have treated the ophidiiforms as a suborder. We follow Mead et al. (1964), McAllister (1968), and Fraser (1972) in according them ordinal rank, not least of all because given current uncertainty as to

'Shaklee, J. B., and G. S. Whitt. 1975. A reassessment of the interrelationships of gadiform fishes based on the analysis of biochemical characters. American Society of Ichthyologists and Herpetologists, Abstracts, Fifty-fifth Annu. Meet., p. 115. their placement, an order seems more easily movable baggage than does a suborder. We exclude Gadopsis from the group, though without prejudice as to its affinities; both Gosline (1968) and Rosen and Patterson (1969) have described numerous differences, which seem to us of sufficient magnitude to warrant this action.

The position of the ventral fins has been used by most ichthyologists as a primary character for distinguishing ophidiiform families. As a single character at such a level it is not a reliable indicator of relationships, as the ventrals may be in quite different positions in such obviously related genera as Tauredophidium and Xyelacyba, or even within a genus such as Acanthonus (Cohen 1961).

Mode of reproduction is a far more fundamental character in ophidiiform fishes, and we use it to delimit two suborders, one oviparous and the other viviparous.

Could viviparity have arisen more than once in ophidiiform fishes, as apparently it has done in other orders? Nearly all viviparous ophidiiforms have another specialized character, the position of the anterior nostril immediately above the upper lip. Such a combination of characters suggests a natural assemblage. However, the position of the anterior nostril is variable in the small assemblage of neotenic genera classified as the family Aphyonidae (Nielsen 1969) and is slightly to considerably above the upper lip in the shallow-water tropical reef dwelling genera Dinematichthys and Stygnobrotula and the pelagic Thalassobathia.

In contrast, most genera of oviparous ophidiiform fishes have the anterior nostril rather high above the upper lip; some cusk eels are exceptional in this respect in having the nostril low. Although there is not complete correspondence between position of the anterior nostril and mode of reproduction, character states do coincide in more than $90 \%$ of the genera and hence are useful to the taxonomist.

\section{KEY TO SUBORDERS}

1a. Oviparous, males lacking a developed external intromittent organ. Anterior nostril well above upper lip (Fig. 4a) in most (variable in some cusk eels). Median basibranchial tooth patches present or absent. Ventral fins at about the level of the preopercle or farther anterior in position, when present. Caudal fin usually present and connected with dorsal and anal fins . . . . . Ophidioidei

1b. Viviparous, males with variously developed external intromittent organ. Anterior nostril immediately above upper lip (Fig. 4b) in most (variable in Aphyonidae and a few bythitid genera). Median basibranchial tooth patches absent. Ventral fins at about the level of the preopercle in position, when present. Caudal fin connected with dorsal and anal fins or free . . . . . . . . . Bythitoidei
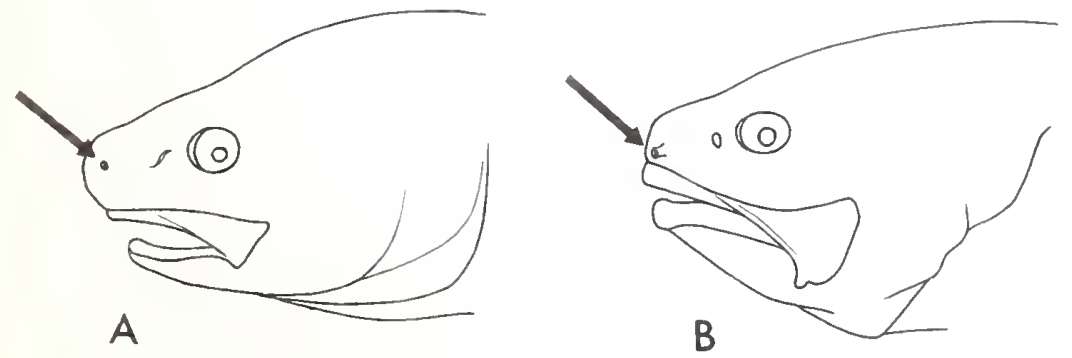

Figure 4.-Position of anterior nostril in two suborders of ophidiiform fishes. A. Ophidioidei, high on the snout; B. Bythitoidei, low on the snout. 


\section{SUBORDER OPHIDIOIDEI}

As presently reconstituted this group includes the following oviparous fishes.

The pearlfishes, mostly inquiline in habit, are considered a subfamily of Carapidae; a second subfamily includes the probably free-living Pyramodon and Snyderidia.

The cusk eels proper are a small group of genera that many ichthyologists have considered to be a separate family, Ophidiidae: we treat them as a subfamily of an expanded Ophidiidae.

Brotula is placed in a monogeneric subfamily of Ophidiidae.

The aberrant pelagic Brotulotaenia is given subfamilial status within Ophidiidae.

A great host of genera, formerly lumped with many viviparous genera in the family Brotulidae, are here grouped together as the subfamily Neobythitinae of Ophidiidae.

\section{Key to Families of Ophidioidei}

1a. Supramaxillary a bsent. Anal fin rays longer than opposing dorsal fin rays . . . . . . . . . Carapidae

1b. Supramaxillary present. Dorsal fin rays usually equal to or longer than opposing anal fin rays ...Ophidiidae

$$
\text { Carapidae Jordan and Fowler } 1902
$$

Supramaxillary absent. Anal fin rays longer than opposing dorsal fin rays. Scales absent. Vexillifer larval stage in most, possibly all species. For information and references on development and habits see Arnold (1956), Trott (1970), and Robertson (1975).

\section{KEY TO SUBFAMILIES OF CARAPIDAE}

1a. Pectoral fin rays $24-27$. Precaudal vertebrae $12-15 \ldots \ldots \ldots \ldots$. . . . . . . . . . . . . . . . . .

1b. Pectoral fin rays 20 or fewer. Precaudal vertebrae $17-27 \ldots \ldots \ldots \ldots$ Carapinae

\section{PYRAMODONTINAE SMITH 1955}

Pectoral fin rays 24 to 27. Precaudal vertebrae 12 to 15. Probably free-living as adults. The taxonomic history of the following two genera has been summarized by Robins and Nielsen (1970), whom we follow in recognizing them as constituting a carapid subfamily.

\section{Key to Genera of Pyramodontinae}

1a. Ventral fins present. Origins of dorsal and anal fins approximately opposite each other . . . . Pyramodon 1b. Ventral fins absent. Origin of dorsal fin anterior to origin of anal fin $\ldots \ldots \ldots$. . . . . Snyderidia

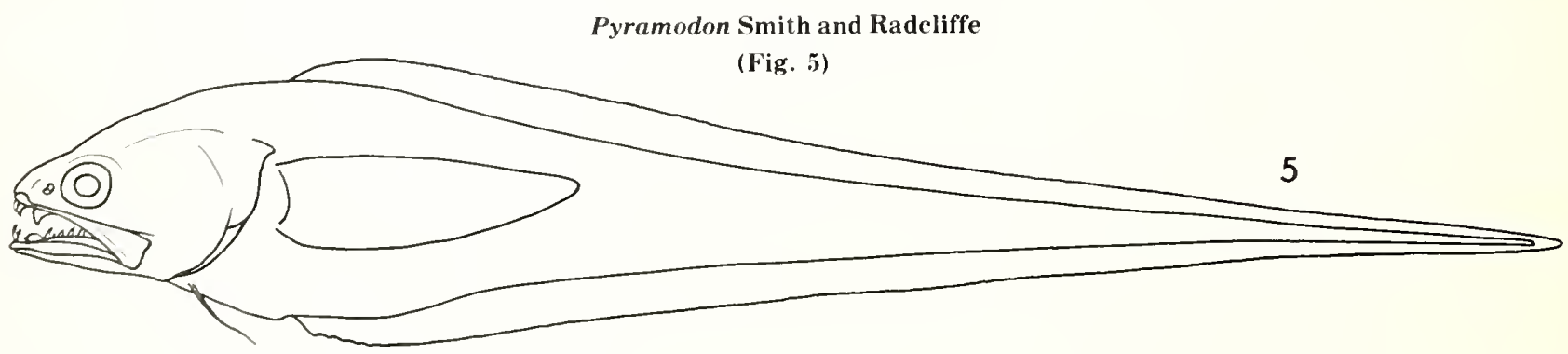

Pyramodon Smith and Radcliffe in Radcliffe (1913:175; type-species by original designation Pyramodon ventralis Smith and Radcliffe).

(ynophidium Regan (1914:16; type-species by monotypy Cynophidium punctatum Regan 1914).

Ventral fins present. Origins of dorsal and anal fins approximately opposite each other. See Smith (1955a) for a discussion of the genus and species. 
Taken on the shelf and upper slope.

South Africa, Japan, Indonesia, Australia, and New Zealand (as Snyderidia, see McCann 1972).

A single species, ${ }^{*} P$. ventralis Smith and Radcliffe in Radcliffe 1913.

\section{Snyderidia Gilbert}

(Fig. 6)

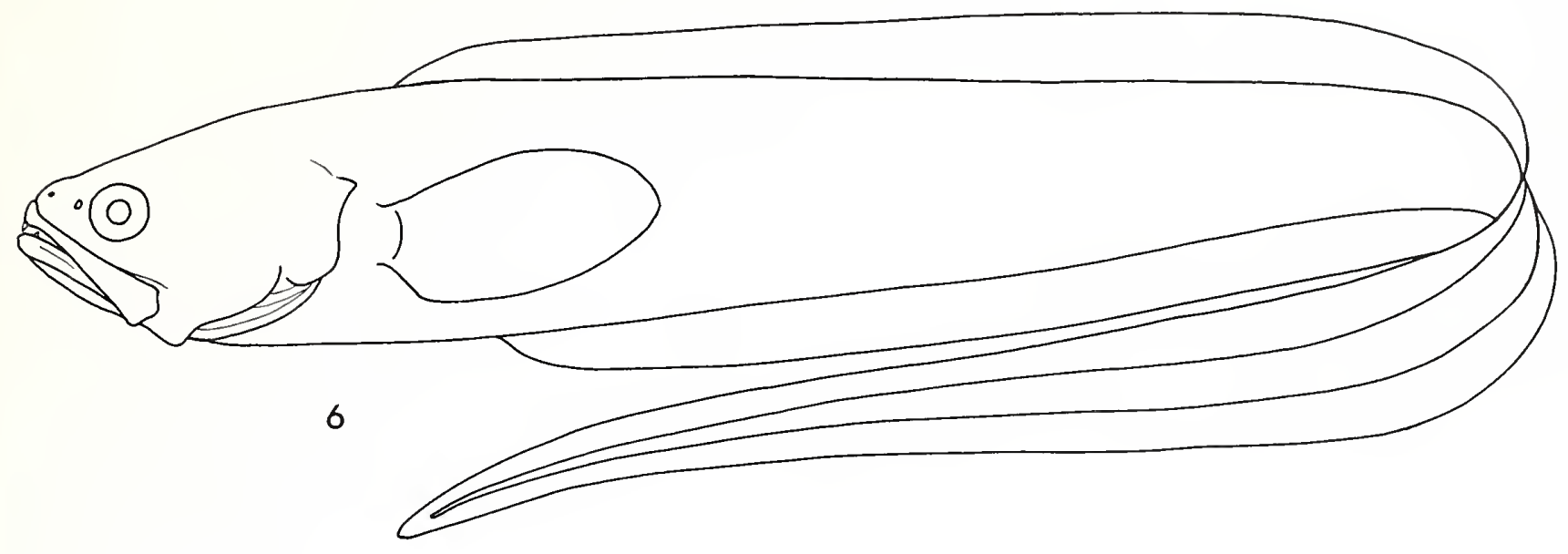

Snyderidia Gilbert (1905:654; type-species by monotypy Snyderidia canina Gilbert).

Ventral fins absent. Origin of dorsal fin anterior to origin of anal fin. The osteology of this genus has been discussed by Gosline (1960).

Adults have been taken on the shelf and upper slope. Larval stages are pelagic and resemble the early stages of carapines in bearing a vexillifer (Strasburg 1965).

Circumtropical.

Two nominal species: ${ }^{*} S$. bothrops Robins and Nielsen 1970, and ${ }^{*} S$. canina Gilbert 1905.

\section{Carapinae Jordan and Fowler 1902}

Pectoral rays 20 or fewer. Precaudal vertebrae 17 to 27.

The group has been revised by Arnold (1956). Consult his paper for references to citations in the following section, which are not included in the Literature Cited section of the present paper.

\section{Key to Genera of Carapinae}

1a. Teeth on jaws and palatine in a single row. Maxillary bound by skin to side of head (Fig. 7a) _. . Encheliophis

1b. Teeth on jaws and palatines in bands. Maxillary free $($ Fig. $7 b) \ldots \ldots \ldots \ldots$

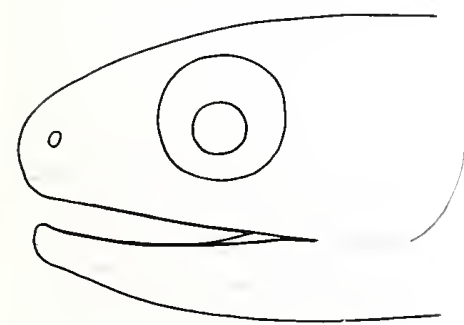

A

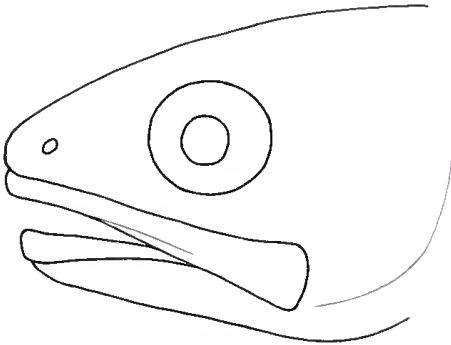

B
Figure 7.-Condition of maxillary in two genera of carapine fishes. A. Encheliophis, with the maxillary bound by skin to the side of the head; B. Carapus, with the maxillary free. 
2a. Teeth in upper and lower jaws in a continuous row with no pronounced gap near tip of jaw. En-

larged teeth at jaw tip present or absent . . . . . . . . . . . . . . . . . . . . . . Carapus

2b. Teeth in upper and lower jaw with a pronounced gap separating variously developed canines at

or near the jaw tip from a following band of smaller teeth (Fig. 8) . . . . . . . . . . . . . . . 3

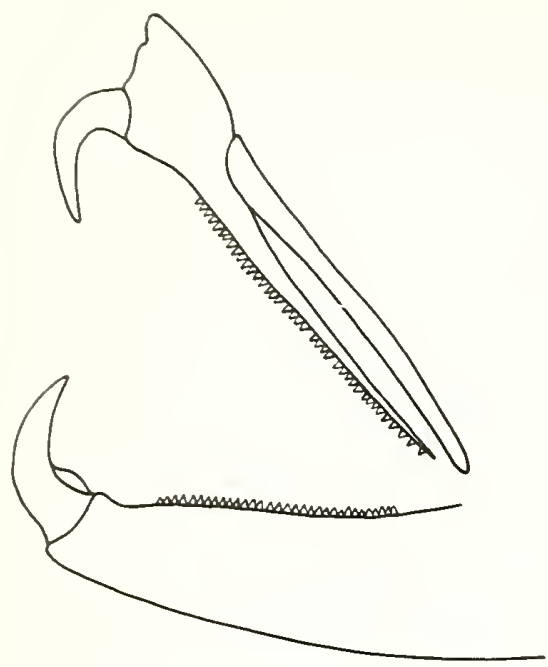

Figure K.- Ipper and lower jaw leeth in Onuxodon. Notice the gap between the large anterior teeth and the small posterior teeth.

3a. Rear of maxillary expanded; posterior margin a straight line. Body rather elliptical in cross section: width about 2 in depth . . . . . . . . . . . . . . . . . . . . . . . . Echiodon

3b. Rear of maxillary slender; posterior margin rounded. Body strongly compressed; width 3 or more

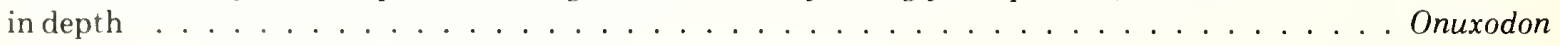

\section{Carapus Rafinesque}

(Fig. 9)

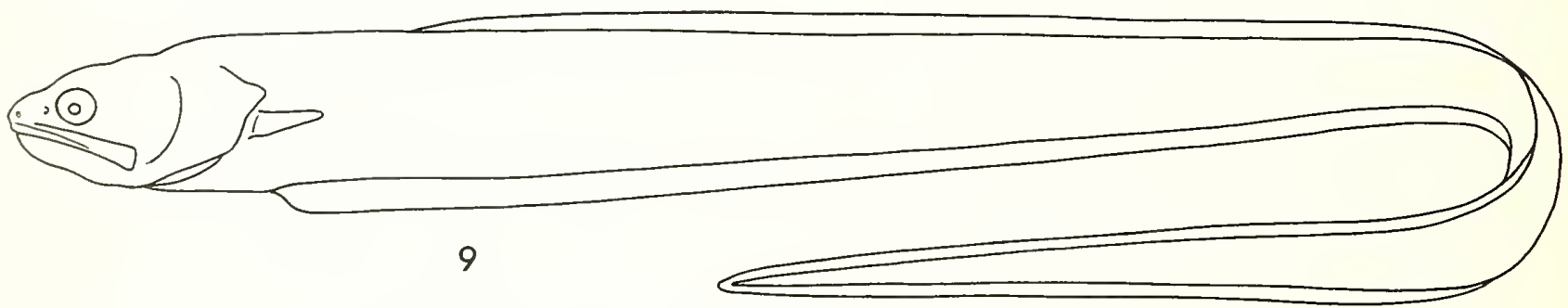

Carapus Rafinesque 1810 (type-species according to Opinion 42 of the International Commission on Zoological Nomenclature Gymnotus acus Linnaeus).

See Arnold (1956) for a discussion of the complex nomenclature of this genus and a list of synonyms.

Teeth in continuous bands on jaws and palatines. Enlarged teeth present in some but not as recurved canines at the jaw tips. Maxillary free. Vent close to a vertical from base of pectoral fin. No median rocker bone at anterior end of swim bladder.

Inquiline in holothurians, asteroids, bivalve mollusks, and tunicates; so far as known commensal (Trott 1970).

Circumtropical, also in Mediterranean.

The following list of 15 valid species is according to Arnold (1956) and Trott (1970): * ${ }^{*}$. acus (Brünnich 1768$)$, ${ }^{*} C$. bermudensis (Jones 1874), C. birpex Arnold 1956, C. boraborensis (Kaup 1856), *C. caninus (Günther 1862), C. cuspis Arnold 1956, C. dubius (Putnam 1874), ${ }^{*}$ C. homei (Richardson 1844), C. houlti (Ogilby 1922), C. kagoshimanus (Steindachner and Doderlein 1877), ${ }^{*}$ C. mourlani (Petit 1934), C. owasianus Matsubara 1953, *C. parvipinnis (Kaup 1856), C. pindae (Smith 1955), and ${ }^{*} C$. variegatus Fowler and Steinitz 1956. 


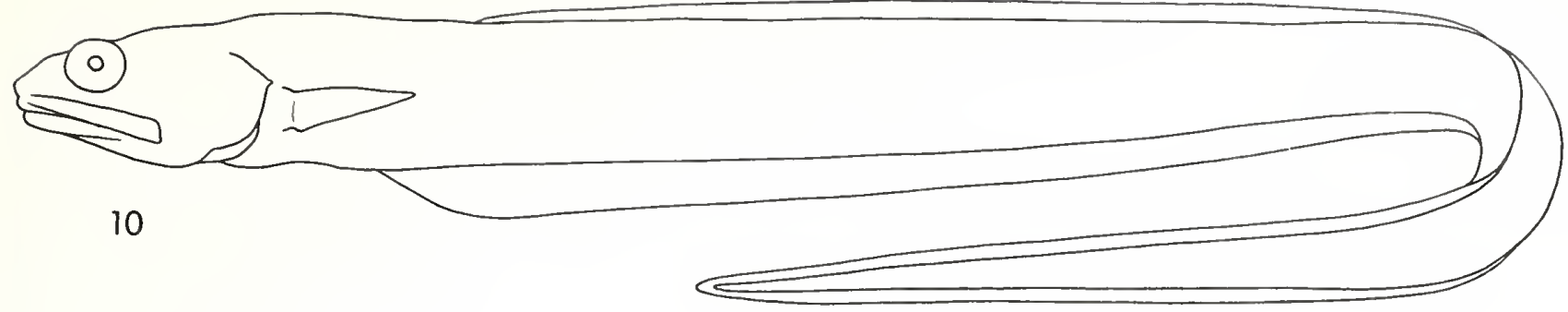

Echiodon Thompson (1837:55; type-species by monotypy Echiodon drummondii Thompson).

Teeth in bands on jaws and palatines. Upper and lower jaws with a pronounced gap between enlarged recurved canines at the jaw tips and the smaller teeth in bands. Maxillary free. Body rather elliptical in cross section. Vent well posterior to a vertical from base of pectoral fin. No median rocker bone at anterior end of swim bladder.

Probably free living (Trott 1970).

Tropical and temperate North Atlantic including the Mediterranean, tropical eastern Pacific, subantarctic seas, and possibly western Indian Ocean and southwestern Pacific.

The genus, which is being studied by M. Leiby, D. Markle, and J. Olney, contains at least three described species plus one or two undescribed and two problematic ones: $E$. dentatus (Cuvier 1817), ${ }^{*} E$. drummondii Thompson 1837 , and $E$. exsilium Rosenblatt 1961. See Arnold (1956) concerning the status of Carapus cinereus Smith 1955 and C. rendahli Whitley 1941.

Encheliophis Muller

(Fig. 11)

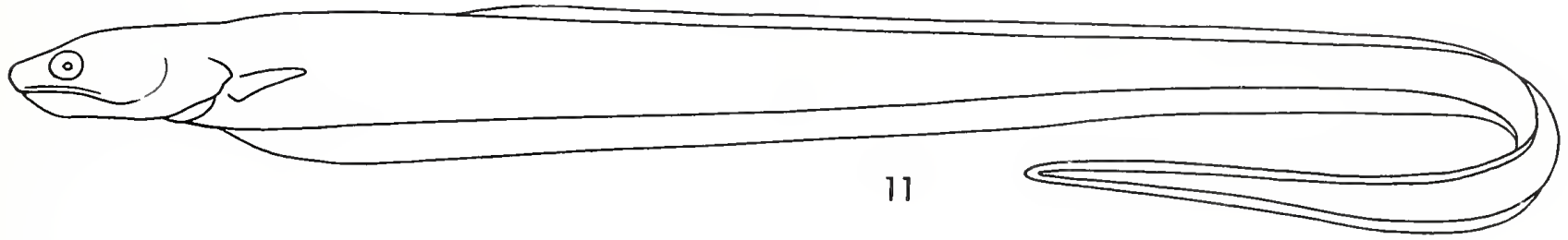

Encheliophis Müller (1842:205; type-species by monotypy Encheliophis vermicularis Müller).

Jordanicus Gilbert (1905:656; type-species by monotypy Fierasfer umbratilis Jordan and Evermann 1903).

Encheliophiops Reid (1940:47; type-species by original designation Encheliophiops hancocki Reid 1940).

Teeth in single rows on jaws and palatines. No canines. No large gap in the tooth row near the tip of the jaw. Maxillary bound by skin to side of head (Fig. 7a). Vent close to a vertical from base of pectoral fin, or pectoral fin absent. No rocker bone at anterior end of swim bladder.

Parasitic in shallow-water holothurians (Trott 1970; Trott and Trott 1972).

Tropical Pacific and Indian Oceans.

Four species in two subgenera (see Arnold 1956 and Trott 1970, 1972): E. (Encheliophis) jordani Heller and Snodgrass $1903,{ }^{*} E$. (E.) vermicularis Müller $1842,{ }^{*}$ E. (Jordanicus) gracilis (Bleeker 1856), and E. (J.) sagamianus (Tanaka 1908).

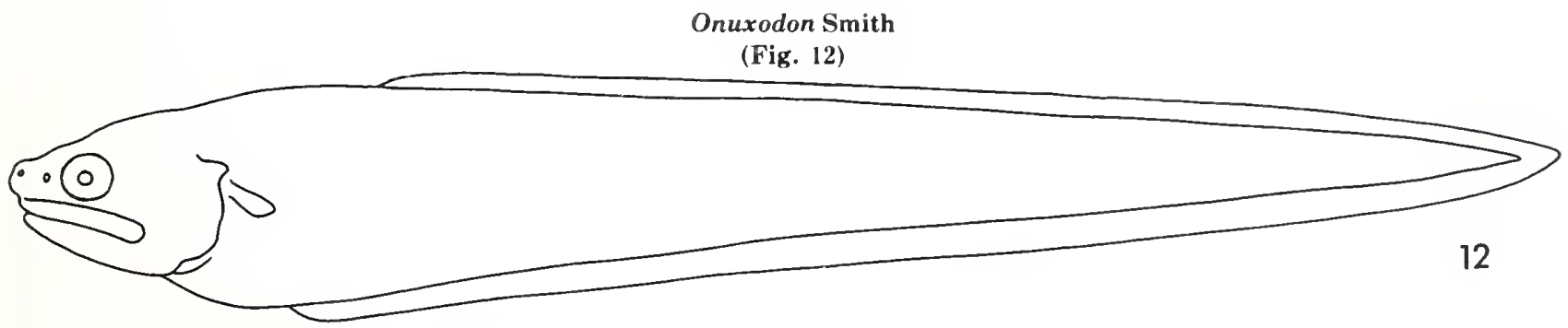


(Imuxdon Smith (1955b:405; type-species by original designation Carapus parvibrachium Fowler).

Teeth in bands on jaws and palatines. One or more pair of enlarged recurved canines at the tip of each jaw, separated by a pronounced gap from the smaller teeth in bands (Fig. 8). Maxillary free. Head and body deep, compressed. Median rocker bone present at anterior end of swim bladder. (Courtenay and McKittrick 1970; Tyler 1970).

Omuxodon was treated as a subgenus of Carapus by Arnold (1956); however, Courtenay and McKittrick (1970) and

Tyler (1970) have shown that it requires full generic status. It seems closer to Echiodon than to Carapus.

Inquiline in the mantle cavity of shallow-water bivalve mollusks, particularly Pycnodonta hyotis (Trott and Trott 1972 ).

Western Indian Ocean to the Philippines and Fiji.

At least two species: ${ }^{*} O$. margaritiferae (Rendahl 1921), ${ }^{*} O$. parvibrachium (Fowler 1927), ¿Carapus reedi Smith 1955 h isee Arnold 1956).

\section{Ophidiidae Rafinesque 1810}

Supramaxillary present. Dorsal fin rays usually equal to or longer than opposing anal fin rays. Scales present on body. So far as known no vexillifer larval stage.

\section{KEY TO SUBFAMILIES OF OPHIDIIDAE}

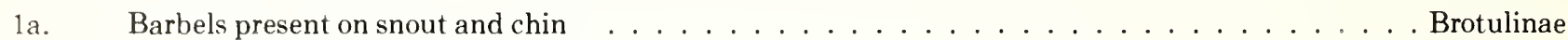

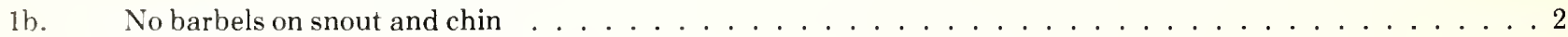

2a. Scales in the form of small, nonimbricate prickles (Fig. 13) $\ldots \ldots \ldots$. . . . Brotulotaeniiae

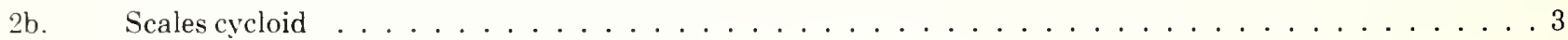
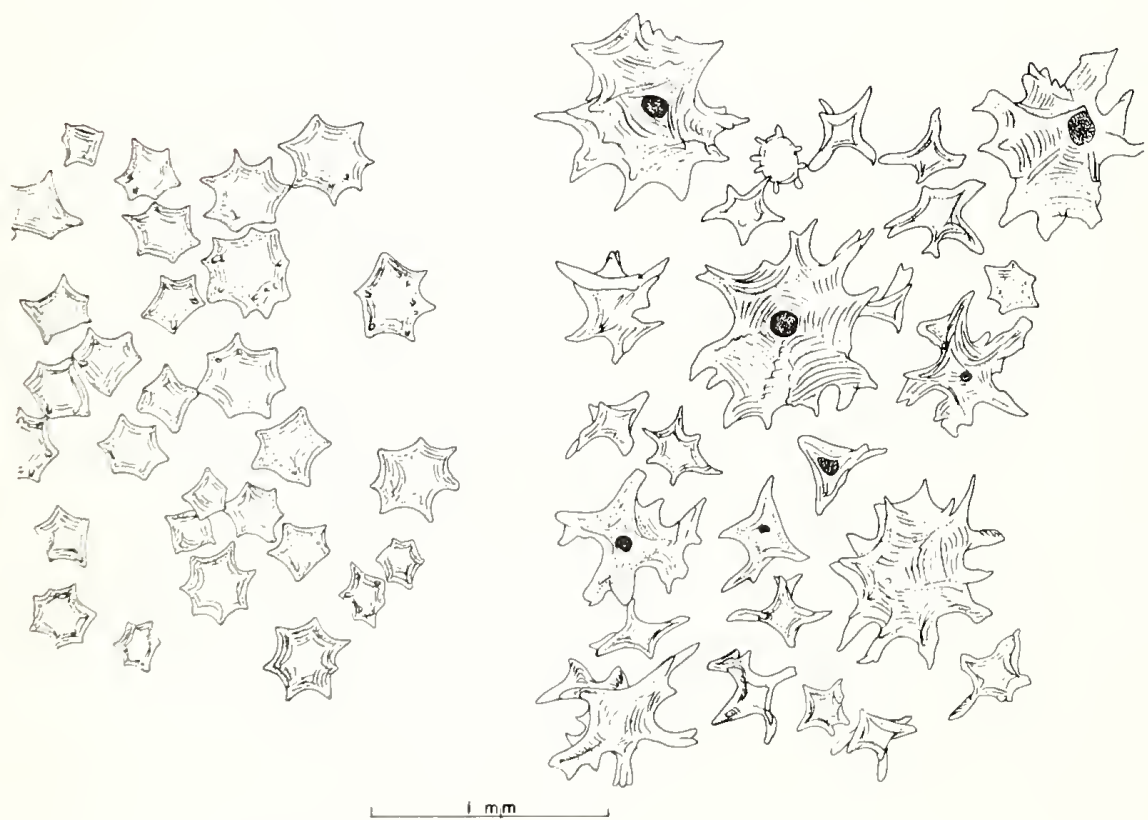

Figure 13.- Brotulotaenia body scales. Left, a juvenile; right, a very large specimen.

3a. Main body of the ventral arm of the cleithrum meeting its mate at about the level of the preopercle, whence a slender elongate tilament of bone extends anteriorly to the ventral fins (Fig. 14a) inserted beneath the eye. Median basibranchial tooth patch present or absent . . . . . . Ophidiinae

3h. Ventral arm of cleithrum meeting its mate and terminating at about level of preopercle or farther anteriorly, but no slender, elongate, anteriorly extending filament of bone (Fig. 14b). Ventral fin insertion variable in position, fin absent in a few species. One or more median basibranchial tooth patches (except absent in one Bassozetus and two Lamprogrammus species) . . Neobythitinae 

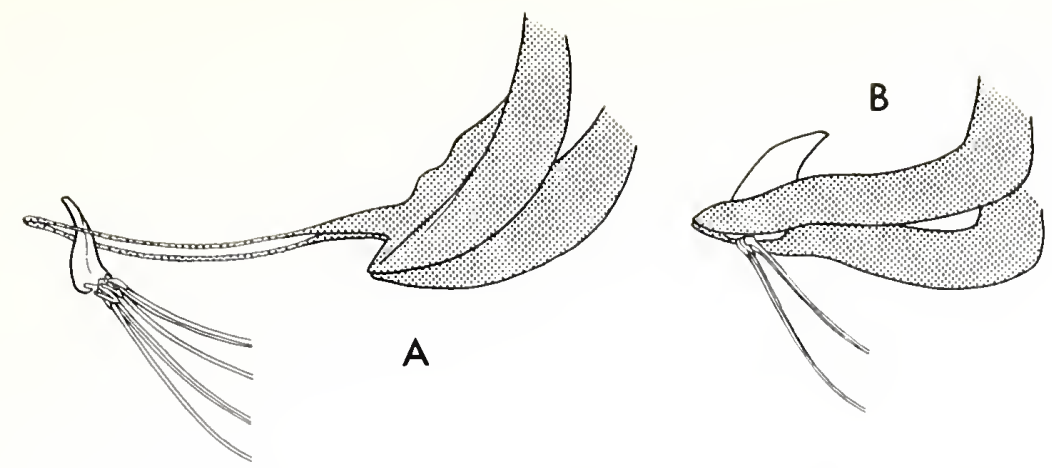

Figure 14.- Ventral fin support in two subfamilies of ophidiid fishes. A. Ophidiinae, note the slender filament of bone extending anteriorly from the main body of the cleithrum; B. Neobythitinae.

\section{BROTULINAE SWAINSON 1838}

Barbels present on snout and chin. Body completely covered with small, imbricate cycloid scales. Ventral fins with 2 rays in each, at about the level of the preopercle in position, well behind the eye. Median basibranchial tooth patch absent. Caudal fin rays 10 or 11 , supported by a parhypural, 2 free hypurals, and 2 epurals. Branchiostegal rays 8 . Developed gill rakers on first arch 4 or fewer.

A single genus.

\section{Brotula Cuvier}

(Fig. 15)

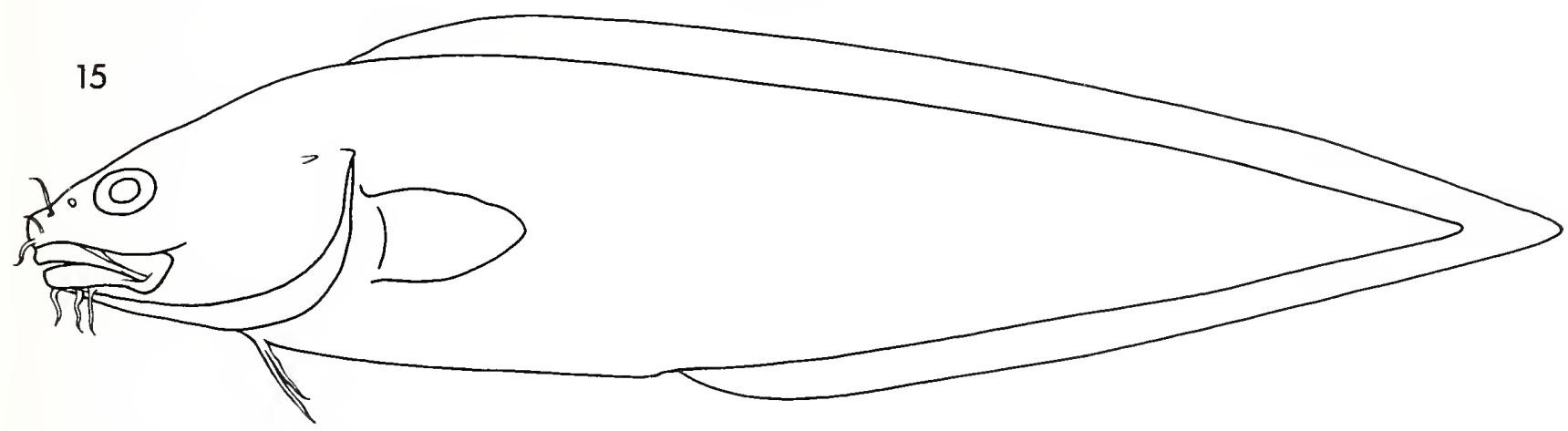

Brotula Cuvier (1829:335; type-species by monotypy Enchelyopus barbatus Bloch).

Nematobrotula Gill (1863a:252; type-species by original designation Brotula ensiformis Günther 1862).

Geneiates Tickell in Day (1888:804; type-species by monotypy Geneiates ferruginosus Tickell, places in synonymy of Brotula multibarbata by Day 1888).

Early stages pelagic and in reef areas, often spotted. Adults benthic offshore to depths of $650 \mathrm{~m}$ but most common shallower than $180 \mathrm{~m}$.

Worldwide in tropical seas.

At least five species; see Hubbs (1944) and Gosline (1953) for additional references: ${ }^{*} B$. barbata (Bloch) in Bloch and Schneider $1801,{ }^{*} B$. clarkae Hubbs $1944,{ }^{*} B$. multibarbata Temminck and Schlegel $1846, B$. ordwayi Hildebrand and Barton 1949, and B. townsendi Fowler 1900.

\section{BRoTULOTAENIINAE NEW SUBFAMILY}

No barbels on chin and snout. Scales in the form of small, nonimbricate prickles. Ventral fins absent. No anterior projection from the symphysis of the cleithrum, which is at about the level of the rear end of the maxillary, well posterior to the eye. Median basibranchial tooth patch absent. Gill rakers in the form of tooth-bearing tubercles. Caudal fin rays usually 9. Branchiostegal rays 7 (rarely 6). Otoliths minute, foreshortened, and compressed. See Cohen (1974a) for osteology. 
A separate subfamily is proposed for Brotulotaenia because it is divergent from all other ophidiid genera and not obriously related to any of them. Three characters which immediately distinguish Brotulotaenia from all other ophidiid genera are the nature of its scales (Fig. 13), the form of its gill rakers (Cohen 1974a, figure 5), and the size and shape of its otolith (Cohen 1974a, figure 2; W. Schwarzhans, pers. commun.). Brotulotaenia further differs from Neobythitinae (except for two species of Lamprogrammus and one of Bassozetus) and resembles Brotulinae in lacking a median basibranchial tooth patch. Characters of Brotulinae that are not shared with Brotulotaenia include the presence of barbels, a notably elongated cranium, and a well-developed caudal fin support consisting of epurals, hypurals, and a parhypural. Ophidiinae differs in the slender anterior projection from the cleithrum (Fig. 14a).

\section{Brotulotaenia Parr}

(Fig. 16)

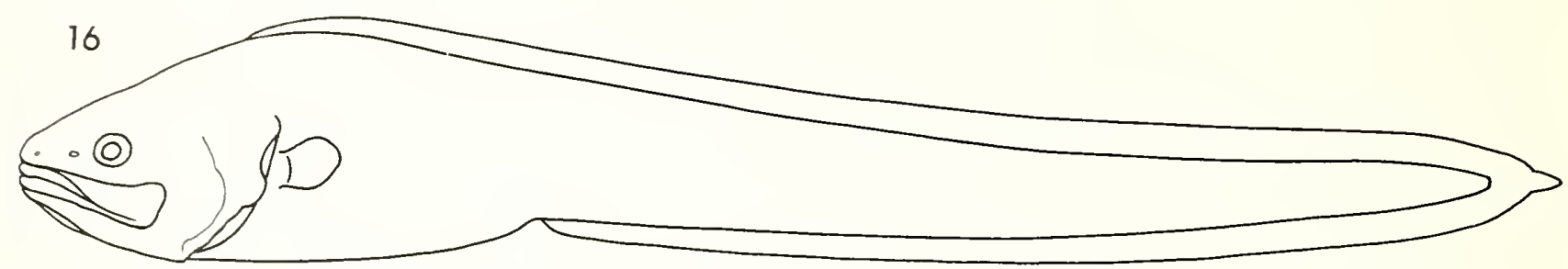

Brotulotaenia Parr (1933:48; type-species by original designation Brotulotaenia nigra Parr).

Meso- and bathypelagic in tropical seas.

The four nominal species have been reviewed by Cohen (1974a): ${ }^{*} B$. brevicauda Cohen 1974a, ${ }^{*} B$. crassa Parr 1934, ${ }^{*}$ B. nielseni Cohen $1974 \mathrm{a}$, and ${ }^{*} B$. nigra Parr 1933.

\section{OPHIDIINAE RAFINESQUE 1810}

No barbels on snout and chin. Body covered with small, cycloid scales. Main body of the ventral arm of the cleithrum meeting its mate at about the level of the preoperculum, whence a slender, elongate filament of bone (Fig. 14a) extends anteriorly to the ventral fin, which is at about the level of the orbital region in position. Ventral fins with 2 rays in each. Median basibranchial tooth patch present or absent. Caudal fin rays 9 . Developed gill rakers 10 or fewer. Branchiostegal rays 7 .

In general, benthic fishes of the continental shelf.

\section{Key to Tribes of Ophidiinae}

1a. All body scales in regular rows, rounded . Lepophidiini

1b. All or most body scales at oblique angles to each other, elongate or elliptical (Fig. 17) . . . . . . .Ophidiini

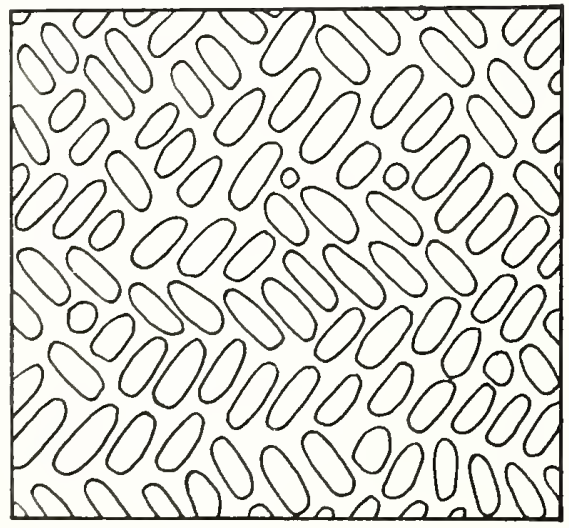

Figure 17.-Ophidiini body scales. 


\section{Lepophidiini Robins 1961}

All body scales in regular rows, rounded. Three genera presently recognized (Robins 1962).

Key to Genera of Lepophidiini

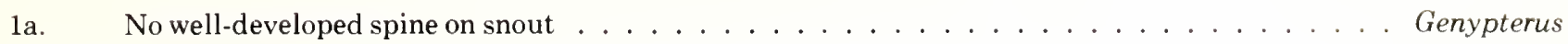

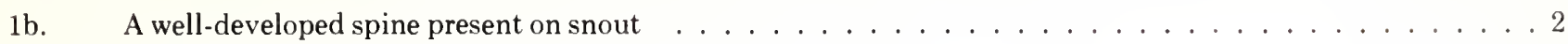

2a. A narrow row of weak median basibranchial teeth. Peritoneum dark . . . . . . . . Cherublemma

2b. No median basibranchial teeth. Peritoneum pale .............. Lepophidium

\section{Cherublemma Trotter}

(Fig. 18)

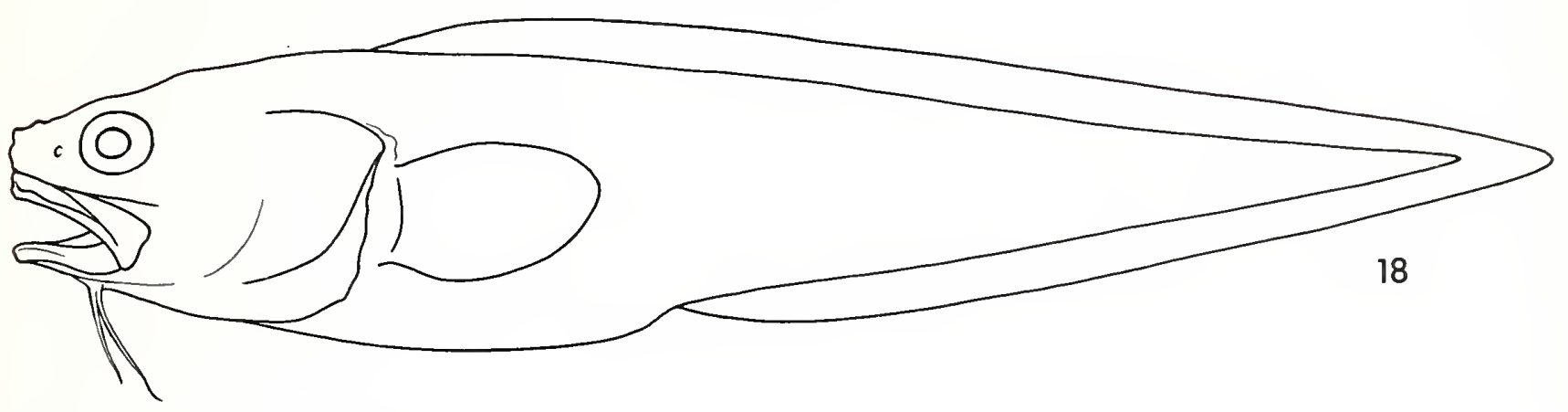

Cherublemma Trotter (1926:119; type-species by monotypy Cherublemma lelepris Trotter).

Brotuloides Robins (1961:214; type-species by original designation Leptophidium emmelas Gilbert).

Well-developed spine on snout. Narrow row of weak median basibranchial teeth present. Peritoneum dark. Bones poorly ossified.

Cherublemma does not seem very similar to either of the other two genera in this tribe. Its immediate relationships may become more apparent when it is better known.

Tropical eastern Pacific.

Upper continental slope; early stages have been caught in midwater trawls.

A single species: ${ }^{*}$ C. emmelas (Gilbert 1890$)\left({ }^{*}\right.$ Cherublemma lelepris Trotter 1926 is a synonym).

\section{Genypterus Philippi}

(Fig. 19)

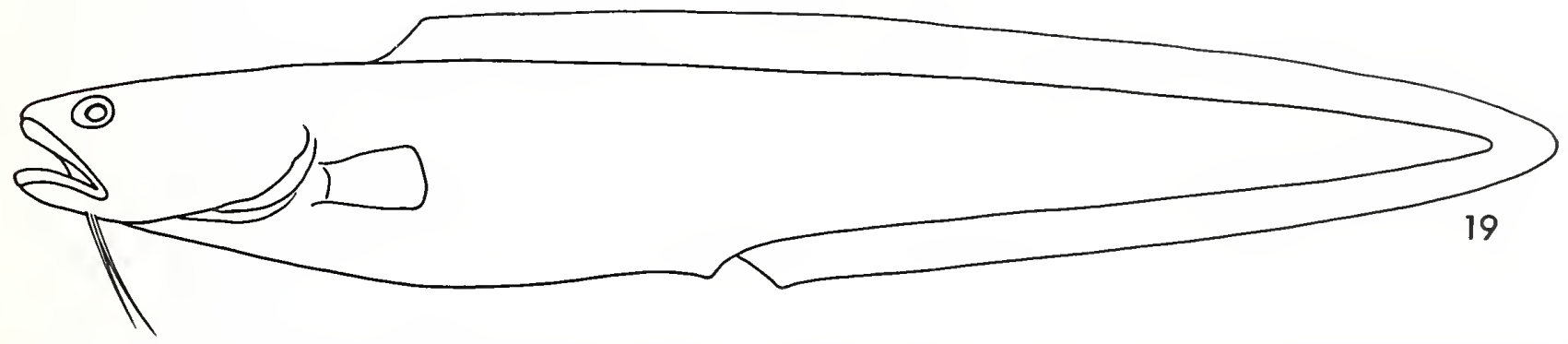

Xiphiurus Smith (1847 in 1838-47:110; type-species by monotypy Xiphirurs capensis Smith). Robins and Lea (1976) have appealed to the International Commission on Zoological Nomenclature to suppress this little used name.

Genypterus Philippi (1857:268; type-species by monotypy Genypterus nigricans Philippi 1857).

Hoplophycis Kaup (1858:92; type-species by monotypy Hoplophycis lalandi Kaup 1858).

No well-developed spine on snout. Basibranchial tooth patches present or absent. Peritoneum pale. The osteology of three Chilean species has been described by Toro and Dazarola (1969). 
Abundant fishes of the continental shelf and slope in temperate waters of the Southern Hemisphere. Several species are fished commercially.

The nomenclature is tangled, and the literature is apparently filled with misidentifications. A much-needed revision of these important fishes is being carried on by C.R. Robins. At least five species: ${ }^{*} G$. blacodes (Schneider in Bloch and Schneider 1801), G. capensis (Smith 1847 in 1838-47), G. chilensis (Guichenot 1848), G. maculatus (Tschudi 1846 in 1844-46), and G. microstomus Regan 1903.

\section{Lepophidium Gill}

(Fig. 20)

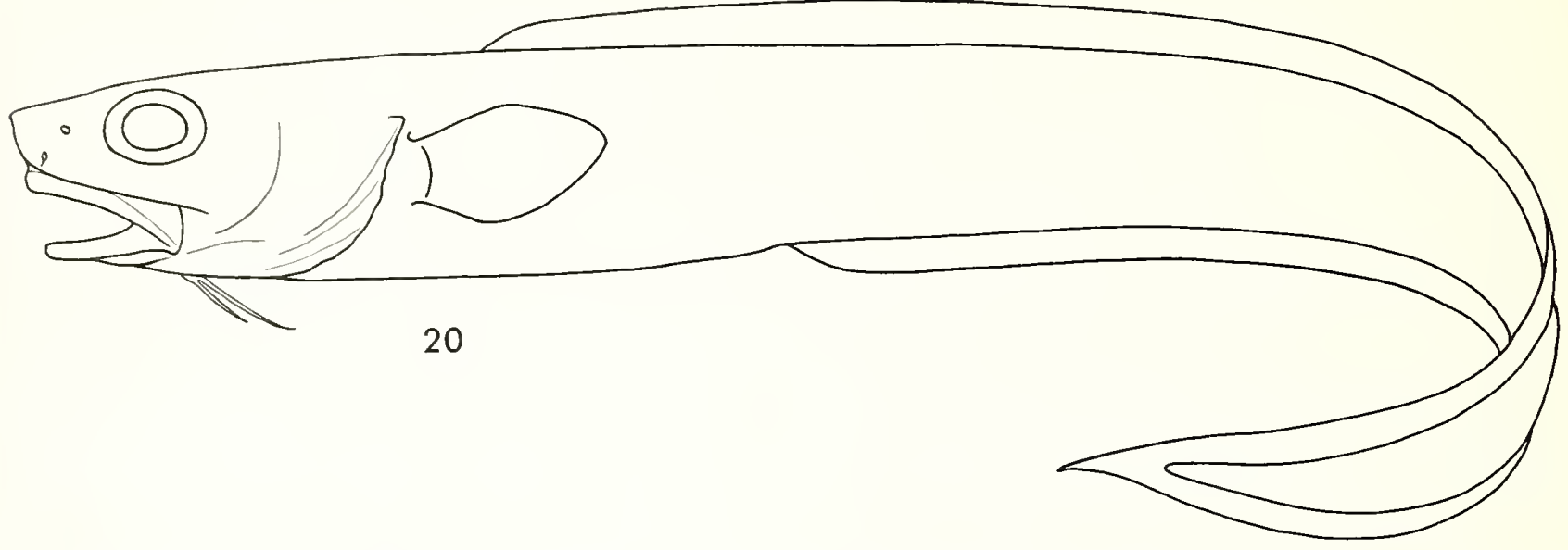

Leptophidium Gill (1863b:210; type-species by monotypy Leptophidium profundorum Gill). Preoccupied by Leptophidium Hallowell 1860 in snakes.

Lepophidium Gill (1895:167; replacement name for Leptophidium Gill 1863b, taking the same type species).

Well-developed spine on snout. No median basibranchial tooth patch. Peritoneum pale.

Tropical American continental shelf, although taken as far north as Georges Bank off New England in the western Atlantic and off southern California in the eastern Pacific. A single specimen of $L$. cervinum has been reported from the Mediterranean (Nielsen and Bini 1972).

There are 15 valid described species and at least five undescribed ones (see Robins 1958, 1962). Additional studies are in progress by Robins and name changes will be made. The species are: L. aporrhox Robins 1961, ${ }^{*} L$. brevibarbe (Cuvier 1829), ${ }^{*}$ L. cervinum (Goode and Bean 1885), L. graellsi (Poey 1861), L. jeannae Fowler 1941, ${ }^{*} L$. kallion Robbins 1959. L. marmoratum (Goode and Bean 1885), L. microlepis (Gilbert 1890), ${ }^{*}$ L. negropinna Hildebrand and Burton 1949. L. pardale (Gilbert 1890), ${ }^{*}$ L. pheromystax Robins $1960,{ }^{*}$ L. profundorum (Gill 1863b), L. prorates (Jordan and Bollman 1890), *L. staurophor Robins 1958, and L. stigmatistium (Gilbert 1890).

\section{Ophidiini Rafinesque 1810}

At least some body scales at oblique angles to each other and elliptical to elongate in shape.

The species of cusk eels with a basket-weave pattern of squamation are not at this time easily separated into genera. Norman (1966) placed them in two genera; we follow C. R. Robins and R. Lea (pers. commun.) in allocating the species among five. As the species become better known and numerous unnamed ones are described, a classification will emerge that is likely to differ considerably from the one presented below.

Many species are known to show a high degree of sexual dimorphism in the form of the swim bladder (Harry 1951). Additionally, some species have a prominent rocker bone at the anterior end of the swim bladder, which is controlled by a complex of muscles and ligaments (Svetovidov 1961; Rose 1961; Courtenay 1971). Although the swim bladder and associated structures have been used as taxonomic characters, there is not yet any clear phyletic pattern discernible in the distribution of various character states.

\section{Key to Genera of Ophidiini}

1a. Scales absent on head (except in one species of Ophidion which has a small patch in front of the eye) .... 3

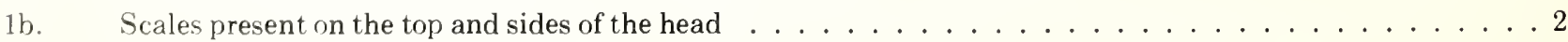


2a. Rays of each pelvic fin equal in length or nearly so. Spine on snout weak or absent

2b. Rays of each pelvic fin unequal in length. Spine on upper part of snout short and strong, emer-

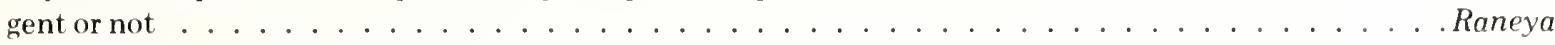

3a. Dorsal fin rays about 200. Anal fin rays 150 or more. Precaudal vertebrae 19 . . . . . . . . . . Chilara

3b. Dorsal fin rays rarely if ever more than 150 . Anal fin rays rarely more than 125 . Precaudal verte-

brae 18 or fewer

4a. Snout spine absent, or if present slender and anteriorly directed at its tip. Precaudal vertebrae $15-18$

Ophidion

4b. Snout spine present, stout, with a blunt, anterodorsally directed tip. Precaudal vertebrae 13-

\section{Chilara Jordan and Evermann}

(Fig. 21)

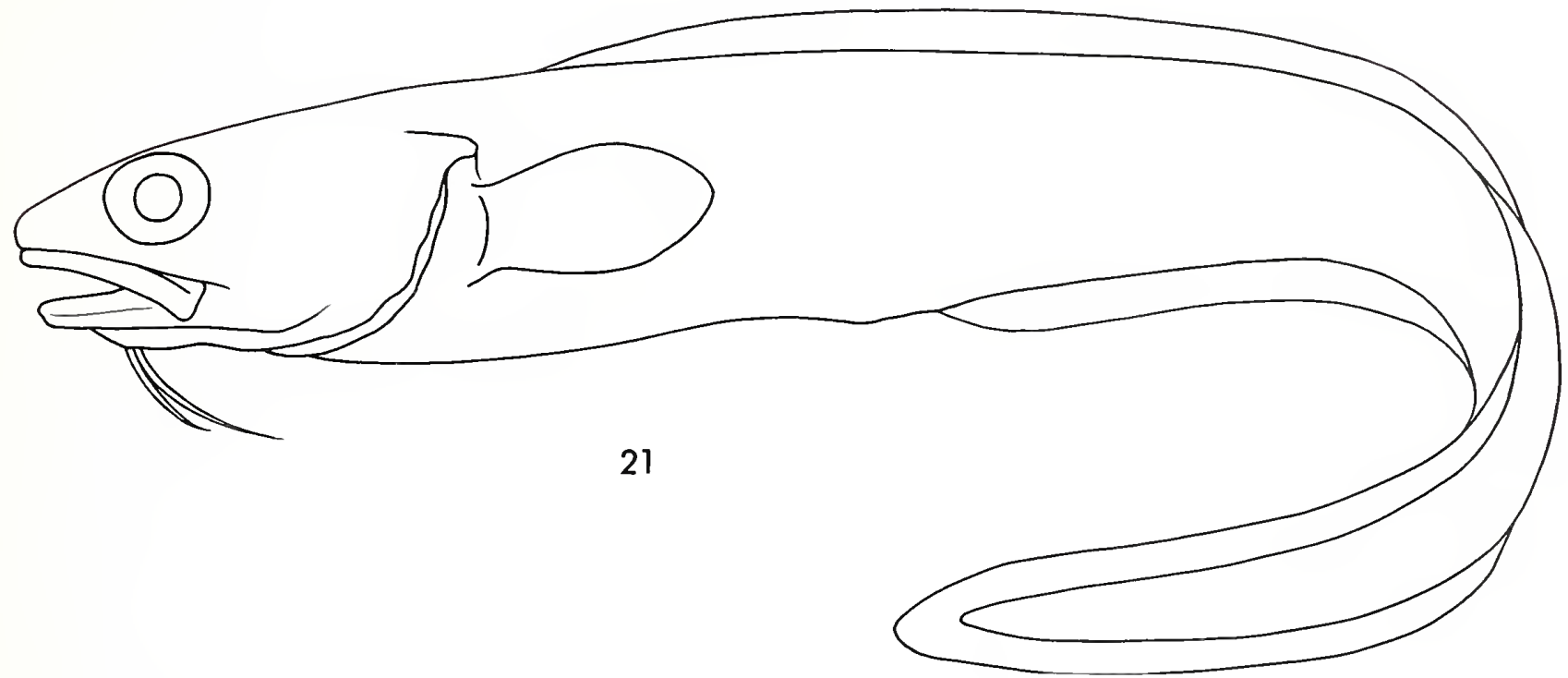

Chilara Jordan and Evermann (1896:482; type-species by monotypy Ophidium taylori Girard).

Scales absent from head. Rays of each pelvic fin unequal in length. Spine on snout absent. This genus, which is close to Ophidion, is apparently characterized by its high fin ray and vertebral counts. Dorsal fin rays about 200 ; anal fin rays about 150 or more; developed gill rakers on first arch 5 to 9; precaudal vertebrae 19.

Continental shelf of the temperate eastern North Pacific from Oregon to Baja California.

A single species, ${ }^{*}$ C. taylori (Girard 1858).

Ophidion Linnaeus

(Fig. 22)

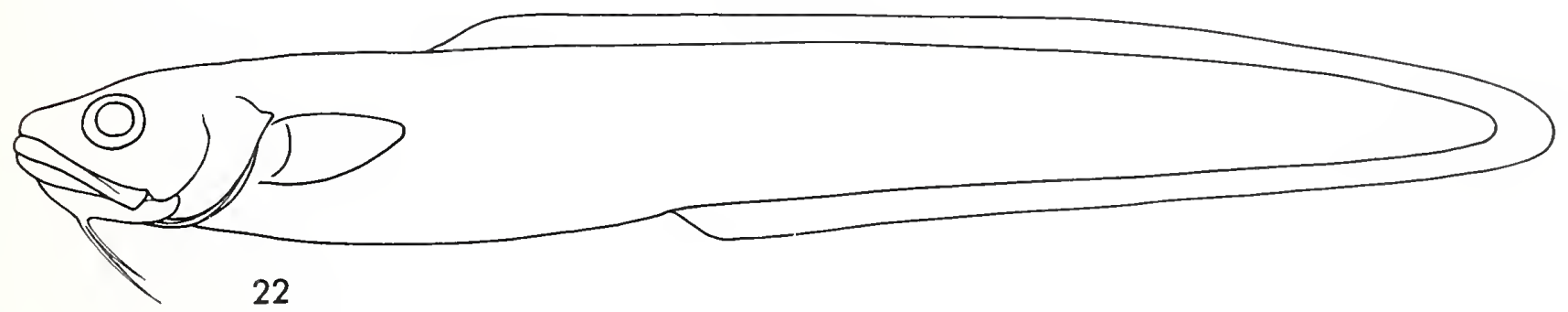


Ophidion Linnaeus (1758:259: trpe-species by subsequent designation of Jordan and Evermann 1896, Ophidion barbatum linnaeus).

Riwola Jordan and Evermann (1896:483; type-species by monotypy Ophidium marginatum DeKay).

scales absent from top of head and from sides as well, except in a single, presently unnamed species, which has a small patch in front of the eve (C. R. Robins, pers. commun.). Rays of each ventral fin unequal in length. Developed rakers on first gill arch 4 to 7 . Precaudal vertebrae 15 to 18 . Snout spine absent or, if present, slender and directed anteriorly at its tip.

Tropical and warm temperate waters around the world. Continental shelf, including reefs.

The taxonomy of Ophidion requires clarification. R. Lea and C. R. Robins, who are studying the genus, mentioned ${ }^{*} 10$ species in the western Atlantic alone. Tentatively assigned to Ophidion are the following 18 described species: $O$. asiro (.Jordan and Fowler 1902), O. barbatum Linnaeus $1758,{ }^{*}$ O. beani Jordan and Gilbert $1883,{ }^{*} O$. fulvum (Hildebrand and Barton 1949). *O. galeoides (Gilbert 1890), O. genyopus Ogilby $1897,{ }^{*}$ O. grayi (Fowler 1948), *O. holbrooki (Putnam 1.8 - 1). O. iris Breder 1936 (O. nigricauda Breder 1936 is a synonym), * O. lagochila (Böhlke and Robins 1959), *O. marginatum (DeKay 1842, ${ }^{*} O$. muraenolepis (Günther 1880), *O. nocomis Robins and Böhlke $1959,{ }^{*} O$. rochei Müller 1845 , O. scrippsae (Hubbs 1916), ${ }^{*}$ O. selenops Robins and Böhlke 1959, ${ }^{*}$ O. smithi (Fowler 1934), and ${ }^{*} O$. welshi (Nichols and Breder 1922).

Otophidium Gill

(Fig. 23)

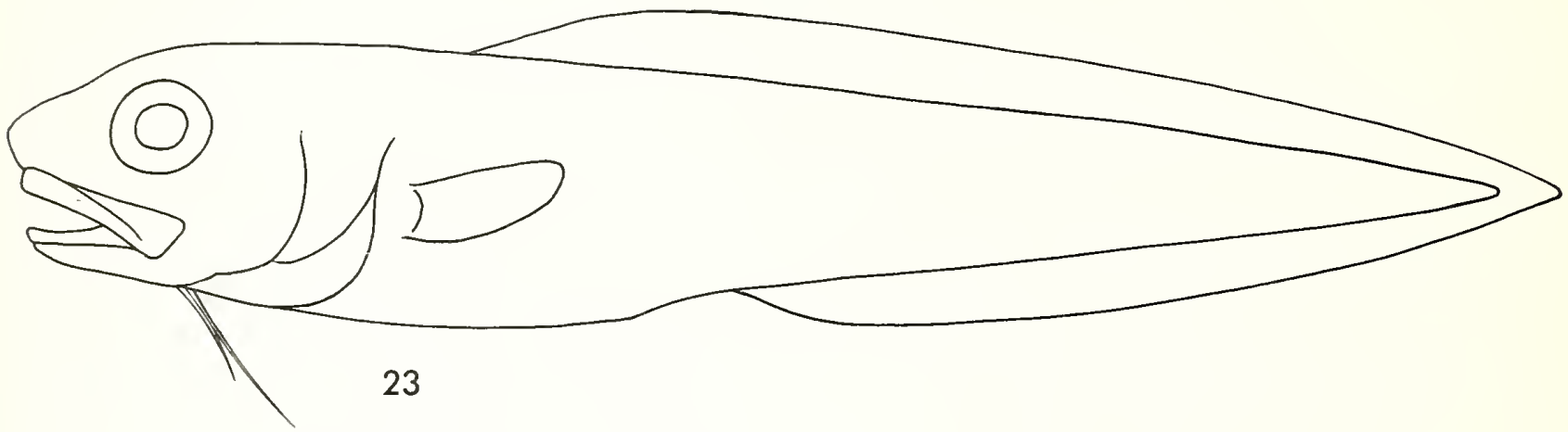

Otophidium Gill in Jordan (1887:126; type-species by original designation Genypterus omostigma Jordan and Gilbert).

Scales absent from head. Rays of each ventral fin unequal in length. Developed rakers on each gill arch 4 to 7 . Precaudal vertebrae 13 to 15 . Snout spine blunt, anterodorsally directed at its tip.

Warm temperate and tropical waters of the Americas. Found on the continental shelf, including reefs.

Four described species are tentatively assigned to this genus, which is being studied by C. R. Robins: ${ }^{*} O$. chickcharn९y' Böhlke and Robins 1959, O. dormitator Böhlke and Robins $1959,{ }^{*} O$. indefatigabile Jordan and Bollman 1890, and $*$ O. omostigmum (Jordan and Gilbert 1882).

Parophidion Tortonese

(Fig. 24)

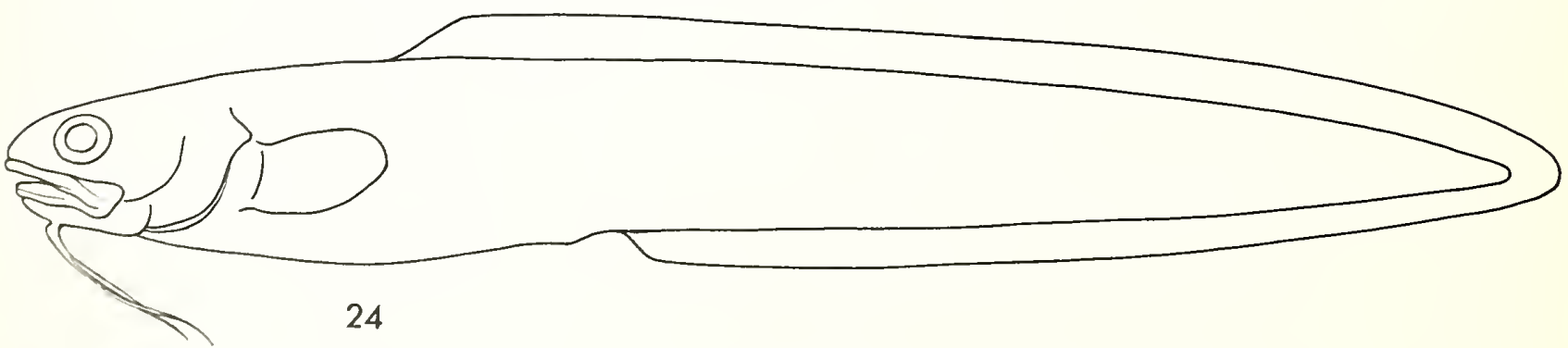

Iea. R. . . and $r$. R. Robins. 1975. Systematics of cusk eels (Family Ophidiidae) of the genus ()phidion from the western North Atlantic. American Society of Ichthyologists and Herpetologists, Abstracts, Fifty-fifth Annu. Meet., p. 100. 
Parophidion Tortonese (1954:5; type-species by original designation Ophidion vassali Risso).

Scales present on top and sides of head. Rays of each ventral fin equal in length or nearly so. Spine on snout weak or absent. Precaudal vertebrae 15 or 16 . Developed rakers on first arch 4.

Tropical western North Atlantic and Mediterranean in shallow water.

At least two species: P. schmidti (Woods and Kanazawa 1951), and *P. vassali (Risso 1810).

\section{Raneya Robins}

(Fig. 25)

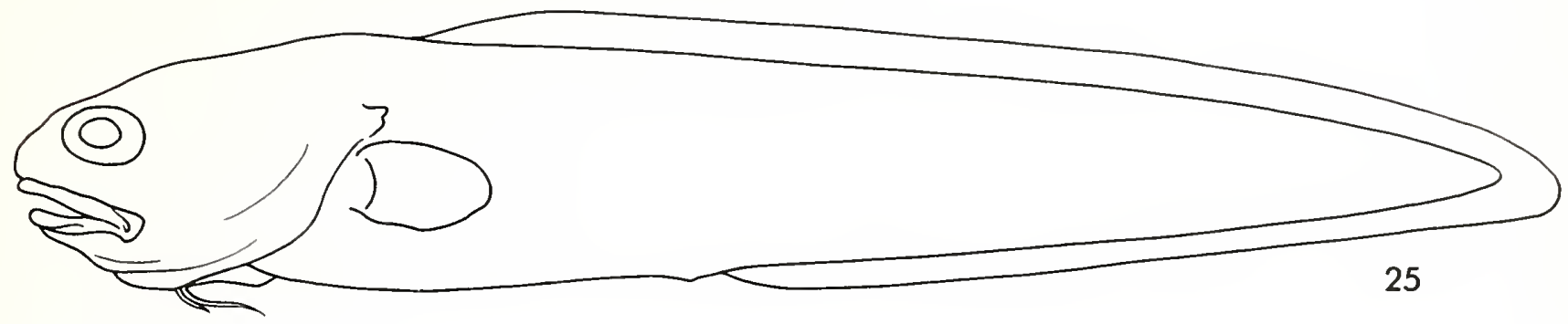

Raneva Robins (1961:212; type-species by original designation Lepophidium fluminense Ribeiro).

Scales present on top and sides of head. Rays of each ventral fin unequal in length. Spine on upper part of snout short and strong, sometimes buried. Precaudal vertebrae 15. Developed gill rakers on first arch 4.

Continental shelf of Brazil and Argentina (Menni and Lopez 1974).

A single species, *Raneya fluminensis (Ribeiro 1903).

\section{NEOBYTHITINAE RADCLIFFE 1913}

No barbels on snout and chin. Body covered with small cycloid scales. Ventral arm of cleithrum meeting its mate and terminating at about level of preopercle or farther forward, but no slender elongate anteriorly extending filament of bone. Ventral fin present in most genera, at about the level of the preopercle or farther forward, with 1 or 2 rays in each fin. Median basibranchial tooth patches 1 or more (except absent in some species of Lamprogrammus and Bassozetus); paired basibranchial tooth patches 0 or 1 . Caudal fin rays 6 to 12. Developed gill rakers 0 to 27. Branchiostegal rays 7 to 9.

A large and diverse group found around the world from the littorai to the greatest depth at which a fish has been caught. Mostly benthopelagic in habit.

Two tribes.

\section{Key to Tribes of Neobythitinae}

1a. Ventral fins at about the level of the orbital region in position, or if more posterior, then the fins are widely separated on the isthmus (Fig. 26B) . . . . . . . . . . . . Sirembini

1b. Ventral fins at about the level of the preopercle in position and close together (Fig. 26A), or

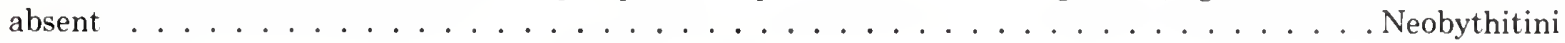

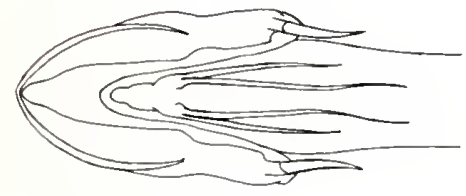

A

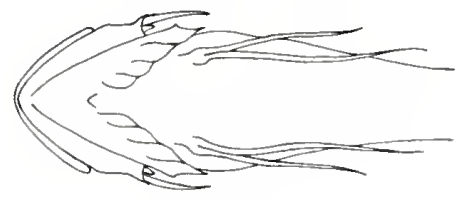

B
Figure 26.-Ventral fin insertions in two genera of Sirembini. A. Xyelacyba, close together; B. Tauredophidium, widely separate.

\section{Sirembini Gill 1863a}

Symphysis of the cleithra and the pelvic girdle at about the level of the orbital region (except in Tauredophidium, which has them at about the level of the preopercle but which may be distinguished from all other ophidiiform fishes by its widely separated ventral fins; see below). 
Sirembini as here constituted is most likely a heterogeneous assemblage, which probably will be reclassified. Within the tribe. Hoplobrotula and Dannevigia resemble each other; Xyelacyba, Tauredophidium, and possibly Acanthonus constitute another cluster; Sirembo is not very similar to any of the others.

\section{Key to Genera of Sirembini}

1a. Each rentral fin with a single ray. No spines on preopercle $\ldots \ldots \ldots \ldots$. . . . . . . . . . . . . . .

1b. Each ventral fin with 2 rays. Spines variously developed on preopercle $\ldots \ldots \ldots \ldots$

2a. Spine on opercle long, extending well beyond rear margin of head. Deepest part of fish usually

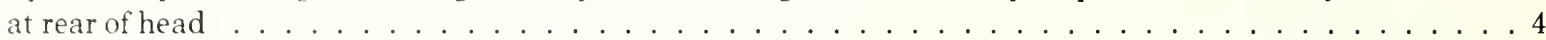

2h. Spine on opercle short, extending barely if at all beyond rear margin of head. Deepest part of fish usually posterior to rear part of head $\ldots \ldots \ldots \ldots \ldots \ldots$

3a. Several weak, skin-covered, or barely emergent spines at angle of preopercle. Pelvic fins inserted

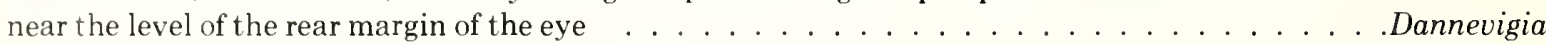

3b. Three strong emergent spines at angle of preopercle. Pelvic fins inserted beneath eye . . . . . Hoplobrotula

4a. Prominent, protruding, bifid spine on snout Acanthonus

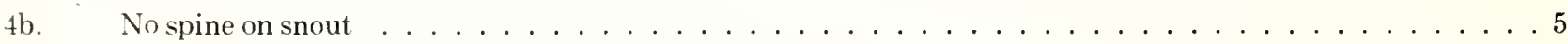

5a. Pelvic fins close to each other (Fig. 26a). Small but well-developed eyes at surface of head _ . . Xyelacyba 5h. Pelvic fins widely separated from each other (Fig. 26b). Eyes not visible at the surface of the

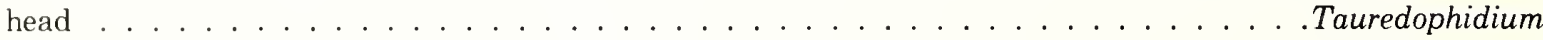

\section{Acanthonus Günther}

(Fig. 27)

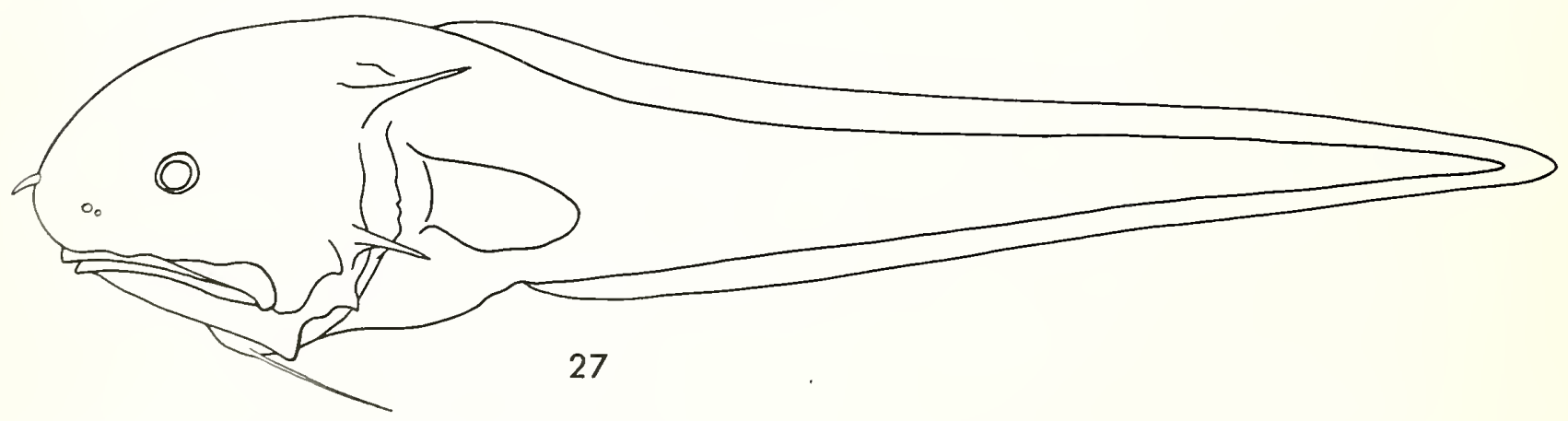

Acanthonus Günther (1878:22; type-species by monotypy A canthonus armatus Günther).

Prominent protruding bifid spine on snout. Ventral fins close together, each with 2 rays, inserted slightly posterior to the orbit. Spine on opercle long and slender, extending well beyond the rear margin of the head. Well-developed spines at lower angle of preopercle. Eyes at surface of head, small. Deepest part of fish at rear of head. Developed gill rakers on first arch 16 to 22. Median basibranchial tooth patches 1 to 4 . No dark spots on dorsal fin. A revision of the genus was presented by Nielsen (1965).

Circumtropical at abyssal depths.

A single species, *A. armatus Günther $1878\left({ }^{*}\right.$ A. spinifer Garman 1899 is a synonym). 


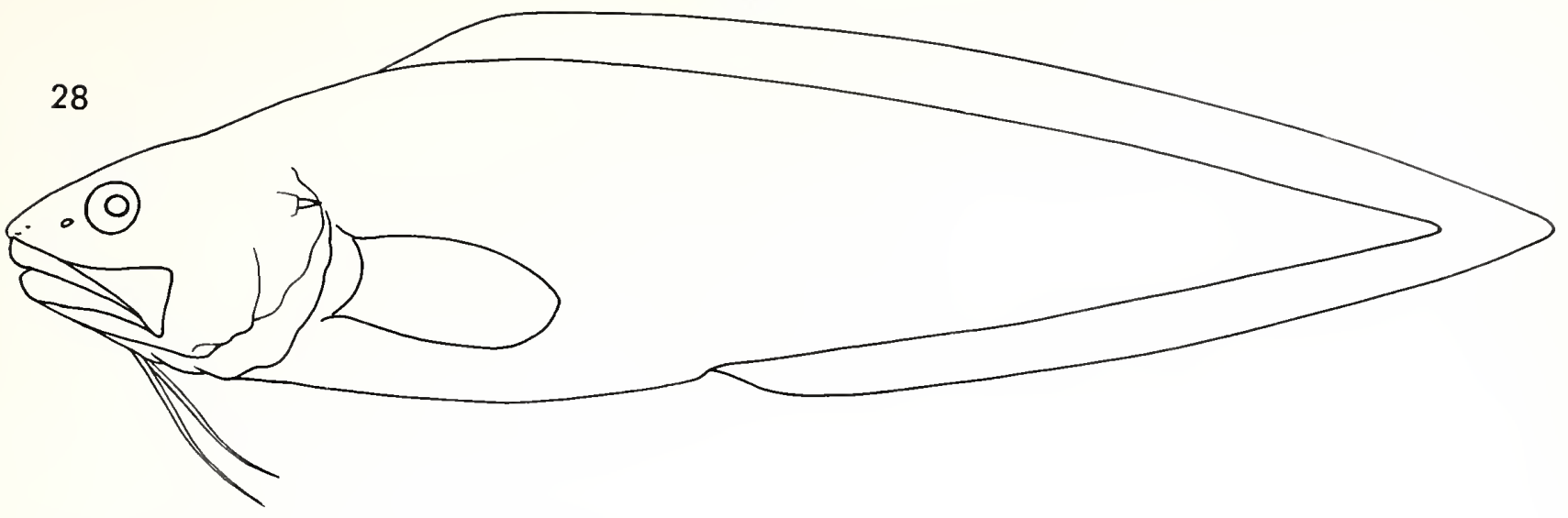

Dannevigia Whitley (1941:42; type-species by original designation Dannevigia tusca Whitley).

Ventral fins with 2 rays in each, fins closely adjacent, inserted close to the level of the rear margin of the eye. Several short weak concealed spines at angle of preopercle. Spine on opercle barely, if at all, reaching beyond rear margin of head. Fves well-developed. Deepest part of fish well posterior to head. Developed gill rakers on first arch 4. Median basibranchial tooth patches 2. No dark spots on dorsal fins.

Apparently restricted to the Great Australian Bight.

A single species, ${ }^{*} D$. tusca Whitley 1941.

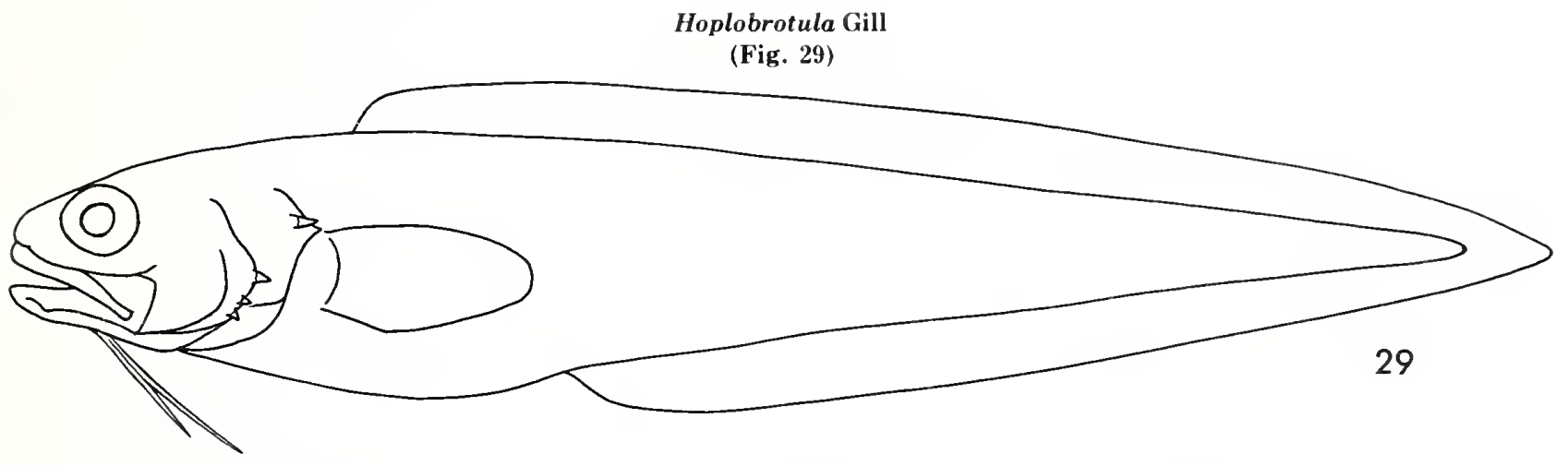

Hoplobrotula Gill (1863a:253; tvpe-species by original designation Brotula armata Temminck and Schlegel).

Ventral fins with 2 ravs in each, fins closely adjacent, inserted beneath the eye. Three strong emergent spines at angle of preopercle. Spine on opercle reaching barely if at all beyond rear margin of head. Eyes well-developed. Deepest part of fish generally posterior to head. Developed gill rakers on first arch 4 or 5 . Basibranchial with 1 median and 1 pair of tooth patches.

Deeper part of continental shelf. Japan and Indian Ocean.

Two nominal species: ${ }^{*} H$. armata (Temminck and Schlegel 1846), and ${ }^{*} H$. gnathopus Regan 1921.

\section{Sirembo Bleeker}

(Fig. 30)

Sirembo Bleeker (1858:22; type-species by subsequent designation of Vaillant 1888, "Sirembo imberbis Schleg." = Brotula imberbis Temminck and Schlegel).

Brotella Kaup (1858:92; type-species by subsequent designation of Jordan 1919, Brotula imberbis Temminck and Schlegel).

ITmalius Herre and Herald (1951:310; type-species by original designation Umalius philippinus Herre and Herald).

Ventral fins immediately adjacent to each other, each with a single ray, inserted beneath or immediately behind the eve. No spines on preopercle. Spine on opercle short, not reaching rear margin of opercle. Eyes well-developed. Deepest part of fish well posterior to head. Developed gill rakers on first arch 4. A single median basibranchial tooth patch. Several prominent dark spots on dorsal fin. 


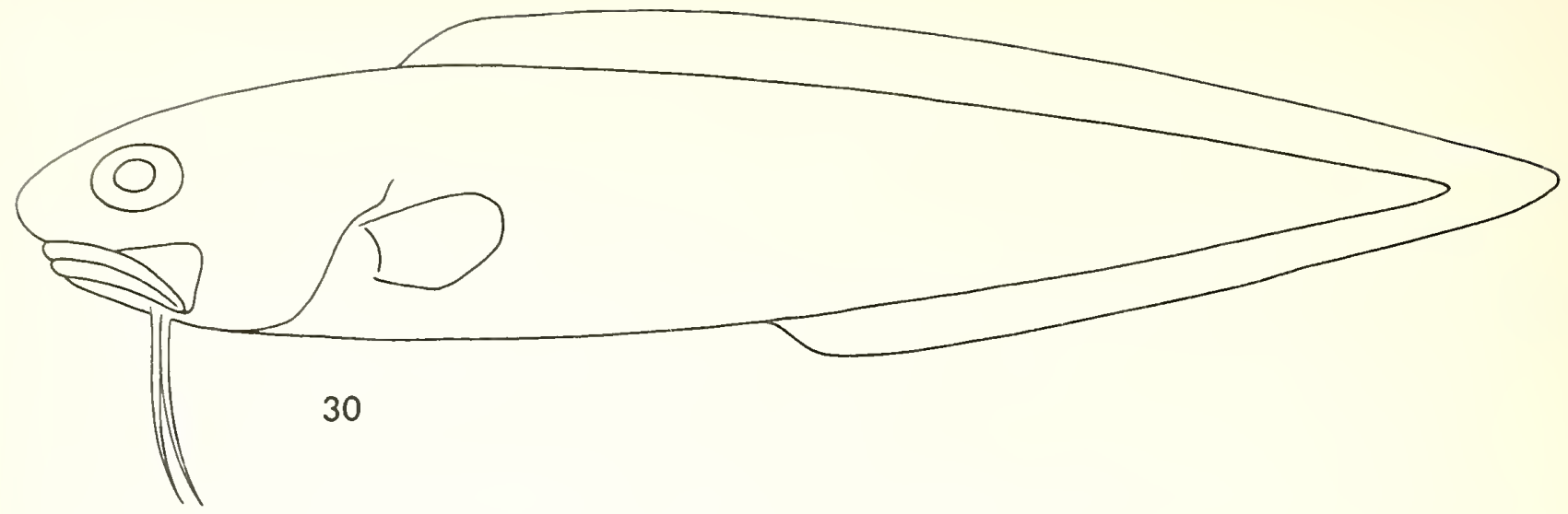

Continental shelf from the Red Sea to Japan, the Philippines, and Australia.

The genus has never been revised, Indian Ocean specimens are discussed by Menon and Rama Rao (1970) and Rao (1972). There are four nominal species: S. everriculi Whitley $1936,{ }^{*} S$. imberbis (Temminck and Schlegel 1846), $S$. jerdoni (Day 1888), *S. philippinus (Herre and Herald 1951).

\section{Tauredophidium Alcock}

(Fig. 31)

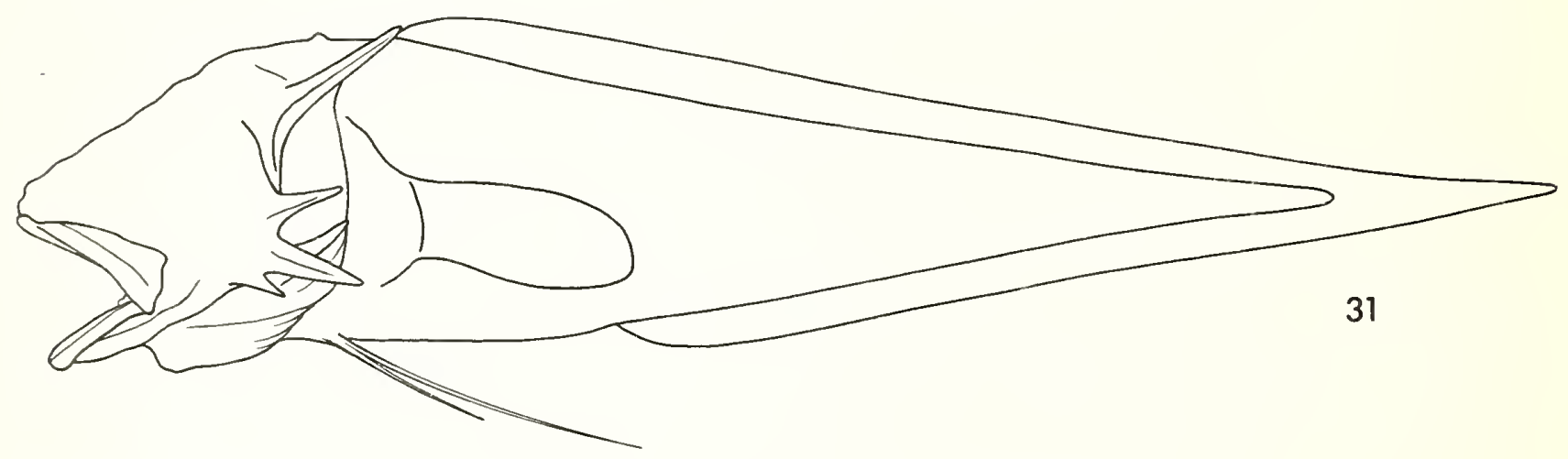

Tauredophidium Alcock (1890a:212; type-species by monotypy Tauredophidium hextii Alcock).

No spine on snout. Ventral fins inserted at about the level of the preopercle and widely separated from each other, on opposite sides of the isthmus (Fig. 26b). Spines on opercle and preopercle long, extending well beyond the rear margin of the head. Basibranchial with 1 median and 1 pair of tooth patches. Eyes not visible at the surface of the head. Deepest part of fish near rear of head. Developed gill rakers on first arch 8 or 9 . No dark spots on dorsal fin.

Tauredophidium is unique among ophidiiform fishes in the wide separation of its ventral fins. Except for this separation. the more posterior placernent of the ventral, and the regression of the eyes, the genus is very similar to Xyelacyba.

Abyssal depths in the Indian Ocean.

A single species, ${ }^{*} T$. hextii Alcock 1890a.

\section{Xyelacyba Cohen}

(Fig. 32)

Xvelacyba Cohen (1961:288; type-species by original designation Xyelacyba myersi Cohen).

Vo spine on snout. Ventral fins relatively close together, each with 2 rays (Fig. 26a); position variable, inserted between the level of the orbit and the rear of the maxillary. Spine on opercle long, extending beyond the rear margin of the head. Well-rleveloped spines at lower angle of preopercle. Eyes at surface of head, small. Deepest part of fish near rear of heacl. Developed rakers on first gill arch about 16. Median basibranchial tooth patches 2 or 3 . No dark spots on dorsal fin.

Atlantic and Pacific at abyssal depths. 
Possibly two or more species; only one of which is described, * $X$. myersi Cohen 1961.

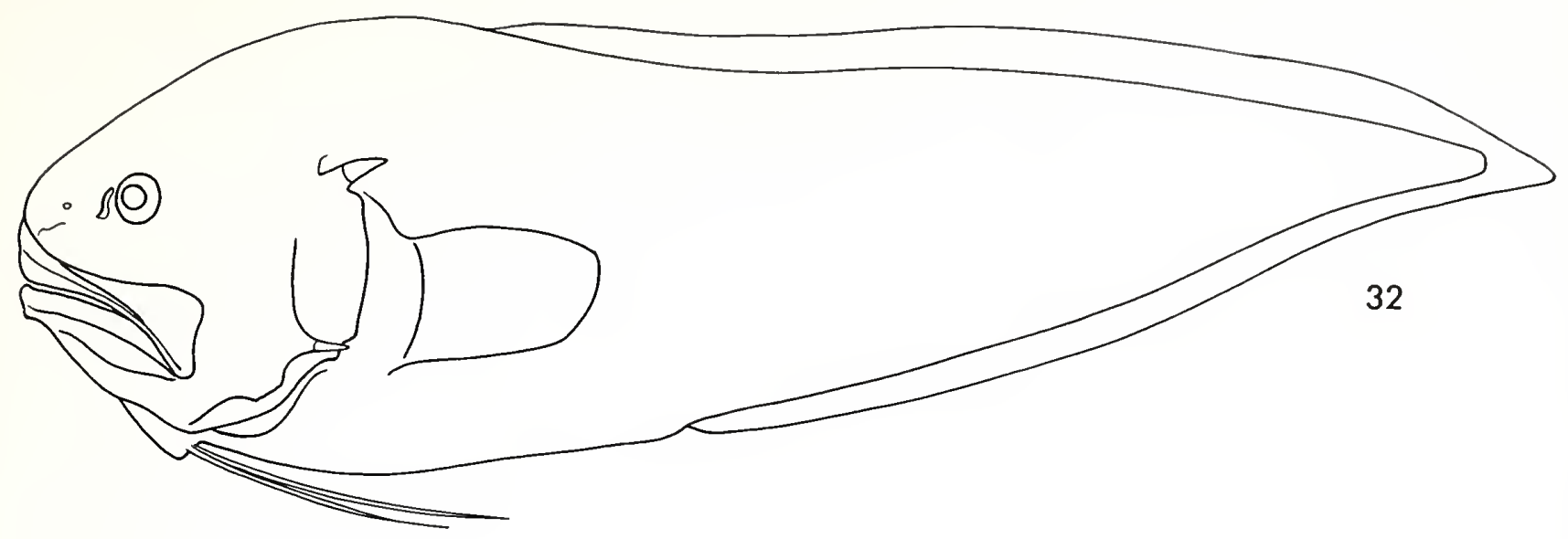

Neobythitini Radcliffe 1913

Symphysis of the cleithra and the pelvic girdle at about the level of the preopercle, well behind the eye. Ventral fins usually present, close together.

Further study will allow the partitioning of this tribe into groups of related genera. For the present, we note under those genera for which we have information their apparent relationships.

\section{Key to Genera of Neobythitini ${ }^{5}$}

1a. Ventral fins present, each with 1 or 2 well-developed rays $\ldots \ldots \ldots \ldots \ldots$

1b. Ventral fins absent or rudimentary, the rays represented by tiny stubs $\ldots \ldots \ldots \ldots$

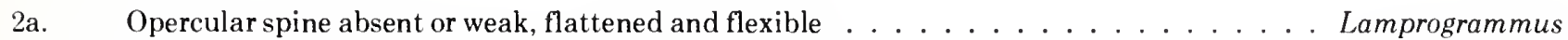

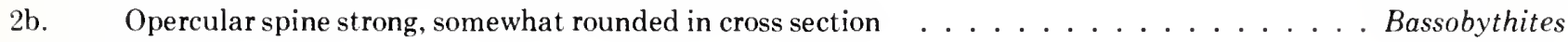

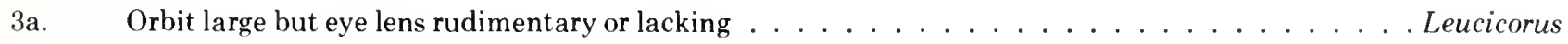

3h. Orbit large to small; developed lens present or eyes buried and not externally visible . . . . . . . 4

4a. Head massively inflated. Eyes not externally developed or very small $\ldots \ldots \ldots$. . . . . Typhlonus

4b. Head variously developed but not massively inflated. Eyes large to small, present externally . . . . . . 5

5a. Head about one-half or more than preanal length $\ldots \ldots \ldots \ldots$

5h. Head much less than one-half preanal length $\ldots \ldots \ldots \ldots$

6a. Developed gill rakers 3 or fewer. Vomerine teeth in a narrow row . . . . . . . . Enchelybrotula

6b. Developed gill rakers 5 or more. Vomerine teeth in a diamond-shaped patch $\ldots \ldots \ldots$

${ }^{5}$ Parabassogigas is entered twice in this key after couplet number 5. Porogadus is entered twice after couplet number 12. Dicrolene is entered twice after couplet number 20 . 


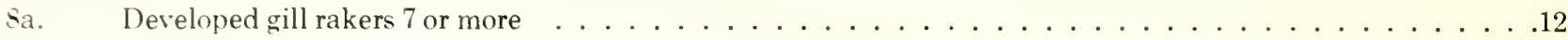

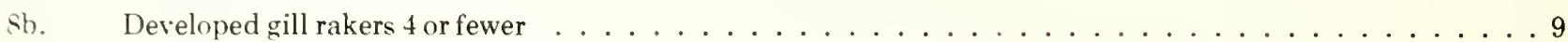

9a. Median basibranchial tooth patches 2. Preopercle with 2 or 3 spines at lower angle . . . . Pycnocraspedum

9h. Median basibranchial tooth patches 1 . Preopercle with 0 or 1 spine at lower angle ............. . .

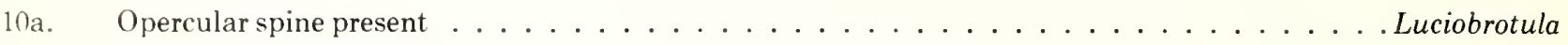

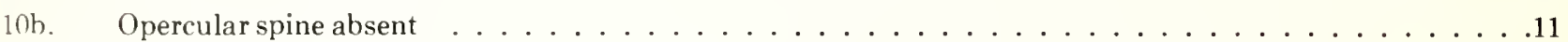

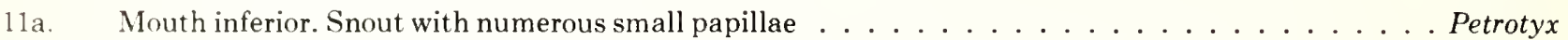

11b. Mouth terminal or lower jaw slightly longer. Snout without numerous small papillae . . . . . . Hypopleuron

12a. Opercular spine sometimes hidden but strong, narrow, usually rounded in cross section . . . . . . . 20

12b. Opercular spine absent or weak; if present rather broad, flattened, and flaplike or incorporated

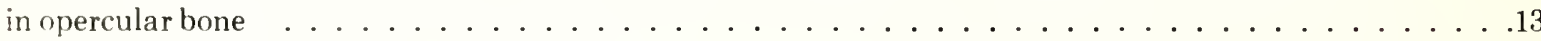

13a. Pectoral fin narrow and constricted proximally, originating on only part of pectoral peduncle; some of the rays greatly elongated, equaling one-half or more the standard length . . . . . Mastigopterus

13h. Pectoral fin not constricted proximally, originating on the entire pectoral peduncle; fin short or only lower rays greatly prolonged . . . . . . . . . . . . . . . . . . . . . . . . . .

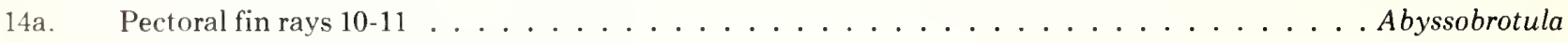

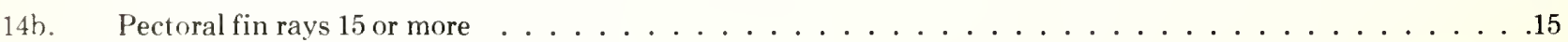

15a. Eye diameter equal to or greater than snout length . . . . . . . . . . . Glyptophidium

15h. Eye diameter less than snout length . . . . . . . . . . . . . . . . . . . . . . . . . .

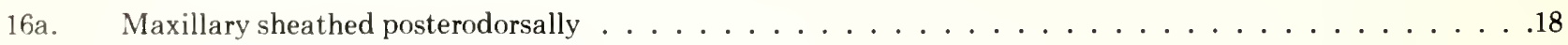

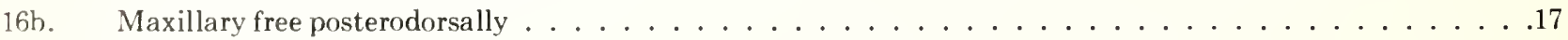

17a. All pectoral fin rays joined. Median basibranchial tooth patch 1 . Body depth at vent 10 or more

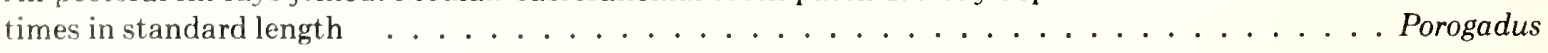

17h. Lower rays of pectoral fin free. Median basibranchial tooth patches 2 . Body depth at vent 9.5

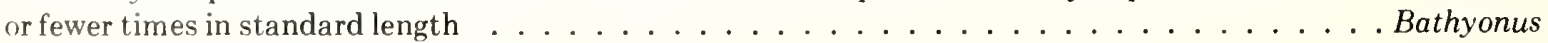


18a. Rear margin of maxillary at the level of or anterior to rear margin of eye

Alcockia

18b. Rear margin of maxillary well posterior to rear margin of eye

19a. Pectoral fin extending a short distance if at all beyond anus, not divided

Bassozetus

19b. Lower part of pectoral fin extending well beyond anus, or if rays not prolonged the fin is divided. Eretmichthys

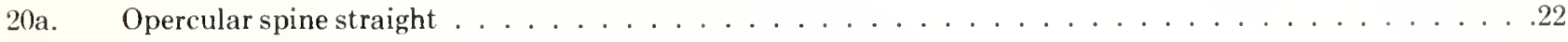

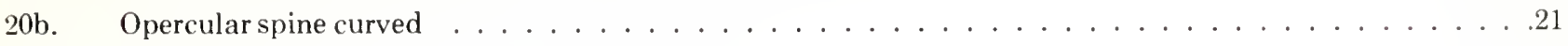

21a. Snout long, broad, and strongly depressed. Eye diameter one-third or less than snout length . . . . Penopus

21b. Snout short and blunt. Eye diameter equal to one-half or more than snout length ......... Dicrolene

22a. Pectoral fin entire; ventral fins with 1 or 2 rays in each . . . . . . . . . . . . . . . . . . . 24

22b. Lower rays of pectoral fin free; ventral fins with 2 rays in each . . . . . . . . . . . . . . . . . 23

23a. Eye diameter much less than one-half of snout length. Lower rays of pectoral fins shorter than upper rays. Pelvic fin rays flattened . . . . . . . . . . . . . . . . . . Holcomycteronus

23b. Eye diameter equal to one-half or more of snout length. Lower rays of pectoral fin longer than upper rays. Pelvic fin rays filamentous . . . . . . . . . . . . . . . . . . . . . . . . . . . . . . . . . . .

24a. Caudal fin with 5 or 6 rays. Body depth at vent 10 times or more in standard length . . . . . . Porogadus

24b. Caudal fin with 8 or more rays. Body depth at vent 8.5 times or less in standard length . . . . . . .25

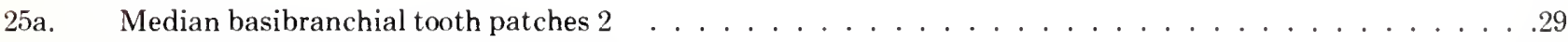

25b. Median basibranchial tooth patch 1 . . . . . . . . . . . . . . . . . . . . 26

26a. Ventral fin longer than head. Pectoral fin placed low on body, closer to belly than to midline . . Homostolus

26b. Ventral fin equal to or shorter than head. Pectoral fin inserted higher on body, closer to midline

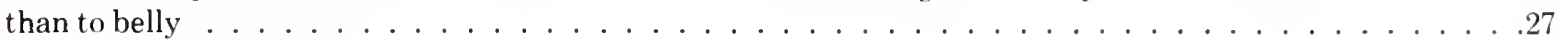

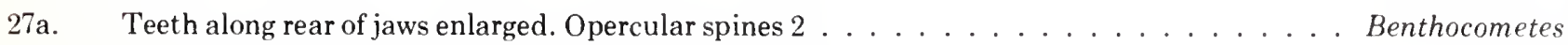

27b. Jaw teeth granular, small, and close-set. Opercular spine 1 . . . . . . . . . . . . . . . . . 28

28a. Ventral fin fleshy, reaching nearly to vent. Prominent dark spots on side of body and fins . . . Spottobrotula

28b. Ventral fin filamentous, falling far short of vent. No spots on body and fins . . . . . . . Monomitopus

29a. Teeth larger, needlelike, separate from each other . . . . . . . . . . . . . . . Epetriodus

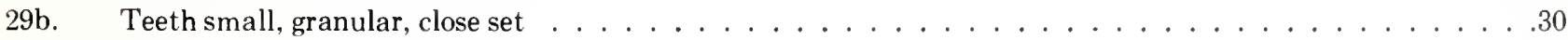


30b. Ventral rays 2 in each fin

31a. Eve diameter about equal to or greater than snout length. Many species with prominent spots,

blotches, or bands

Neobythites

31b. Eve diameter less than snout length. No spots, blotches, or bands

32a. Anterior nostril with a thick, fleshy raised rim (Fig. 33)

Parabassogigas

32b. Anterior nostril a simple pore or with a thin tube, but not as above

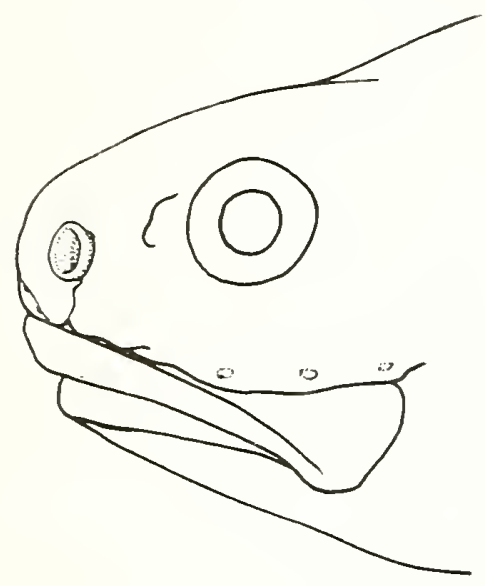

Figure 33.-Parabassogigas head. Note the thick, fleshy, raised rim of the anterior nostril.

33a. Snout notably inflated. Maxillary sheathed. Developed gill rakers 12 or more Barathrodemus

\section{Abyssobrotula Nielsen}

(Fig. 34)

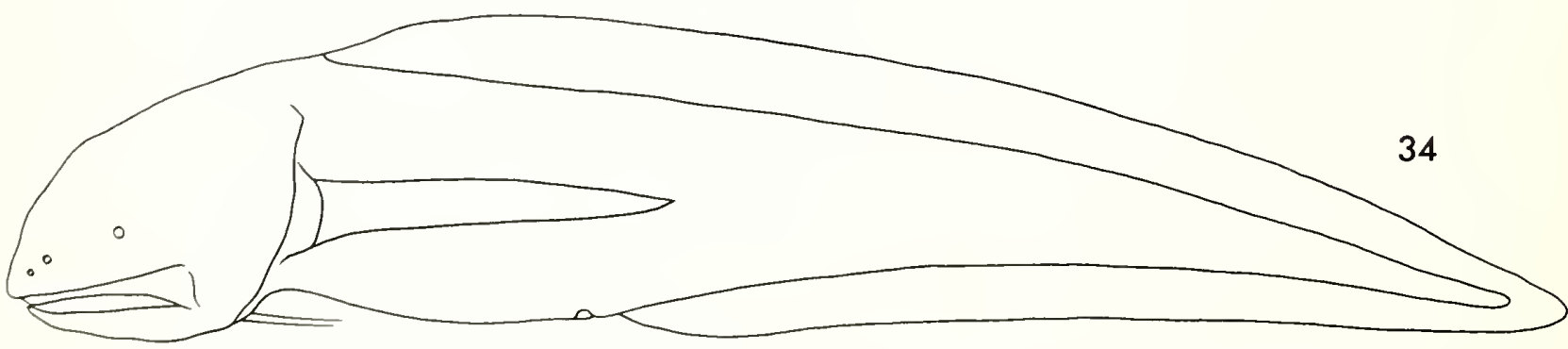

Abyssobrotula Nielsen (1977:41; type-species by original designation Abyssobrotula galatheae Nielsen).

Snout swollen. Mouth slightly inferior. Eyes small. Opercular spine poorly developed. Basibranchial with 2 median and 1 pair of tooth patches. Vomer with a V-shaped tooth patch. Anterior gill arch with 8 to 11 long rakers. Pectoral fin with 10 or 11 rays; extending beyond anus. Ventral fins with 2 rays in each. Precaudal vertebrae 18 to 21 . Branchiostegal ravs 7 or 8 .

Probably related to Enchelybrotula and Barathrites.

Circumglobal at abyssal and hadal depths. A specimen trawled from the Puerto Rico trench at 8,370 m (Staiger 1972) is the deepest recorded fish (as Bassogigas profundissimus).

A single species, *A. galatheae Nielsen 1977. 


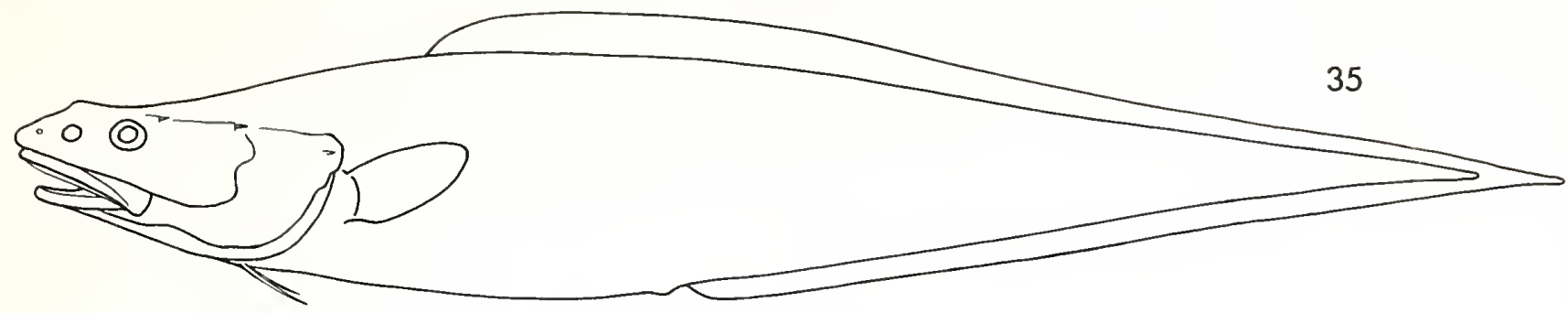

Alcockia Goode and Bean (1896:329; type-species by original designation Porogadus rostratus Günther).

Head depressed. Eye diameter about 2 times in snout length. Opercular spine flat and weak. Spines on head sharp and well-developed, particularly behind posterior nostril, above eye, and above cheek. Suborbital bones membranous. Maxillary strongly sheathed posterodorsally. Median basibranchial tooth patches 2. Developed rakers on anterior arch 7 . Branchiostegal rays 8 . Ventral fins with 2 rays in each. Precaudal vertebrae 15 or 16.

Possibly related to Porogadus, some species of which it resembles in having similar armature on the head. There are, however, numerous differences between the two genera.

Known from 7 specimens caught at abyssal depths between the Celebes and Madagascar.

A single species, ${ }^{*}$ A. rostrata (Günther 1878 ).

\section{Barathrites Zugmayer}

(Fig. 36)

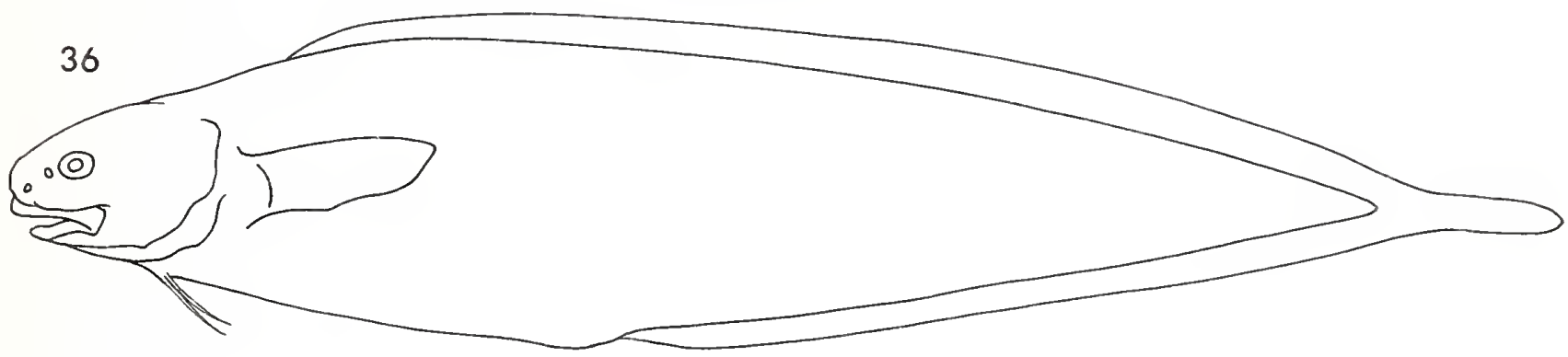

Barathrites Zugmayer (1911:11; type-species by monotypy Barathrites iris Zugmayer).

Ventral fins with 2 rays in each. Caudal fin rays 8. Abdomen long; head short, about 3 times in preanal distance. Tips of pectorals falling well short of vent. Eyes small. Median basibranchial tooth patch 1 , small. Vomerine teeth in a diamond-shaped patch. Branchiostegal rays 7. Developed gill rakers on first arch 5 to 7. Opercular spine short, sharp, rounded in cross section. Precaudal vertebrae 18.

Possibly related to Abyssobrotula and Enchelybrotula, which also have 7 branchiostegal rays and to Parabassogigas. with which it shares a high number of precaudal vertebrae.

Abyssal from the tropical Atlantic and Pacific.

This genus is being studied by D. M. Cohen. Three described species, of which probably only two are valid: ${ }^{*} B$. iris Zugmayer $1911\left({ }^{*} B\right.$. abyssorum Roule 1916 is probably a synonym), and ${ }^{*} B$. parri Nybelin 1957.

\section{Barathrodemus Goode and Bean}

(Fig. 37)

Barathrodemus Goode and Bean (1883:200; type-species by monotypy Barathrodemus manatinus Goode and Bean).

Ventral fins with 2 rays in each. Caudal fin rays 8. Abdomen short, pectoral fin reaching nearly to vent or beyond. Snout inflated. Maxillary strongly sheathed. Median basibranchial tooth patches 2. Vomerine tooth patch triangular. Branchiostegal rays 8. Developed gill rakers on first arch 12 to 15 . Opercular spine short, sharp. Precaudal vertebrae 12 to 14 . Pectoral fin rays 19 to 25 .

Possibly related to Parabassogigas.

Continental slopes of the tropical Atlantic and western Pacific. 


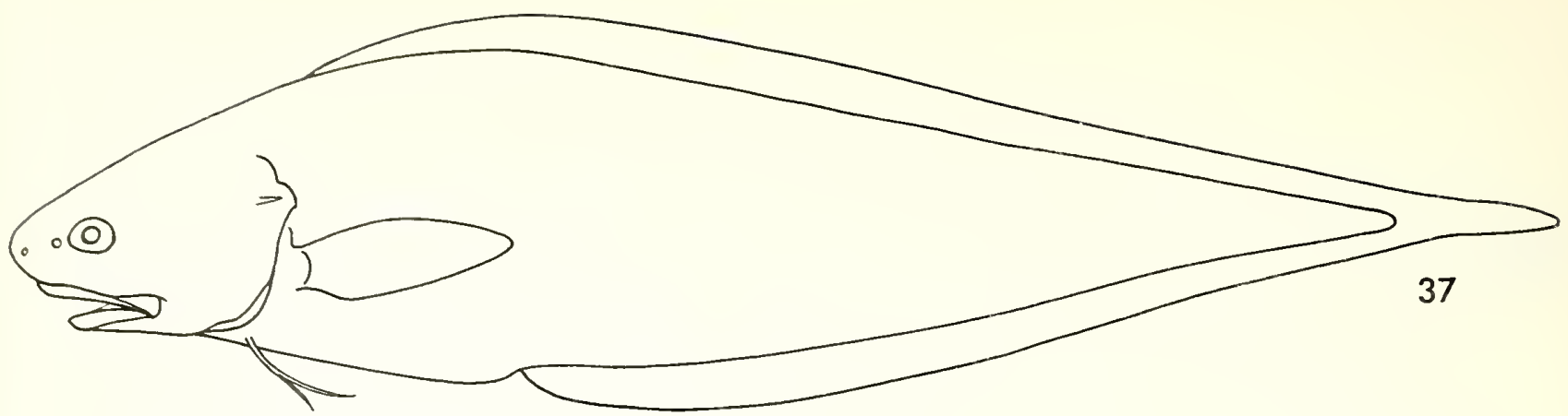

Three nominal species may be assigned to this genus, which is being studied by D. M. Cohen: ${ }^{*} B$. manatinus Goode and Bean $1883,{ }^{*} B$. microps Parr 1933 , and ${ }^{*} B$. nasutus Smith and Radcliffe in Radcliffe 1913.

\section{Bassobythites Brauer}

(Fig. 38)

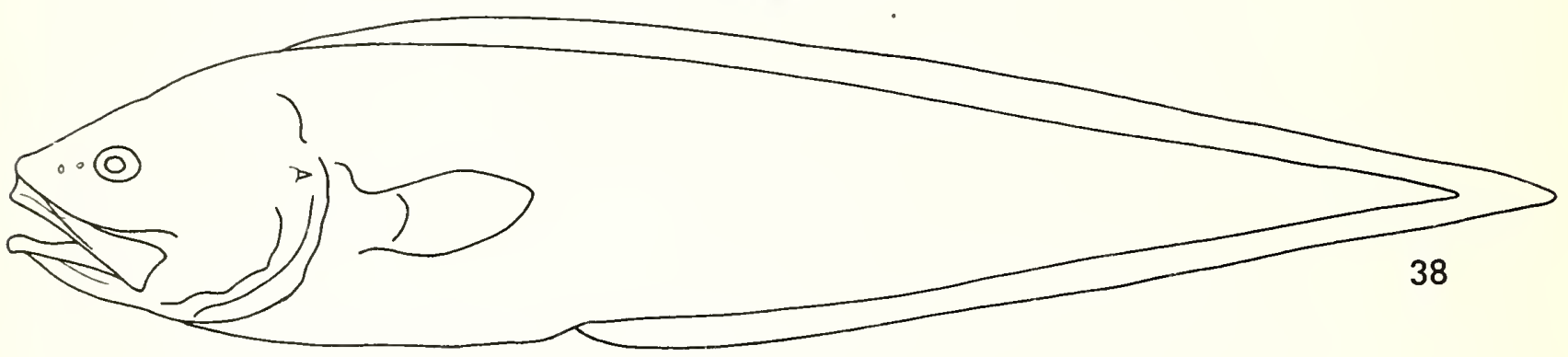

Bassobythites Brauer (1906:307; type-species by monotypy Bassobythites brunswigi Brauer).

Ventral fins absent. Median basibranchial tooth patch 1. Branchiostegal rays 8. Caudal fin rays 8. Mouth terminal. Teeth granular. Precaudal vertebrae 13. Opercular spine somewhat rounded in cross section, sharp pointed. Head bones relatively well ossified. Lateral line similar to that of Lamprogrammus but outer covering of scales more strongly adherent: marked externally in several specimens by a single series of pores with fleshy raised rims, extending along the body a short distance beneath the dorsal profile. Scales on body large and small.

Closelv related to and possibly identical with Lamprogrammus.

Indian Ocean, western Pacific, and eastern Atlantic.

Two nominal species: ${ }^{*} B$. brunswigi Brauer 1906, and *B. macropterus (Smith and Radcliffe in Radcliffe 1913).

Bassogigas Goode and Bean

(Fig. 39)

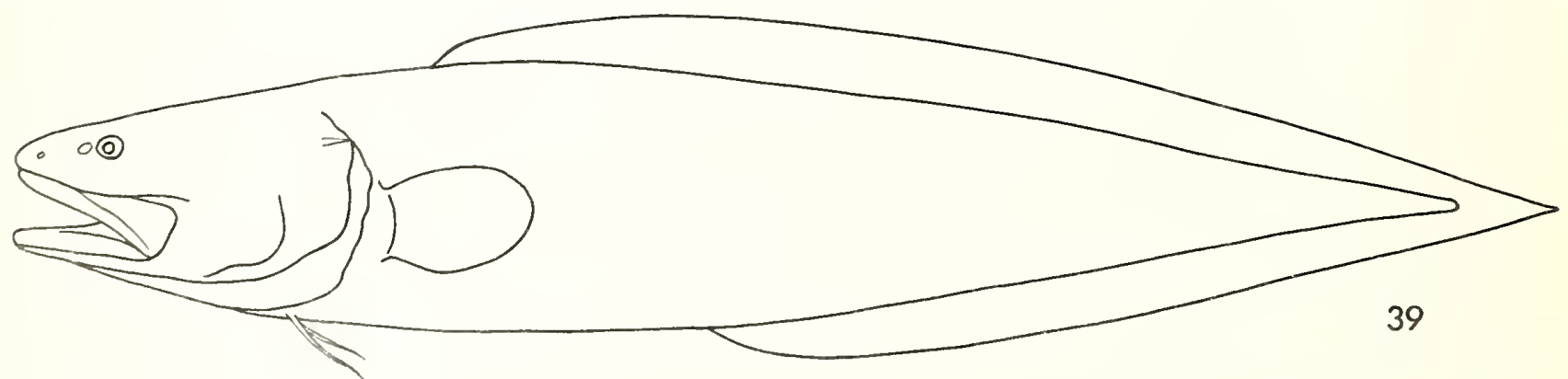

Bassogigas Gonde and Bean (1896:328; type-species by subsequent designation of Jordan and Evermann 1896, Bassogigas gillii Gonde and Bean).

Snout much longer than eye. Opercular spine strong. Median basibranchial tooth patches 2. Vomerine tooth patch V- 
shaped. Developed rakers on first gill arch 7 to 9 . Pectoral fin short and rounded, with 27 to 31 rays. Ventral fins with 2 rays in each. Branchiostegal rays 8 . Precaudal vertebrae 15 or 16 . A distinct dorsal lateral line.

Related to Holcomycteronus.

Tropical Atlantic at bathyal and abyssal depths.

Although a number of species have been referred to Bassogigas, Neilsen (manuscr. in prep.) has restricted the genus to the type-species, * $B$. gillii Goode and Bean 1896.

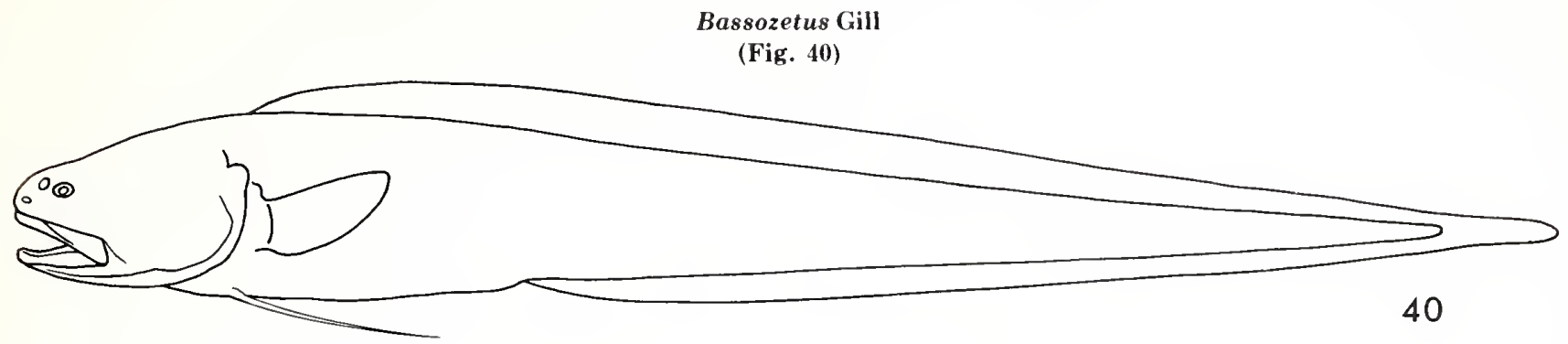

Bassozetus Gill (1884:259; type-species by monotypy Bassozetus normalis Gill).

Pterodicromita Fowler (1925:5; type-species by original designation Sirembo oncerocephalus Vaillant).

Mouth terminal. Snout somewhat inflated. Eye diameter 2.5 or more times in snout. Opercular spine weak or absent. Preoperculum unarmed and posteriorly expanded, in most species reaching almost to the posterior margin of operculum. Median basibranchial tooth patch 1 (except 0 in $B$. zenkevitchi). Developed rakers on anterior gill arch 12 to 16 . Pseudobranchial filaments 2. Pectoral fin short, not reaching far beyond anus, with 23 to 31 rays. Ventral fins with 1 ray in each. Precaudal vertebrae 11 to 16 . Lateral line indistinct.

Very closely related to Eretmichthys.

A rather common circumtropical genus at deep-bathyal and abyssal depths.

The genus requires revision. Nine nominal species and at least one undescribed: $\quad * B$. compressus (Günther 1878 ), ${ }^{*} B$. elongatus Smith and Radcliffe in Radcliffe 1913, ${ }^{*}$ B. glutinosus (Alcock 1890a), B. nasus Garman $1899,{ }^{*} B$. normalis Gill 1884, ${ }^{*} B$. oncerocephalus (Vaillant 1888$),{ }^{*} B$. robustus Smith and Radcliffe in Radcliffe 1913 , ${ }^{*} B$. taenia (Günther 1887), and ${ }^{*} B$. zenkevitchi Rass 1955 .

Bathyonus Goode and Bean

(Fig. 41)

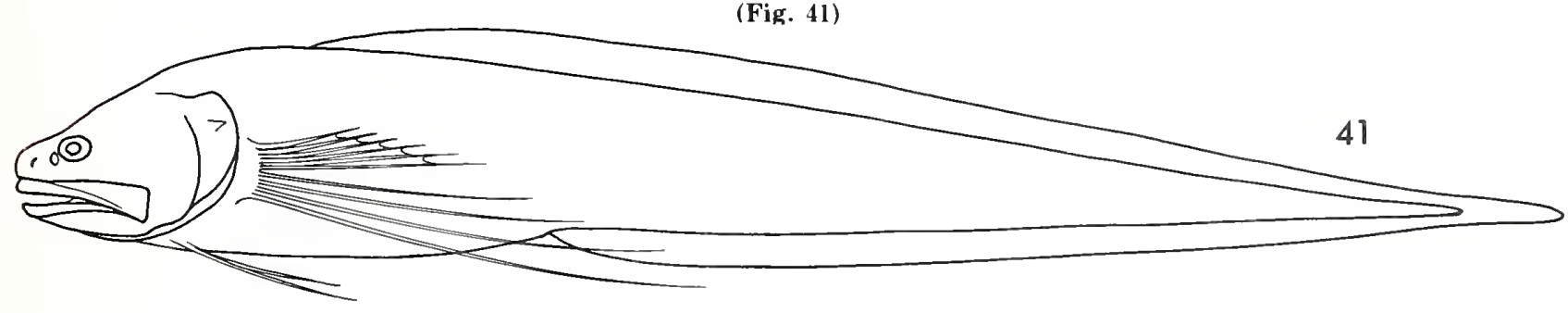

Bathvnectes Günther (1878:20; type-species by subsequent designation of Jordan 1919, Bathynectes laticeps Günther ${ }^{6}$; preoccupied by Bathynectes Stimpson 1870 in Crustacea).

Bathyonus Goode and Bean (1886:603; replacement name for Bathynectes Günther, takes the same type-species). Mixonus Günther (1887:108; type-species by monotypy Bathynectes laticeps Günther).

Nematonus Günther (1887:114; type-species by monotypy Bathyonus pectoralis Goode and Bean 1886).

Body depth 9.5 or fewer times in standard length. Head length equal to approximately one-half preanal length. No prominent spines on top or side of head. Median basibranchial tooth patches 2 . Developed rakers on first gill arch 10 or more. Caudal fin rays 6 . Pectoral fin with lower rays free and stronger and longer than those above. Ventral fins with 2 rays in each. Branchiostegal rays 8 . Precaudal vertebrae 17 to 19.

For possible relationships see Porogadus.

Circumtropical at abyssal depths.

\footnotetext{
${ }^{6}$ The name compressus is given by Jordan and Evermann (1898:2507) in pa renthesis after the name and citation for Bathynectes Günther (which they list in the synonymy of Bassozetus). We do not accept Jordan and Evermann's action as constituting designation of a type species for Bathynectes for reasons discussed by Follett and Cohen (1958) and China (1962).
} 
Three nominal species may be assigned to this genus, which is being studied by D. M. Cohen: * B. caudalis (Garman 1899). ${ }^{*} B$. laticeps (Günther 1878), and ${ }^{*} B$. pectoralis (Goode and Bean 1886).

\section{Benthocometes Goode and Bean}

(Fig. 42)

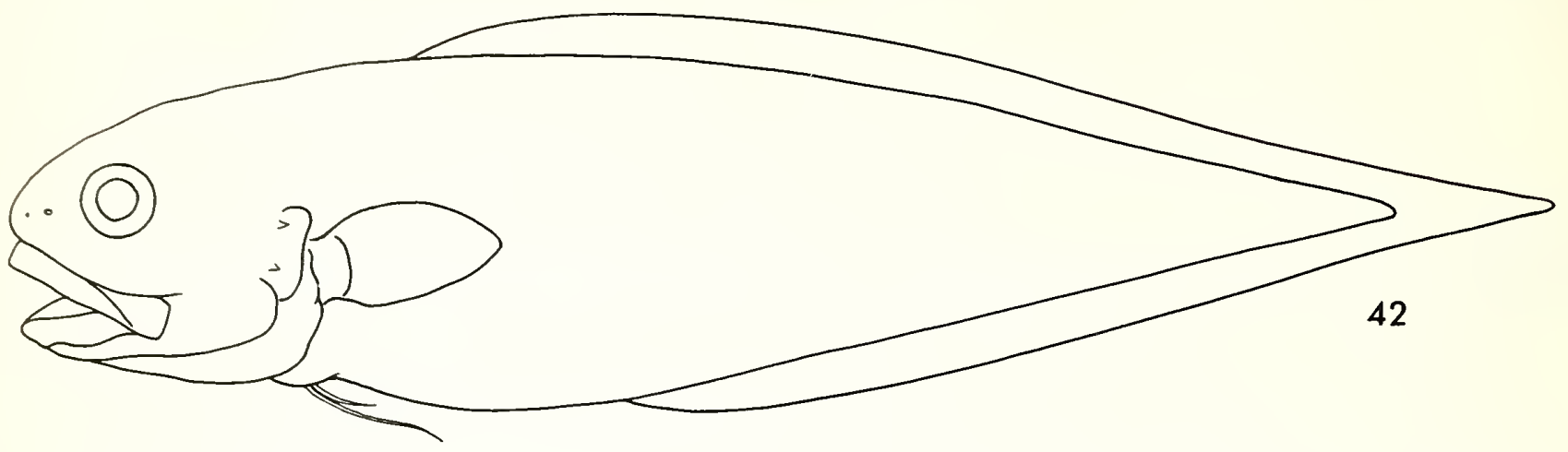

Benthocometes Goode and Bean (1896:327; type-species by subsequent designation of Jordan and Evermann 1896, Nenbithites robustus (roode and Bean).

Body rather short and stubby; depth at vent 4 or 5 times in standard length. Mouth terminal. Eye diameter about equal to or greater than snout length. Opercle with 2 posteriorly directed spines. Median basibranchial tooth patch single. Teeth along rear of jaws somewhat enlarged. Vomerine tooth patch without arms. Developed rakers on first gill $\operatorname{arch} 8$ to 11. Pseudobranchial filaments about 5. Pectoral fin rays 27 to 30 . Caudal fin rays 10 or 11 . Ventral fins with 2 ravs in each. Branchiostegal rays 8 . Precaudal vertebrae 11 or 12 . Lateral line distinct.

Perhaps related to Neobythites.

Tropical Atlantic and Mediterranean at depths of 500 to $1,000 \mathrm{~m}$.

A single species was recognized by Bougis and Ruivo (1954) in their study of the genus, ${ }^{*} B$. robustus (Goode and Bean 1886) (synonyms are Pteridium armatum Doderlein 1886 and Sirembo muraenolepis Vaillant 1888).

Dicrolene Goode and Bean

(Fig. 43)

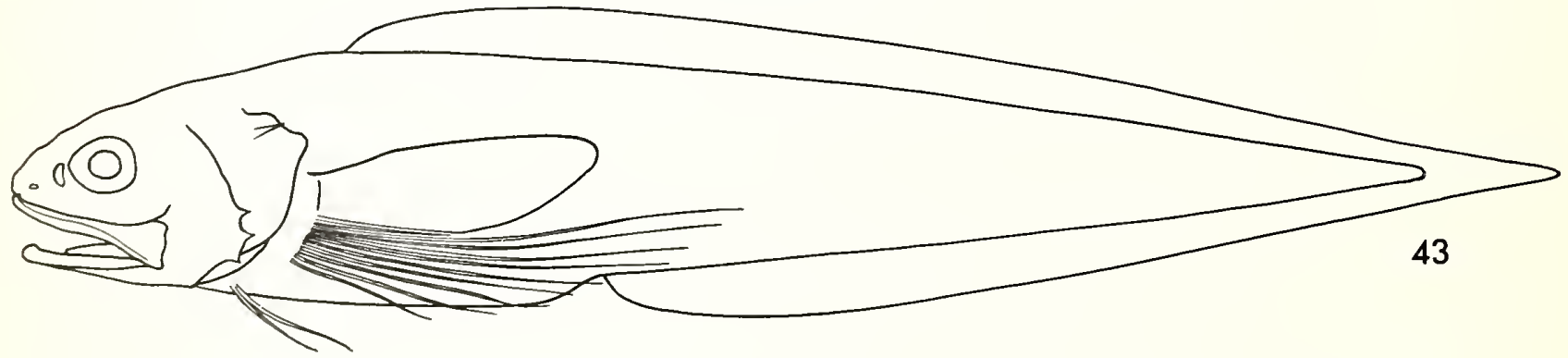

Dicrolene Goode and Bean (1883:202; type-species by monotypy Dicrolene intronigra Goode and Bean).

Pteroidonus Günther (1887:106; type-species by monotypy Pteroidonus quinquarius Günther).

Paradicrolene Alcock (1889:387; type-species by monotypy Paradicrolene multifilis Alcock).

Brachydicrolene Norman (1939:86; type-species by original designation Paradicrolene nigricaudis Alcock).

Snout rather blunt. Eyes large, equal to one-half or more than snout length; 4 to 8.3 times in head length. Opercular spine strong and straight (except curved in D. kanazawai). Margin of preoperculum usually with 3 sharp spines. Median basibranchial tooth patches 1 or 2; a single paired set of tooth patches (except 0 in $D$. kanazawai). Developed gill rakers on anterior arch 7 to 15 . Pectoral fin rays 22 to 33 ; the lower 5 to 11 rays free and longer than the upper rays. Ventral fins with 2 rays in each. Precaudal vertebrae 13 to 16.

Apparently related to Mastigopterus.

Common fishes found in tropical and temperate seas at bathyal and upper abyssal depths (about 500-3,200 m).

Dicrolene as presently characterized is highly variable. A much needed revision may show that more than one genus should be recognized. Thirteen described species may be ascribed to this genus; an undescribed one is known (Nielsen et 
al., manuscr.): ${ }^{*} D$. filamentosa Garman $1899,{ }^{*} D$. gregoryi Trotter $1926,{ }^{*} D$. hubrechti Weber $1913,{ }^{*} D$. intronigra Goode and Bean $1883,{ }^{*} D$. kanazawai Grey $1958,{ }^{*} D$. longimana Smith and Radcliffe in Radcliffe $1913,{ }^{*} D$. multifilis (Alcock 1889), * ${ }^{*}$. nigra Garman 1899, ${ }^{*} D$. nigricaudis (Wood-Mason and Alcock 1891), ${ }^{*} D$. pullata Garman $1899,{ }^{*} D$. quinquarius (Günther 1887), ${ }^{*} D$. tristis Smith and Radcliffe in Radcliffe 1913, and ${ }^{*} D$. vaillanti (Alcock 1890b).

Enchelybrotula Smith and Radcliffe

(Fig. 44)

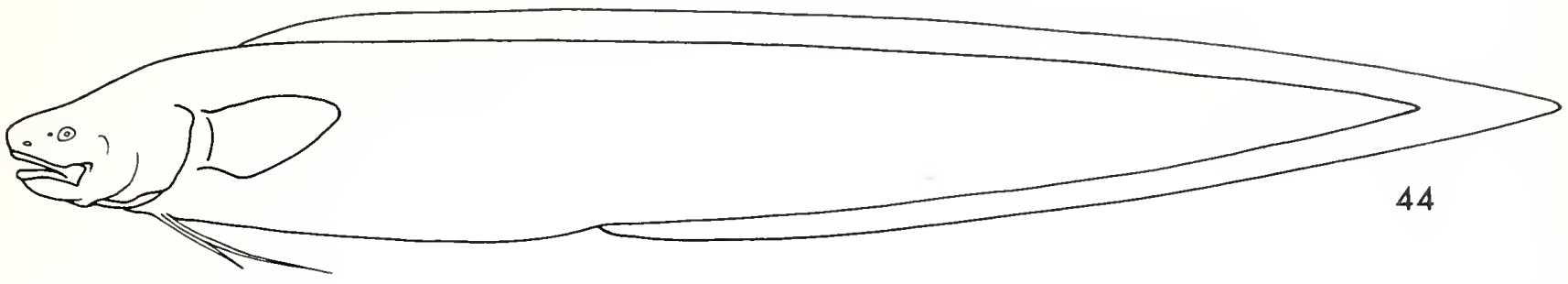

Enchelvbrotula Smith and Radcliffe in Radcliffe (1913:154; type-species by original designation Enchelybrotula paucidens Smith and Radcliffe).

Ventral fins with 2 rays in each. Caudal fin rays 8. Body long and compressed. Abdomen long, head 3 times or more in preanal distance. Eves small. Jaw teeth sharp-pointed, compressed, in a single row. Median basibranchial tooth patches 2. Vomerine teeth in a narrow row. Branchiostegal rays 7. Gill rakers on the first arch short, spiny tubercles. Opercular spine short, sharp, rounded in cross section. Precaudal vertebrae 22.

Possibly related to Barathrites, which also has 7 branchiostegal rays and to Parabassogigas, with which it shares a high number of precaudal vertebrae. Although Barathrodemus has a shorter body it is similar in appearance.

Abvssal from the Bay of Bengal to the Gulf of Panama.

A single described species, ${ }^{*}$ E. paucidens Smith and Radcliffe in Radcliffe 1913, and possibly an unnamed one. This genus is being studied by D. M. Cohen.

\section{Epetriodus New Genus}

Type species Epetriodus freddyi new species.

Body relatively short, depth at vent between 5 and 6 times in standard length; preanal length about 2.3 times in standard length. Head somewhat longer than one-half of preanal distance, about 4 times in standard length. Lower jaw slightly included. Body completely covered with small cycloid scales in regular rows; head completely scale covered. Eye diameter about one-half of snout length, 7 to 8 times in head length. Anterior nostril a prominent round pore in midsnout. posterior nostril larger, crescent-shaped, in front of eye. Opercle bearing a short, sharp spine, which does not reach the rear margin of the head. Preopercle lacking spines. Branchiostegal rays 8 . Developed rakers on first arch at least 20, grading into tubercles at the anterior end of the lower arm of the first arch. Pseudobranch with 2 filaments. Maxillary extending far beyond the rear margin of the eye, dorsal margin free posteriorly. Jaw teeth sharp-pointed and needlelike, not close set and granular; in two series on the premaxillary, the outer teeth larger, and on the dentary, the inner teeth larger. Teeth present also on vomer and palatines. Median basibranchial tooth patches 2; no paired basibranchial tooth patches.

Lateralis system on head with obvious pores. Lateral line on body deciduous but apparently in three series.

Pectoral rays 25 to 29; the fin is naked, broad, and rounded, extending to about the level of the vent. Ventral fins with 2 rays in each, inserted behind the symphysis of the cleithra by a distance about equal to the horizontal diameter of the eye; the rays are bound together proximally and covered with thick skin, free and filamentous distally. Median fins covered with translucent, naked skin. Caudal fin rays 8 .

Precaudal vertebrae 12 or 13 . Neural spine on first centrum shorter than those following. Neural spines pointed, those on middle precaudal centra depressed. The posterior face of centrum 4 and the anterior face of centrum 5 are expanded. Centra 1 and 2 appear to lack ribs (based on X-ray photographs); ribs originate directly on centra 3 to 7 and on parapophyses from subsequent precaudal centra. Epipleural ribs are present.

Epetriodus appears similar to Holcomycteronus in body and head shape. Other resemblances are in having 2 median basibranchial tooth patches, 8 branchiostegal rays, 8 caudal fin rays, the apparent absence of ribs on the first 2 centra, a short, sharp opercular spine, and small eyes. Epetriodus is more specialized in its dentition and modified fourth and fifth centra (a condition we have noted on X-ray photographs of all 3 specimens and which in our experience is unique in the order); Holcomycteronus is more specialized in its modified paired fins and its very deepwater habitat.

Tropical and subtropical southwest Indian Ocean at depths ranging from about 1,000 to $1,750 \mathrm{~m}$. 
The name Epetriodus is derived from the Greek epetrion $=$ needle and odous $=$ tooth, and refers to the distinctive teeth of this genus.

A single species, described below.

Epetriodus freddyi New Species

(Fig. 45)

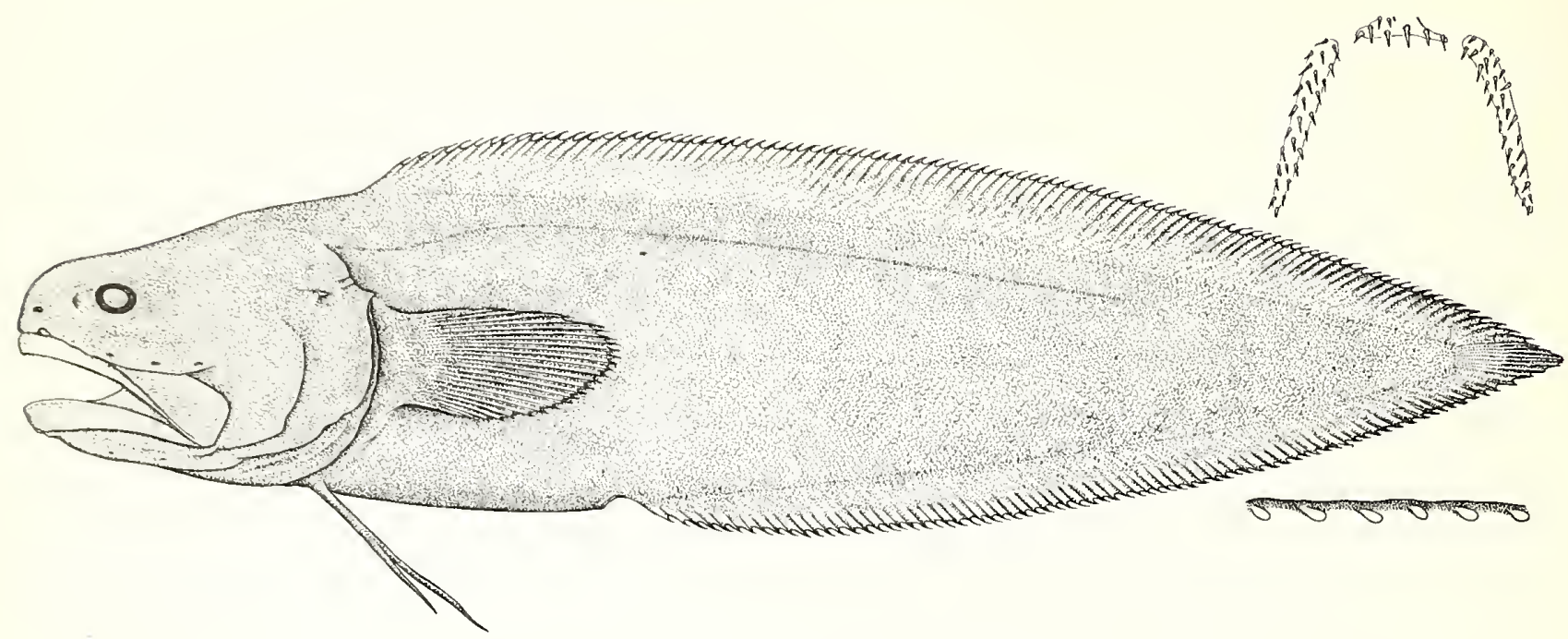

Figure 45.-Epetriodus freddyi; holytype, U.S. National Museum 206942. Upper right, tooth bearing surfaces of vomer palatines; lower right, details of dorsal lateral line from South African Museum 27745. Drawn by Keiko Hiratsuka Moore.

Table 2.-Counts and measurements in millimeters for Epetriodus freddyi n.sp. Numbers in parenthesis are percent of standard length.

\begin{tabular}{|c|c|c|c|}
\hline & $\begin{array}{c}\text { USNM } \\
206942 \\
\text { Holotype }\end{array}$ & $\begin{array}{c}\text { SAM } \\
27745 \\
\text { Paratype }\end{array}$ & $\begin{array}{l}\text { MNHM } \\
\text { 1977-303 } \\
\text { Paratype }\end{array}$ \\
\hline Dorsal fin rays & 95 & 96 & 97 \\
\hline Anal fin rays & 76 & 74 & 76 \\
\hline Pectoral fin rays & 25 & 29 & 25 \\
\hline Vertebrae & $12+42=54$ & $13+40=53$ & $13+40=53$ \\
\hline Lateral scale rows & $? 140$ & $? 146$ & - \\
\hline \multicolumn{4}{|l|}{ Gill rakers on 1st arch } \\
\hline Upper arm & $\begin{array}{c}5 \text { short }+ \\
2 \text { long }\end{array}$ & $\begin{array}{c}6 \text { short }+ \\
2 \text { long }\end{array}$ & $\begin{array}{c}5 \text { short }+ \\
2 \text { long }\end{array}$ \\
\hline Angle & 1 long & 1 long & 1 long \\
\hline Lower arm & $\begin{array}{r}19 \text { long }+ \\
4 \text { short }\end{array}$ & $\begin{array}{r}19 \text { long + } \\
4 \text { short }\end{array}$ & $\begin{array}{r}18 \text { long + } \\
7 \text { short }\end{array}$ \\
\hline Standard length & 215 & 176 & 170 \\
\hline Preanal & $94.3(43.9)$ & $76.8(43.6)$ & $77.0(45.3)$ \\
\hline Predorsal & $56.1(26.1)$ & $44.1(25.1)$ & $45.5(26.8)$ \\
\hline Body depth at vent & $42.5(19.8)$ & $31.8(18.1)$ & $31.6(18.6)$ \\
\hline Head length & $55.0(25.6)$ & $42.1(23.9)$ & $43.9(25.8)$ \\
\hline Snout length & $16.4(7.6)$ & $10.9(6.2)$ & $12.2(7.2)$ \\
\hline Upper jaw length & $36.0(16.7)$ & $27.0(15.3)$ & $28.4(16.7)$ \\
\hline Maxillary depth at end & $8.5(3.9)$ & $6.2(3.5)$ & $6.5(3.8)$ \\
\hline Eye diameter, horizontal & $6.9(3.2)$ & $5.8(3.3)$ & $5.8(3.4)$ \\
\hline Interorbital, pigmented & $18.7(8.7)$ & $14.8(8.4)$ & $13.7(8.1)$ \\
\hline Pectoral fin length & $31.5(14.6)$ & $26.7(15.2)$ & $24.7(14.5)$ \\
\hline Pectoral peduncle depth & $14.2(6.6)$ & $10.9(6.2)$ & $11.4(6.7)$ \\
\hline Ventral fin length & $29.0(13.5)$ & $21.2(12.0)$ & - \\
\hline $\begin{array}{l}\text { Symphysis of cleithra } \\
\text { to ventral fin origin }\end{array}$ & $7.0(3.3)$ & $5.7(3.2)$ & $6.0(3.5)$ \\
\hline
\end{tabular}

Counts and measurements are presented in Table 2.

A single, rayless pterygiophore precedes the dorsal fin. Developed (long) gill rakers close-set and compressed, the longest about equal in length to the eye diameter; longest filaments on first arch notably shorter. 
Lateralis canals on head with the following pore counts: lateral 1, supraorbital 1, infraorbital 5, and preoperculomandibular 8. All three lateral lines on the body are present (in part) only on SAM 27745. The dorsalmost lateral line parallels the base of the dorsal fin for about three-fourths the length of the body and consists of a narrow, naked tube with a series of about 30 pores, which are at the ends of short, ventrally directed tubes anteriorly and on the main canal posteriorly. Remnants are present of a second, naked, pore-bearing lateral line beginning at about the tip of the pectoral fin and extending posteriorly in the midline at least as far as does the dorsal line.

The presence of a third line is suggested by the presence of several naked pores on the side over the anal fin base near the anus.

The body is pale brown; in the holotype the pectoral fins are slightly darker, as are the tips of the ventrals and the median fins; the paratypes have all fins notably darker, as are the lateral lines; the head of SAM 27745 is dusky.

Observations were made of the body cavities and associated areas of the holotype and of SAM 27745. The lining of the peritoneal cavity is black, as is the intestinal tract anterior to the pyloric region. The guts are pale posteriorly. Pyloric caeca are absent. A prominent liver is present and reaches to or beyond the posterior curve of the stomach. The rear part of the intestine is narrow, thin-walled, and highly convoluted. The swim bladder is relatively thick walled and large, extending to nearly the end of the body cavity. The kidney is a prominent bulky mass of tissue located dorsal to the rear end of the peritoneal cavity and posterior to the swim bladder; it is soft and rather glandular in appearance and has a pair of lobes, each of which extends anteriorly lateral to the posterior end of the swim bladder. In both specimens examined the gonads are paired, scarcely developed strands of light colored tissue, perhaps ovaries.

Holotype: U.S. National Museum 206942; lat. $21^{\circ} 18^{\prime} \mathrm{S}$, long. $36^{\circ} 18^{\prime} \mathrm{E}, 1,510-1,600 \mathrm{~m}$; Anton Brunn cruise 8, stn. $399 \mathrm{C}$, shrimp trawl; 2 Oct. 1964. Paratypes: Museum National d'Histoire Natural 1977-303; lat. $18^{\circ} 00^{\prime} \mathrm{S}$, long. $43^{\circ} 00^{\prime} \mathrm{E}$, 1,715-1,750 m; A. Crosnier coll., Madagascar Channel 127; trawl; 16 Jan. 1975. South African Museum 27745 ; lat. $28^{\circ} 37.8^{\prime} \mathrm{S}$, long. $32^{\circ} 38.4^{\prime} \mathrm{E}, 1,000-1,200 \mathrm{~m}$; Meiring Naude SM107; 25 May 1976.

This species is named for Professor N. B. (Freddy) Marshall in recognition of his contributions to knowledge of the biology of deepsea fishes.

\section{Eretmichthys Garman}

(Fig. 46)

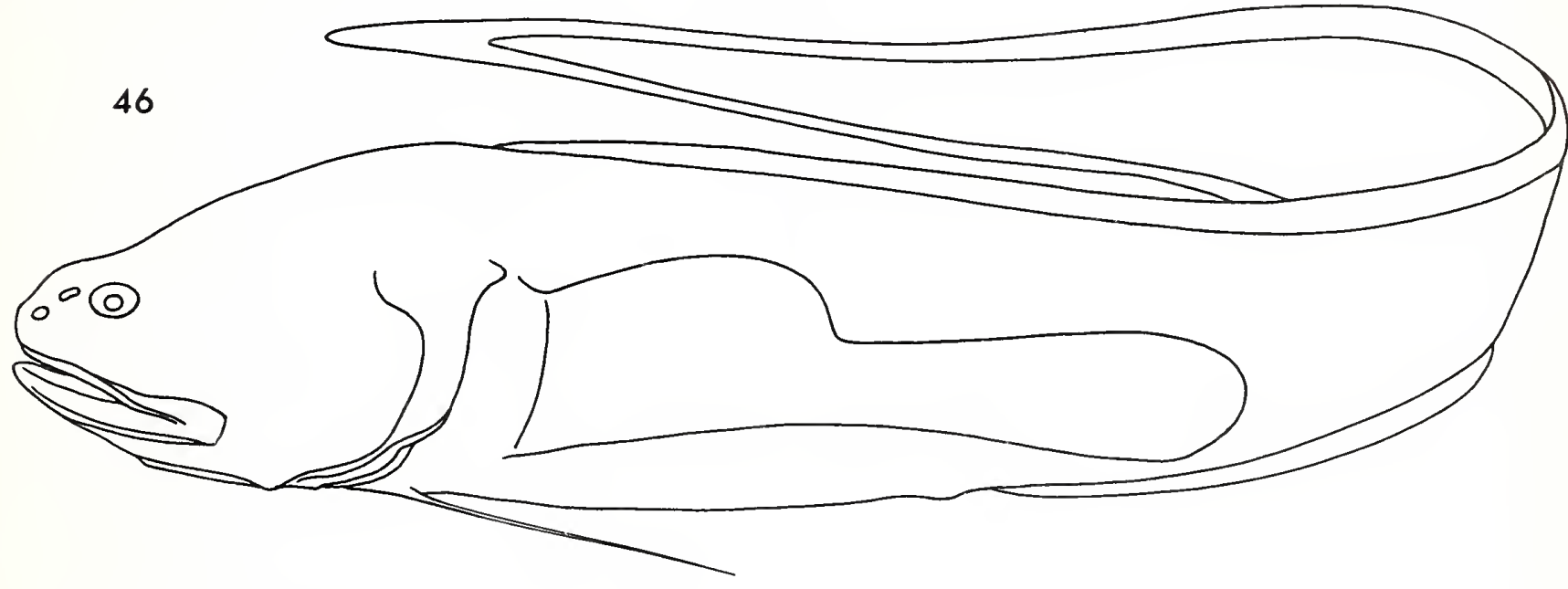

Eretmichthys Garman (1899:164; type-species by subsequent designation of Jordan (1920), Eretmichthys pinnatus Garman).

Mouth terminal. Eye diameter 1.5 or more times in snout. Preoperculum and operculum lacking spines. Preoperculum posteriorly expanded, reaching almost to the posterior margin of operculum. A single median basibranchial tooth patch. Developed rakers on anterior arch 15 to 19 . Pseudobranchial filaments 2 . Pectoral fin divided, with the rays of the lower part extending well behind anus; a total of 25 to 29 rays. Ventral fins with 1 ray in each. Precaudal vertebrae 14 or 15. Lateral line indistinct.

Closely related to Bassozetus. The only difference seems to be the presence in Eretmichthys of oarlike, prolonged lower pectoral fin rays. In specimens with damaged pectorals it is hardly possible to distinguish between the two genera. Each of the two syntypes of $E$. ocella has damaged pectoral fin rays and therefore may be specimens of Bassozetus.

Rarely caught fishes, taken at bathyal and upper abyssal depths in the Indian and Pacific Oceans.

Three nominal species: ${ }^{*} E$. ocella Garman $1899,{ }^{*} E$. pinnata Garman 1899 , and *E. remifer Smith and Radcliffe in Radcliffe 1913. 


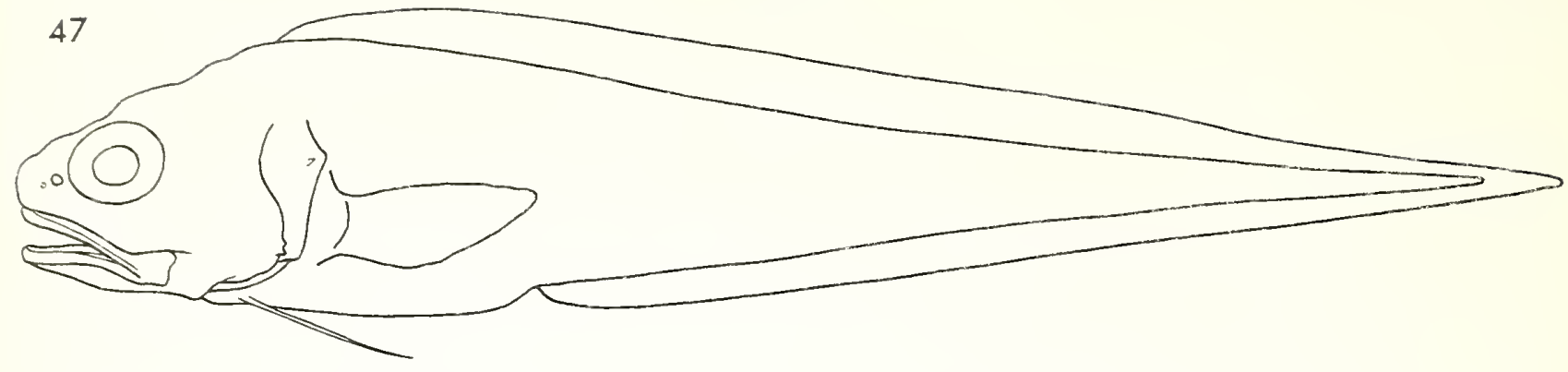

Ghptophidium Alcock (1889:390; type-species by monotypy Glyptophidium argenteum Alcock).

Head large, equal to or greater than one-half preanal distance. Eye diameter equal to or greater than length of snout. Opercular spine broad. flat, and weak (except in an unclescribed species in which it is narrow and pointed). Head bones thin with crests. Basibranchial with 1 or 2 median and 1 pair of tooth patches. Vomer with $\mathbf{V}$-shaped tooth patch. Developed rakers on anterior gill arch 15 to 35 . Pectoral fin rays 23 to 27 . Ventral fins with 1 or 2 rays in each. Precaudal vertebrae 11 to 13.

Bathyal depths from the western Indian Ocean to Hawaii.

Five valid described Recent species are listed below. In addition, $G$. litheus has been described from the Miocene of Japan (Sato 1962). Another Recent species is being described by J. G. Nielsen, who is studyinz the genus. The five species are: ${ }^{*} G$. argenteum Alcock 1889, ${ }^{*} G$. longipes Norman 1939, ${ }^{*} G$. lucidum Smith and Radcliffe in Radcliffe 1913. * $\mathrm{z}$. macropus Alcock 1894, and ${ }^{*} G$. oceanicum Smith and Radcliffe in Radcliffe 1913 (G. japoricum Kamohara 1936 is a svnonym).

\section{Holcomycteronus Garman}

(Fig. 48)

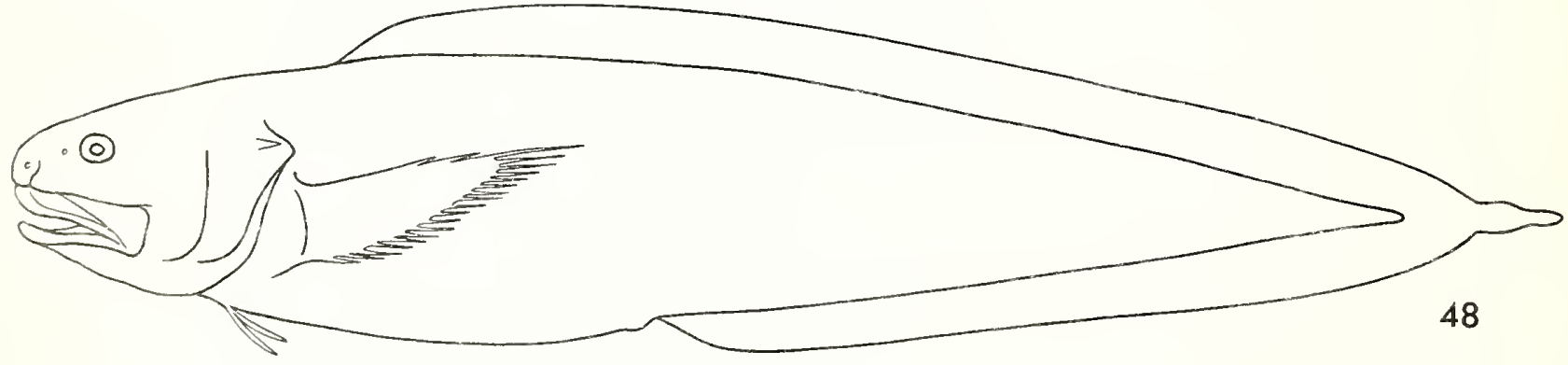

Holcomveternnus (Garman 1899:162; type-species by monotypy Holcomycteronus digittatus Garman).

Grimaldichthys (Roule 1913:2; type-species by monotypy Grimaldichthys profundissimus Roule).

Snout longer than eye. Opercular spine strong. Mucous cavities on head not prominent. Basibranchial with 2 median and 1 pair of tooth patches. Vomer with a V-shaped tooth patch. Developed rakers on first gill arch 7 to 10 . Pectoral fin rays 15 to 21 , the ventral ones more or less free. Ventral fins with 2 rays in each, flattened distally, somewhat thicker in males. Branchiostegal rays 8 . Precaudal vertebrae 18 to 21.

Possihly related to Bassogigas, also see Epetriodus.

Circumglobal at bathyal, abyssal, and hadal depths. Holcomycteronus brucei is known from a single specimen caught in the Weddell Sea (lat. $68^{\circ} \mathrm{S}$, long. $37^{\circ} \mathrm{W}$ ), an extraordinary locality for an ophidioid fish.

The genus is being revised by J. G. Nielsen. Six species are recognized: *H. aequatoris (Smith and Radcliffe in Radcliffe 1913), *H. brucei (Dollo 1906), *H. digittatus Garman 1899, *H. profundissimus (Roule 1913), *H. pterotus (Alcock 1890a), and *H. squamosus (Roule 1916) (Bassogigas (Holcomycteronus) koefoedi Nybelin 1954 is a synonym).

\section{Homostolus Smith and Radcliffe}

(Fig. 49)

Homostolus Smith and Radcliffe in Radcliffe (1913:146; type-species by original designation Homostolus acer Smith and Radcliffe). 


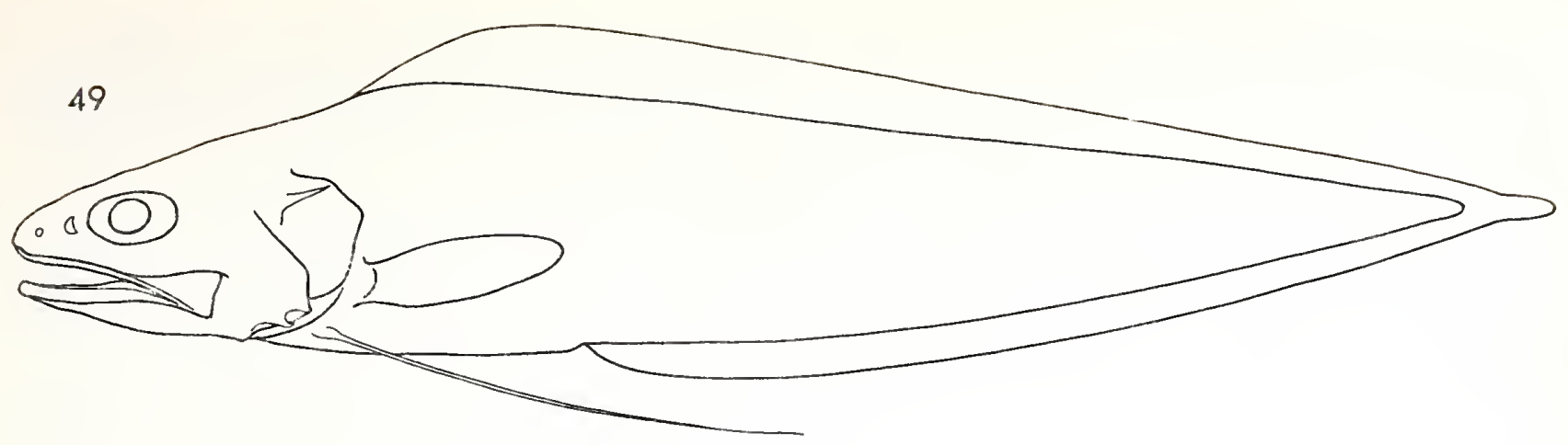

Lower jaw ending in a rather blunt point. Eye diameter equal to or larger than snout length. One or more short sharp spines at lower angle of preopercle. Jaw teeth granular, in narrow bands. Median basibranchial tooth patch one. Developed rakers on first gill arch 27 to 42. Pectoral fin placed low on the body, with 21 to 23 rays. Ventral fins with 1 ray in each, longer than head. Branchiostegal rays 8. Precaudal vertebrae 13.

Apparently related to Monomitopus and Selachophidium.

Taken off the Prilippines and Japan from depths of 380 to $1,000 \mathrm{~m}$.

Two species have been described: *H. acer Smith and Radcliffe in Radcliffe 1913, and H. japonicus Matsubara 1943.

\section{Hypopleuron Smith and Radeliffe}

(Fig. 50)

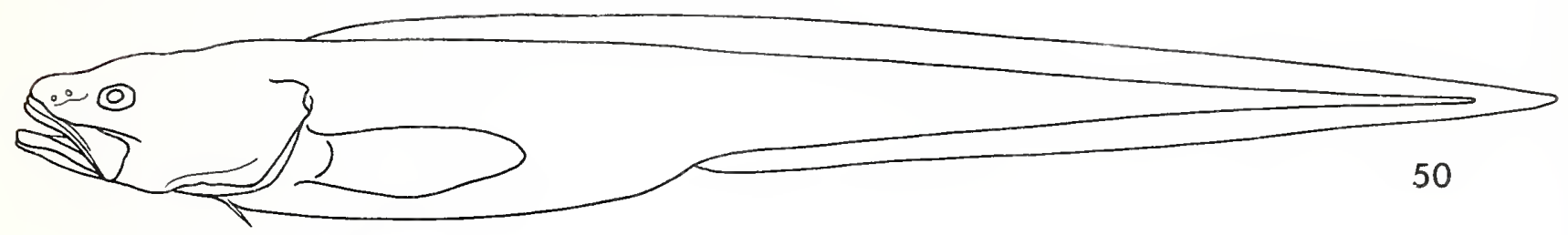

Hypopleuron Smith and Radcliffe in Radcliffe (1913:164; type-species by original designation Hypopleuron caninum Smith and Radcliffe).

Jaws equal in length or lower jaw slightly longer. Some teeth enlarged, a small canine at the front of each upper jaw. No spines on opercle and preopercle. Lateral line with small scales overlying an inner series of larger scales. Developed gill rakers 3. Median basibranchial tooth patch single. Ventral fins with 1 ray in each. Pectoral fin rays 26. Branchiostegal rays 8. Precaudal centra 22. Parapophyses of precaudal centra broad and inflated, enclosing the thick-walled swim bladder.

For possible relationships see Lamprogrammus.

Taken from Philippine waters and the Arabian Sea at depths ranging from 300 to $485 \mathrm{~m}$.

A single species, ${ }^{*} H$. caninum Smith and Radcliffe in Radcliffe 1913.

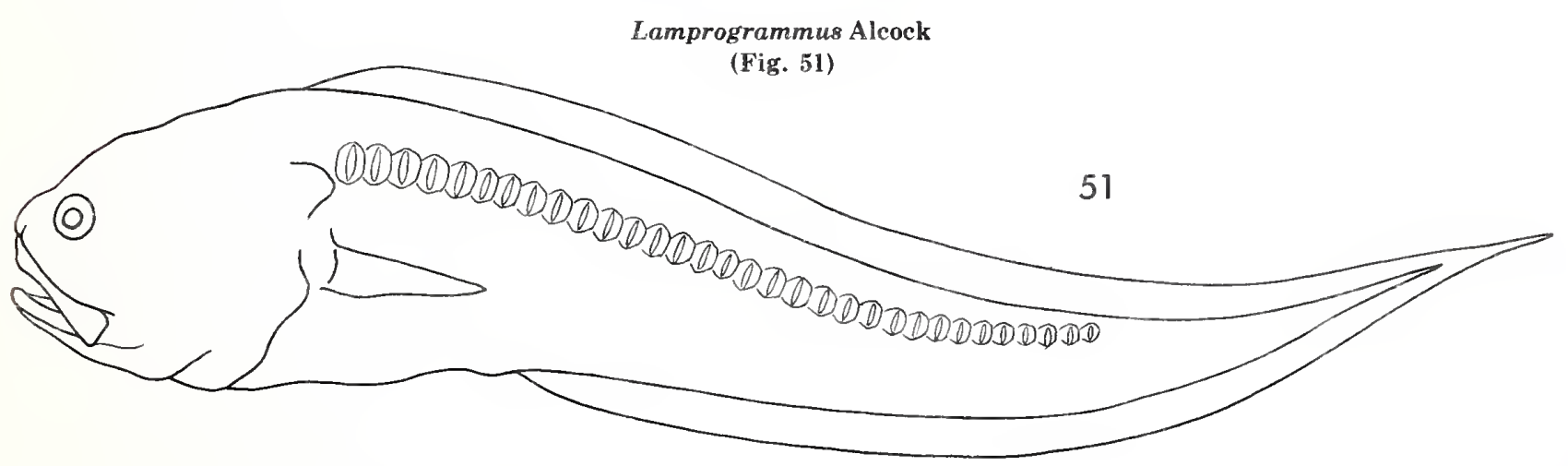

Lamprogrammus Alcock in Wood-Mason and Alcock (1891:32; type-species by monotypy Lamprogrammus niger Alcock). 
Ventral fins absent in adults, apparently present as stublike rudiments in juveniles of at least $L$. niger. Median basibranchial tooth patches absent in $L$. niger and L. illustris, 1 in other species. Branchiostegal rays 8 . Caudal fin rays 8 . Mouth terminal. Teeth granular. Precaudal vertebrae 12 to 14 . Opercular spine absent or flattened, weak, and flexible. Swim bladder small and thick-walled, supported by broad, strong parapophyses. Ribs on anterior several centra enlarged. Head cavernous, bones delicate, poorly ossified.

The lateral line of $L$. niger and probably most other species is highly distinctive and consists of a single series covered with small scales and placed high on the body, of vertically oriented, spindle-shaped neuromasts, each of which is mounted on a large, vertically elongate scale (see Garman 1899, pl. 34 for an illustration of this character in L. illustris). The lateral line system and its skin and scale cover are deciduous in some species and are often entirely or partly absent in preserved specimens. These structures have not been found on all described species, and the extent to which they constitute a common generic character is not known.

Similar lateral lines in Lamprogrammus and Hypopleuron have been noted by Smith and Radcliffe (in Radcliffe 1913). The latter also has enlarged parapophyses and anterior ribs. Eolamprogrammus from the Paleocene of Turkmenia has been suggested as a relative of Lamprogrammus (Danil'chenko 1968) on the basis of body shape and absence of pelvic fins. It also has enlarged anterior ribs but small parapophyses. Lamprogrammus has been grouped with Glyptophidium in several keys, chiefly on the basis of the frail crested head bones and thin skin in both. It seems unlikely, though. that the two genera are very closely related.

Circumtropical, probably meso- and bathypelagic, although large individuals are caught in bottom trawls as well as midwater nets.

It may be necessary to recognize two genera for the four species listed below and one or more undescribed ones: ${ }^{*} L$. exutus Nybelin and Poll 1958, ${ }^{*}$ L. fragilis Alcock 1892, ${ }^{*}$ L. illustris Garman 1899, and ${ }^{*}$ L. niger Alcock in Wood-Mason and Alcock 1891. (We transfer L. macropterus to Bassobythites.)

\section{Leucicorus Garman}

(Fig. 52)

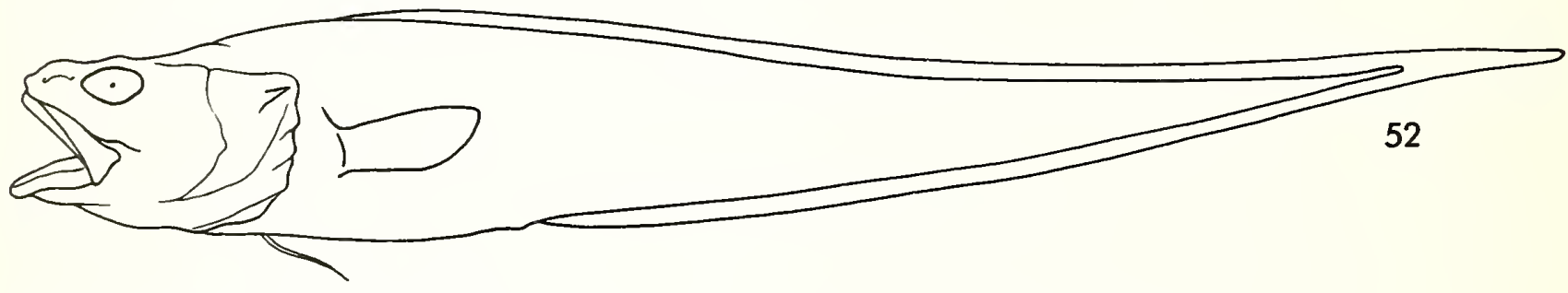

\section{Leucicorus Garman (1899:146; type-species by monotypy Leucicorus lusciosus Garman).}

Orbit large, but eye lens rudimentary or lacking. Head with prominent mucous cavities and distinctive rows of pores. Mouth terminal, with granular teeth. Anterior gill arch with 8 to 12 long rakers. Median basibranchial tooth patch single. Opercular spine weak. Branchiostegal rays 8 . Ventral fins with 2 rays in each. Caudal fin rays 8 . Precaudal vertebrae 13 or 14 . Swim bladder single-chambered and thin walled.

Apparently related to Bathyonus. Leucicorus has been revised by Nielsen (1975a).

Abyssal in the eastern Pacific and abyssal-hadal in the Caribbean.

Two species: ${ }^{*} L$. atlanticus Nielsen $1975 \mathrm{a}$, and ${ }^{*}$ L. lusciosus Garman 1899.

\section{Luciobrotula Smith and Radcliffe}

(Fig. 53)

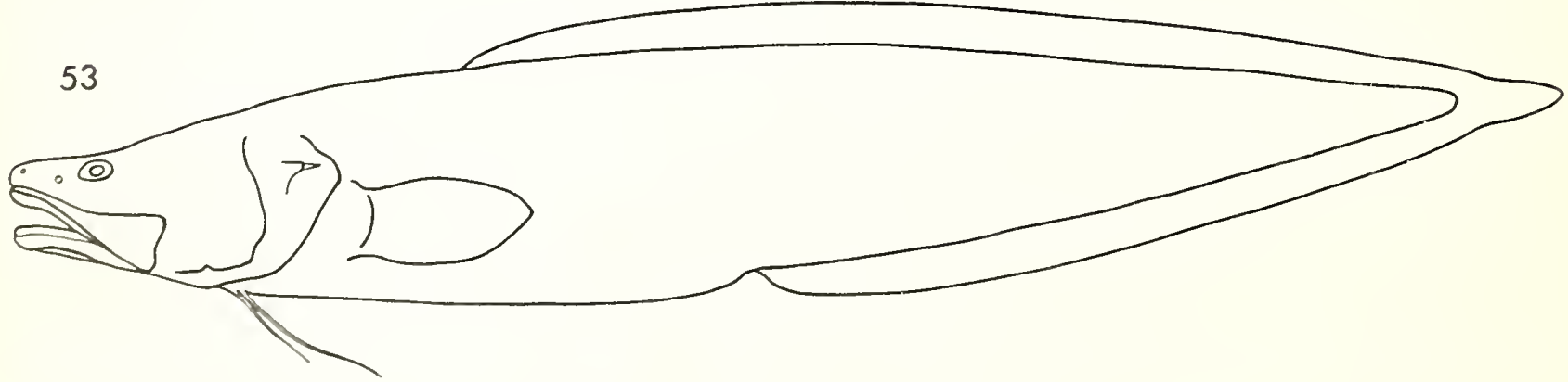


Luciobrotula Smith and Radcliffe in Radcliffe (1913:170; type-species by original designation Luciobrotula bartschi Smith and Radcliffe).

Volcanus Gosline (1954:78; type-species by original designation Volcanus lineatus Gosline).

Snout depressed, naked, bearing fleshy flaps and ridges at the tip. Head large, equal to about one-half preanal length. Rear margin of preopercle free, lacking spines. Opercle with a spine at the upper angle. Developed gill rakers 3 . Teeth granular. Median basibranchial tooth patch single. Branchiostegal rays 8 . Caudal fin rays 10 to 12 . Ventral fins with 2 rays in each. Pectoral fin rays 25 to 29 . Precaudal vertebrae 14 to 16.

For possible relationships see Spottobrotula.

Circumtropical at continental slope depths.

For additional information see Cohen (1964a, 1974b). Three described species and possibly two undescribed: ${ }^{*} L$. bartschi Smith and Radcliffe in Radcliffe $1913,{ }^{*}$ L. corethromycter Cohen 1964a, and ${ }^{*} L$. lineata (Gosline 1954).

Mastigopterus Smith and Radcliffe

(Fig. 54)

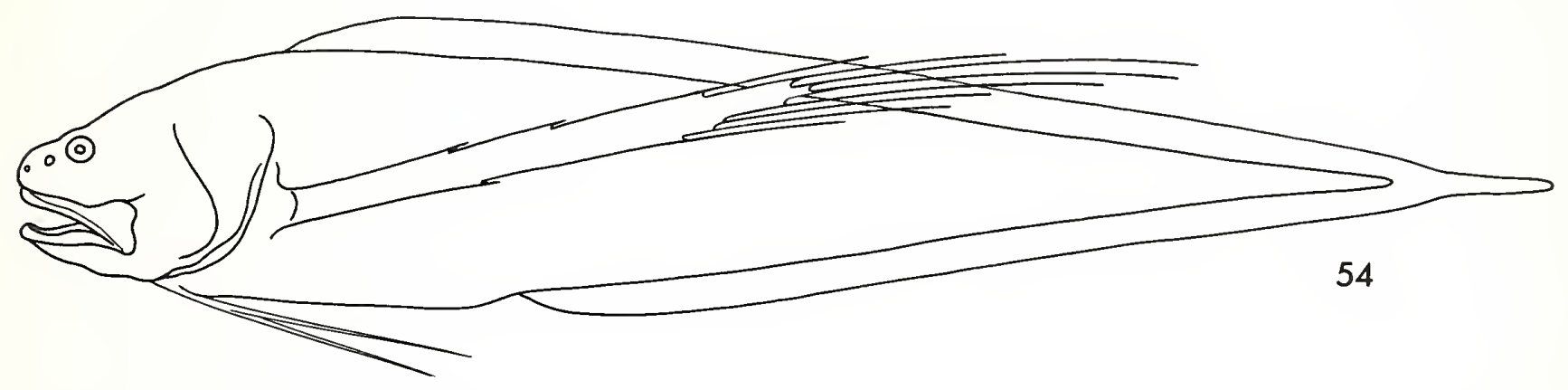

Mastigopterus Smith and Radcliffe in Radcliffe (1913:158; type-species by original designation Mastigopterus imperator Smith and Radcliffe).

Head large: mouth subterminal. Eye diameter less than snout length. Opercular spine broad and flattened, weak. Prominent mucous cavities and pores below eyes and on rear margin of preoperculum. Median basibranchial tooth patches 2. Vomer with V-shaped tooth patch. Anterior gill arch with 10 long rakers. Pectoral fin with 12 to 14 rays, the longest of which are about one-half or more of the standard length. Ventral fins with 2 joined rays in each. Caudal fin rays 6. Branchiostegal ravs 8 . Precaudal vertebrae 15 .

Possibly related to Dicrolene and Bathyonus.

Known from 3 specimens fished from the bottom between 1,500 and about 2,350 m off Madagascar and in Philippine waters.

Two described species: ${ }^{*} M$. imperator Smith and Radcliffe in Radcliffe 1913, and ${ }^{*} M$. praetor Smith and Radcliffe in Radcliffe 1913.

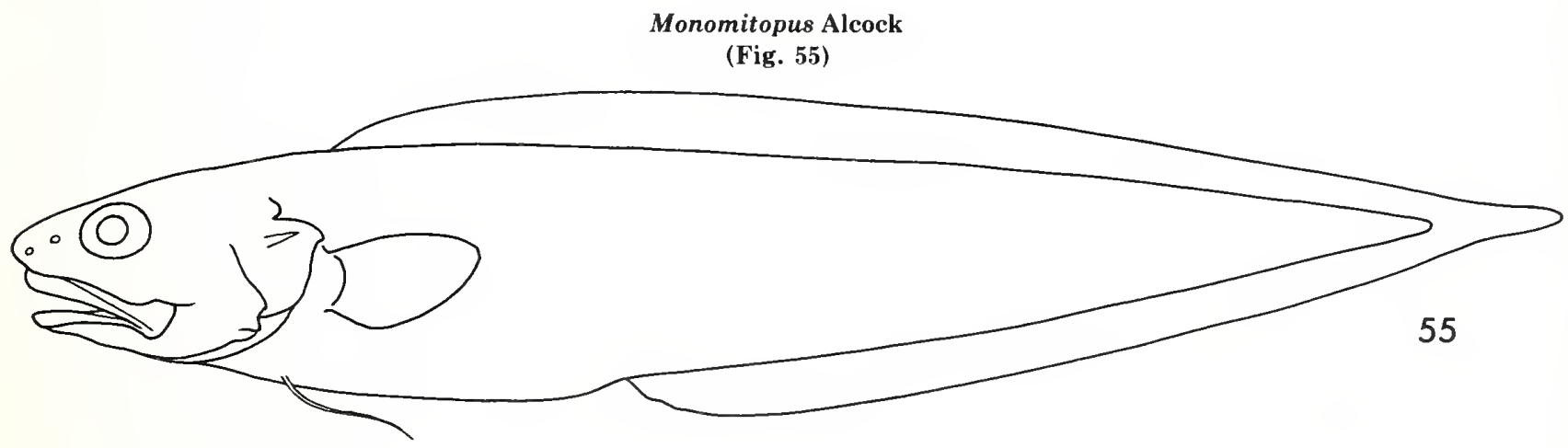

Monomitopus Alcock (1890b:297; type-species by monotypy Sirembo nigripinnis Alcock).

Dicromita Goode and Bean (1896:319; type-species by subsequent designation of Jordan and Evermann (1896), Dicromita agassizii Goode and Bean).

Monomeropus Garman (1899:158; type-species by original designation Monomeropus malispinosus Garman). 
Mouth terminal or subterminal. Eye diameter equal to or slightly shorter than snout length. Opercular spine strong. Preoperculum with 2 or 3 more or less distinct spines at the lower angle. Median basibranchial tooth patch single. Developed rakers on anterior gill arch 17 to 27 . Pectoral fin rays 26 to 33 . Ventral fins with 1 or ?2 rays in each. Precaudal vertebrae 12 to 14 .

Monomeropus is here considered a junior synonym of Monomitopus. The characters used for separating it from Monomitopus. degree of head armature, cavernous structure of the head, distinctness of lateral line, length of ventral

fins, etc.. are all variable within Monomitopus (sensu stricto).

Selachophidium and probably Homostolus appear to be derivatives of Monomitopus.

Found around the world beneath tropical and subtropical seas at depths ranging from about 200 to $1,870 \mathrm{~m}$.

We tentatively refer 13 described species to this genus, which is much in need of revision. An unnamed species from the Blake Plateau will be described by D. M. Cohen. The species are: ${ }^{*} M$. agassizii (Goode and Bean 1896), ${ }^{*} M$. americanum (Nielsen 1971), *M. conjugator (Alcock 1896), ${ }^{*} M$. garmani (Smith and Radcliffe in Radcliffe 1913), ${ }^{*} M$. kumae Jordan and Hubbs 1925, M. longiceps Smith and Radcliffe in Radcliffe 1913, *M. malispinosus (Garman 1899), * M. metriostoma (Vaillant 1888), *M. microlepis Smith and Radcliffe in Radcliffe 1913, * M. nigripinnis (Alcock 1889), ${ }^{*}$ M. pallidus Smith and Radcliffe in Radcliffe 1913, M. torvus Garman 1899, and ${ }^{*}$ M. vitiazi (Nielsen 1971).

Neobythites Goode and Bean

(Fig. 56)

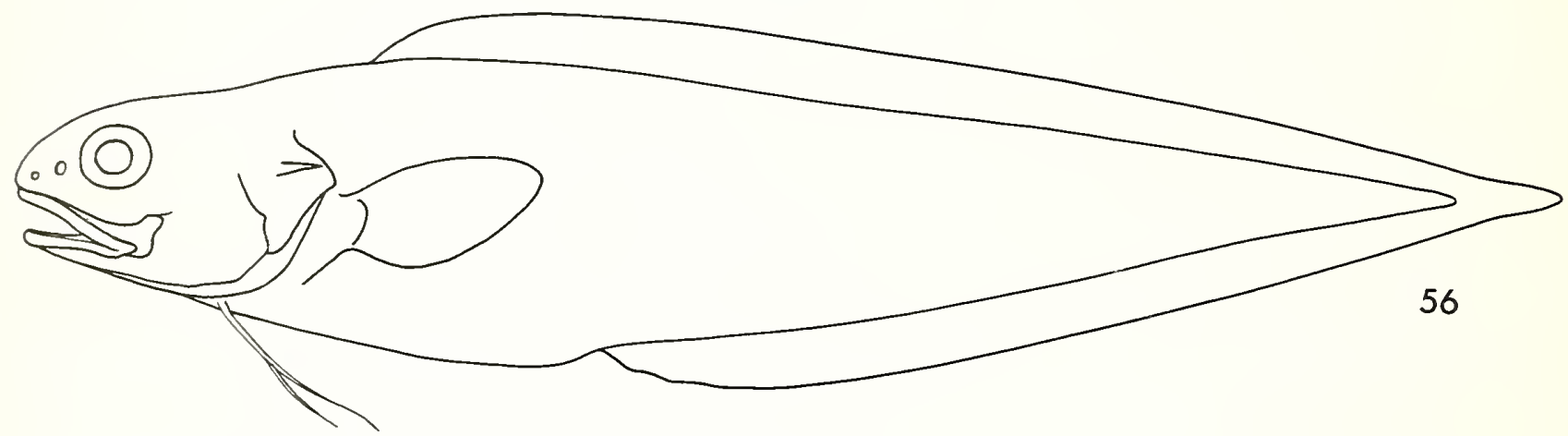

Neobythites Goode and Bean (1886:600; type-species by monotypy Neobythites gillii Goode and Bean).

Tetranematopus Günther? (1887:100; nomen nudum).

Watasea Jordan and Snyder (1901:765; type-species by original designation Watasea sivicola Jordan and Snyder).

Mouth terminal or subterminal. Body relatively short, tail not long and tapering. Eye diameter equal to or slightly shorter than snout length. Opercular spine strong. Median basibranchial tooth patches 2. Developed rakers on first gill arch 7 to 20. Pseudobranchial filaments 3 to 7 . Pectoral fin rays 22 to 28 . Ventral fins with 2 rays in each. Precaudal vertebrae 11 to 14 . Lateral line distinct. Most species with spots or bands on the sides and/or median fins.

Possibly related to Benthocometes among shallow-water genera and to Bassogigas among the deeper water forms.

Circumtropical at bathyal depths. Common.

Many species now referred to other genera were originally described in Neobythites. We tentatively recognize 14 species of Neobythites, but a much needed revision undoubtedly will show that some of these are conspecific: ${ }^{*} N$. analis. Barnard 1927, *N fasciatus Smith and Radcliffe in Radcliffe 1913, *N. gillii Goode and Bean 1886, * $N$. longipes Smith and Radcliffe in Radcliffe $1913,{ }^{*} N$. macrops Günther $1887,{ }^{*} N$. malayanus Weber $1913,{ }^{*} N$. marginatus Goode and Bean 1886, ${ }^{*} N$. nigromaculatus Kamohara $1938,{ }^{*} N$. ocellatus Günther $1887,{ }^{*} N$. purus Smith and Radcliffe in Radcliffe 1913, ${ }^{*} N$. sivicola (Jordan and Snyder 1901), ${ }^{*} N$. steatiticus Alcock $1893,{ }^{*} N$. stelliferoides Gilbert 1890, and ${ }^{*} N$. unimaculatus Smith and Radcliffe in Radcliffe 1913.

\section{Parabassogigas Nybelin}

(Fig. 57)

Parahassogigas Nybelin (1957:298; type-species by original designation Sirembo grandis Günther).

Head more than 2 times in preanal length in adults, less in juveniles. Snout longer than eye. Opercular spine strong. Median basibranchial tooth patches 2. Vomer with a diamond-shaped tooth patch. Developed rakers on first arch 7 or 8 . Pectroral fin rays 21 to 27 ; fin short, not reaching vent. Ventral fins with 2 rays in each. Branchiostegal rays 8 . Precaudal vertebrae 19 to 24 . Lateral line short. 


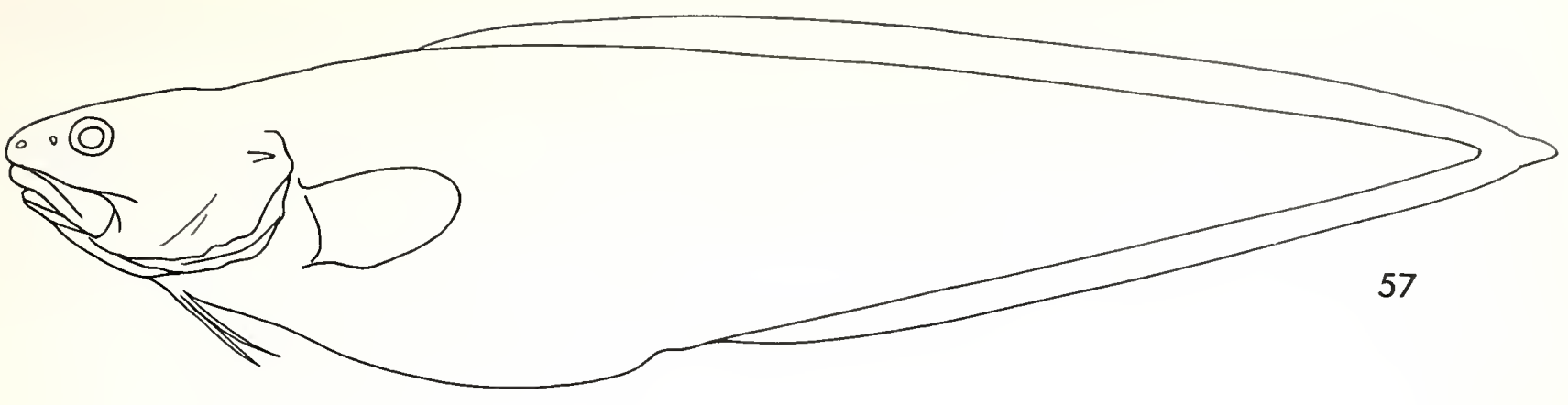

Probably related to Barathrites and Barathrodemus.

For comments on the possible larval form see the following nominal genus, Spectrunculus.

Abyssal and bathyal in the Pacific and Atlantic.

Three nominal species are assigned to this genus, which is being revised by J. G. Nielsen: ${ }^{*} P$. coheni (Mayer and Nalbant 1972 ), ${ }^{*} P$. crassus (Vaillant 1888 ), and ${ }^{*} P$. grandis (Günther 1877 ).

\section{Penopus Goode and Bean}

(Fig. 58)

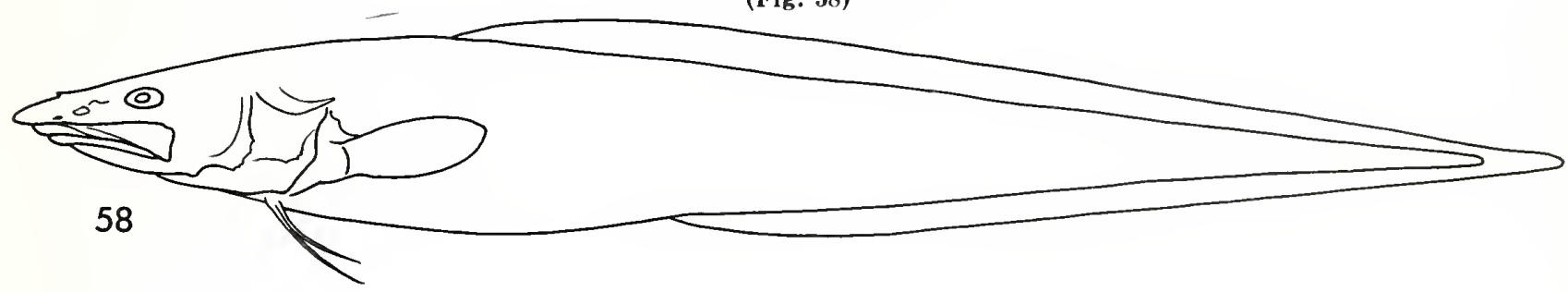

Penopus Goode and Bean (1896:335; type-species by monotypy Penopus macdonaldi Goode and Bean).

Head depressed anteriorly. Snout long; projecting over mouth. Body long and slender, depth at vent about 11 times in standard length. Eyes minute. Preoperculum with 4 or 5 spines at the lower angle. Operculum with a strong, curved spine dorsally and 2 or 3 weak, flattened projections at the lower angle. Median basibranchial tooth patches 2, the posterior one small. Lateral line represented by 3 rows of circular organs. Developed rakers on first arch 8 to 10 . Pectoral fin with 18 or 19 rays. Ventral fins with 2 rays in each, bound together for the length of rays. Branchiostegal rays 8 . Precaudal vertebrae 18 or 19 .

Related to Porogadus.

Tropical Atlantic Ocean at bathyal and abyssal depths.

Two nominal species, of which only one may be valid: ${ }^{*} P$. macdonaldi Goode and Bean 1896, and *P. microphthalmus (Vaillant 1888).

Petrotyx Heller and Snodgrass

(Fig. 59)

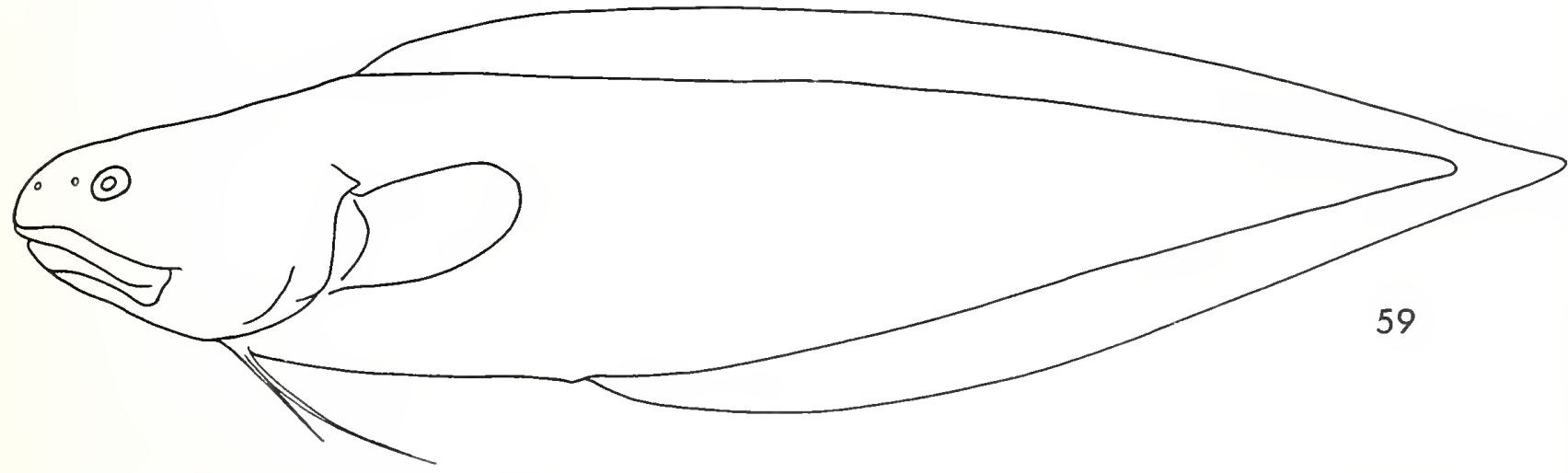

Petrotyx Heller and Snodgrass (1903:222; type-species by monotypy Petrotyx hopkinsi Heller and Snodgrass). 
Pseudobvthites Meek and Hildebrand (1928:968; type-species by original designation Pseudobythites sanguineus Meek and Hildebrand).

Snout naked. densely covered with small, fleshy papillae. Rear margin of preopercle overgrown with skin. No spines on preopercle or opercle. Upper margin of maxillary sheathed. Developed gill rakers 3. Median basibranchial tooth patch single: paired patches 1 . Branchiostegal rays 8 . Pectoral fin rays 24 to 27. Caudal fin rays 10. Ventral fins with 2 rays in each. Precaudal vertebrae 12 .

Shallow-water, reef-dwelling fishes of tropical American seas.

The genus has been reviewed by Böhlke (1955), who recognized two species: ${ }^{*} P$. hopkinsi Heller and Snodgrass 1903, and ${ }^{*} P$. sanguineus (Meek and Hildebrand 1928).

Porogadus Goode and Bean

(Fig. 60)

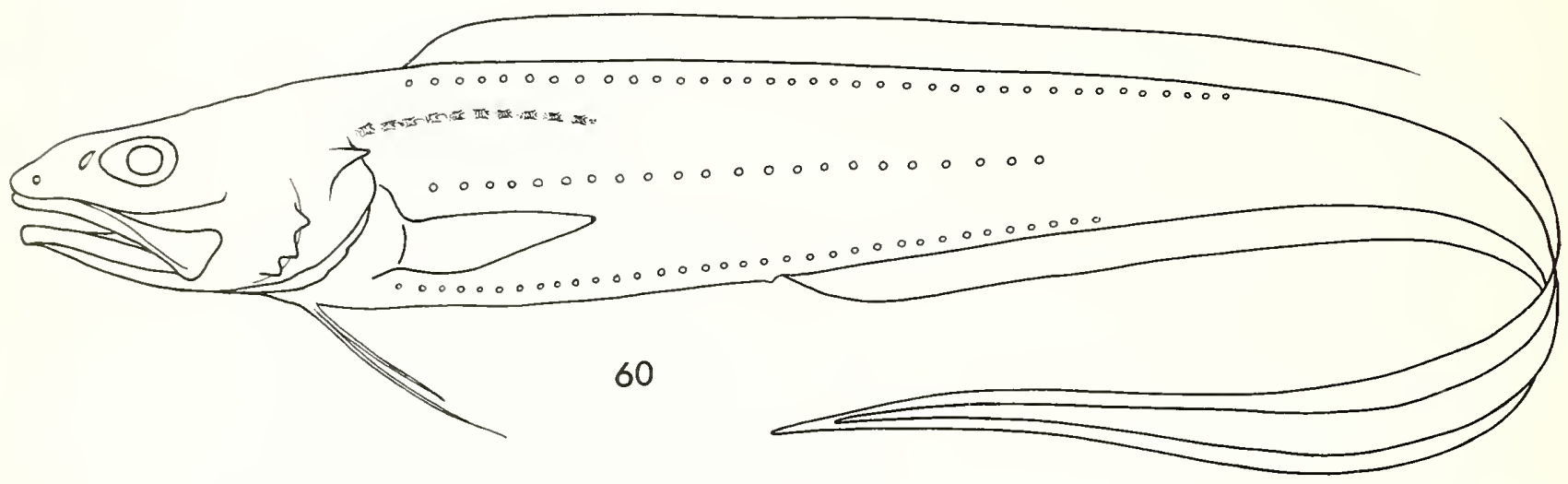

Porogadus Goode and Bean (1886:602; type-species by monotypy Porogadus miles Goode and Bean).

Dermatorus Alcock (1890b:298; type-species by monotypy Dermatorus trichiurus Alcock).

Celema Goode and Bean (1896:329; type-species by subsequent designation of Jordan 1920, Porogadus nudus Vaillant).

Moebia Goode and Bean (1896:331; type-species by original designation Bathynectes gracilis Günther 1878).

Body long and slender, depth at vent 10 times or more in standard length. Head length equal to approximately onehalf preanal length. Prominent mucous cavities beneath orbital region and on posterior margin of preopercle. Lateral line represented by 3 rows of circular organs, large and prominent in some species, less so in others (sometimes missing from trawled specimens), and by a row of modified scales, deciduous in most specimens. Spines on top and sides of head variously developed in different species. Median basibranchial tooth patch single. Vomer with a V-shaped tooth patch. Developed rakers on first gill arch 13 to 20. Caudal fin rays 6 . Pectoral fin rays 17 to 20 . Ventral fin with ?1 or 2 rays in each. Branchiostegal rays 8. Precaudal vertebrae 16 to 18 .

Porogadus is apparently related to Bathyonus, differing chiefly in having a longer tail, larger eyes, and normal pectoral fins. It is similar to Penopus in its lateral line and may be related also to Alcockia.

Circumglobal beneath tropical and temperate seas at bathyal and abyssal depths.

Fourteen described species may be referred to Porogadus, which is much in need of revision. Species groups have been discussed by Nybelin (1957). The species are: ${ }^{*} P$. abyssalis Nybelin 1957, P. atripectus Garman 1899, P. breviceps Garman 1899, *P. catena (Goode and Bean 1886), *P. gracilis (Günther 1878), P. guentheri Jordan and Fowler 1902, $P$. longiceps Garman 1899, * P. melampeplus (Alcock 1896), * P. melanocephalus (Wood-Mason and Alcock 1891), * P. miles Goode and Bean 1886, *P. nudus Vaillant 1888, *P. promelas Gilbert 1891, *P. subarmatus Vaillant 1888, *P. trichiurus (Alcock 1890h).

\section{Pycnocraspedum Alcock}

(Fig. 61)

Pycnocraspedum Alcock (1889:386; type-species by monotypy Pycnocraspedum squamipinne Alcock).

Itatius Matsubara (1943:40; type-species by original designation Itatius microlepis Matsubara).

Rear margin of preopercle free, lower angle with 3 spines. A single strong spine on opercle. Eye relatively large, equal to or slightly smaller than snout. Head large, longer than one-half preanal length. Developed gill rakers 4 . Teeth granular. Median basibranchial tooth patches 2. Branchiostegal rays 8. Pectoral fin rays 24 to 28. Caudal fin rays 10. Ventral fins with 2 rays in each. Precaudal vertebrae 12. 


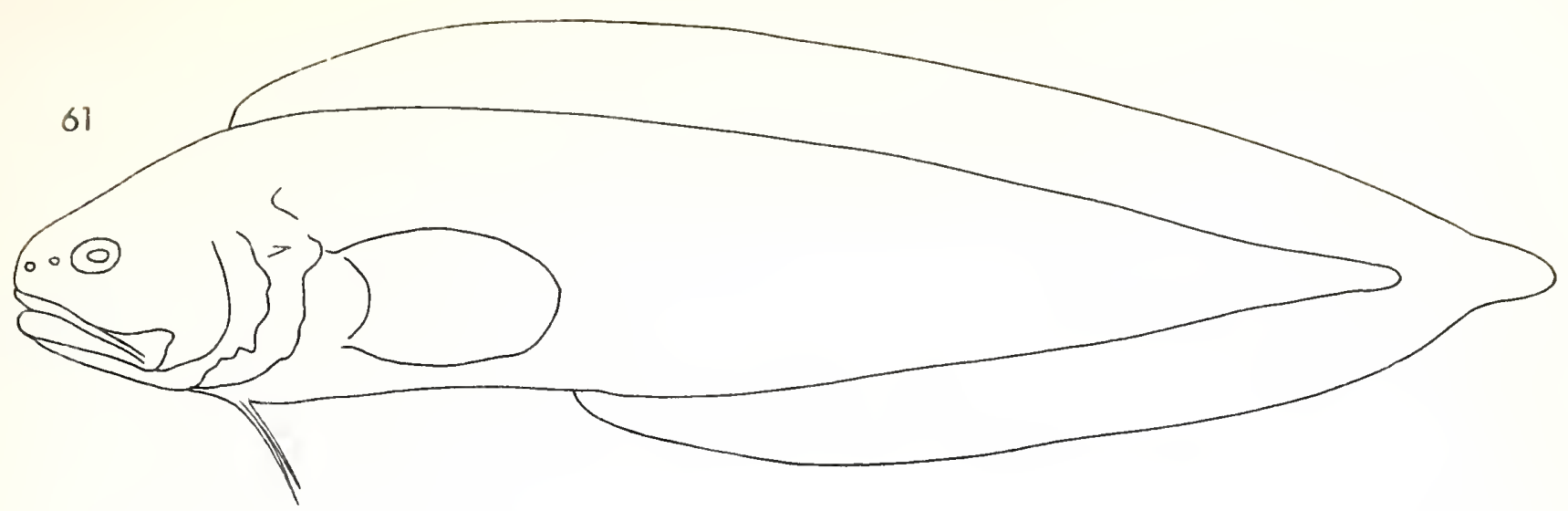

For possible relationships see Spottobrotula.

Juvenile a deep-bodied pelagic form; adults benthic at moderate depths.

Tropical western Atlantic, Indian Ocean, Japan, and Hawaii.

The genus is being studied by D. M. Cohen. There are four nominal species, of which possibly only one or two are valid: *P. armatum Gosline 1954, ${ }^{*} P$. microlepis (Matsubara 1943), ${ }^{*}$. phyllosoma (Parr 1933), and * $P$. squamipinne Alcock 1889.

Selachophidium Gilchrist

(Fig. 62)

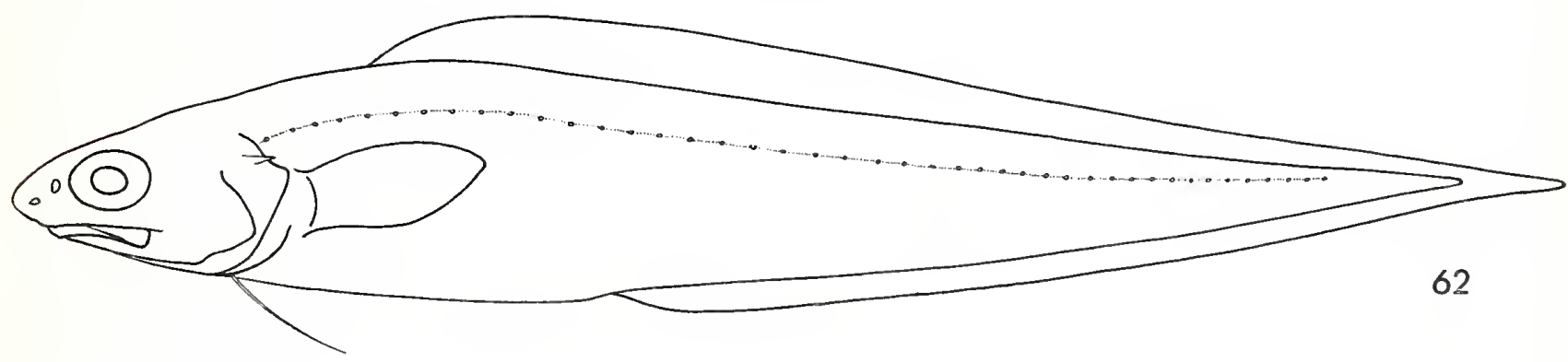

Selachophidium Gilchrist (1903:209; type-species by monotypy Selachophidium guentheri Gilchrist).

Snout inflated; mouth inferior. Eye large, diameter greater than length of snout. Opercular spine distinct, although not very strong. Median basibranchial tooth patches 2. Vomer with a rather triangular tooth patch. Developed rakers on first arch 15 to 21. Pseudobranchial filaments 3 to 6 . Pectoral fin rays 26 to 29 . Ventral fins with 1 ray in each. Branchiostegal ravs 8 or 9 . Precaudal vertebrae 17 or 18 . Lateral line distinct.

Related to Monomitopus.

Taken at bathyal depths off South Africa.

A single species, ${ }^{*}$ S. guentheri Gilchrist 1903. Nielsen (1971) described two new species in this genus, which we transfer to Monomitopus.

\section{Spectrunculus Jordan and Thompson}

(Fig. 63)

Spectrunculus Jordan and Thompson (1914:301; type-species by monotypy Spectrunculus radcliffei Jordan and Thompson).

Head short, 2 to 3 times in preanal length. Mouth almost vertical. Eye diameter much less than snout length. Opercular spine strong. Teeth developed on dentaries, few elsewhere. Developed rakers on first gill arch 7 to 9. Pectoral fin rays 27 to 29 . Ventral fins with 2 thick rays in each. Branchiostegal rays 8. Precaudal vertebrae 21 to 23 . Vertebral centra rectangular in lateral view.

Epipelagic in the Pacific and Atlantic.

The four known specimens range from 52 to $59 \mathrm{~mm}$ in standard length. Gonads are not recognizable in any. Teeth are poorly developed. Vertebral centra appear typically larval in shape. These and other features lend substance to Norman's (1939:91) remark, "This genus is perhaps based upon a post-larval fish." Meristic characters and distribution 


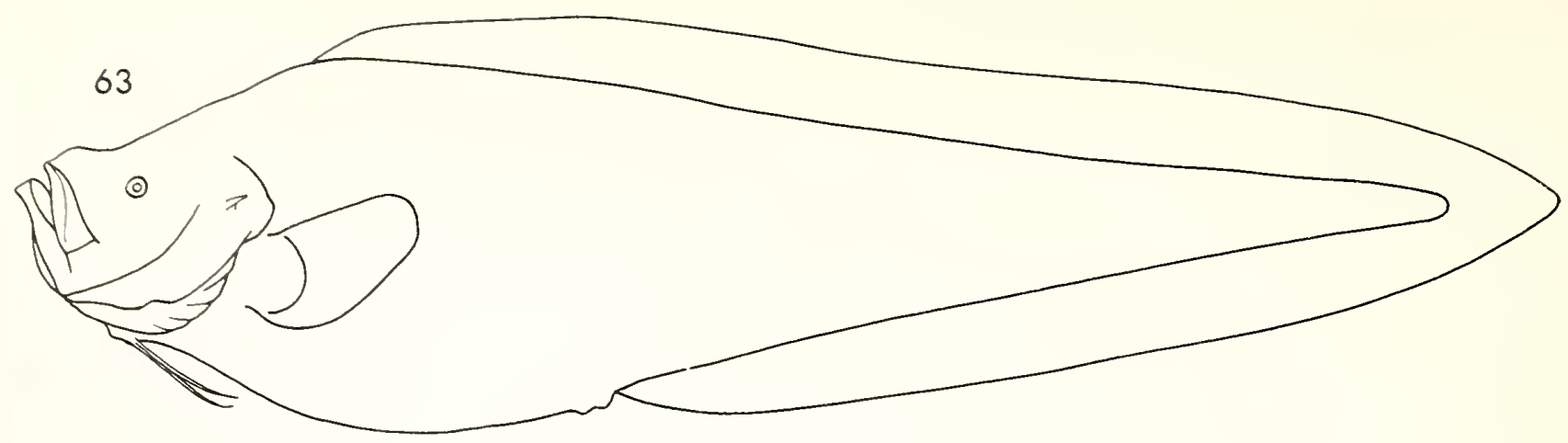

agree well with Parabassogigas. The proper identity of Spectrunculus is being studied by J. G. Nielsen and will be further discussed and documented in a separate paper.

A single nominal species, ${ }^{*} S$. radcliffei Jordan and Thompson 1914.

\section{Spottobrotula New Genus}

Trpe species Spottobrotula mahodadi new species.

Body relatively short, depth at vent about 5 times in standard length; preanal length about 2.3 times in standard length. Head compressed, about 2 times in preanal length and 4.4 times in standard length. Body completely covered with small. cycloid scales in regular rows. Head with similar scales, but anterior parts of snout and throat naked.

Exye diameter ahout equal to snout length, 4.6 times in head length. Anterior nostril with a thick, raised, rim about midway between tip of snout and anterior margin of eye; posterior nostril a simple pore immediately before eye. Opercle hearing a strong, pointed spine, which does not reach the rear margin of the head. Preopercle lacking spines. Branchiostegal ravs 8. Developed rakers on first gill arch 10. Pseudobranch well-developed, nearly as long as upper arm of first arch, hearing 25 to 30 filaments. Maxillary extending slightly beyond the rear margin of the eye (when mouth is closed), dorsal margin sheathed by subocular bones for most of its length, but free at the rear. Lower lips covered with tiny, densely distributed papillae. Teeth small and granular, in broad bands on the premaxillary, dentary, palatine, and vomer: a single, elongate, basibranchial tooth patch; no paired basibranchial tooth patches.

Lateralis system on head with very small pores, canals deeply buried. Lateral line on body a narrow naked tube extending along the side to nearly the end of the tail. About 50, short, ventrally directed branches, each with a tiny flap at its end. originating along the lateral line.

Pectoral rays 30 , the fin rounded and ending considerably short of vent, scale-covered proximally, a prominent flap of skin ahove its base. Ventral fins with 2 rays in each, inserted behind the symphysis of the cleithra by a distance about equal to the vertical diameter of the eye; rays bound together for the length of the fin by tough white skin and bearing many small papillae on the rather flattened distal half. Median fins covered with thick skin, scale-covered basally. Caudal fin rays 10.

Precaudal vertebrae 15. Neural spine on first centrum slightly shorter than those following; neural spines on precaudal centra rather blunt. Precaudal centra square in side view; caudal centra progressively more elongate. Ribs originating directly on centra 1 to 7 and on parapophyses from centra 8 to 15 . Ribs on first three centra appear to be expanded and longer than those following. Epipleural ribs present.

Color of head and body light brown; dark spots on dorsal part of body and dorsal fin. Ventral fin pale. Other fins darker than body.

Spottobrotula does not appear very similar to any known ophidiid genus; however, its closest affinities may lie with Petrotyx, Luciobrotula, and Pycnocraspedum, a cluster of apparently related genera discussed by Cohen (1964a). It most resembles the first two in having a single, median basibranchial tooth patch and resembles all three in the form of its lateral line and in having at least 10 caudal fin rays. It differs from all in its higher number of developed gill rakers, its fleshy ventral fin rays, bound together for the entire length of the fin, its large pseudobranch, and its spotted color pattern. It may be further distinguished from Petrotyx, which has no opercular spine; from Luciobrotula, which has a more elongate head and hody; and from Pycnocraspedum, which has 2 median basibranchial tooth patches and a spiny preopercle. Spottobrotula appears at least superficially similar to Brotula in several respects, particularly its compressed head, general hody shape, and fin configuration, and in having a large pseudobranch. Also, juveniles of some species of Brotula have spots. Notable differences between the two genera are the presence in Brotula of barbels and the absence of a median hasibranchial tooth patch. Also, Brotula has quite a different kind of lateral line, a series of small organs along the side of the body, which are connected by an imbedded, scale-covered canal.

Andaman Sea.

The name is taken from the Middle English word spotte, in reference to the color pattern.

A single species, described below. 


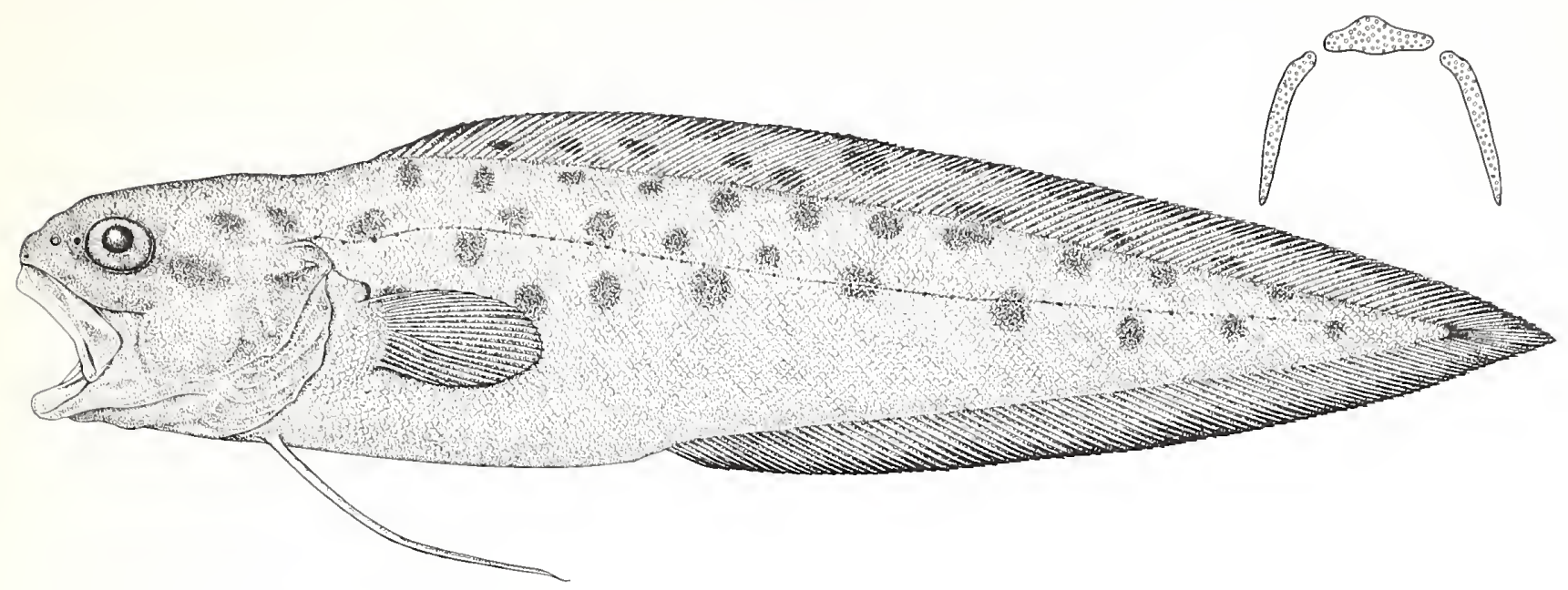

Figure 64.-Spottobrotula mahodadi; holotype, Kasetsart University 02842 . Upper right, tooth bearing surfaces of vomer and palatines. Drawn by Keikn Hiratsuka Moore.

Dorsal fin rays 101, not including a single, rayless, predorsal pterygiophore; anal fin rays 77; pectoral fin rays 30 , including a small dorsal and a small ventral splint; developed gill rakers on first arch $3+1+6$, rakers strong with a spiny inner margin. the longest raker equal to about one-half the horizontal diameter of the eye; longest gill filaments on first arch about equal in length to longest rakers. Vertebrae $15+39=54$. Lateral scale rows about 165.

Lateralis system on head marked by small pores, difficult to see; canals deeply buried. Supraorbital pores at least 2 , suborbital at least 6 , lateral at least 2, supratemporal at least 2, mandibular 5 , preopercular an undetermined number.

The following measurements are in millimeters, followed by percent of standard length in parentheses. Standard length 216, predorsal 52.0 (24.1), preanal 94.4 (43.7), preventral 37.9 (17.5), depth at vent 42.8 (19.8), head length 49.5 (22.9), horizontal diameter eye $10.8(5.0)$, least pigmented interorbital width $13.1(6.1)$, snout 10.4 (4.8), jaw length 23.8 (11.0), maxillary width 8.8 (4.1), pectoral length 29.1 (13.5), pectoral peduncle width $9.4(4.3)$, and ventral fin length $48.8(22.6)$.

The lining of the peritoneal cavity is dusky; the stomach and intestines are pale. Pyloric caecae numerous, about 85 . The liver is elongate, extending beyond the level of the posterior curve of the stomach on the left side of the body only. The swim bladder has a notably thick, tough wall, and an oval-shaped opening posteriorly. The unripe gonads are a pair of short, bean-shaped structures, joined together in the midline.

Holotype and only known specimen, Kasetsart University, Bangkok, College of Fisheries no. 02842. Andaman Sea, Andaman Islands, near Baren Island. Taken with hook and line at a depth of about $40 \mathrm{~m}$. ? 14-15 April 1970.

The name mahodadi is an ancient Indian name for the Bay of Bengal.

Typhlonus Günther

(Fig. 65)

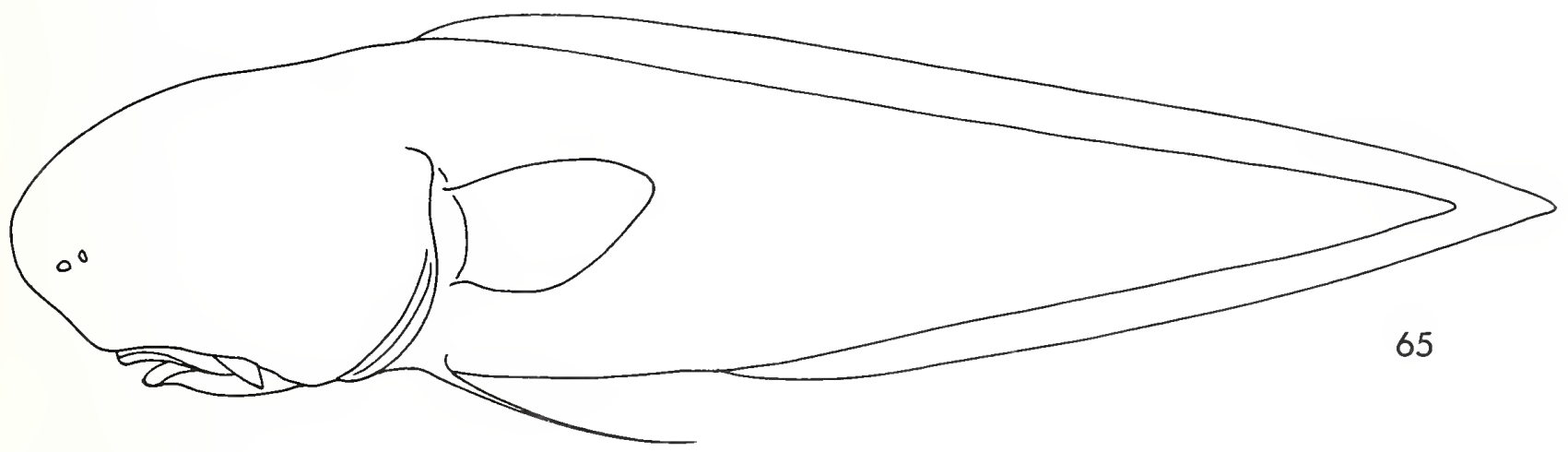

Typhlonus Günther (1878:21; type-species by monotypy Typhlonus nasus Günther). 
Head massively inflated. Head and body soft. Mouth inferior, with protrusible jaws. Teeth granular. Developed rakers (n) first gill arch 10 to 13. Median basibranchial tooth patch single or absent. Eyes small or not at all visible at surface of head. Opercular spine absent. Branchiostegal rays 7 or 8 . Ventral fins with 1 ray each. Pectoral fin rays 24 to 28 . Caudal fin ravs $\$$. Precaudal vertebrae 13 or 14 . Swim bladder single-chambered and thin-walled.

Abrsal depths in the Indo-Australian area and the tropical Atlantic.

The single described species, ${ }^{*} T$. nasus Günther 1878, has been redescribed by Nielsen (1965). A second species, from the Atlantic, is being described by J. Staiger, J. C. Hureau, and J. G. Nielsen.

\section{SUBORDER BYTHITOIDEI}

We include in this suborder (which is defined in the Key to Suborders) the following viviparous fishes.

In the subfamily Bythitinae of Bythitidae are placed those genera with confluent vertical fins, which formerly were referred to Brotulidae. Many were considered to be close relatives of genera that we include in the ophidiid subfamily Neobrthitinae.

The subfamily Brosmophycinae of Bythitidae contains genera with a free caudal fin. These also were placed in Brotulidae.

The aphyonid genera, here treated as a distinct family, are characterized chiefly, but not entirely, by many neotenic characters. Aphyonids have been considered by most authors as members of Brotulidae.

Various aspects of the reproductive biology of a number of species of bythitoid fishes have been discussed by Nielsen et al. (1968).

\section{Key to Families of Bythitoidei}

la. Most species with scales. Precaudal vertebrae 9-22. Swim bladder present . . . . . . . . Bythitidae

1h. Scales ahsent. Precaudal vertebrae 26-48. Swim bladder absent . . . . . . . . . Aphyonidae

\section{Bythitidae Gill 1861a}

Precaudal vert ebrae 9 to 22 . Swim bladder present. Anterior neural spine shorter than those following. Scales present in all but a few species. Developed rakers on first gill arch 6 or fewer.

\section{KEY TO FAMILIES OF BYTHITIDAE}

1a. Caudal fin joined to dorsal and anal fins $\ldots \ldots \ldots \ldots \ldots \ldots$ Bythitinae

1h. Caudal fin free from dorsal and anal fins $\ldots \ldots \ldots \ldots$ Brosmophycinae

\section{BYTHITINAE GILL 1861a}

Caudal fin joined to dorsal and anal fins, although strongly exserted in some species. Male intromittent organ with no ossified parts. Squamation on head and body variable, a few species completely naked. Ventral fins absent or with a single rav in each (except 2 in Thalassobathia and the fossil Propteridium), closely adjacent (except in Thalassobathia, see helow).

An account is presented of the fossil genus Propteridium, although it is not included in the following key.

A diverse group found from freshwaters to abyssal depths. Most species live at moderate depths.

Key to Genera of Bythitinae

1a. Ventral fins with 2, short, fleshy rays in each (Fig. 66) $\ldots \ldots \ldots \ldots$ Thalassobathia

1h. Ventral fins absent or with a single filamentous ray in each $\ldots \ldots \ldots \ldots$

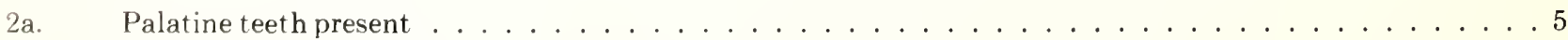

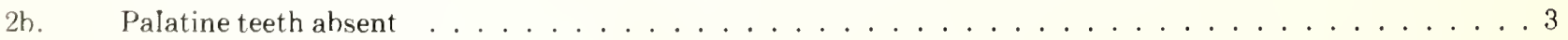




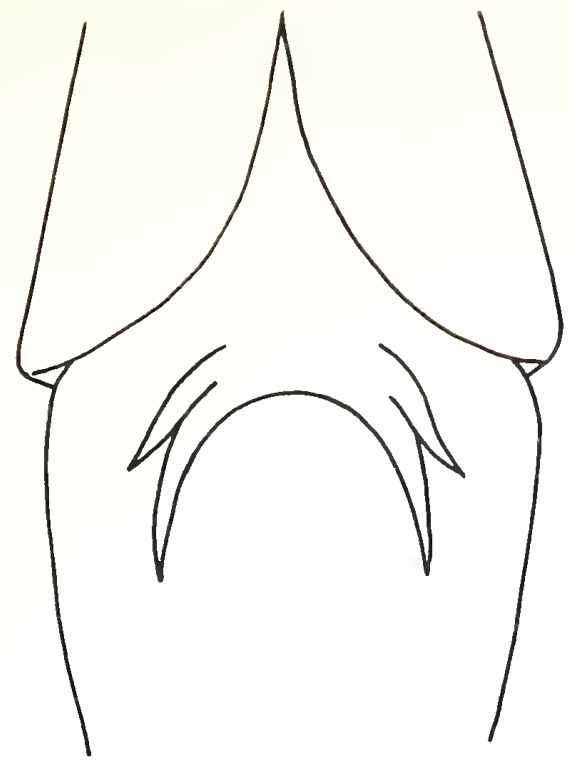

Figure 6fi.-Short, fleshy ventral fins of Thalassobathia.

3a. Rear of maxillary rounded, not expanded (Fig. 67a)

Stygnobrotula

3b. Rear of maxillary expanded (Fig. 67b)

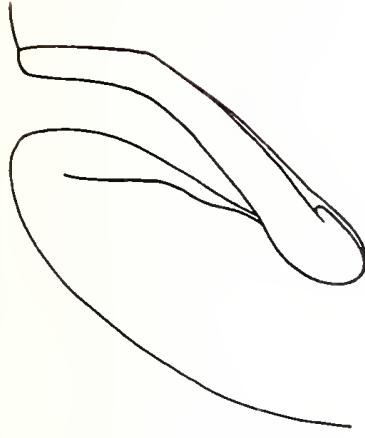

A

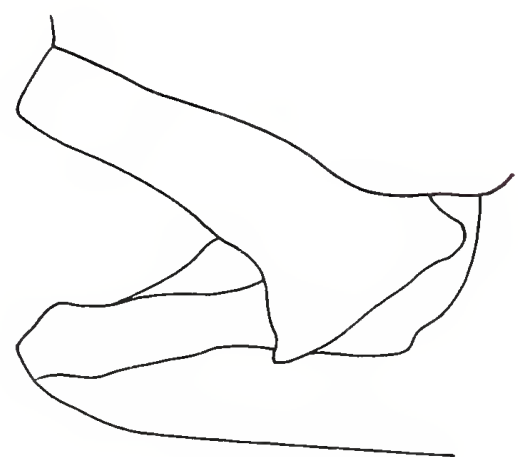

B
Figure 67.-Maxillary bone in two bythitine genera. A. Stygnobrotula, note the slender, rounded posterior end; B. Oligopus, note the expanded, truncate posterior end.

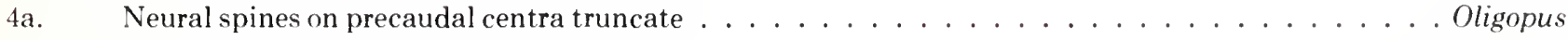

4h. Neural spines on precaudal centra pointed ......................Grammonoides

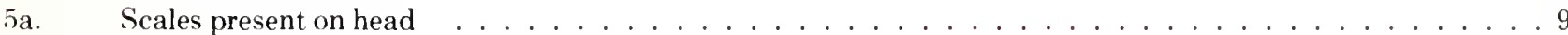

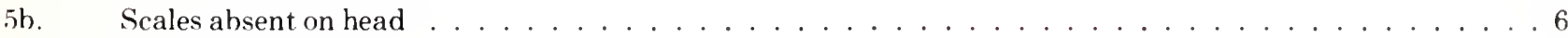

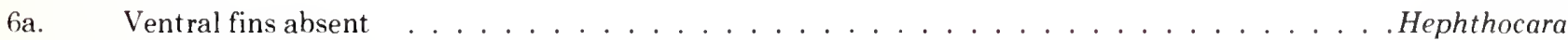

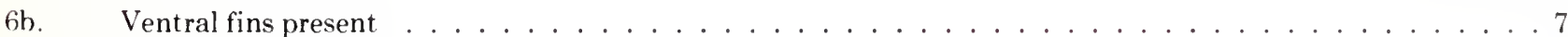

7a. Squamation on body absent or incomplete. Pectoral radials elongate ............ Saccogaster

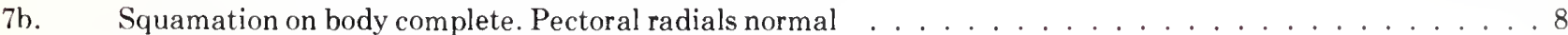


S. J Jaw teeth close-set and granular. A prominent skin flap with a pore at its end above opercle (Fig. 6s)

Diplacanthopoma

Sh. Jaw teeth somewhat separate from each other and needlelike. No prominent skin flap above inercle

Bythites

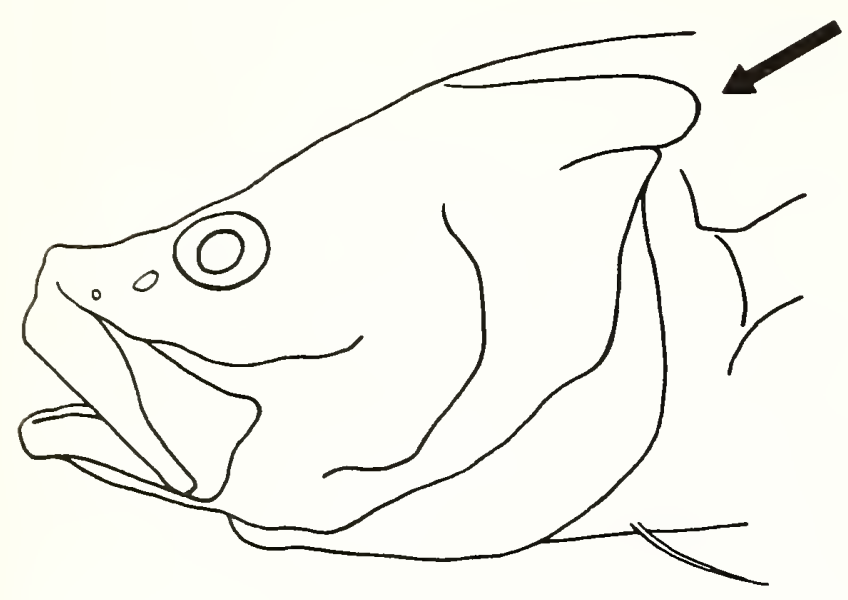

Figure 6ix.-Prominent skin flap on the head of Diplacanthopoma.

Pectoral fin on an elongate peduncle

Calamopteryx

(4). Pectoral fin periuncle not elongate

11: C.ircumorbital head pores large, a prominent median interorbital pore (Fig. 69) . . . . . . . Pseudonus

116). Circumorbital head pores variously developed. No prominent median interorbital pore ...........11

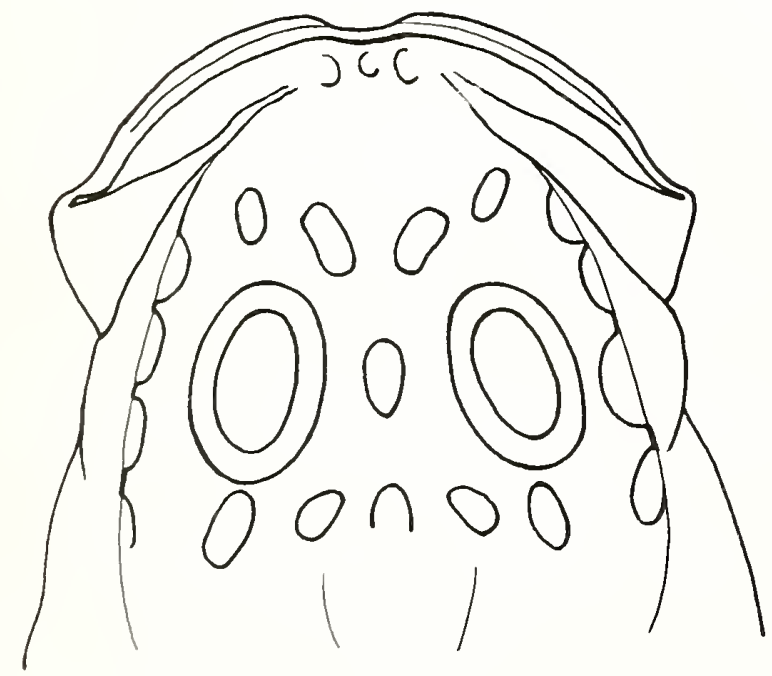

Figure ti9.--large pores on the head of Pseudonus.

1 la Ventral fins absent. Preopercle with several sharp-pointed spines at lower angle . . . . . . . Bellottia

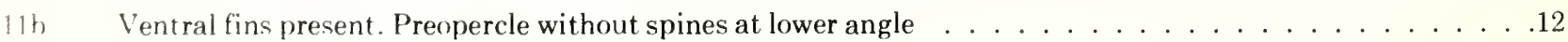

12. Vomerine teeth in a triangular patch or a V-shaped or U-shaped band. Branchiostegal rays 8 . . . . . . .13

12h. Vomerine teeth completely or nearly divided into two separate patches. Branchiostegal rays 7 . . Microbrotula 


\section{A bythites Nielsen and Cohen}

(Fig. 70)

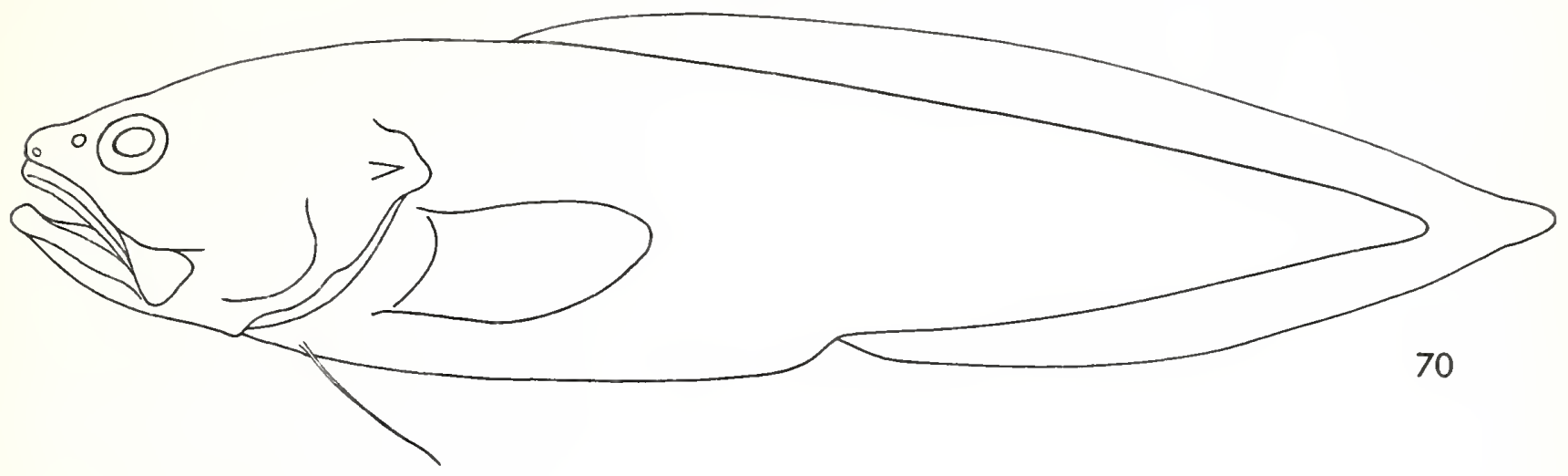

Abvthites Nielsen and Cohen (1973:82; type-species by original designation Bythites lepidogenys Smith and Rad(liffe).

Body short and robust, depth at vent 4 to 5 times in standard length. Eye large, 4 to 5 times in head length, slightly shorter than snout. Scales present on head. Opercular spine strong. Teeth granular. Palatine teeth present. Developed rakers on anterior gill arch 3 . Ventral fins with 1 ray in each. Pectoral fin rays 22 to 24 . Caudal fin rays 10 . Branchiostegal ravs 8 . Precaudal vertebrae 13 or 14 . Male with a stalked intromittent organ.

Close to Catrety.x. See Propteridium for further discussion.

Western Pacific and off Madagascar at depths ranging from 100 to $400 \mathrm{~m}$.

A single species. most recently treated by Nielsen and Cohen (1973), *A. lepidogenys (Smith and Radcliffe in Radcliffe 1913) (*Bithites matsubarai Arai 1969 is a synonym).

\section{Bellottia Giglioli}

(Fig. 71)

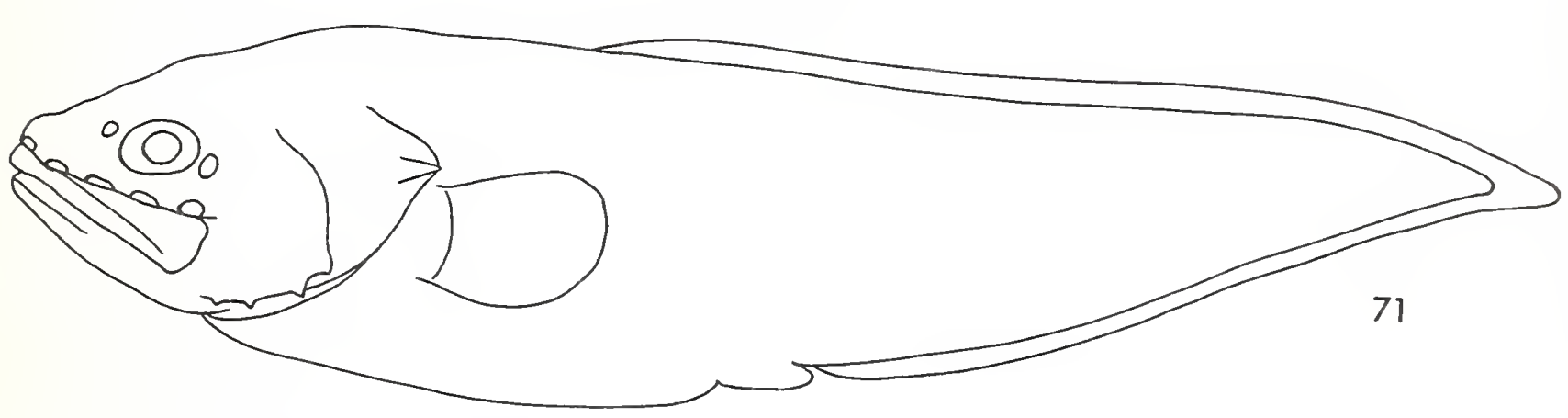

Bellottia Giglioli (1883:399; type-species by monotypy Bellottia apoda Giglioli).

Xenobythites Smith and Radcliffe in Radcliffe (1913:173; type-species by original designation Xenobythites armiger Smith and Radcliffe).

Ventral fins absent. Several sharp spines at lower angle of preopercle. Scales present on head. Palatine teeth present. Developed rakers on anterior gill arch 3 to 6 . Pectoral fin rays 22 or 23 . Precaudal vertebrae 10 to 12.

Perhaps related to Abvthites.

North Atlantic, Mediterranean, and western Pacific at depths ranging from 30 to $527 \mathrm{~m}$.

Two nominal species: ${ }^{*} B$. apoda Giglioli 1883, ${ }^{*} B$. armiger (Smith and Radcliffe in Radciiffe 1913), and perhaps another. undescribed one. Recent descriptions have been presented by Nielsen and Cohen (1968) and Maul (1976). The genus is being further studied by D. Cohen and R. G. Gilmore. 


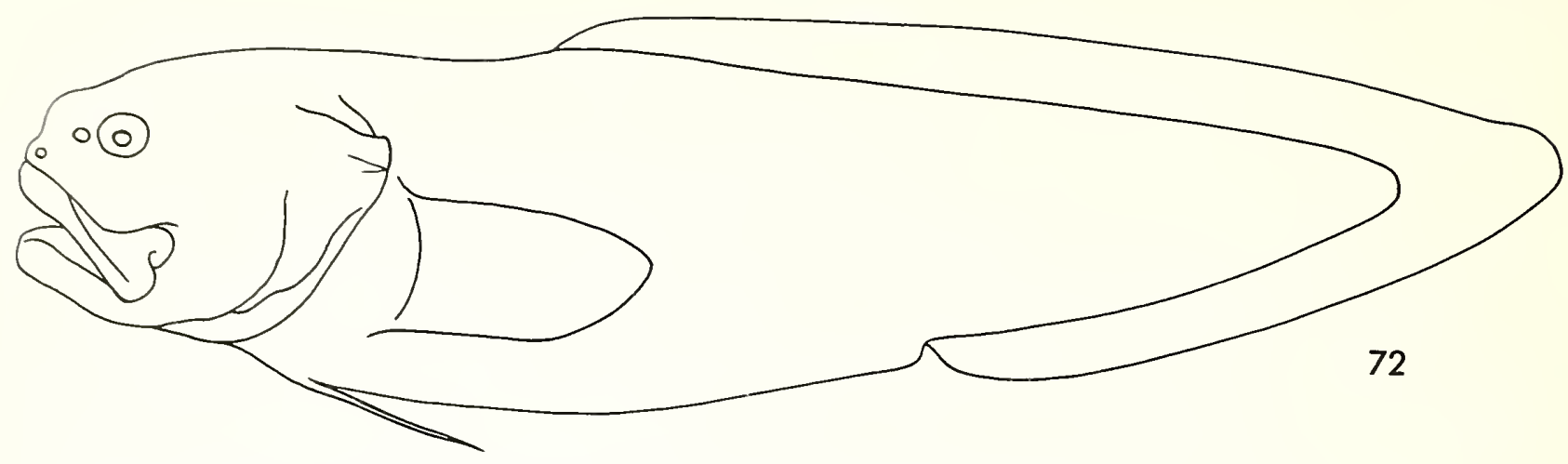

Bvthitr: Reinhardt (1835:7: type-species by monotypy Bvthites fuscus Reinhardt).

Budv short. depth at vent 5 to 6 times in standard length. Preanal long, anal fin originating on posterior half of body. Opercular spine strong. Teeth somewhat separate, needlelike. Palatine teeth present. Head naked. Developed rakers on anterior grill arch 0 or 1 . Ventral fins with 1 ray in each. Pectoral fin rays 24 to 30 . Caudal fin rays 10 to 12 . Branchio-tegal raw 7 or 8 . Precaudal vertebrae 14 or 15 . Male with a stalked intromittent organ.

Perhaps related to Diplacanthopoma.

Taken off Tceland and in the western Atlantic from west Greenland to Florida at depths ranging from 200 to $800 \mathrm{~m}$.

A recent revision by Neilsen and Cohen (1973) recognized three species: ${ }^{*} B$. fuscus Reinhardt $1837,{ }^{*}$ B. gerdae Niel-fn and Cohen 1973, and ${ }^{*} B$. islandicus Nielsen and Cohen 1973.

\section{Calamopteryx Böhlke and Cohen}

(Fig. 73)

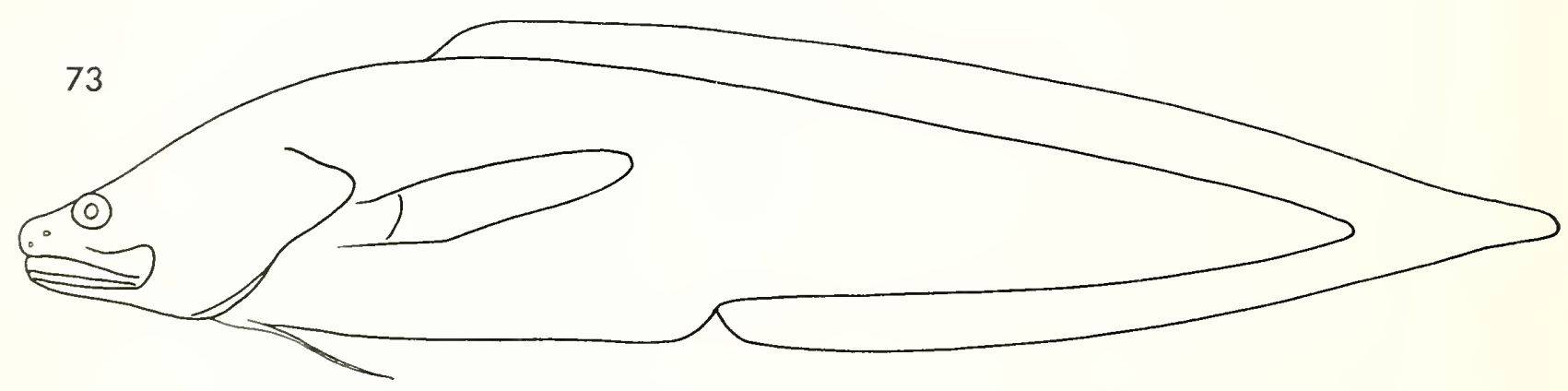

Colamoptrom'x Böhlke and Cohen (1966:2; type-species by original designation Calamopteryx goslinei).

Pectoral fin supported hy an elongate peduncle. Preanal distance long, anal fin origin on posterior half of body. Prenpercle with a curved, anteriorly directed spine at the lower angle. Opercular spine flattened and flaplike. Palatine teeth present. Scales present on head. Developed rakers on first gill arch 2 or 3 . Ventral fins with 1 ray in each. Pectoral fin rays 1.3 to 19. Caudal fin rays 8 to 10 . Branchiostegal rays 7 . Precaudal vertebrae 10 or 11.

Tropical western North Atlantic and Galapagos Islands from the intertidal to $220 \mathrm{~m}$.

Three species: *C, goslinei Böhlke and Cohen 1966, ${ }^{*}$ C. jeb Cohen 1973, and *C. robinsorum Cohen 1973.

\section{Cataetyx Günther}

(Fig. 74)

('rutuetvx Ciüther (1887:104; type-species by monotypy Sirembo messieri Günther).

(1)ulospinus Knefoed (1927:137; type-species by monotypy Oculospinus brevis Koefoed).

Scales present on head. Opercular spine strong. Most species with a sharp spine on cleithrurn above upper pectoral rav. I ateral et hmoid variously developed in front of or below eye, ranging from a sharp, retrorse emergent spine to a burried cartilaginous knob. Palatine teeth present. Developed rakers on first arch 3 . Ventral fins with 1 ray in each. Pectrral fin rays 25 to 32 . Caudal fin rays 8 to 11 . Branchiostegal rays 8 or 9 . Precaudal vertebrae 13 to 16 . 


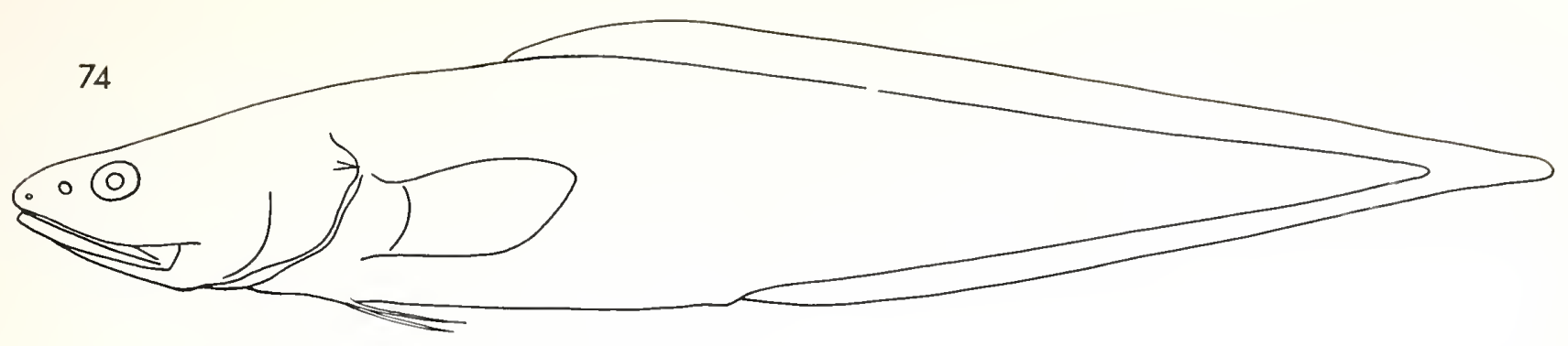

Found around the world in tropical and temperate seas at depths ranging from the continental shelf to the abyss.

Cataety $x$ is much in need of revision and is being studied by D. M. Cohen. In a recent paper, Meyer-Rochow (1970) presented a key to the species, taken mostly from the literature and containing many inaccuracies. He included two species that we refer to Pseudonus and omitted two species that were previously included in a distinct genus Oculospinus. We consider Oculospinus to be a junior synonym of Cataetyx, as specimens of the latter genus also have the retrorse spine on the lateral ethmoid that is the chief diagnostic character of Oculospinus. As here characterized, Cataetv $x$ is highly diverse and further study may give reason to recognize more than one genus. For the present we include the following 8 nominal species (there is at least one other, undescribed one): ${ }^{*}$ C. alleni (Byrne 1906) (which has as synonyms ? Crammonus leucos Osorio 1917 and *Oculospinus brevis Koefoed 1927), *C. bruuni (Nielsen and Nybelin 1963), ${ }^{*} \mathrm{C}$. hawailensis Gosline $1954,{ }^{*} \mathrm{C}$. laticeps Koefoed $1927,{ }^{*} \mathrm{C}$. memoriabilis Meyer-Rochow $1970,{ }^{*} \mathrm{C}$. messieri (Günther 1887), ${ }^{*}$ C. rubrirostris Gilbert 1890 , and ${ }^{*}$ C. simus Garman 1899.

\section{Diplacanthopoma Günther}

(Fig. 75)

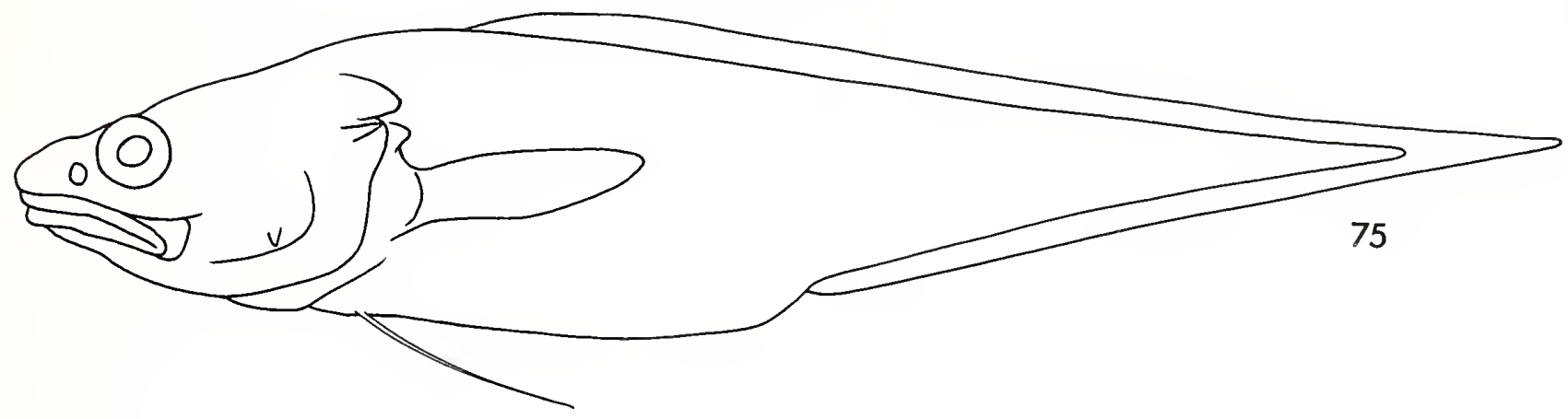

Diplacanthopoma Günther (1887:115; type-species by monotypy Diplacanthopoma brachysoma Günther).

Mvxocephalus Steindachner and Döderlein (1887:281; type-species by monotypy Myxocephalus japonicus Steindachner and Döderlein).

Sarcocara Smith and Radcliffe in Radcliffe (1913:167; type-species by original designation Diplacanthopoma (Sarcocara) brunnea Smith and Radcliffe).

Scales absent from head and bases of dorsal and anal fins. Opercular spine strong. A prominent, pore-bearing skin flap over the opercle (Fig. 68). Jaw teeth granular. Palatine teeth present. Developed rakers on first arch 3 or 4 . Ventral fins with 1 ray in each. Pectoral fin rays 21 to 28 . Branchiostegal rays 8 . Precaudal vertebrae 14 to 19 .

Found around the world in temperate and tropical seas ranging from the continental shelf to the abyss.

This genus, which is much in need of revision, is being studied by D. M. Cohen. The following 8 nominal species are tentatively referred to the genus (there appear to be one or more undescribed ones): D. alcockii Goode and Bean 1896, ${ }^{*} D$. brachysoma Günther $1887,{ }^{*} D$. brunnea Smith and Radcliffe in Radcliffe 1913, * $D$. japonicus (Steindachner and Döderlein 1887), ${ }^{*} D$. jordani Garman 1899, D. nigripinnis Gilchrist and von Bonde 1924, ${ }^{*} D$. raniceps Alcock 1898 , and *D. rivers-andersoni Alcock 1895 .

\section{Grammonoides Smith}

(Fig. 76)

Grammonoides Smith (1947:343; type-species by original designation Grammonus opisthodon Smith).

Opercular spine strong. Palatine teeth absent. Jaw teeth separate, pointed, conical in an irregular row. Developed 


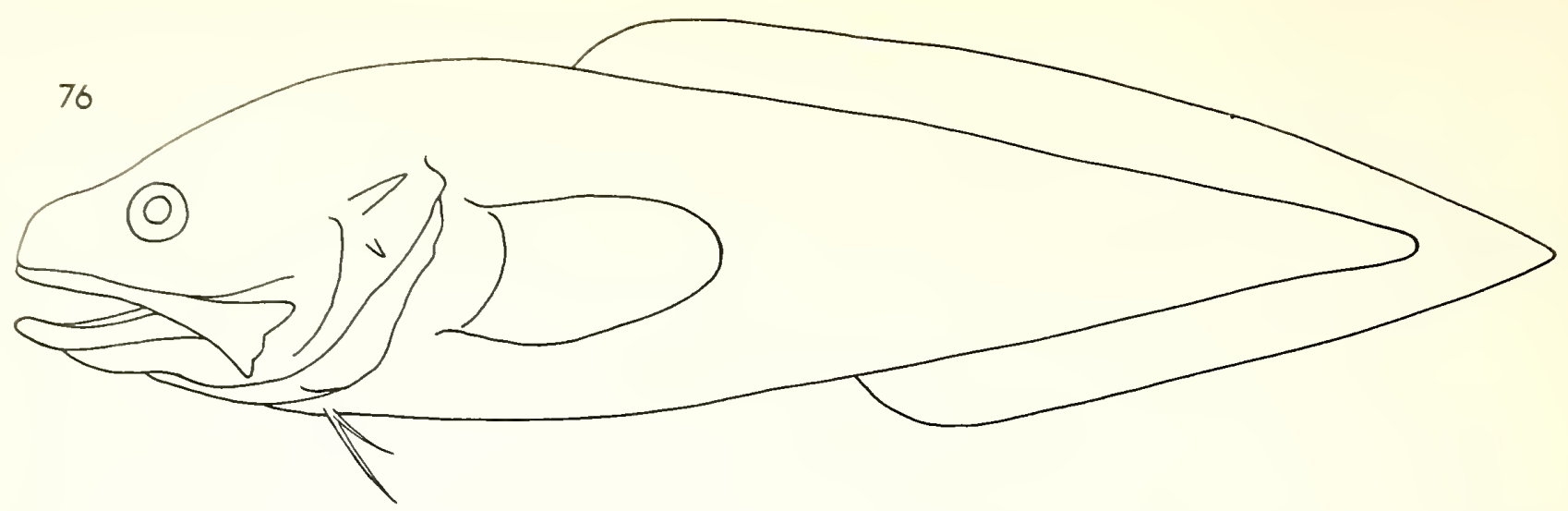

rakers on first gill arch 3. Pectoral fin rays 23. Branchiostegal rays 8. Precaudal vertebrae 13 . Neural spines on precaudal centra bluntly pointed.

Apparently close to Oligopus.

Indian Ocean. Port Alfred, South Africa.

A single species, *Grammonoides opisthodon (Smith 1934), based on one specimen in poor condition.

Hephthocara Alcock

(Fig. 77)

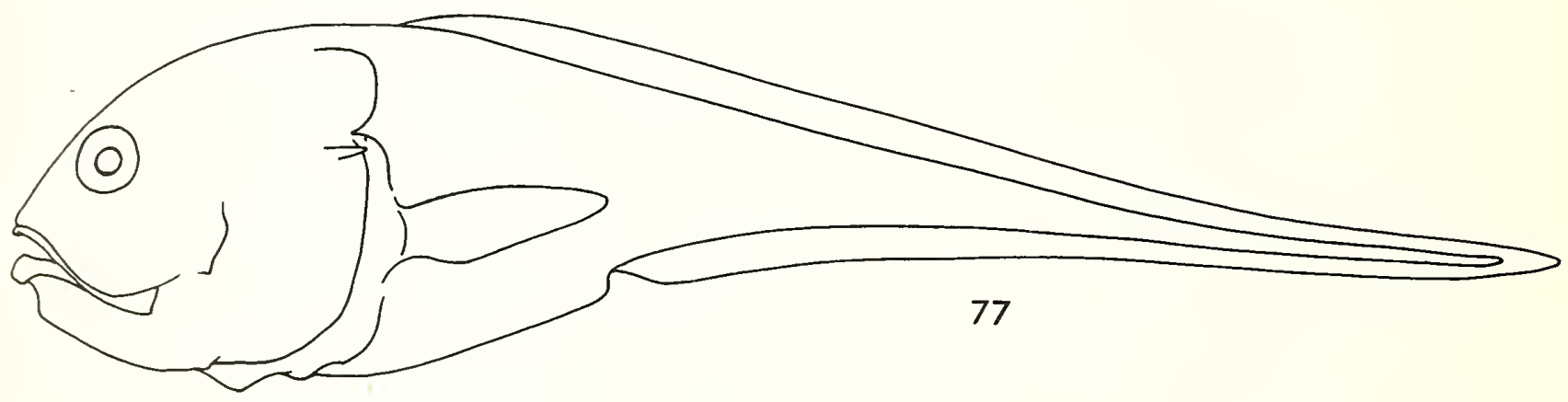

Hephthocara Alcock (1892:349; type-species by monotypy Hephthocara simum Alcock).

Ventral fins absent. Scales absent from head, which is very deep, and from fin bases. Head bones, including opercular spine. weak and soft; skin diaphanous. A very large pore-bearing flap over the opercle. Jaw teeth granular, in narrow bands on the vomer and palatines. Developed rakers on first arch 3 or 4 . Pectoral fin rays 16 to 19 . Caudal fin rays 6 or 7 .

Branchiostegal rays 8 . Precaudal vertebrae 18 to 21 .

Derived from Diplacanthopoma.

Indo-Pacific from Bay of Bengal to South America on the continental slope.

This genus is being studied by J. G. Nielsen. Two described species and another undescribed: ${ }^{*} H$. crassiceps Smith and Radcliffe in Radcliffe 1913, and ${ }^{*} H$. simum Alcock 1892.

Microbrotula Gosline

(Fig. 78)

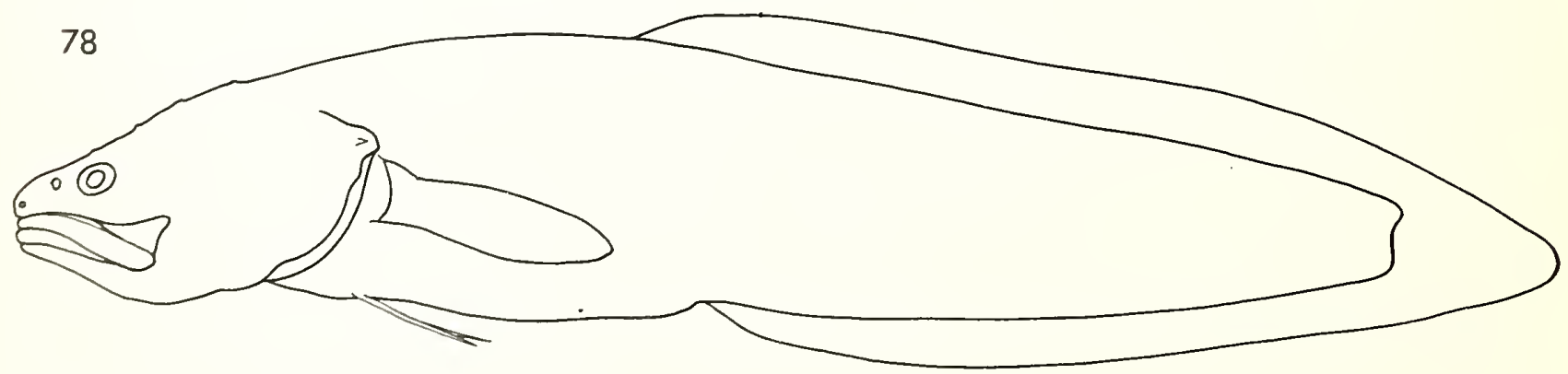


Microbrotula Gosline (1953:218; type-species by original designation Microbrotula rubra Gosline).

Scales present on head. Spine on opercle sharp and needlelike. Palatine teeth present. Developed rakers on first gill arch 3 or 4 . Ventral fins with 1 ray in each. Pectoral fin rays 11 to 14 . Branchiostegal rays 7. Precaudal vertebrae 11 or 12. Tiny fishes, reaching only about $45 \mathrm{~mm}$ in standard length.

Possibly a shallow-water derivative of Cataetyx.

Red Sea to Hawaii in reef areas at depths of 1 to $55 \mathrm{~m}$.

The genus is being studied by D. M. Cohen. Two described species (and possibly one or two others): *M. randalli Cohen and Wourms 1976, and *M. rubra Gosline 1953.

Oligopus Risso

(Fig. 79)

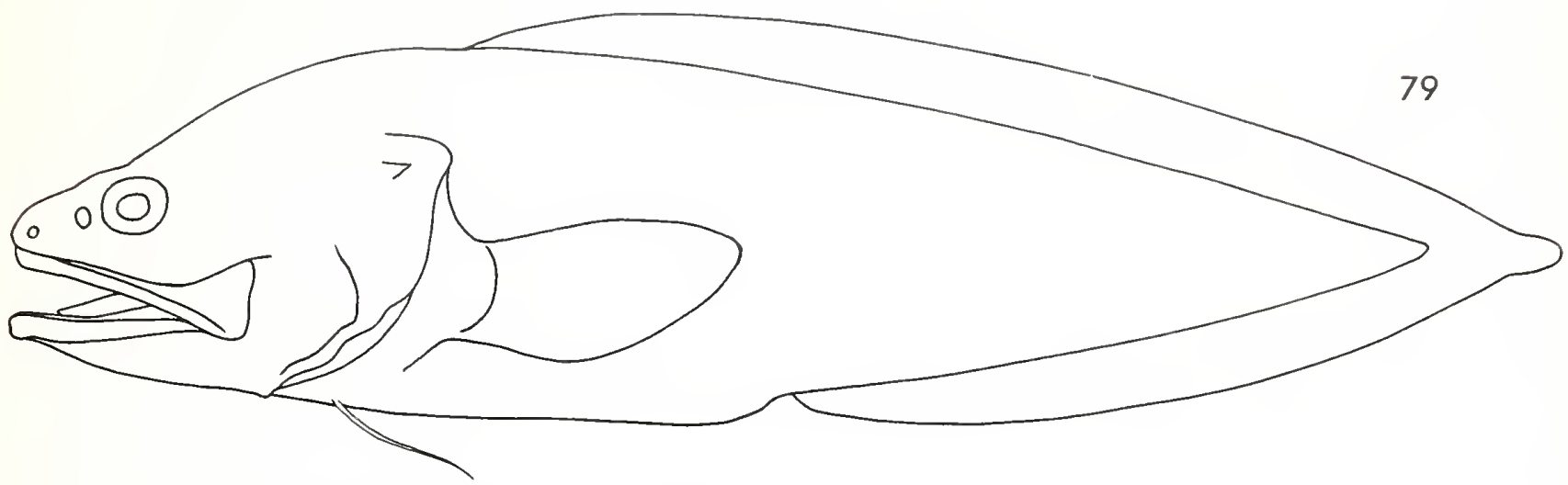

Oligopus Risso (1810:142; type-species by monotypy Oligopus ater Risso).

Gadopsis (not Agassiz 1845; not Richardson 1848) Filippi and Kölliker (1856:170; type-species by monotypy Oligopus ater Risso).

Grammonus Gill in Goode and Bean (1896:317; type-species by monotypy Oligopus ater Risso).

Verater Jordan (1919:343; type-species by original designation Oligopus ater Risso).

Eutvx Heller and Snodgrass (1903:224; type-species by monotypy Eutyx diagrammus Heller and Snodgrass).

Bathy'storreus Howell Rivero (1934:69; type-species by original designation Benthocometes claudei Torre).

Scales present on head. Palatine teeth absent. Developed rakers on first arch 2 or 3 . Ventral fins with 1 ray in each. Pectoral fin rays 19 to 29. Branchiostegal rays 8 . Precaudal vertebrae about 12 , with most neural spines truncate. Maxillary expanded posteriorly.

Oligopus may have been derived from a fish similar to Abythites, which it resembles in general body shape and in having truncate neural spines. The most notable difference is the absence of palatine teeth in Oligopus.

Circumtropical at depths ranging from the intertidal to $346 \mathrm{~m}$. The reproductive biology of $O$. longhursti has been discussed by Wourms and Cohen (1975).

The genus was revised by Cohen (1964b) who recognized the following 6 species: ${ }^{*} O$. ater Risso $1810(O$. niger Risso 1826 is a synonym), ${ }^{*} O$. claudei (Torre 1930$)\left({ }^{*}\right.$ Grammonus mowbrayi Grey 1951 is a synonym), ${ }^{*} O$. diagrammus (Heller and Snodgrass 1903), ${ }^{*} O$. longhursti Cohen $1964 \mathrm{~b},{ }^{*} O$. robustus (Smith and Radcliffe in Radcliffe 1913), and ${ }^{*} O$. waikiki Cohen 1964b ( ${ }^{*}$ Microbrotula nigra Gosline 1953 is a synonym).

\section{Propteridium Arambourg}

Propteridium Arambourg (1967:130; type-species by monotypy Urenchelys douvillei Priem).

Scales present on body. Opercular spine present. Palatine teeth present. Jaw teeth somewhat enlarged, relatively widely spaced, not granular. Developed rakers on first arch 3 . Ventral fins with 2 rays in each. Branchiostegal rays 8 . Precaudal vertebrae about 12 , with neural spines rather pointed. Caudal fin rays 9 to 10 . Dorsal fin rays about 80 . Anal fin rays 63 or 64 .

This genus, from the middle Oligocene of Persia, is represented by very good material that we have been able to examine and thereby supplement the generally excellent account given by Arambourg (1967). In most of the characters listed above, Propteridium appears to be a relatively generalized fish for the subfamily and must surely be close to the stock from which Recent Bythitinae evolved. Of Recent genera it is probably as close to Abythites as to any, differing most notably in having 2 ventral rays in each fin rather than 1 and in having widely spaced needlelike jaw teeth rather than granular ones. 
(Fig. 80)

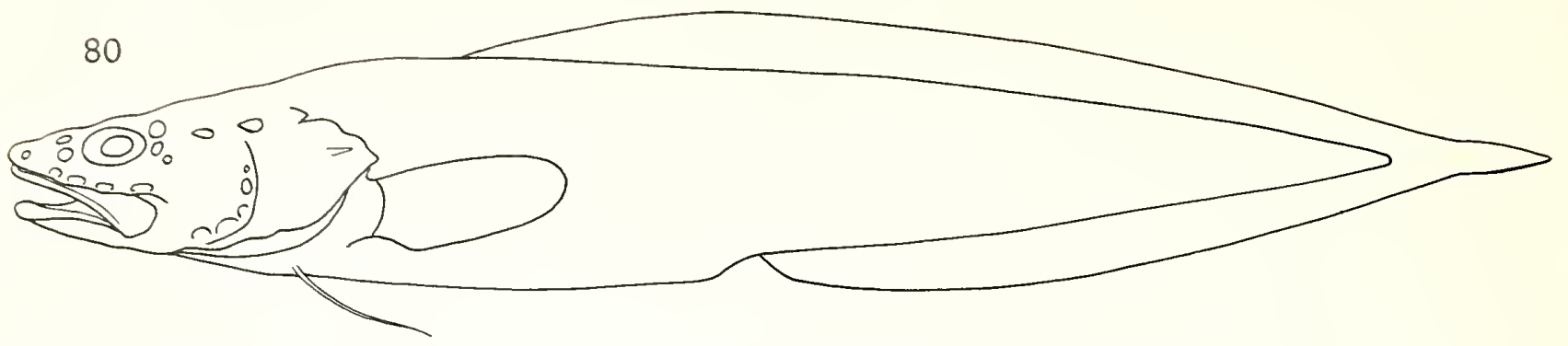

Pseudonus Garman (1899:169; type-species by monotypy Pseudonus acutus Garman).

Head pores prominent; a large elliptical median, interorbital pore. Head depressed. Scales present on head. Opercular spine strong. Cleithrum with a sharp spine projecting above the upper pectoral ray. Lateral ethmoid with a blunt cartilaginous knob in front of eye. Jaw teeth granular. Palatine teeth present. Developed rakers on first arch 3 . Ventral fins absent or with 1 ray in each. Pectoral fin rays 18 to 22 . Caudal fin rays 7 to 9 . Branchiostegal rays 8 . Precaudal vertebrae 16 .

Derived from Cataetvx, some species of which it resembles, being separated chiefly by the development of the lateralis sistem on the head. Further work may show that species presently placed in Cataetyx should be transferred to this genus or that Pseudonus should be considered a subgenus of Cataetyx.

Arabian Sea to Panama on the continental slope.

This genus is being studied by D. M. Cohen. Known from fewer than a dozen specimens that are placed in 3 nominal species: ${ }^{*}$ P. acutus Garman 1899, ${ }^{*} P$. platycephalus (Smith and Radcliffe in Radcliffe 1913), and ${ }^{*} P$. squamiceps (Lloyd 1909).

\section{Saccogaster Alcock}

(Fig. 81)

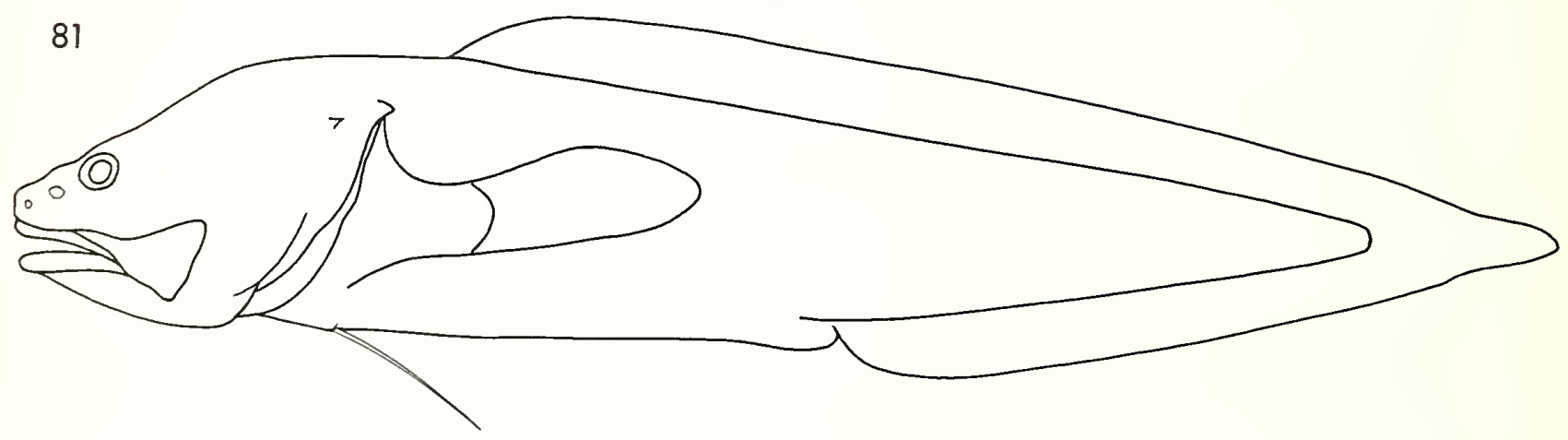

Saccogaster Alcock (1889:389; type-species by monotypy Saccogaster maculatus Alcock).

Barbuliceps Chan (1966:4; type-species by original designation Barbuliceps tubercularis Chan, error for tuberculatus).

Scales absent from head, reduced or absent on body. Pectoral fin supported by elongate radials. Opercular spine present. Jaw teeth granular. Palatine teeth present. Developed rakers on first gill arch 0 to 6 . Ventral fins with 1 ray in each. Pectoral fin rays 14 to 23 . Branchiostegal rays 8 . Precaudal vertebrae 12 to 16 . Males with a stalked intromittent organ.

Perhaps derived from Diplacanthopoma.

Rarely taken circumtropical fishes caught at depths ranging from about 100 to $800 \mathrm{~m}$.

The genus has been revised by Cohen and Nielsen (1972) who recognized the following six species: * $S$. hawaii Cohen and Nielsen 1972, *S. maculata Alcock 1889, *S. normae Cohen and Nielsen 1972, ${ }^{*}$ S. parva Cohen and Nielsen $1972^{7}$, ${ }^{*}$ S. staigeri Cohen and Nielsen 1972, and ${ }^{*}$ S. tuberculata (Chan 1966).

Corrected type-locality for this species: lat. $24^{\circ} 21^{\prime} \mathrm{S}$, long. $43^{\circ} 54^{\prime} \mathrm{W}, 500 \mathrm{~m}$. 


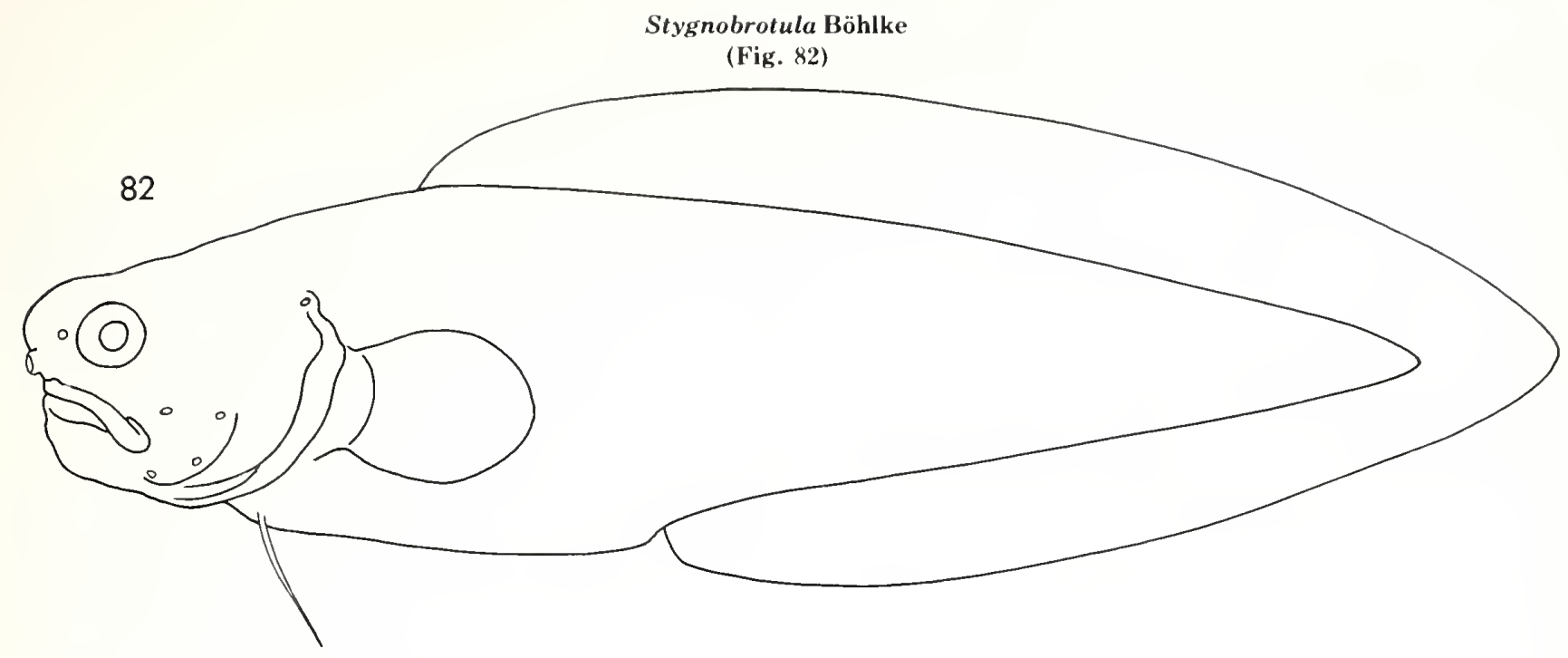

Stvgnobrotula Böhlke (1957:1; type-species by original designation Stygnobrotula latebricola Böhlke).

Head and bodv notably compressed. Anterior profile of head quite blunt. Maxillary narrow posteriorly. Scales present on head. Anterior nostril slightly above upper lip. Some enlarged jaw teeth. Palatine teeth absent. Developed rakers on first gill arch 3 or 4 . Ventral fins with 1 ray in each. Pectoral fin rays 21 to 23. Caudal fin rays 6 . Branchiostegal rays 7 . Precaudal vertebrae 14 , with pointed neural spines.

Apparently derived from Oligopus.

Found in tropical western North Atlantic reefs.

A single species, ${ }^{*} S$. latebricola Böhlke $1957\left({ }^{*}\right.$ Eutyx tumidirostris Boeseman 1960 is a synonym).

Thalassobathia Cohen

(Fig. 83)

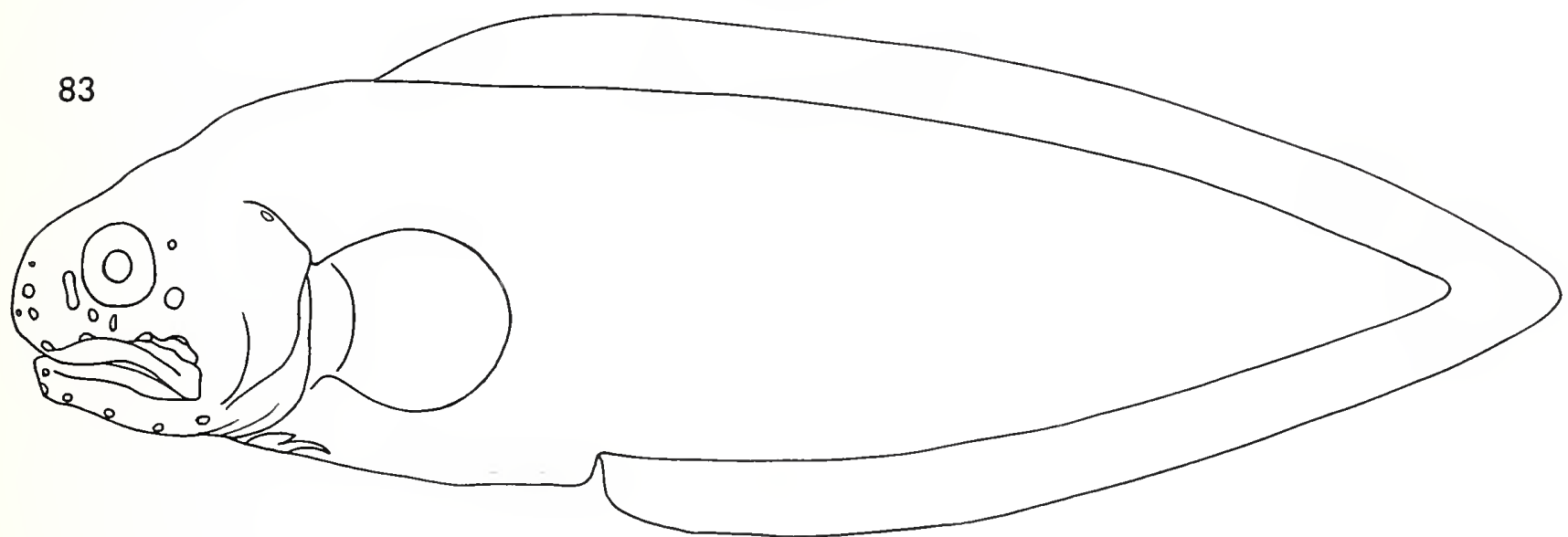

Thalassobathia Cohen (1963:1; type-species by original designation Thalassobathia pelagica).

Ventral fins with 2 rays in each, the fins diverging from each other and covered with thick, fleshy skin. Head and body compressed. Anterior profile of head blunt. Scales absent from head and reduced or absent on body. Anterior nostril lacking a tube and placed high on snout. Maxillary narrow posteriorly. Bones poorly ossified. Skin thick. Jaw teeth needlelike. Palatine teeth present, but patch short. Pectoral fin rays 19 to 27 . Caudal fin rays 10 . Branchiostegal rays 7 . Precaudal vertebrae 12 , with pointed neural spines.

Although the pelagic Thalassobathia and the tiny reef-dwelling Stygnobrotula are distinct in several important respects, they bear an astonishing resemblance to each other. We cannot say whether they are in fact closely related.

Thalassobathia is one of the few bythitoids with an elevated anterior nostril. A low-placed nostril would not appear to have functional significance for a pelagic fish. 
Caught in the tropical and North Atlantic and the southeast Pacific. Possibly living in association with a large scyphozonan jelly tish (Harbison et al. 1973).

Two species: *T. nelsoni Lee 1974, and ${ }^{*} T$. pelagica Cohen 1963.

\section{BROSMOPHYCINAE GILL 1862}

Caudal fin free from dorsal and anal fins, although the anal fin may be basally connected in some species (Lucifuga is particularly variable with respect to this character, having at most a very short caudal peduncle). Male intromittent organ with or without ossified parts. Squamation on head and body complete or not. Ventral fins closely adjacent, with a single rav in each.

Mostly: small. shallow-water, reef-dwelling fishes, some living in fresh waters.

\section{Key to Tribes of Brosmophycinae}

1a. Male intromittent organ without ossified parts $\ldots \ldots \ldots$ Brosmophycini

1b. Male intromittent organ with one or more pairs of ossified pseudoclaspers (Fig. 84) _... Dinematichthyini

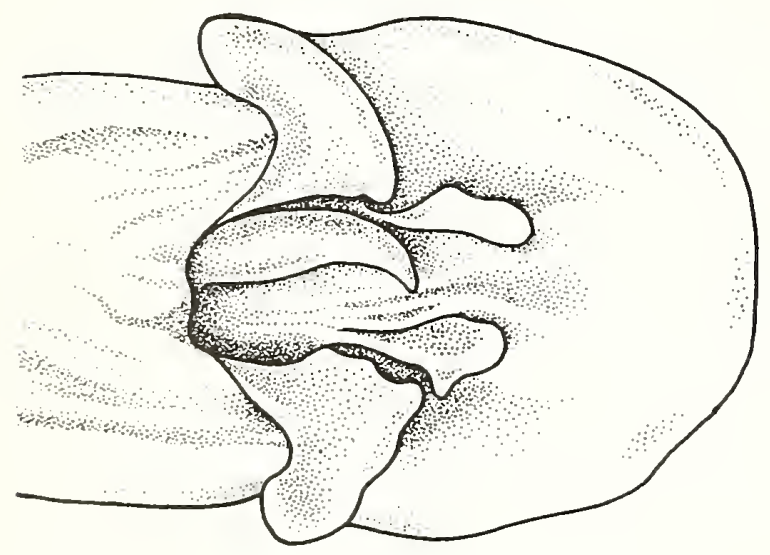

Figure 84 .- Male intromittent organ (ventral view) in Ogilbia, a genus of Dinematichthyini; note the two pairs of ossified pseudoclaspers.

\section{Brosmophycini Gill 1862}

Male intromittent organ with no ossified parts. Body completely covered with imbricate scales. Developed rakers on first gill arch 3 or 4.

Possibly an artificial group.

Key to Genera of Brosmophycini

1a. Scales present on head Lucifuga

1h. Scales absent from head 2

2a. Anal fin origin well posterior to midlength of fish. Branchiostegal rays $8 \ldots \ldots$. . . . . . Bidenichthys

2h. Anal fin origin at about midlength of fish. Branchiostegal rays $7 \ldots \ldots$

3a. Eye diameter equal to or greater than snout length. Maxillary strongly sheathed posteriorly . Brosmophyciops

3h. Eye diameter less than snout length. Maxillary free pośteriorly . . . . . . . . . . . Brosmophycis 


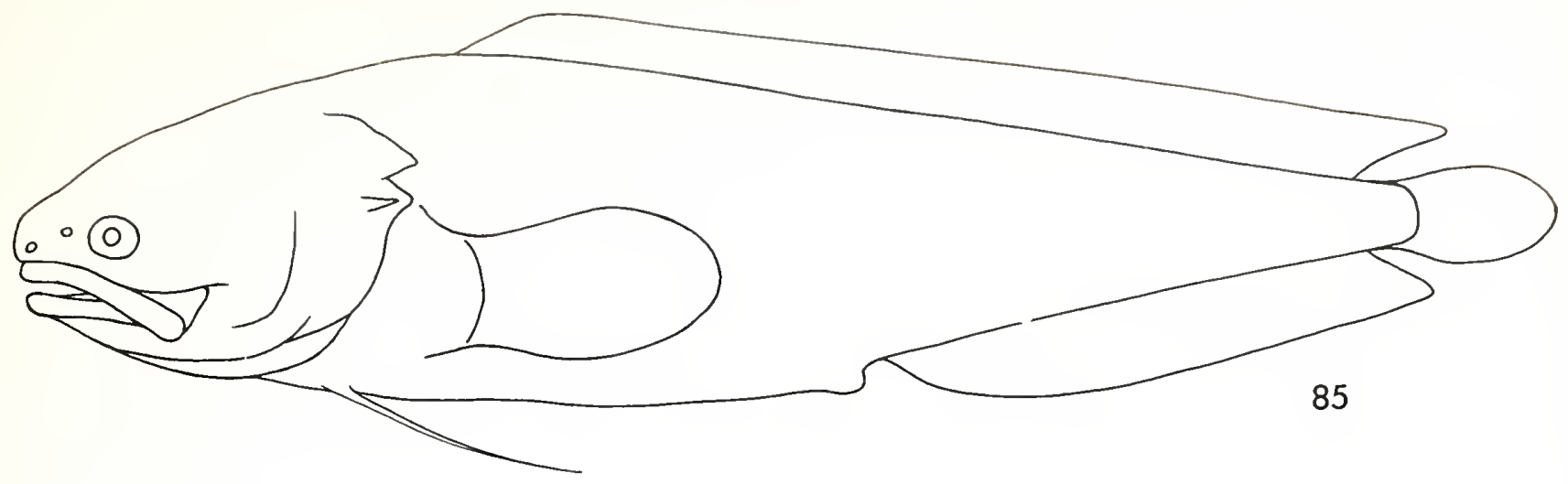

Bidenichthy's Barnard (1934:234; type-species by monotypy Bidenichthys capensis Barnard).

Anal fin origin far posterior to midlength of fish. Eye diameter less than snout length. Maxillary expanded and free posteriorly. Pectoral radials elongated, fin on a prominent peduncle. Jaw teeth needlelike, separate from each other. Branchiostegal rays 8 . Pectoral fin rays 21. Caudal fin rays 14 to 16 . Precaudal vertebrae 15.

Cape of Good Hope to East London in tide pools.

A single species, ${ }^{*} B$. capensis Barnard 1934.

\section{Brosmophyciops Schultz}

(Fig. 86)

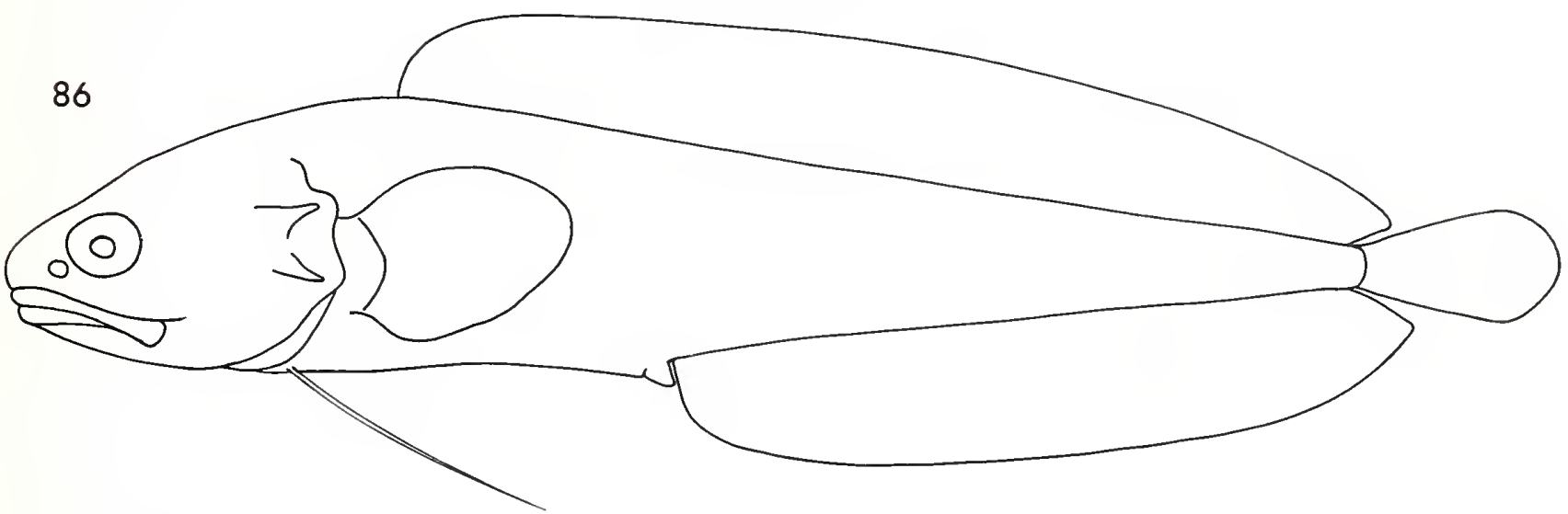

Brosmophyciops Schultz (1960:384; type-species by original designation Brosmophyciops pautzkei Schultz).

Anal fin origin at about midlength of fish. Eye diameter equal to or greater than snout length. Snout rounded, jaws inferior. Maxillary strongly sheathed. Pectoral fin on a broad peduncle, radials not elongated. Jaws with some teeth needlelike and elongated.

Branchiostegal rays 7. Pectoral fin rays 25 to 29 . Caudal fin rays 12 . Precaudal vertebrae 12 or 13 .

Tropical reefs from the Red Sea to the Marshall Islands and Samoa.

A single described species, ${ }^{*}$ B. pautzkei Schultz 1960, another unnamed. This genus is being studied by D. M. Cohen.

\section{Brosmophycis Gill}

(Fig. 87)

Brosmophycis Gill (1861b:168; type-species by original designation Brosmius marginatus Ayres).

Halias Ayres (1863:52; type-species by original designation Brosmius marginatus Ayres).

Anal fin origin at about midlength of fish. Thick skin over head, body, and fins. Eye diameter less than snout length. Pectoral fin on a broad peduncle, radials not elongated. Jaw teeth mostly needlelike and discrete. Branchiostegal rays 7. Pectoral fin rays 26. Caudal fin rays 16 . Precaudal vertebrae 16 or 17. 


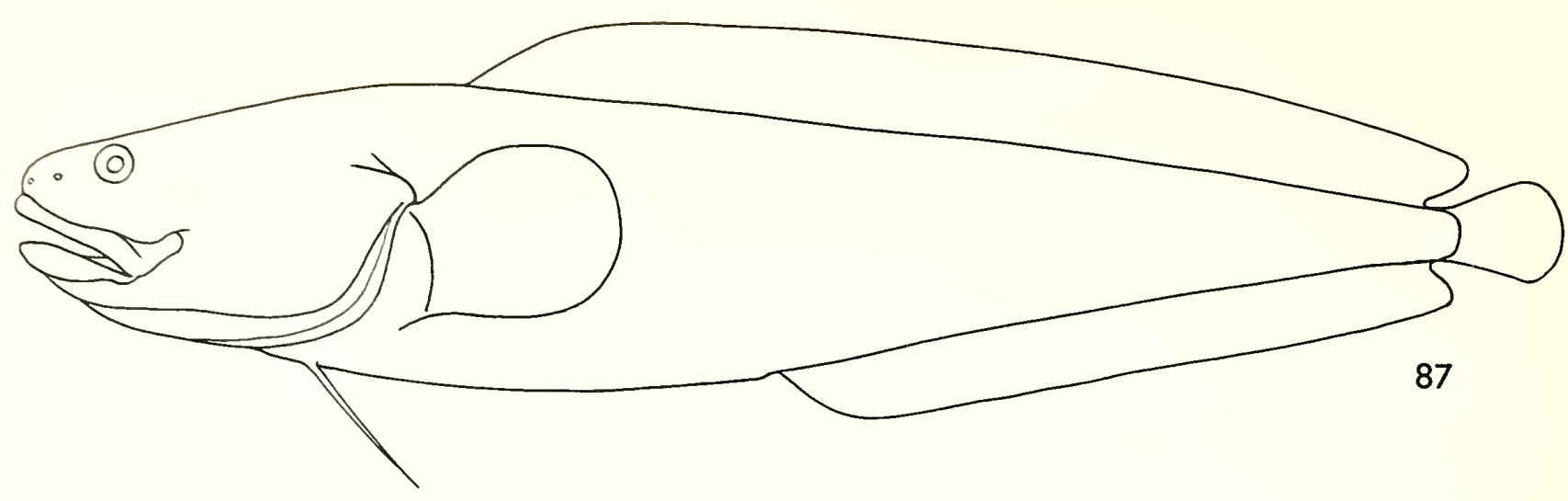

Temperate eastern North Pacific at depths of 3 to $256 \mathrm{~m}$. Recent records and meristics have been presented by Follett (1970).

A single described species, ${ }^{*} B$. marginata (Ayres 1854), perhaps another, undescribed.

\section{Lucifuga Poey}

(Fig. 88)

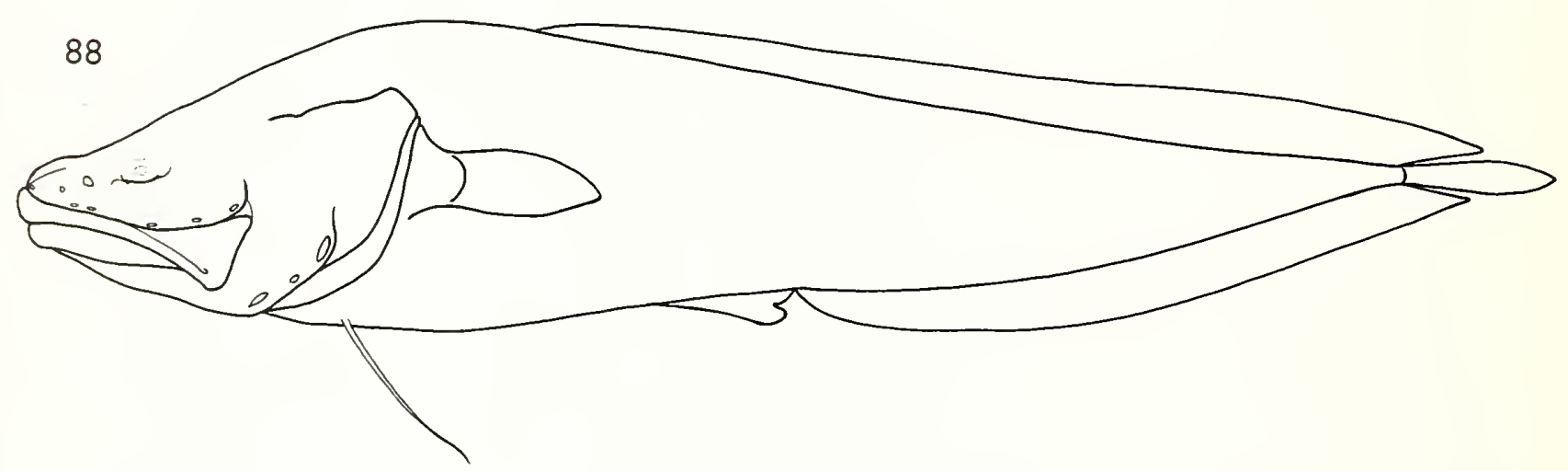

Lucifuga Poey (1858:95; type-species by subsequent designation of Jordan and Evermann 1896, Lucifuga subterraneus).

Stygicola Gill (1863a:252; type-species by monotypy Lucifuga dentatus Poey).

Scales present on head. Opercular spine flattened and weak. Palatine teeth present or absent. Jaw teeth granular. Pectoral fin rays 12 to 20. Caudal fin connected basally with dorsal and anal fins in some specimens, with 8 to 11 rays. Branchiostegal rays 7. Precaudal vertebrae 11 to 13 . Eyes poorly developed, often not externally visible.

Caves and sinkholes in limestone formations of Cuba and the Bahamas, where they are found in waters of various salinities ranging from fresh to highly saline.

The biology of Lucifuga in Cuba has been studied by Eigenmann (1909). The taxonomy of the genus has been treated most recently by Cohen and Robins (1970).

Three species in two subgenera are known; reports persist of other species in the Bahamas and Jamaica: ${ }^{*} L$. (Lucifuga) subterraneus Poey $1858,{ }^{*}$ L. (Stygicola) dentatus Poey 1858, and ${ }^{*} L$. (S.) spelaeotes Cohen and Robins 1970.

\section{Dinematichthyini Whitley 1928}

Male intromittent organ with one or more pairs of ossified pseudoclaspers (Fig. 84). Head scales present or absent. Body squamation complete, partial, or absent. Scales when present imbricate or not. Jaw teeth at least in part needlelike, not granular.

The distinguishing characteristics of Brotulina (including Calcarbrotula), Dinematichthys, Monothrix, and Ogilbia (including Caecogilbia and Typhliasina) are not at all clear. There are many undescribed species that can be assigned to these nominal genera and consequently scant knowledge is available of the range in variation of characters with potential diagnostic value in defining genera. When additional data are available it may be necessary to realign the genera. 
1a. Cill membranes free from isthmus. Maxillary more or less expanded vertically at its posterior end

1b. Gill membranes attached to the isthmus anteriorly. Maxillary not greatly expanded vertically at its posterior end

2a. Opercle lacking spines

Dermatopsoides

2b. Opercle with sharp-pointed spine, sometimes skin covered

3a. Ventral fins reaching vent

Diancistrus

3b. Ventral fins falling short of vent

4a. Branchiostegal rays 6. Scales absent from body. Head about 6.5 or more times in standard

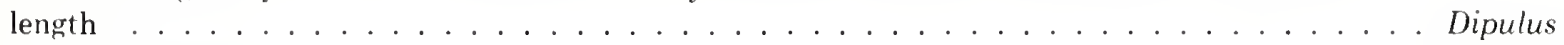

4h. Branchiostegal rays 7 . Scales present on body, sometimes imbedded. Head less than about 6.5 times in st andard length

Dermatopsis

5a. Anterior nostril rather high above upper lip, about midway between lip and posterior nostril (Fig. 89) Dinematichthys

5b. Anterior nostril closer to upper lip

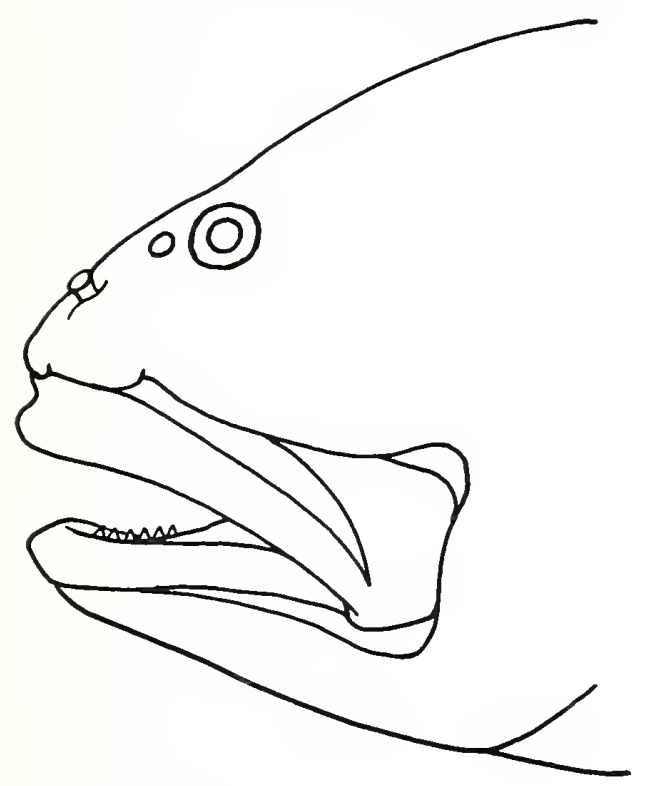

Figure 89. - Head of Dinematichthys showing the anterior nostril placed high above the upper lip.

6a. Branchiostegal rays 8 . Scales on body scarcely imbricate

Gunterichthys

6b. Branchiostegal rays 7 (rarely 8 on one side). Scales on body imbricate in most species 7

7a. Male intromittent organ with one pair of pseudoclaspers. Head naked ............. Monothrix

7b. Male intromittent organ with two or more pairs of pseudoclaspers. Head usually with scales, naked in a few species 


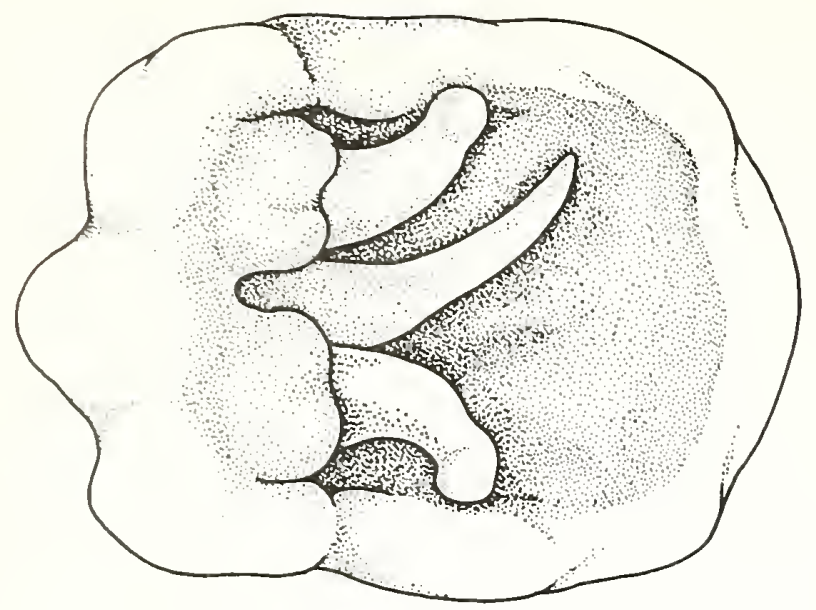

Figure 90.-Male intromittent organ (ventral view) in Brotulina; note that the largest pseudoclaspers are rounded prongs.

\section{Brotulina Fowler}

(Fig. 91)

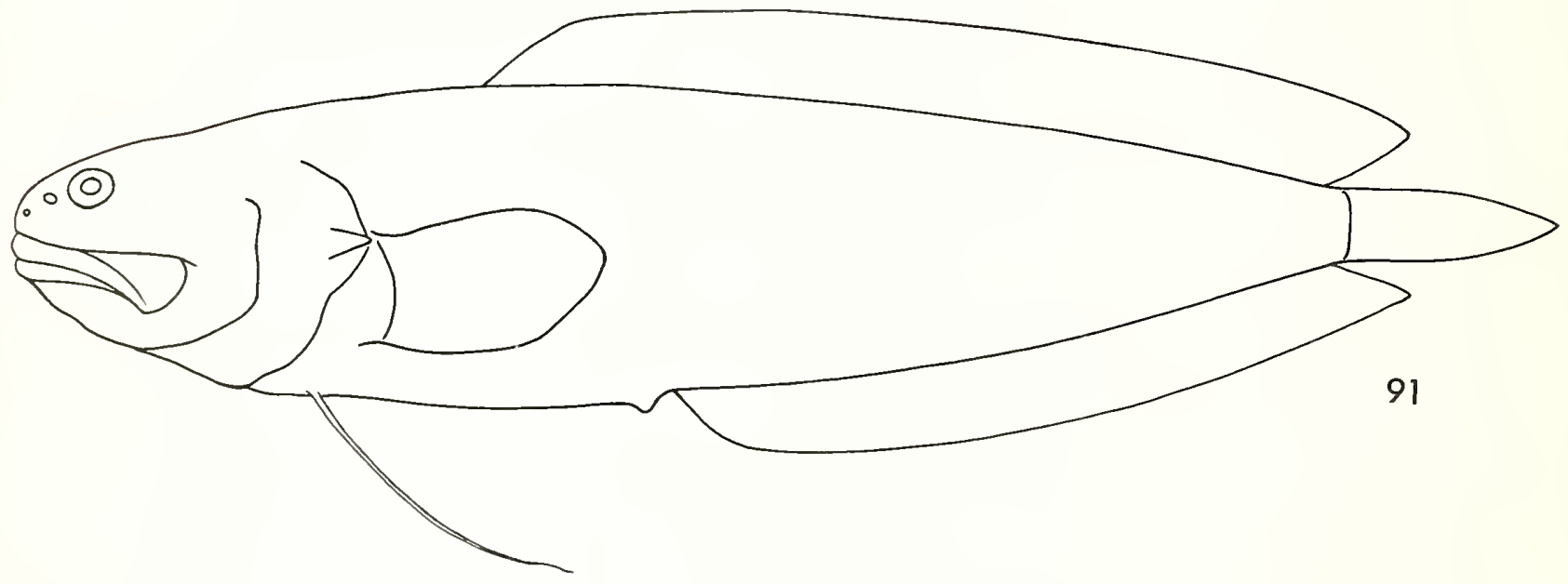

Brotulina Fowler (1946:195; type-species by original designation Brotulina fusca Fowler).

Calcarbrotula Fowler (1946:193; type-species by original designation Calcarbrotula erythrea Fowler).

Body scales imbricate. Head scales present on cheeks, absent from opercle. Gill membranes free from isthmus. A sharp spine present on opercle. Anterior nostril low, close to upper lip. Maxillary expanded posteriorly, its rear margin rounded. Intromittent organ of male with 2 pairs of pseudoclaspers, the largest rather rounded and pronglike (Fig. 90 ). Developed rakers on first gill arch 3. Branchiostegal rays 7 . Caudal fin rays 12 . Precaudal vertebrae 10 or 11 , some neural spines bluntly rounded to truncate.

Probably widespread on Indo-Pacific reefs.

The holotypes representing the first two names listed below are different sexes (fusca is a male) from the same locality and may belong to the same species (there is an unknown number of undescribed species): ${ }^{*} B$. erythrea (Fowler 1946$)$, ${ }^{\star}$ B. fusca Fowler 1946, and ? B. piger (Alcock 1890c).

\section{Dermatopsis Ogilby}

(Fig. 92)

Dermatropsis Ogilby (1896:138; type-species by monotypy Dermatopsis macrodon Ogilby).

Scales on body nonimbricate, absent from head. Gill membranes joined to isthmus anteriorly. Ventral fins falling far short of vent. Opercle with a sharp spine. Anterior nostril low, close to upper lip. Maxillary relatively narrow pos- 


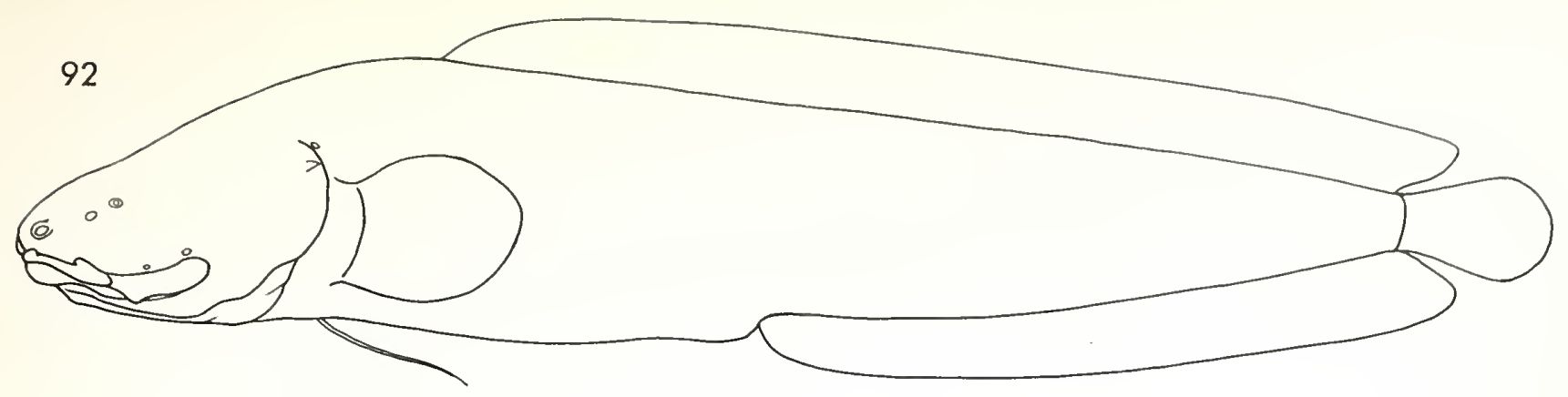

teriorly, not greatly expanded. Intromittent organ of male with one pair of flattened, pronglike pseudoclaspers, directed laterally at their distal ends. Developed rakers on first gill arch 2 to 4 . Branchiostegal rays 7 (incorrectly given as 6 by Cohen 1966). Caudal fin rays 16 or more. Pectoral fin rays 17 to 24 .

Temperate and subtropical shallow waters of Australia and New Zealand.

Two species were recognized by Cohen (1966), who reviewed the genus: ${ }^{*} D$. macrodon Ogilby 1896 , and ${ }^{*} D$. multiradiatus McCulloch and Waite 1918.

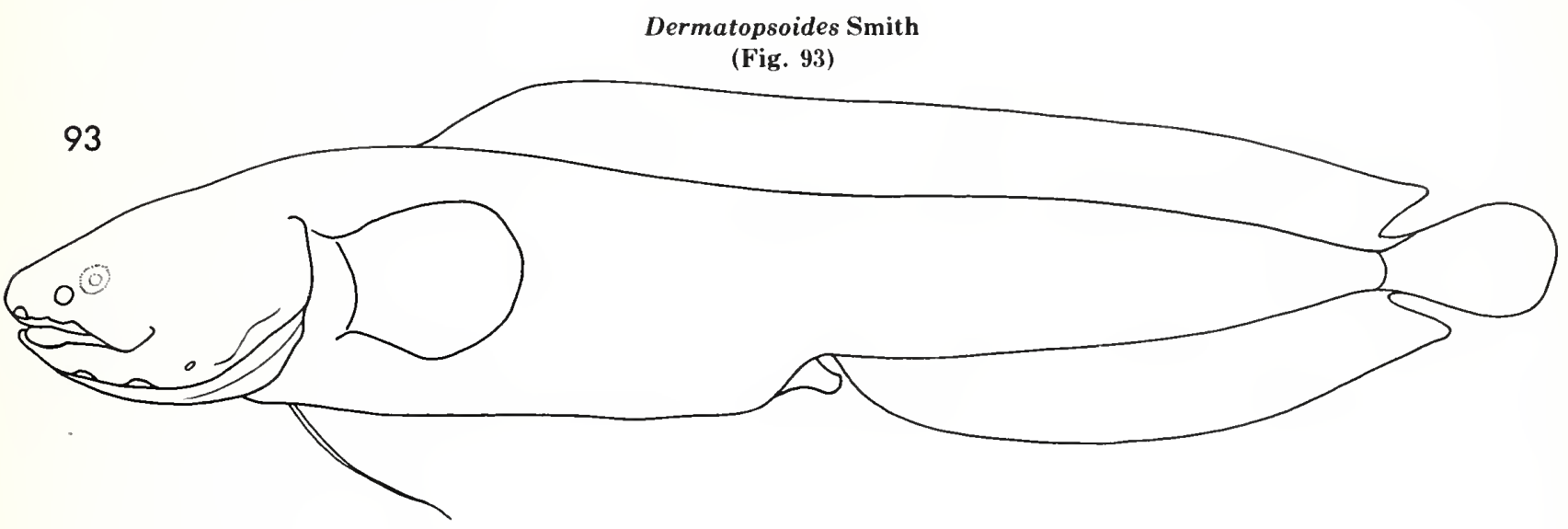

Dermatopsoides Smith (1947:361; type-species by original designation Dermatopsis kasougae Smith).

Scales absent or nonimbricate on body, absent or widely scattered on head. Eye minute, 11 or more times in head length. Gill membranes attached anteriorly to isthmus. Ventral fins falling short of anus. Opercular spine absent. Anterior nostril low, directly above upper lip. Maxillary narrow posteriorly, not expanded. Intromittent organ of male with a single pair of rounded, recurved pseudoclaspers, directed dorsally at their distal ends. Developed rakers on first arch 3. Branchiostegal rays 6. Pectoral fin rays 17 to 24 . Caudal fin rays 16 or more. Precaudal vertebrae 11 to 14 .

Apparently related to Dermatopsis.

Shallow waters of South Africa. Distribution is discussed by Smith (1966).

Two species were recognized by Cohen (1966): ${ }^{*} D$. kasougae (Smith 1943), and ${ }^{*} D$. talboti Cohen 1966.

\section{Diancistrus Ogilby}

Diancistrus Ogilby (1898:743; type-species by monotypy Diancistrus longifilis Ogilby).

Body scales present. Head naked. Ventral fins reaching vent. Opercle with a small spine. Maxillary spatulate. Intromittent organ of male with a single pair of curved pseudoclaspers. Branchiostegal rays 6. Pectoral fin rays 20.

Apparently related to Dermatopsis.

Lord Howe Island.

A single species, D. longifilis Ogilby 1898.

Dinematichthys Bleeker

(Fig. 94)

Dinematichthys Bleeker (1855:295; type-species by monotypy Dinematichthys iluocoeteoides Bleeker). 


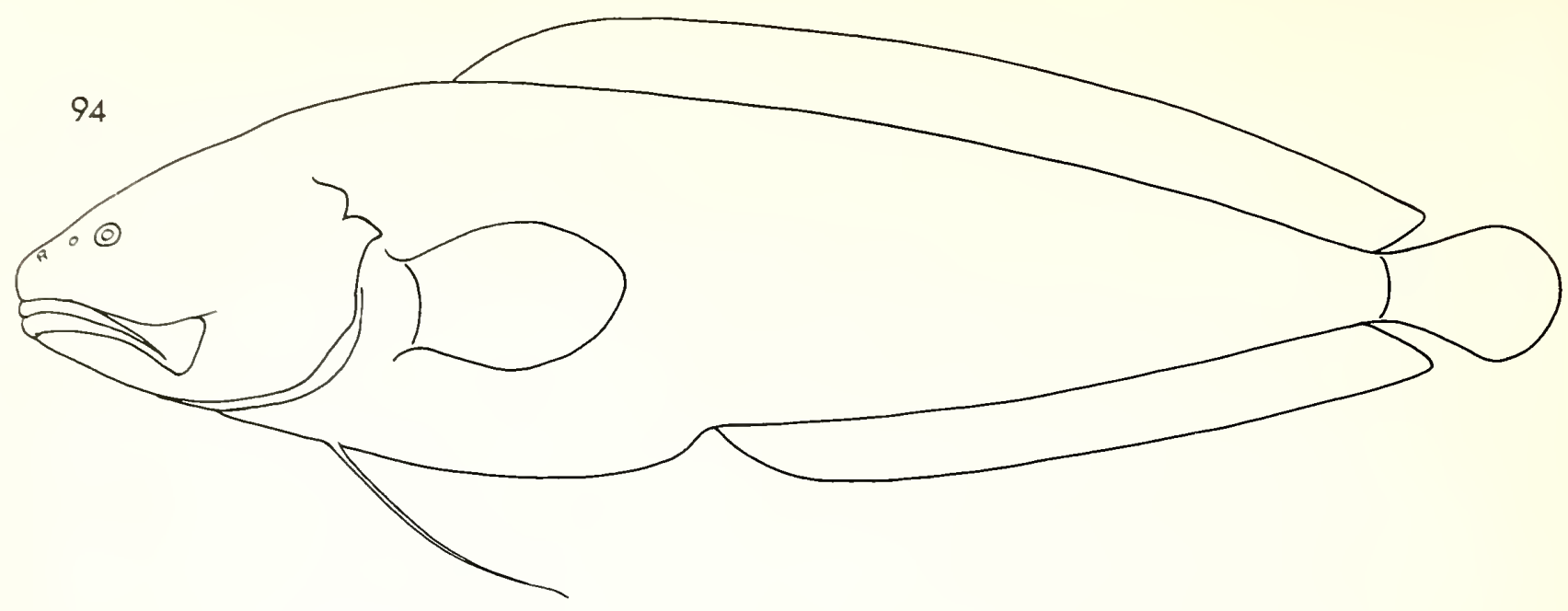

Bodr scales imbricate. Head squamation variable, ranging from the cheeks only to nearly the entire head. Some species with densely distributed papillae on the snout. A sharp spine present on opercle, sometimes buried. Anterior nostril relatively high. about midway between posterior nostril and upper lip. Maxillary expanded vertically at its posterior end. Intromittent organ of male with two or more pairs of pseudoclaspers, the largest a compressed ear-shaped lobe. Branchiostegal rays 7 . Some precaudal neural spines truncate.

I linematichthis is the earliest named genus of its tribe; hence, its definition is essential to achieving nomenclatural scability. Dinematichthys iluocoeteoides was described from a single specimen that apparently is no longer extant. A dnzen of Bleeker's specimens identified as D. iluocoeteoides were present at the Rijksmuseum van Natuurlijke Historie in Leiden but deteriorated and were discarded (M. Boeseman, pers. commun.). A Bleeker specimen identified as $D$. iluncoetenides was mentioned by Günther (1862) and is present in the British Museum (Natural History). We have examined the specimen, no. 1868.2.28.65, and find that considering its shriveled condition it agrees reasonably well with Bleetier's description with regard to squamation and size. Bleeker gave a length of $70 \mathrm{~mm}$; BMNH 1868.2.28.65 standard length $=62 \mathrm{~mm}$. Counts also are in close agreement; Bleeker: $\mathrm{D}=83, \mathrm{~A}=69$, pectoral $=22$ or $23 ; \mathrm{BMNH}: \mathrm{D}=84, \mathrm{~A}=68$, pectoral $=22$. There is, however, one important difference between the original description and the BMNH specimen. Bleeker noted a rather large eye, slightly more than 5 times in head length and slightly more than once in the interorhital width. The RMNH specimen has a small eye that enters the head 7.2 times and the interorbital 1.8 times. Furthermore. the BMNH specimen is a male with a prominent intromittent organ (2 pairs of ossified claspers, the larger a compressed lobe): no mention is made of this structure in Bleeker's original description. It seems unlikely that the British Museum specimen is the holotype.

Among a series of unpublished Bleeker plates in Leiden is a picture of a fish labeled Dinematichthys iluocoeteoides (Tab. CCCCXI. VI, fig. 9; a copy of this drawing has been published by DeBeaufort and Chapman 1951, fig. 79). The illustrated fish has a very small eye that enters the head 7.8 times; perhaps it shows a species that is conspecific with the British Museum specimen but different from the species originally described by Bleeker from a single specimen as $D$. $i l$ uricostenides. How then should the name Dinematichthys be assigned?

Among the dinematichthyine genera with imbricate body scales and an expanded maxillary are a number of species that have the anterior nostril placed high on the snout. Bleeker mentioned in his description of $D$. iluocoeteoides that the nostrils were close before the eye. He noted also the presence of head scales on the nape, preopercle, and opercle. Although some species with a high anterior nostril have scales only on the cheek, others have scales covering nearly the entire head. or coverage intermediate between the two extremes. Furthermore all males that we have seen, which have a high placed anterior nostril and head scales, have 2 or more ossified pseudoclaspers, the largest of which is a compressed. ear-shaped lobe. It seems reasonable therefore, to restrict usage of the name Dinematichthys to fishes that fall within the definition given above. The possibility should be investigated that a high anterior nostril has evolved independently in Old and New world Dinematichthys.

I „ow placement of the nostril is typical of the Bythitidae. One exception is Thalassobathia, for which we have suggested an explanation. In the present instance we can offer no explanation related to function but note that the occurrence of this character state is highly serendipitous for the taxonomist.

Inclo-Pacific and tropical western Atlantic reefs.

Probably numerous species, of which apparently only one has been described. Dinematichthys iluocoeteoides Bleeker 18.55 has been widely recorded in the literature; however, most occurrences are probably other species or genera. Reproductive biology has been discussed by Wourms and Bayne (1973). The genus is being studied by B. Walker. 


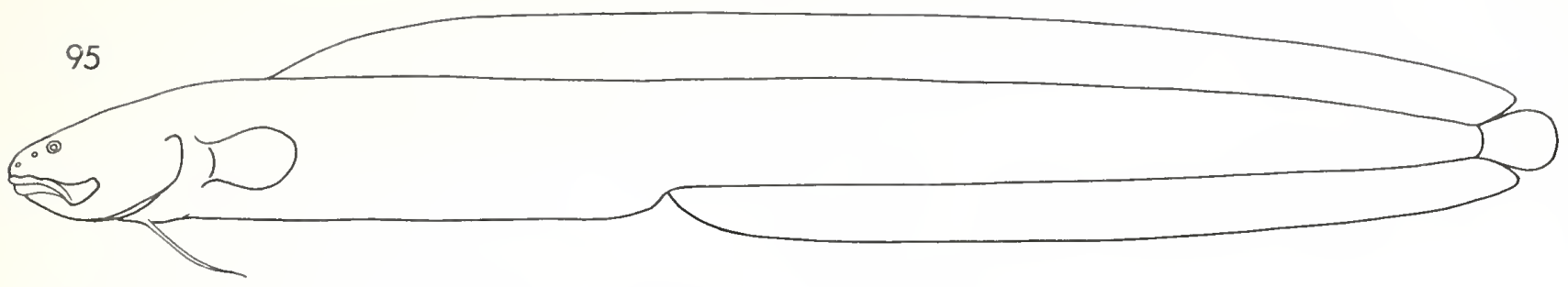

Dipulus Waite (1905:78; type-species by monotypy Dipulus caecus Waite).

Body elongate, head 6.5 or more times in standard length. Head and body without scales. Gill membranes joined to each other and to isthmus anteriorly. Ventral fins falling far short of vent. Opercle with a sharp spine. Anterior nostril low. close to upper lip. Maxillary relatively narrow posteriorly. Intromittent organ of male with a single pair of broad, convoluted pseudoclaspers. Branchiostegal rays 6. Pectoral fin rays about 20. Caudal fin rays 16 . Precaudal vertebrae 22.

Probably derived from Dermatopsis.

Temperate and subtropical Western Australia in shallow water.

A single species, ${ }^{*} D$. caecus Waite 1905 , discussed by Cohen (1966).

\section{Gunterichthys Dawson}

(Fig. 96)

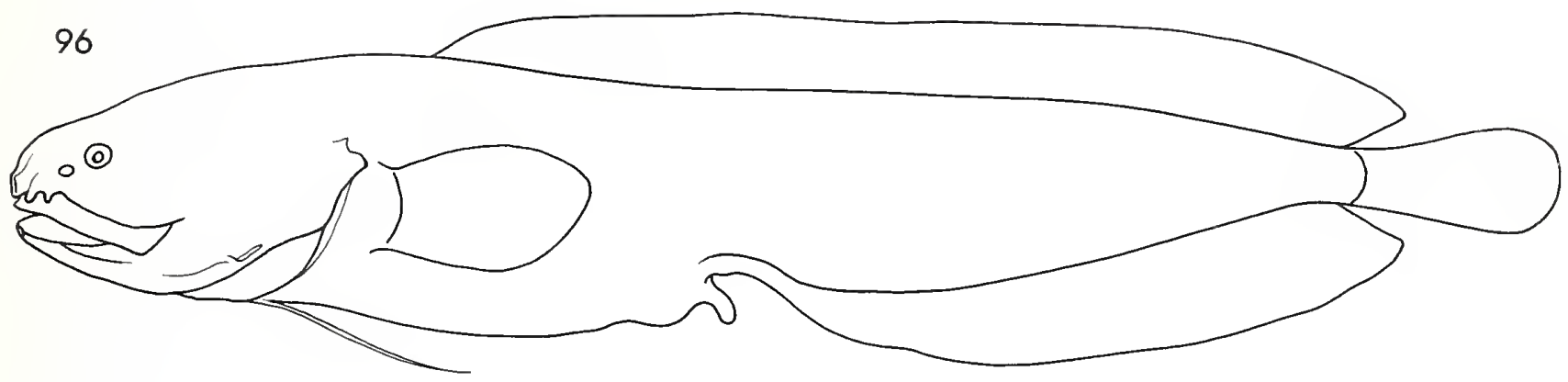

Gunterichthys Dawson (1966:205; type-species by original designation Gunterichthys longipenis Dawson).

Scales on body barely overlapping, absent from head. Eyes minute. Gill membranes free from isthmus. Opercular spine slender and weak. Anterior nostril low, directly above upper lip. Maxillary somewhat expanded posteriorly. Male intromittent organ with one pair of broad pseudoclaspers, each of which contains two ossified supports. Ventral fin rays falling short of vent. Developed rakers on first gill arch 5 to 7 . Branchiostegal rays 8 . Pectoral fin rays 17 to 22 . Caudal fin rays 12 to 15 . Precaudal vertebrae 11 or 12 .

Northeastern Gulf of Mexico in shallow-water mud. The ecology of Gunterichthys has been discussed by Dawson (1971).

A single species. ${ }^{*} G$. longipenis Dawson 1966.

Monothrix Ogilby

(Fig. 97)

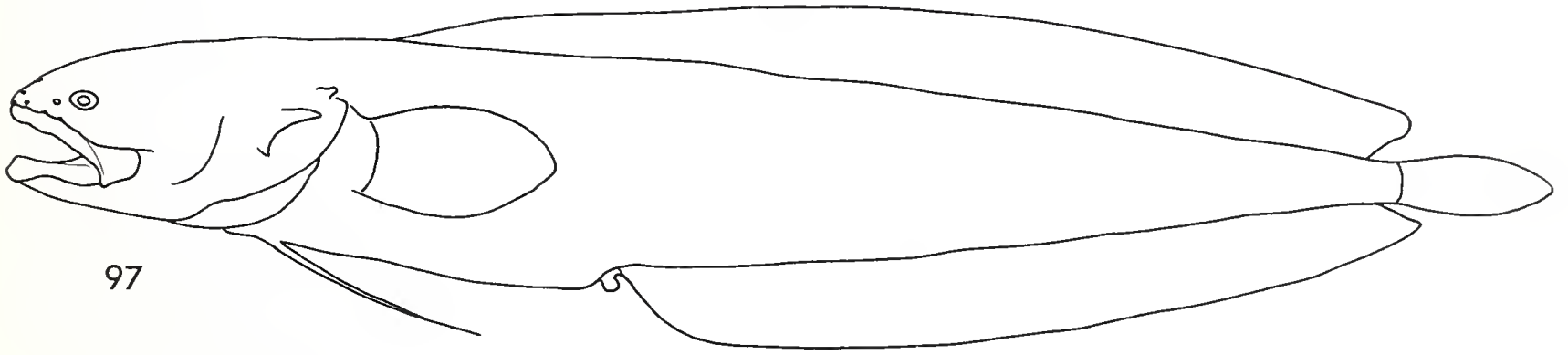


Me nurix Osilby (1897:87; type-species by monotypy Monothrix polylepis Ogilby).

Budy scales imbricate. Head scales absent. Gill membranes free. Opercular spine present. Anterior nostril low, immediately above upper lip. Maxillary vertically expanded posteriorly. Male intromittent organ with a single pair of broad. compressed pseudoclaspers. Branchiostegal rays 7 . Pectoral fin rays 22 . Caudal fin rays 14 . Precaudal vertebrae 1:i or 14. with pointed neural spines.

Australia and? New Zealand; possibly more widely distributed.

Possibly 3 described species: ? M. consobrinus (Hutton 1875), ? ${ }^{*}$ M. mizolepis (Günther 1867), and *M. polylepis Ogilby 1 s97.

\section{Ogilbia Jordan and Evermann}

(Fig. 98)

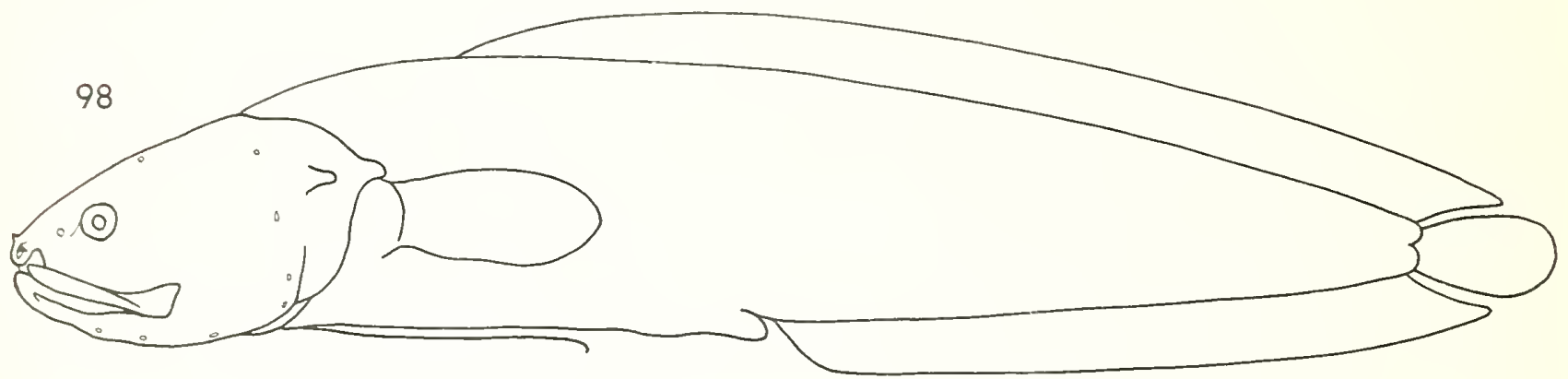

()gilbia Jordan and Evermann in Evermann and Kendall (1898:132; type-species by original designation Ogilbia calorum Evermann and Kendall).

Typhlias Hubbs (1938:132; type-species by original designation Typhlias pearsei Hubbs; preoccupied by Typhlias Bryce 1910 in rotifers).

Tiphliasina Whitley (1951:67; replacement name for Typhlias Hubbs, takes the same type-species).

Capcogilbia Poll and Leleup (1965:466; type-species by monotypy Caecogilbia galapagosensis Poll and Leleup).

Body scales imbricate. Head scales present or absent on cheek, absent from opercle. A sharp spine present on opercle, sometimes buried. Anterior nostril generally placed low on snout. Maxillary expanded vertically at its posterior end. Intromittent organ of male with 2 pseudoclaspers, the largest a compressed, ear-shaped lobe. Branchiostegal rays 7. Precaudal neural spines pointed.

Found in tropical American reefs, in freshwater Yucatan caves, and in brackish water in the Galapagos. Probably occurring in the Indo-Pacific as well.

Six described species may be ascribed to this genus. There are numerous undescribed ones. Reproductive biology has been described by Suarez (1975) and the comparative ecology of 2 Galapagos species has been discussed by van Mol (1967). The genus is being studied by B. Walker. The species are: ${ }^{*} O$. cayorum Evermann and Kendall 1898 , ${ }^{*} O$. deroyi (Poll and van Mol 1966), *O. galapagosensis (Poll and Leleup 1965), *O. pearsei (Hubbs 1938), *O. ventralis (Gill 1863a), and O. verrillii (Garman 1900).

\section{Aphyonidae Jordan and Evermann 1898}

Precaudal vertebrae 26 to 48. Swim bladder absent. Anterior neural spine equal in length to those following. Scales absent, body in freshly caught specimens enveloped in a thick, gelatinous layer. Vertical fins confluent. Eyes poorly developed. Palatine lacking teeth (except in Barathronus). Basibranchial tooth patches absent. Opercular spine weak or ahsent. Ventral fins with a single ray in each or absent. Musculus infracarinalis medialis distinct. Pyloric caeca absent.

The aphyonid genera are notable for a number of neotenic characters, and convergence has been suggested. The problem of how best to classify these curious fishes has been discussed by Nielsen (1969) in a revision of the family.

Two genera among the aphyonids, Aphyonus and Barathronus, have the anterior nostril rather high above the upper lip. a character state that is typical of most oviparous rather than viviparous ophidiiform fishes. It is probable that the early stages of these two genera are pelagic, and although adults are caught in bottom trawls, they also are probably pelagic, although living close to the bottom. Either they never developed low placed nostrils, which would be a neotenic condition for a typical bythitoid, or the nostrils have moved up secondarily, which is a possibility, as the other genera in the family, apparently all of which are deep pelagic, have low placed nostrils. 
1a. I ng rakers on anterior gill arch 24-33. Caudal fin rays 9 or 10. Palatine teeth present

1b. Iong rakers on anterior gill arch 0-14. Caudal fin rays 6-8. Palatine teeth absent

2a. Pectoral fin rays 23-27. Anterior gill arch with a total of 23-26 gill rakers, 6 or 7 relatively long . Nybelinella

2b. Pectoral fin rays 9-19. Anterior gill arch with a total of 8-18 gill rakers, 0-14 relatively long . . . . . . .

3a. I Iong gill rakers 3-14. Precaudal vertebrae 26-33

Aphyonus

3h. long gill rakers 0 . Precaudal vertebrae $39-48 \ldots \ldots . \ldots$

4a. Pectoral peduncle normal. Caudal fin rays 8 . Dorsal fin rays $48-50$. Gill rakers 8 or 9 . . . . . Meteoria

4b. Pectoral peduncle elongate. Caudal fin rays 6 or 7 . Dorsal fin rays 68-104. Gill rakers 11-15 . . . Sciadonus

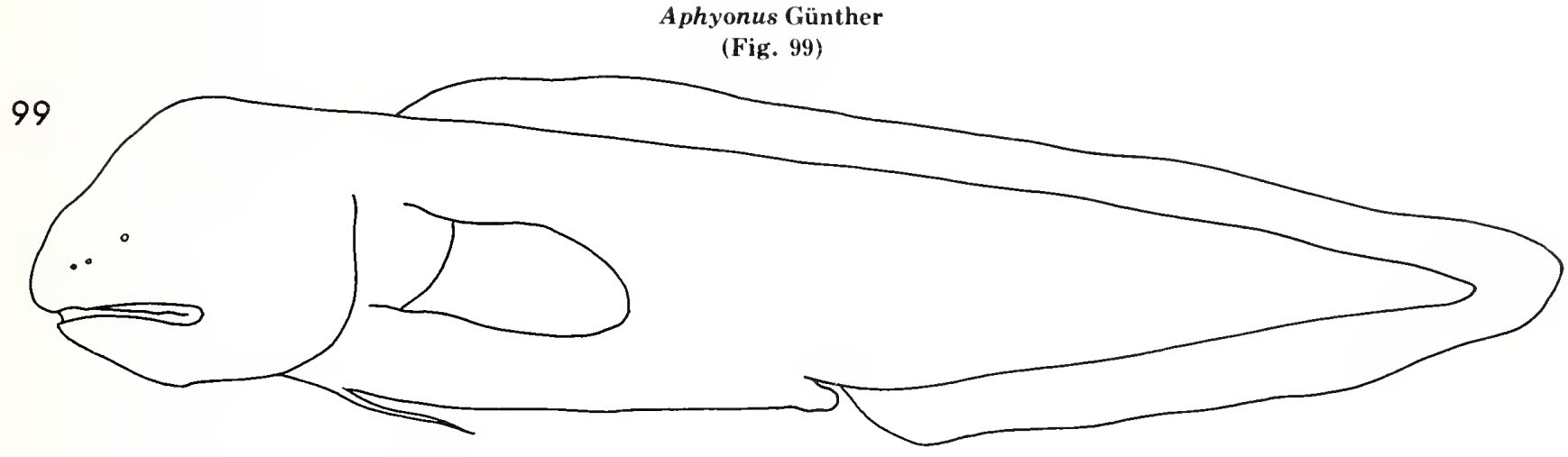

Aphvonus Günther (1878:22; type-species by monotypy Aphyonus gelatinosus Günther).

Mouth almost horizontal. Eyes small or not externally visible. Palatines lacking teeth. Long rakers on anterior gill arch 3 to 14 . Vertebral centra in adults rectangular or nearly so. Ventral fins present. Caudal fin rays 7 or 8 . Pectoral peduncle as long as broad, bearing 13 to 19 rays. Peritoneum dark blue, visible through body wall.

Worldwide at depths ranging from about 900 to $4,360 \mathrm{~m}$ on or near the bottom.

Four species: ${ }^{*} A$. bolini Nielsen $1974,{ }^{*} A$. brevidorsalis Nielsen $1969,{ }^{*} A$. gelatinosus Günther $1878\left({ }^{*} A\right.$. mollis Goode and Bean 1886 is a synonym), and ${ }^{*} A$. rassi Nielsen $1975 \mathrm{~b}$.

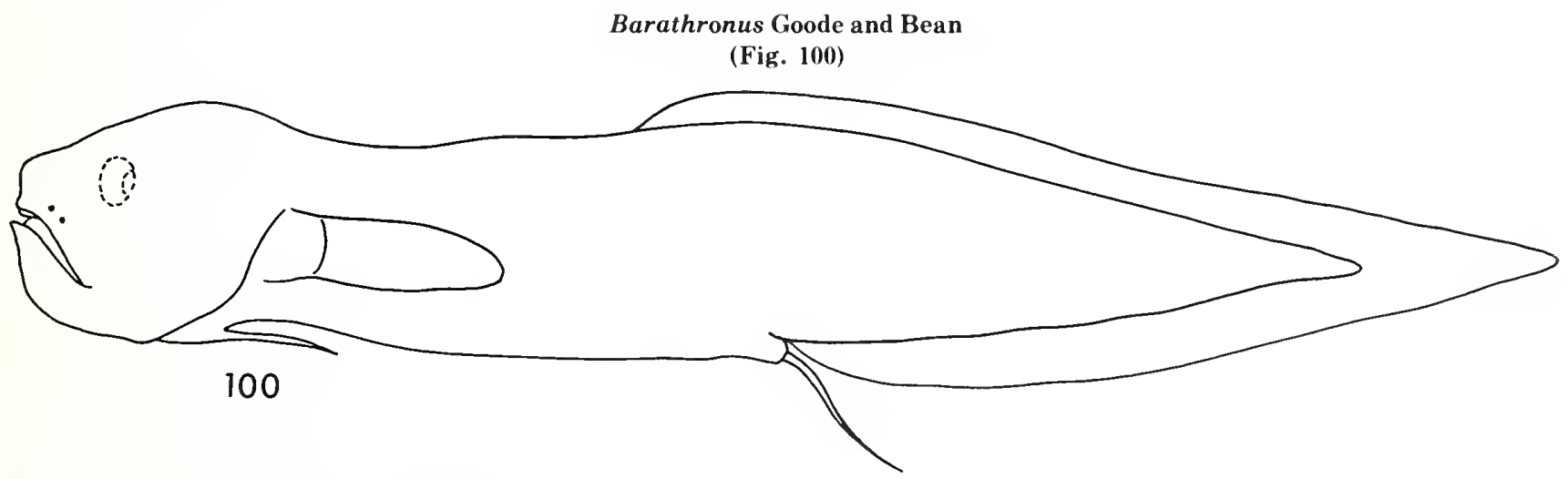

Barathronus Goode and Bean (1886:164; type-species by monotypy Barathronus bicolor Goode and Bean). 
Alexeterion Vaillant (1888:282: type-species by monotypy Alexeterion parfaiti Vaillant).

Mouth oblique. Eves deep-set. Palatine teeth present. Long rakers on anterior gill arch 24 to 33 . Vertebral centra spindle-shaped in adults. Caudal fin rays 9 to 10. Ventral fins present. Pectoral peduncle as long as broad, with 21 to 26 rays

Worldwide at depths ranging from 500 to $3,500 \mathrm{~m}$.

Seven species have been described (another, from the northwest Atlantic, is being described by J. G. Nielsen): ${ }^{*} B$. affinis Brauer 1906. ${ }^{*} B$. bicolor Goode and Bean 1886, ${ }^{*} B$. bruuni Nielsen 1969, ${ }^{*} B$. diaphanus Brauer $1906,{ }^{*} B$. maculatus. Shcherbacher 1976, ${ }^{*}$ B. pacificus Nielsen and Eagle 1974, and ${ }^{*} B$. parfaiti (Vaillant 1888).

Meteoria Nielsen

(Fig. 101)

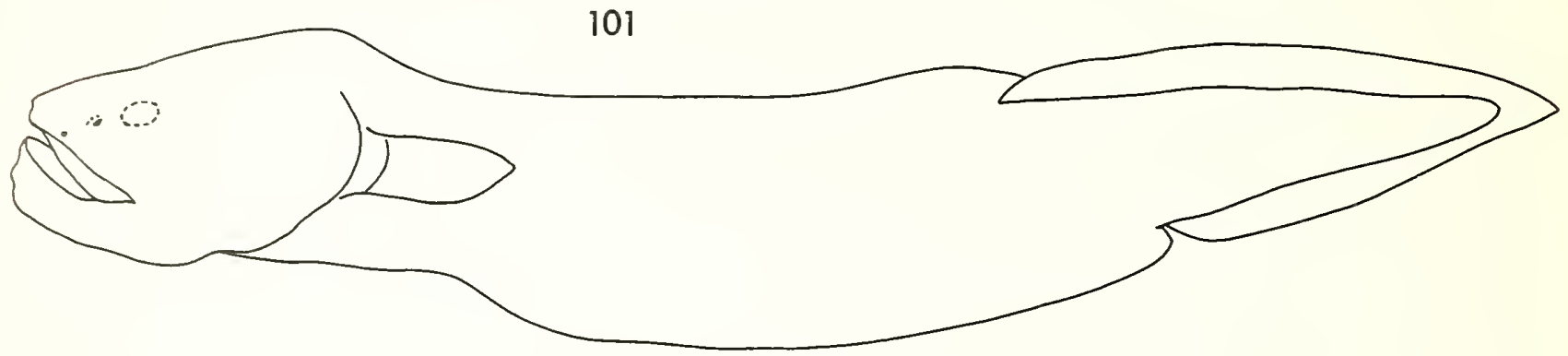

Moterria Nielsen (1969:69; type-species by monotypy Meteoria erythrops Nielsen).

Mouth oblique. Caudal part of body less than one-third of standard length. Eyes minute. Palatines lacking teeth. Anterior gill arch with only 8 or 9 vestigial rakers. Vertebral centra rectangular in adults. Dorsal fin rays 48 to 50 . Anal fin ravis 34 to 40 . Caudal fin ravs 8 . Ventral fins absent. Pectoral peduncle as long as broad, with 13 to 15 rays.

Taken in the eastern North Atlantic at bathypelagic or abyssopelagic depths.

A single species, ${ }^{*} M$. ervthrops Nielsen 1969.

Nybelinella Nielsen

(Fig. 102)

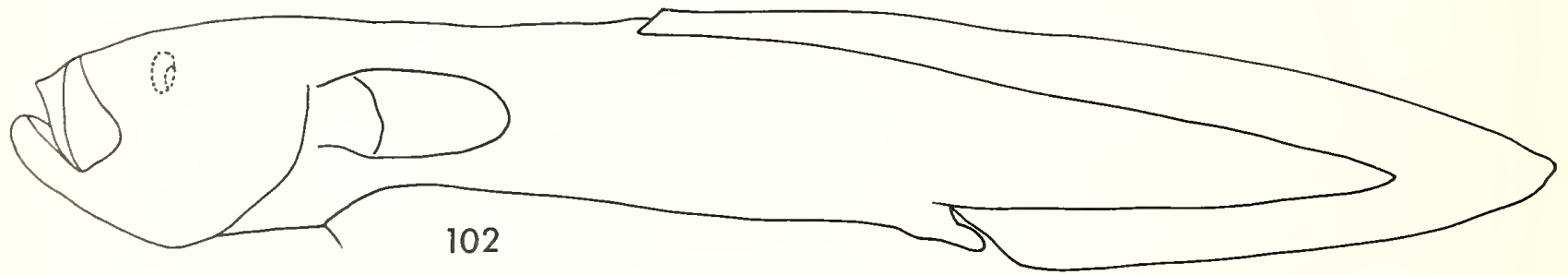

Nybelinia Nielsen (1969:22; type-species by original designation Barathronus erikssoni Nybelin; preoccupied by Nyholinia Poche 1926 in tapeworms).

Nublinella Nielsen (1972:53; replacement name for Nybelinia Nielsen 1969, taking the same type-species).

Mouth oblique. Eyes indistinct. Palatines lacking teeth. Anterior gill arch with 6 or 7 somewhat enlarged rakers, and about 18 short rakers. Vertebral centra rectangular in adults. Ventral fins present. Caudal fin rays 8 . Pectoral peduncle as long as broad, with 23 to 27 rays.

Fastern Atlantic and western Indian Oceans, probably deep pelagic.

Two species: "N. brevidorsalis Shcherbachev 1976, and *N. erikssoni (Nybelin 1957).

\section{Sciadonus Garman}

(Fig. 103)

Sciadronus Garman (1899:171; type-species by monotypy Sciadonus pedicellaris Garman).

Loucrechlamys Zugmayer (1911:11; type-species by monotypy Leucochlamys cryptophthalmus Zugmayer).

Mouth almost horizontal. Eyes small, sometimes not externally visible. Palatines lacking teeth. Anterior gill arch with only 11 to 15 short rakers. Vertebral centra rectangular in adults. Caudal fin rays 6 or 7 . Ventral fin present or absent. Pectoral peduncle considerably longer than broad, with 9 to 14 rays. 


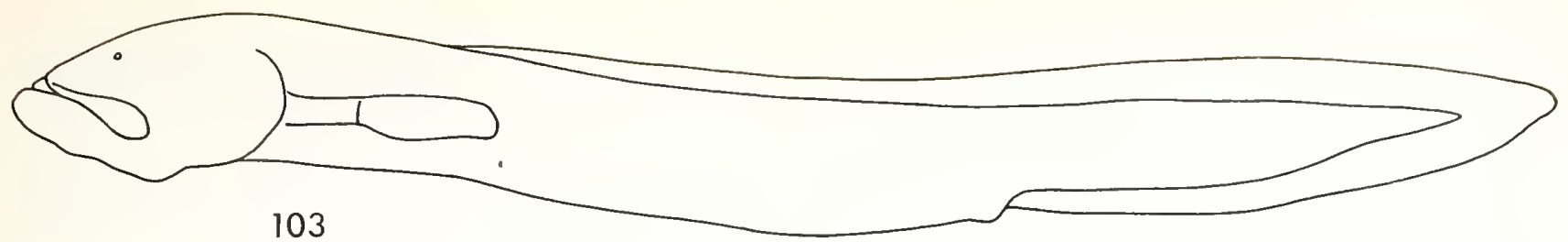

Atlantic and Pacific Oceans, probably deep pelagic.

Sciadonus and Leucochlamys have been considered separate genera based on differences in 3 characters: ventral fins small or absent; anterior nostril tubular or with a low rim; 0 or 2 fangs on vomer. However, a recently examined specimen is intermediate between the two nominal genera. The differences between them are now so insignificant that they cannot be maintained as distinct.

Four valid species: ${ }^{*} S$. cryptophthalmus (Zugmayer 1911), *S. galatheae (Nielsen 1969), ${ }^{*} S$. jonassoni (Nybelin 1957), and ${ }^{*} S$. pedicellaris Garman $1899\left({ }^{*} S\right.$. kullenbergi Nybelin 1957 is a synonym).

\section{ACKNOWLEDGMENTS}

We have received much help from our colleagues in Washington, D.C., and Copenhagen, for which we are very grateful. Additionally, we have benefited from assistance freely given from every corner of the globe, without which it would have been impossible to complete this study. We thank also the custodians of collections in Ann Arbor, Cambridge, Chicago, Gloucester Point, La Jolla, Los Angeles, Miami, New York, Ocean Springs, Palisades, Philadelphia, San Francisco, Woods Hole, Lima, San José, Amsterdam, Bergen, Berlin, Edinburgh, Florence, Funchal, Göteborg, Hamburg, Leiden, Leningrad, Lisbon, London, Monaco, Moscow, Paris, Reykjavik, Tervuren, Vienna, Wormley, Cape Town, Grahamstown, Bangkok, Calcutta, Hong Kong, Kochi, Tel Aviv, Tokyo, Perth, and Sydney.

Special thanks are due C. Richard Robins, who shared with us his knowledge of cusk eels and read the entire manuscript and James E. Böhlke, Bruce B. Collette, and C. E. Dawson, who also read and criticized the entire manuscript. Various sections have been read by $M$. Boeseman, G. Nelson, C. Patterson, and B. Walker all of whom we thank. We note that we have not accepted all of the readers' suggestions and that full responsibility for this paper rests with us alone.

We acknowledge the efforts of Keiko Hiratsuka Moore, who prepared nearly all of the illustrations; George Clipper, who made X-ray photographs of innumerable specimens; Joseph Russo, who prepared many alizarin specimens; Arleen McClain and Virginia Tucker, who typed several drafts of the manuscript; and Gregg Small, who helped compile the index.

\section{LITERATURE CITED}

ALCOCK, A.

1889. Natural history notes from H.M. Indian Marine Survey Steamer 'Investigator,' Commander Alfred Carpenter, R.N., D.S.O., commanding.-No. 13. On the bathybial fishes of the Bay of Bengal and neighboring waters, obtained during the seasons 1885-1889. Ann. Mag. Nat. Hist., Ser. 6, 4:376-399. 1890a. Natural history notes from H.M. Indian Marine Survey Steamer 'Investigator,' Commander R. F. Hoskyn, R.N., commanding.-No. 16. On the bathybial fishes collected in the Bay of Bengal during the season 1889-90. Ann. Mag. Nat. Hist., Ser. 6, 6:197-222.

1890b. Natural history notes from H.M. Indian Marine Survey Steamer 'Investigator,' Commander R. F. Hoskyn, R.N., commanding.-No. 18. On the bathybial fishes of the Arabian Sea, obtained during the season 1889-90. Ann. Mag. Nat. Hist., Ser. $6,6: 295-311$.

1890c. Natural history notes from H.M. Indian Marine Survey Steamer 'Investigator,' Commander R. F. Hoskyn, R.N., commanding.-No. 20. On some undescribed shore-fishes from the Bay of Bengal. Ann. Mag. Nat. Hist., Ser. 6, 6:425-443.

1892. Natural history notes from H.M. Indian Survey Steamer 'Investigator,' Lieut. G. S. Gunn, R.N., commanding.-Ser. II, No. 5. On the bathybial fishes collected during the season of 1891 92. Ann. Mag. Nat. Hist., Ser. 6, 10:345-365.

1893. New species of Lophius, Physiculus, Neobythites, Odontostomus and Congromuraena. J. Asiatic Soc. Bengal 62:177-184.

1894. An account of a recent collection of bathybial fishes from the Bay of Bengal and from the Laccadive Sea. J. Asiatic Soc. Bengal 63:115-137.

1895. Natural history notes from H.M. Indian Survey Steamer 'Investigator,' Commander C. F. Oldham, R.N., commanding.Ser. II, No. 18. On a new species of viviparous fish of the family Ophidiidae. Ann. Mag. Nat. Hist., Ser, 6, 16:144-146.

1896. A supplementary list of the marine fishes of India, with descriptions of two new genera and 8 new species. J. Asiatic Soc. Bengal 65:301-338.

1898. Natural history notes from H.M. Indian Survey Steamer 'Investigator,' Commander T. H. Heming, R.N., commanding.Ser. II, No. 25. A note on the deep-sea fishes, with descriptions of some new genera and species, including another probably viviparous ophidioid. Ann. Mag. Nat. Hist., Ser. 7, 2:136-156.

ARAI, R.

1969. Bythites matsubarai, a new brotulid fish from Japan. [In Engl.] Jap. J. Ichthyol. 16:74-77.

ARAMBOURG, C.

1967. Résultats scientifiques de la mission C. Arambourg en Syrie et en Iran (1938-1939). II. Les poissons Oligocènes de l'Iran. Not. Mém. Moyen-Orient, Mus. Nat. Hist. Nat. Paris 8:11-210.

ARNOLD, D. C.

1956. A systematic revision of the fishes of the teleost family Carapidae (Percomorphi, Blennioidea), with descriptions of two new species. Bull. Br. Mus. (Nat. Hist.) 4:245-307.

AYRES, W. O.

1854. [Description of new fishes from California.] Proc. Calif. Acad. Sci. 1:3-22.

1863. [Descriptions of new species of fishes.] Proc. Calif. Acad. Sci. 2:52-64. 
BARNARD, K. H

19:- A monograph of the marine fishes of South Africa. Part II. Ann. S. Afr. Mus 21:419-1065.

1934. New records and descriptions of two new species of South African marine fishes. Ann. Mag. Nat. Hist., Ser. 10, 13:228-235.

BLEEKER, P

1855. Bijdrage tot de kennis der ichthyologische fauna van de Batoe Eilanden. Nat. Tijdschr. Neder.-Indië 8:305-328.

1858. Vierde bijdrage tot de kennis der ichthyologische fauna van Japan. Act. Soc. Sci. Indo-Neerlandicae 3:1-46.

BLOCH. M. E., and J. G. SCHNEIDER.

1801. Systema ichthyologiae iconobus ex illustratum. Berlin, $584 \mathrm{p}$.

BÖLKE, J. E

1955. The brotulid fish genus Petrotyx from the Great Bahama Bank. Acad. Nat. Sci. Phila. Not. Nat. 273, 6 p.

1957. A new shallow-water brotulid fish from the Great Bahama Bank. Acad. Nat. Sci. Phila. Not. Nat. 295, 8 p.

BOHLKE, J. E., and D. M. COHEN

1966. A new shallow-water ophidioid fish from the tropical West Atlantic. Acad. Nat. Sci. Phila. Not. Nat. 396, 7 p.

BOHLKE, J. E., and C. R. ROBINS.

1959. Studies on fishes of the family Ophidiidae.-II. Three new species from the Bahamas. Proc. Acad. Nat. Sci. Phila. 111:3752.

BOESEMAN, M.

1960. Notes on marine fishes from the Netherlands Antilles, with the description of a new species, Eutyx tumidifrons (Brotulidae). Zool. Meded. (Leiden) 37:11-16.

BOUGIS, P., and M. RUTVO.

1954. Recherches sur le poisson de profondeur Benthocometes robustus (Goode et Bean) (= Pteridium armatum, Doederlein) (Brotulidae). Vie Milieu, suppl. 3:155-209.

BRAUER, A.

1906. Die Tiefsee-Fische. 1. Systematischer Teil. Wiss. Ergeb. Dtsch. Tiefsee-Exped., bd. 15, lief. 1, p. 1-420.

BREDER, C. M., Jr.

1936. Heterosomata to Pediculati from Panama to Lower California. Bull. Bingham Oceanogr. Collect, Yale Univ. 2, art. 3, 56 p

BYRNE, L. W

1906. A new species of Pteridium (Scopoli) from the North-east Atlantic. Ann. Mag. Nat. Hist., Ser. 7, 18:448-450.

CHAN, W. L.

1966. A new genus and species of deep-sea brotulid from the South China Sea. [In Engl.] Jap. J. Ichthyol. 14:4-8,

CHINA, W. E

1962. Request for a ruling that Jordan and Evermann did not designate type-species validly in either their work dated $1896-1900$ or that of 1896 (Pisces). Bull. Zool. Nomencl. 19:220-229.

COHEN, D. M.

1961. A new genus and species of deepwater ophidioid fish from the Gulf of Mexico. Copeia 1961:288-292.

1963. A new genus and species of bathypelagic ophidioid fish from the western North Atlantic. Breviora 196, 8 p.

1964a. A review of the ophidioid fish genus Luciobrotula with the description of a new species from the western North Atlantic. Bull. Mar. Sci. 14:387-398.

1964b. A review of the ophidioid fish genus Oligopus with the description of a new species from West Africa. Proc. U.S. Natl. Mus. 116:1-22.

1966. A new tribe and a new species of ophidioid fish. Proc. Biol. Soc. Wash. 79:183-204.

1973. Viviparous ophidioid fish genus Calamopteryx: new species from western Atlantic and Galapagos. Proc. Biol. Soc. Wash. 86: $339-350$.

1974a. A review of the pelagic ophidioid fish genus Brotulataenia with descriptions of two new species. Zool. J. Linn. Soc. 55:119. 149.

1974b. The ophidioid fish genus Luciobrotula in the Hawaiian Islands. Pac. Sci. 28:109-110.

COHEN, D. M., and J. G. NIELSEN.

1972. A review of the viviparous ophidioid fishes of the genus Saccogaster. Proc. Biol. Soc. Wash. 85:445-468.
COHEN, D. M., and C. R. ROBINS.

1970. A new ophidioid fish (genus Lucifuga) from a limestone sink, New Providence Island, Bahamas. Proc. Biol. Soc. Wash. 83:133144.

COHEN, D. M., and J. P. WOURMS.

1976. Microbrotula randalli, a new viviparous ophidioid fish from Samoa and New Hebrides, whose embryos bear trophotaeniae. Proc. Biol. Soc. Wash. 89:81-98.

COURTENAY, W. R., Jr.

1971. Sexual dimorphism of the sound producing mechanism of the striped cusk-eel, Rissola marginata (Pisces: Ophidiidae). Copeia 1971:259-268.

COURTENAY, W. R., Jr., and F. A. McKITTRICK.

1970. Sound-producing mechanisms in carapid fishes, with notes on phylogenetic implications. Mar. Biol. (Berl.) 7:131-137.

CUVIER, G. L.

1829. Le règne animal distribué d'apres son organisation, pour servir de base à l'histoire naturelle des animaux, et d'introduction à l'anatomie comparée. $2 \mathrm{~d}$ ed., vol. 2, Paris, $406 \mathrm{p}$.

DANIL'CHENKO, P. G.

1968. Fishes of the upper Paleocene of Turkmenia. In Topics in the phylogeny and taxonomy of fossil fishes and Agnatha, p. 113156. Akad. Nauk SSSR. (Transl. from Russ.; available Clearinghouse Fed. Sci. Tech. Inf., Springfield, Va., as TT 71-50017.)

DAWSON, C. E.

1366. Gunterichthys longipenis, a new genus and species of ophidioid fish from the northern Gulf of Mexico. Proc. Biol. Soc Wash. 79:205-214.

1971. Supplemental observations on Gunterichthys longipenis, a northern Gulf of Mexico brotulid fish. Copeia 1971:164-167.

DAY, F.

1888. Fishes of India. Suppl. Lond., p. 779-816.

DeBEAUFORT, L. F., and W. M. CHAPMAN.

1951. The fishes of the Indo-Australian Archipelago. Vol. 9. E. J. Brill, Leiden, 484 p.

De KAY, J. E.

1842. Zoology of New York, or the New-York fauna. Vol. 1, part 4, Fishes. W. \& A. White \& J. Visscher, N.Y., 404 p.

DÓDERLEIN, P.

1886. Descrizione zoologico-zootomica di una novella specie di pesce del mar di Sicilia, Pteridium armatum Död. Naturalista Sicil. 7:105-109, 129-133.

DOLLO, M. L.

1906. Neobythites brucei, poisson abyssal nouveau recueilli par l'Expédition Antarctique Nationale Ecossaise. Note préliminaire. Proc. R. Soc. Edinb. 26:172-181.

EIGENMANN, C. H.

1909. Cave vertebrates of America. Carnegie Inst. Wash. Publ $104,241 \mathrm{p}$.

EVERMANN, B. W., and W. C. KENDALL.

1898. Descriptions of new or little-known genera and species of fishes from the United States. Bull. U.S. Fish Comm. for 1897, 17:125-133.

FILIPPI, F. de, and A. KÖLLIKER.

1856. Ueber die schwimmblase des Oligopus ater Risso. Z. Wiss. Zool. 7:170-171.

FOLLETT, W. I.

1970. Benthic fishes cast ashore by giant waves near Point Joe, Monterey County, California. Proc. Calif. Acad. Sci., Ser. 4, 37:473-488.

FOLLET'T, W. I., and D. M. COHEN.

1958. Request for a ruling as to the species to be accepted as the type species of the nominal genus "Bathylagus" Gunther (A.C.L.G.), 1878 (Class Pisces). Bull. Zool. Nomencl. 16:73-78.

FOWLER, H. W.

1900. Contributions to the ichthyology of the tropical Pacific. Proc. Acad. Nat. Sci. Phila. 1900:493-528.

1925. New taxonomic names of West African marine fishes. Am. Mus. Novit. $162,5 \mathrm{p}$.

1934. Fishes obtained by Mr. H. W. Bell-Marley chiefly in Natal and Zululand in 1929 to 1932. Proc. Acad. Nat. Sci. Phila. 86: 405-514. 
1941. Notes on Florida fishes with descriptions of seven new species. Proc. Acad. Nat. Sci. Phila. 93:81-106.

1946. A collection of fishes obtained in the Riu Kiu Islands by Captain Ernest R. Tinkham A.U.S. Proc. Acad. Nat. Sci. Phila. 98: 123-218.

1948. Description of a new cusk (Otophidium grayi) from the east coast of Florida. Acad. Nat. Sci. Phila. Not. Nat. 204, 4 p.

FOWLER, H. W., and H. STEINITZ.

1956. Fishes from Cyprus, Iran, Iraq, Israel and Oman. Bull. Res. Counc. Isr. 5B:260-292.

FRASER, T. H.

1972. Some thoughts about the teleostean fish concept-the Paracanthopterygii. Jap. J. Ichthyol. 19:232-242.

FREIHOFER, W. C.

1963. Patterns of the ramus lateralis accessorius and their systematic significance in teleostean fishes. Stanford Ichthyol. Bull. 8: $81-189$.

1970. Some nerve patterns and their systematic significance in paracanthopterygian, salmoniform, gobioid, and apogonid fishes. Proc. Calif. Acad. Sci. 38:215-264.

GARMAN, S.

1899. Reports on an exploration off the west coasts of Mexico, Central and South America, and off the Galapagos Islands, in charge of Alexander Agassiz, by the U.S. Fish Commission steamer "Albatross," during 1891, Lieut. Commander Z. L. Tanner, U.S.N. commanding. XXVT. The fishes. Mem. Mus. Comp. Zool. Harvard Coll. 24, $431 \mathrm{p}$.

1900. Additions to the ichthyological fauna of the Bermudas, from the collections of the Yale expedition of 1898 . Trans! Conn. Acad. 10:510-512.

GIGLIOLI, E. H.

1883. Intorno a due nuovi pesci dal golfo di Napoli. Zool Anz. 6:397-400.

GILBERT, C. H.

1890. Preliminary report on the fishes collected by the steamer Albatross on the Pacific coast of North America during the year 1889 , with descriptions of twelve new genera and ninety-two new species. Proc. U.S. Natl. Mus. 13:49-126.

1891. Descriptions of thirty-four new species of fishes collected in 1888 and 1889 , principally among the Santa Barbara Islands and in the Gulf of California. Proc. U.S. Natl. Mus. 14:539-566.

1905. The deep-sea fishes. In D. S. Jordan and B. W, Evermann, The aquatic resources of the Hawaiian Islands, part II, sect. II, p. 577-713. Bull. U.S. Fish Comm. 23.

GILCHRIST, J. D. F

1903. Descriptions of new South African fishes. Mar. Invest. S. Afr. 2:203-211.

GILCHRIST, J. D. F., and C. von BONDE.

1924. Deep-sea fishes procured by the S. S. "Pickle" (Part II). Union S. Afr. Fish. Mar. Biol. Surv. 1922, Spec. Rep. VII, 24 p.

GILL, T. N.

1861. Catalogue of the fishes of the eastern coast of North America, from Greenland to Georgia. Proc. Acad. Nat. Sci. Phila. 1861, Suppl., 63 p.

1861b. Notes on some genera of fishes of the western coast of North America. Proc. Acad. Nat. Sci. Phila. 1861:164-168.

1862. Notice of a collection of the fishes of California, presented to the Smithsonian Institution, by Mr. Samuel Hubbard. Proc. Acad. Nat. Sci. Phila. 1861:274-282.

1863a. Descriptions of the genera of gadoid and brotuloid fishes of western North America. Proc. Acad. Nat. Sci. Phila, 1863:242254.

1863b. Description of a new generic type of ophidioids. Proc. Acad. Nat. Sci. Phila. 1863:209-211.

1884. Diagnosis of new genera and species of deep-sea fish-like vertebrates. Proc. U.S. Natl. Mus. 6:253-260.

1895. The genus Leptophidium. Am. Nat. 29:167-168.

GIRARD, C.

1858. Fishes. In Reports of explorations and surveys for a railroad route from the Mississippi River to the Pacific Ocean. Vol. 10, part IV, 400 p. War Dep., Wash., D.C.

GOODE, G. B., and T. H. BEAN.

1883. Reports on the results of dredging under the supervision of
Alexander Agassiz, on the east coast of the United States, during the summer of 1880 , by the U.S. Coast Survey steamer "Blake," Commander J. R. Bartlett, U.S.N., commanding. XIX. - Report on the fishes. Bull. Mus. Comp. Zool. Harvard Coll. 10:183-226.

1885. Description of Leptophidium cervinum and L. marmoratum, new fishes from deep water off the Atlantic and Gillf coasts. Proc. U.S. Natl. Mus. 8:422-424.

1886. Description of thirteen species and two genera of fishes from the "Blake" collection. Bull. Mus. Comp. Zool. Harvard Coll. 12:153-170.

1896 (1895). Oceanic ichthyology. U.S. Natl. Mus. Spec. Bull. 2, $553 \mathrm{p}$.

GOSLINE, W. A

1953. Hawaiian shallow-water fishes of the family Brotulidae, with the description of a new genus and notes on brotulid anatomy. Copeia 1953:215-225.

1954. Fishes killed by the 1950 eruption of Mauna Loa. II. Brotulidae. Pac. Sci. 8:68-83.

1960. Hawaiian lava-flow fishes, part IV Snyderidia canina Gilbert, with notes on the osteology of ophidioid families. Pac. Sci. 14: $373-381$.

1968. The suborders of perciform fishes. Proc. U.S. Natl. Mus. 124:1-78

GREY, M.

1951. Additions to the fish fauna of Bermuda, with the description of Grammonus mowbrayi, a new brotulid. Copeia 1951:153-161.

1958. Descriptions of abyssal benthic fishes from the Gulf of Mexico. Fieldiana: Zool. 39:149-183.

GUICHENOT, A

1848. Peces de Chile. In Historia fisica y politica de Chile by C. Gay, Zoologia, t. 2:137-370. Paris and Santiago.

GUNTHER, A.

1862. Catalogue of the fishes in the British Museum. Vol. 4. Br. Mus., Lond., 534 p.

1867. Additions to the knowledge of Australian reptiles and fishes. Ann. Mag. Nat. Hist., Ser. 3, 20:45-68.

1877. Preliminary notes on new fishes collected in Japan during the expedition of H.M.S. 'Challenger.' Ann. Mag. Nat. Hist., Ser. 4, 20:433-446.

1878. Preliminary notices of deep-sea fishes collected during the voyage of H.M.S. Challenger. Ann. Mag. Nat. Hist., Ser. 5, 2:17$28,179-187,248-251$.

1880. Report on the shore fishes procured during the voyage of H.M.S. Challenger in the years 1873-1876. Zoology of the Challenger Expedition. Ser. V, vol. 1, part 6, $82 \mathrm{p}$.

1887. Report on the deep-sea fishes collected by H.M.S. Challenger during the years 1873-76. Zoology of the Challenger Expedition. Ser. V, vol. 22 , part 57,335 p.

HARBISON, G. R., K. L. SMITH, Jr., and R. H. BACKUS.

1973. Stygiomedusa fabulosa from the North Atlantic: Its taxonomy, with a note on its natural history. J. Mar. Biol. Assoc. U.K. 53:615-617.

HARRY, R. R.

1951. A new cusk-eel of the genus Ophidion from California with notes on the genus. Stanford Ichthyol. Bull. 4:30-35.

HELLER, E., and R. E. SNODGRASS.

1903. Hopkins-Stanford Galapagos Expedition-XV. New fishes. Proc. Wash. Acad. Sci. 5:189-229.

HERRE, A. W., and E. S. HERALD.

1951. Noteworthy additions to the Philippine fish fauna with descriptions of a new genus and species. Philipp. J. Sci. 79:309-339.

HILDEBRAND, S. F., and O. BARTON.

1949. A collection of fishes from Talara, Perú. Smithson. Misc. Collect. 111(10), 36 p.

HOWELL RIVERO, L.

1934. Nuevo género de peces para Cuba. Mem. Soc. Cubana Hist. Nat. 8:69-72.

HUBBS, C. L

1916. Notes on the marine fishes of California. Univ. Calif. Publ. Zool. 16:153-169.

1938. Fishes from the caves of Yucatan. Carnegie Inst. Wash. Publ. 491:261-295.

1944. Species of the circumtropical fish genus Brotula. Copeia 1944:162-178. 
HITTON. F. II

15i5. Contributions to the ichthyology of New Zealand. Trans.

X.Z. Inst. 8:209-218.

TORDAI. D. S.

18:- A catalogue of the tishes known to inhabit the waters of

North America. north of the tropic of cancer, with notes on the spe-

cies discovered in 1883 and 1884. Rep. U.S. Fish Comm. for 1885. $13: 789-973$.

1919. The genera of fishes, part II. Stanford Univ. Publ., Univ. Ser. 36: $367-284$

1920. The genera of fishes, part IV. Stanford Univ. Publ., Univ. ser. $43: 411-576$

JORDA I. D. $\Omega$, and C. H. BOLLMAN

1890. Descriptions of new species of fishes collected at the Galapagos Islands and along the coast of the United States of Colombia, 1887-88. Proc. U.S. Natl. Mus. 12:149-183.

JORDAN, D. S., and B. WV. EVERMANN.

1896. A check-list of the fishes and fish-like vertebrates of North and Middle America. Rep. Comm. U.S. Fish Comm. for 1895 590 p.

1898. The fishes of North and Middle America. U.S. Natl. Mus. Bull. 47, part 3:2183-3136

1903. Descriptions of new genera and species of fishes from the Hawaiian Islands. Bull. U.S. Fish Comm. for 1902, 22:161-208

JORDA.N. D. S., and H. W. FOWLER

1902. A review of the ophidioid fishes of Japan. Proc. U.S. Natl. Mus. 25:743-766.

JORDAN, D. S., and C. H. GILBERT

1882. Note on fishes observed about Pensacola, Florida, and Galveston. Texas, with description of new species. Proc. U.S. Natl. Mus. 5:241-307

1883. Description of two new species of fishes (Aprion ariommus and Ophidium beani) from Pensacola, Florida. Proc. U.S. Natl. Mus. 6:142-144

JORDAN, D. S., and C. L. HUBBS.

1925. Record of fishes obtained by David Starr Jordan in Japan, 1922. Mem. Carnegie Mus. 10:93-346.

JORDAN, D. S., and J. O. SNYDER.

1901. List of fishes collected in 1883 and 1885 by Pierre Louis Jouy and preserved in the United States National Museum, with descriptions of six new species. Proc. U.S. Natl. Mus. 23:739-769.

JORDAN, D. S., and W. F. THOMPSON

1914. Record of the fishes obtained in Japan in 1911. Mem. Carnegie Mus. 6:205-313.

KAMOHARA, T.

1936. Supplementary notes on the fishes collected in the vicinity of Kôti (IX). Zool. Mag. 48:306-311.

1938. On the offshore bottom-fishes of Prov. Tosa, Shikoku, Japan. Maruzen, Tokyo, $86 \mathrm{p}$.

KAUP, ,

1858. Uebersicht der Familie Gadidae. Arch. Naturgesch. 24:8593.

KOEFOED, E

1927. Fishes from the sea-bottom. Rep. Sci. Results "Michael Sars" North Atl. Deep-Sea Exped. 1910, 4(1), 147 p.

LEE, R. S.

1974. Thalassobathia nelsoni, a new species of bathypelagic ophidioid fish from Chilean waters. Copeia 1974:629-632.

LINNAEUS, C.

1758. Systema naturae. Stockholm, $823 \mathrm{p}$

LLOYD, R. E

1909. A description of the deep-sea fish caught by the R.I.M.S. ship

"Investigator" since the year 1900, with supposed evidence of mutation in Malthopsis. Mem. Indian Mus. 2:139-180.

MARSHALL, N. B., and D. M. COHEN

1973. Order Anacanthini (Gadiformes). Characters and synopsis of families. Mem. Sears Found. Mar. Res. 1(6):479-495.

MATSUPARA, K.

1943. Ichthyological annotations from the depth of the Sea of Japan, I.VII. J. Sigenkagaku Kenkyusyo 1:37-81.

MAUL, G. F

1975. The fishes taken in bottom trawls by R. V. "Meteor" during the 1967 Seamounts Cruises in the Northeast Atlantic. "Meteor" Forschungsergebnisse, D, 22:1-69.

MAYER, R. F., and T. T. NALBANT.

1972. Additional species of fishes in the fauna of Peru Trench.

Results of the 11th cruise of R/V "Anton Bruun", 1965. Rev. Roum. Biol. Ser. Zool. 17:159-165.

McALLISTER, D. E.

1968. Evolution of branchiostegals and classification of teleostome fishes. Natl. Mus. Can., Bull. 221, 239 p.

McCANN, C

1972. Additions to the deep-sea fishes of New Zealand. N.Z. J. Mar. Freshwater Res. 6:619-640.

McCULLOCH, A. R., and E. R. WAITE

1918. Some new and little-known fishes from South Australia. Rec. S. Aust. Mus. Adelaide 1:39-78.

MEAD, G. W., E. BERTELSEN, and D. M. COHEN.

1964. Reproduction among deep-sea fishes. Deep-Sea Res. 11: 569-596.

MEEK, S. E., and S. F. HILDEBRAND.

1928. The marine fishes of Panama. Field Mus. Nat. Hist., publ. 249, Zool. Ser. 15, part 3:709-1045.

MENON, A. G. K., and K. V. RAMA RAO.

1970. Systematic position of Brotula jerdoni Day, a shallow-water brotulid fish from the Bay of Bengal. J. Zool. Soc. India 22:47-49.

MENNI, R. C., and H. L. LOPEZ.

1974. Presencia en la Argentina de Raneya fluminensis (Miranda Ribeiro, 1903) Robins, 1961. Neotropica 20:1-6.

MEYER-ROCHOW, V. B.

1970. Cataetyx memoriabilis $\mathrm{n}$. sp., - ein neuer Tiefsee-Ophidiide aus dem südöstlichen Atlantic. Abh. Verh. Naturwiss. Ver. Hamburg (NF) 14:37-53.

MÚLLER, J.

1845. Untersuchungen über die Eingeweide der Fische, Schluss der verleichenden Anatomie der Myxinoiden. Abh. Preuss. Akad. Wiss. 1843:109-170.

NICHOLS, J. T., and C. M. BREDER.

1922. Otophidium welshi, a new cusk eel, with notes on two others from the Gulf of Mexico. Proc. Biol. Soc. Wash. 35:13-16.

NIELSEN, J. G

1966. On the genera Acanthonus and Typhlonus (Pisces, Brotulidae). Galathea Rep. 8:33-47.

1969. Systematics and biology of the Aphyonidae (Pisces, Ophidioidea). Galathea Rep. 10:7-88.

1971. Redescription of the genus Selachophidium (Pisces, Brotulidae) with two new species. Arch. Fischereiwiss. 22:17-33.

1972. Rare Northeast Atlantic aphyonid fishes (Ophidioidei). "Meteor" Forschungsergebnisse, D, 12:52-55.

1974. Aphyonus bolini, a new deep sea fish from the South China Sea (Pisces, Ophidioidei, Aphyonidae). Steenstrupia, Zool. Mus. Univ. Copenhagen 3:179-182.

1975a. A review of the oviparous ophidioid fishes of the genus Leucicorus, with description of a new Atlantic species. Tr. Inst. Okeanol. Akad. Nauk. SSSR 101:106-123. (NMFS Syst. Lab. Transl. 74.)

1975b. List of ophidioid fishes from the 14th cruise of the "Akademik Kurchatov" with a new species of Aphyonus. Tr. Inst. Okeanol. Akad. Nauk. SSSR 100:348-353. (NMFS Syst. Lab. Transl. 72.)

1977. The deepest living fish Abyssobrotula galatheae a new genus and species of oviparous ophidioids (Pisces, Brotulidae). Galathea Rep. 14:41-48.

NIELSEN, J. G., and G. BINI.

1972. A Mediterranean record of the West Atlantic fish Lepophidium cervinum (Ophidiidae). Copeia 1972:597-599.

NIELSEN, J. G., and D. M. COHEN.

1968. Redescription of Bellottia apoda Giglioli, 1883 (Pisces, Ophidioidea). Proc. Linn. Soc. Lond. 179:99-106.

1973. A review of the viviparous ophidioid fishes of the genera Bythites Reinhardt and Abythites new (Pisces, Ophidioidei). Steenstrupia, Zool. Mus. Univ. Copenhagen 3:71-88.

NIELSEN, J. G., and R. J. EAGLE.

1974. Descriptions of a new species of Barathronus (Pisces, Aphy- 
onidae) and four specimens of Sciadonus sp. from the eastern Pacific. J. Fish. Res. Board Can. 31:1067-1072.

NIELSEN, J. G., A. JESPERSEN, and O. MUNK.

1968. Spermatophores in Ophidioidea (Pisces, Percomorphi). Galathea Rep. 9:239-254.

NIELSEN, J. G., and O. NYBELIN

1963. Brotulidae (Pisces, Percomorpha) from tropical West Africa. Atl. Rep. 7:195-213.

NORMAN, J.R.

1939. Fishes. In The John Murray Expedition 1933-34 scientific reports VII, 116 p. Br. Mus. (Nat. Hist.), Lond.

1966. A draft synopsis of the orders, families and genera of Recent fishes and fish-like vertebrates. Br. Mus. (Nat. Hist.), Lond., $649 \mathrm{p}$.

NYBELIN, 0

1954. Sur la distribution gèographique et bathymétrique des brotulides trouvés au-dessous de 2,000 mètres de profondeur. In On the distribution and origin of the deep sea bottom fauna. Int. Union Biol. Sci. ser. B, no. 16, 88 p.

1957. Deep-sea bottom-fishes. Rep. Swedish Deep-Sea Exped. 1947-1948. Vol. 2, no. 20, Zoology:247-345.

NYBELIN, O., and M. POLL.

1958. Brotulidae des cotes africaines de l'Atlantique Sud avec description d'une espece nouvelle de Lamprogrammus. Inst. R. Sci. Nat. Belg. Bull. 34(19), 7 p.

OGILBY, J. D.

1896. Descriptions of two new genera and species of Australian fishes. Proc. Linn. Soc. N.S.W. 21:136-142.

1897. New genera and species of Australian fishes. Proc. Linn. Soc. N.S.W. 22:62-95

1898. Additions to the fauna of Lord Howe Island. Proc. Linn. Soc. N.S.W. $22: 136-142$.

OSORIO, B

1917. Nota sôbre algunas especes de peixes que vivem no Atlantico ocidental. Arq. Univ. Lisboa 4:103-131

PARR, A. E.

1933. Deepsea Berycomorphi and Percomorphi from the waters around the Bahama and Bermuda Islands. Bull. Bingham Oceanogr. Collect., Yale Univ. 3, art, 6, 51 p.

1934. Report on experimental use of a triangular trawl for bathypelagic collecting with an account of the fishes obtained and a revision of the family Cetomimidae. Bull. Bingham Oceanogr. Collect., Yale Univ. 4, art. 6, 59 p.

PHILIPPI, R. A.

1857. Ueber einige Chilenische Vogel and Fische. Arch. Naturgesch. 23:262-272.

POEY, F

1851-61. Memorias sobre la Historia Natural de la Isla de Cuba, vols. 1, 2, 905 p. Havana.

POLL. M., and N. LELEUP.

1965. Un poisson aveugle nouveau de la famille des Brotulidae provenant des īles Galapagos. Bull. Acad. R. Belg. cl. Sci. Ser. 5 , $51: 464-474$

POLL, M., and J. J. VAN MOL.

1966. Au sujet d'une espèce inconnue de Brotulidae littoral des íles Galapagos, apparentée à l'espèce aveugle Caecogilbia galapagosensis Poll et Leleup. Bull. Acad. R. Belg. cl. Sci. Ser. 5, 52:1444-1461.

PRIEM, F

1908. Poissons fossiles de Perse. Ministère de l'Instruction Publique et des Beaux-Arts. Dèlégation en Perse. Ann. d'Hist. Nat. 1, Palèontologie, Paris, 25 p.

PUTNAM, F. W

1874. Notes on the Ophidiidae and Fierasferidae. Proc. Boston Soc. Nat. Hist. 16:339-348.

RADCLIFFE, $\boldsymbol{L}$.

1913. Descriptions of seven new genera and thirty-one new species of fishes of the families Brotulidae and Carapidae from the Philippine Islands and the Dutch East Indies. Proc. U.S. Natl. Mus. 44:135-176.

RAFINESQUE, C. S.

1810. Indice d'Ittiologia Siciliana. Messina, $70 \mathrm{p}$.
RAO, V. V.

1972. A redescription of Sirembo jerdoni (Day): (Pisces: Brotulidae). J. Bombay Nat. Hist. Soc. 67:114-117.

RASS, T. C.

1955. Deep-sea fishes of the Kurile-Kamchatka Trench. Tr. Inst. Okeanol. Akad. Nauk. SSSR 12:328-339. (George Vanderbilt Found. transl.)

REGAN, C. T

1903. Description of a new fish of the genus Genypterus, with notes on the allied species. Ann. Mag. Nat. Hist., Ser. 7, 11:599-600.

1914. Diagnoses of new marine fishes collected by the British Antarctic ('Terra Nova') Expedition. Ann. Mag. Nat. Hist., Ser. 8, 13:11-17.

1921. New fishes from deep water off the coast of Natal. Ann. Mag. Nat. Hist., Ser. 9, 7:412-420.

REINHARDT, J

1835. "Preliminary report" Overs, K. Danske Vidensk. Selsk. Forh. 1834-35:1-40.

1837. Ichthyologiske bidrag til den Grönlandske Fauna. 1. Copenhagen, $122 \mathrm{p}$.

RIBEIRO, A. de M.

1903. Pescas do Annie. A. Lavoura, Bol. Soc. Nac. Agric. 4-7:157.

RISSO, A

1810. Ichthyologie de Nice ou histoire naturelle des poissons du départment des Alpes Maritimes. F. Schoell, Paris, 388 p.

1826. Histoire naturelle des poissons de la Méditerranée qui fréquentent les cotes des Alpes Maritimes, et qui vivent dans le Golfe de Nice. In Histoire naturelle des principales productions de l'Europe Méridionale, 3:97-480. F. G. Levrault, Paris.

ROBERTSON, D. A

1975. Planktonic stages of the teleost family Carapidae in eastern New Zealand waters. N.Z. J. Mar. Freshwater Res, 9:403-409.

ROBINS, C. R

1958. Studies on fishes of the family Ophidiidae.-I. A new species of Lepophidium from the Caribbean Sea. Bull. Mar. Sci. Gulf Caribb. 8:360-368.

1959. Studies on fishes of the family Ophidiidae. III. A new species of Lepophidium from Barbados. Breviora 104, $7 \mathrm{p}$.

1960. Studies on fishes of the family Ophidiidae.-V. Lepophidium pheromystax, a new Atlantic species allied to Lepophidium jeannae Fowler. Bull. Mar. Sci. Gulf Caribb. 10:83-95.

1961. Studies on fishes of the family Ophidiidae. - VI. Two new genera and a new species from American waters. Copeia 1961: $212-221$.

1962. Studies on fishes of the family Ophidiidae. - VII. The Pacific species of Lepophidium. Copeia 1962:487-498.

ROBINS, C. R., and J. E. BÖHLKE.

1959. Studies on fishes of the family Ophidiidae. IV. Two new dwarf cusk-eels (genus Ophidion) from the tropical western Atlantic. Acad. Nat. Sci. Phila. Not. Nat. 325, 9 p.

ROBINS, C. R., and R. N. LEA.

1976. Xiphiurus Smith, 1847, proposed suppression in favour of Genypterus Philippi, 1857 (Pisces, Ophidiidae). Bull. Zool. Nomencl. 33:90-93.

ROBINS, C. R., and J. G. NIELSEN.

1970. Snyderidia bothrops, a new tropical, amphi-Atlantic species (Pisces, Carapidae). Stud. Trop. Oceanogr. (Miami) 4:285-293.

ROSE, J. A.

1961. Anatomy and sexual dimorphism of the swim bladder and vertebral column in Ophidion holbrooki (Pisces: Ophidiidae). Bull. Mar. Sci. Gulf Caribb. 11:280-308.

ROSEN, D. E., and C. PATTERSON

1969. The structure and relationships of the paracanthopterygian fishes. BuIl. Am. Mus. Nat. Hist. 141:357-474.

ROSENBLATT, R. H.

1961. A new pearlfish (family Carapidae) from the Gulf of California. Proc. Biol. Soc. Wash. 74:207-212.

ROULE, L.

1913. Notice préliminaire sur Grimaldichthys profundissimus, nov. gen., nov. sp. Poisson abyssal recueilli à 6.035 mètres de profondeur dans l'Ocean Atlantique par S.A.S. le Prince de Monaco. Bull. Inst. Océanogr. Monaco 261, 8 p. 
1916. Notice prẻliminaire sur quelques espèces nouvelles ou rares des Poissons provenant des croisières de S.A.S. le Prince de Mon-

$\mathrm{SATO}$.

aco. Bull. Inst. Océanogr. Monaco 320, 31 p.

1962. Miocene fishes from the western area of Shizukuishi Basin, Iwate Prefecture, northeastern Japan. Earth Sci. (Tokyo) 59: $1-29$

SCHLITZ. L. P.

1960. Suborder Ophidina. In L. P. Schultz, W. M. Chapman, E. A. Lachner, and L. P. Woods, Fishes of the Marshall and Marianas Islands. Bull. U.S. Natl. Mus. 202(2):382-396.

SHAKLEE. J. B., K. L. KEPES, and G. S. WHITT

1973. Specialized lactate dehydrogenase isozymes: the molecular and genetic basis for the unique eye and liver LDHs of teleost fishes. J. Exp. Zool. 185:217-240.

SHCHERBACHEV, YU. N.

1976. New species of the family Aphyonidae from the Indian Ocean (Pisces, Ophidioidea). Vopr. Ikhtiol. 16:162-165.

S.ITH A

1838-47. Pisces. In Illustrations of the zoology of South Africa. vol. 4, 77 p. Smith, Elder and Co., Lond.

SМTTH. J. L. B.

1934. Marine fishes of seven genera new to South Africa. Trans. R. Soc. S. Afr. 22:89-100.

1943. Interesting new fishes of three genera new to South Africa, with a note on Mobula diabolus (Shaw). Trans. R. Soc. S. Afr. $30: 67-77$.

1947. Brief revisions and new records of South African marine fishes. Ann. Mag. Nat. Hist., Ser. 11, 14:335-346.

1955a. The genus Pyramodon Smith \& Radcliffe, '1913. Ann. -Mag. Nat. Hist., Ser. 12, 8:545-550.

1955b. The fishes of the family Carapidae in the Western Indian Ocean. Ann. Mag. Nat. Hist., Ser. 12, 8:401-416.

1966. Interesting fishes from South Africa. Dep. Ichthyol. Rhodes Univ. Occas. Pap. 8:83-94.

STAIGER, J. C.

1972. Bassogigas profundissimus (Pisces; Brotulidae) from the Puerto Rico Trench. Bull. Mar. Sci. 22:26-33.

STEINDACHNER, F., and L. DÖDERLEIN.

1887. Beiträge zur Kenntniss der fische Japan's. (IV). Denksch. K. Akad. Wiss. Wien, Math. - Naturwiss. cl. 53:257-296.

STRASBURG, D. W

1965. Description of the larva and familial relationships of the fish Snyderidia canina. Copeia 1965:20-24.

SUAREZ, S. S.

1975. The reproductive biology of Ogilbia cayorum, a viviparous brotulid fish. Bull. Mar. Sci. 25:143-173.

SVETOVIDOV, A. N

1961. On European species of the family Ophidiidae and on the functional importance of the structure specificity of their fishsound. Vopr. Ikhtiol. 17:3-13. (NMFS Syst. Lab. Transl. 41.)

SWAINON, W. R.

1838. The natural history of fishes, amphibians and reptiles, or monocardian animals. Vol. 1, 368 p. Longman, Orme, Brown, Green and Longmans, Lond.

TEMMINCK, C. J., and H. SCHLEGEL.

1846. Pisces. In P. F. von Siebold (editor), Fauna Japonica, part 5, p. 173-269. Leiden.

TORO, H., and G. DAZAROLA.

1969. Contribucion a la osteologia de las especies Chilenas del genero Genypterus (Ophidiidae). An. Mus. Hist. Nat. (Santiago) $2: 183-224$

TORRE y HUERTA, C. de la.

1930. Un pez de nueva especie, el "Benthocometes claudei Torre" cogido en el tubo de la planta de M. Claude, Rev. Soc. Geográf. Cuba $3: 170-171$.

TORTONESE, E.

1954. On Ophidion vassali Risso, type of a new genus of ophidiid fishes (Parophidion). Publ. Staz. Zool. Napoli 25:372-379.

TROTT, L. B.

1970. Contributions to the biology of carapid fishes (Paracanthopterygii: Gadiformes). Univ. Calif. Publ. Zool. 89, 41 p.

1972. Jordanicus sagaminus (Tanaka) (Paracanthopterygii: Gadiformes): a redescription. UO 7:1-7.

TROTT, L. B., and E. E. TROTT.

1972. Pearlfishes (Carapidae: Gadiformes) collected from Puerto Galera, Mindoro, Philippines. Copeia 1972:839-843.

TROTTER, E. S.

1926. Brotulid fishes from the Arcturus Oceanographic Expedition Zoologica (N.Y.) 8:107-125.

TSCHUDI, J. J. von.

1844-46. Untersuchungen über die Fauna Peruana. St. Gallen, $693 \mathrm{p}$.

TYLER, J. C.

1970. A redescription of the inquiline carapid fish Onuxodon parvibrachium, with a discussion of the skull structure and the host. Bull. Mar. Sci. 20:148-164

VAILLAN'T, L.

1888. Expéditions scientifiques du Travailleur et du Talisman pendant les annees 1880, 1881, 1882, 1883. Poissons. G. Masson, Paris, 406 p.

VAN MOL, J. J.

1967. Ecologie comparée de deux espèces de Brotulidae (Pisces) des îles Galapagos: Caecogilbia deroyi Poll et Van Mol 1967 et C. galapagosensis Poll et Leleup 1965. Bull. Acad. R. Belg. cl. Sci. Ser. 5, 53:232-248.

WAITE, E. R.

1905. Notes on fishes from Western Australia. Rec. Aust. Mus. 6: 55-82.

WEBER, M

1913. Die fische der Siboga-Expedition. Uitkomsten Zool. Bot., Oceanogr. en Geol. Gebied, vol. 65 (monogr. 57), 710 p.

WHITLEY, G. P.

1928. Fishes from the Great Barrier Reef collected by Mr. Melbourne Ward. Rec. Aust. Mus. 16:294-304.

1936. More ichthyological miscellanea. Mem. Queensl. Mus. $11: 23-51$.

1941. Ichthyological notes and illustrations. Aust. Zool. 10:1-50.

1951. New fish names and records. Proc. R. Zool. Soc. N.S.W. 1949-50:61-68.

WOOD-MASON, J., and A. ALCOCK.

1891. Natural history notes from H.M. Indian Marine Survey Steamer 'Investigator,' commander R. F. Hoskin, R.N., commanding.--Ser. II, No. 1. On the results of deep-sea dredging during the season 1890-1891. Ann. Mag. Nat. Hist., Ser. 6, 8:16-34.

WOODS, L. P., and R. H. KANAZAWA.

1951. New species and new records of fishes from Bermuda. Fieldiana: Zool. 31:629-644.

WOURMS, J. P., and O. BAYNE.

1973. Development of the viviparous brotulid fish Dinematichthys ilucoeteoides. Copeia 1973:32-40.

WOURMS, J. P., and D. M. COHEN.

1975. Trophotaeniae, embryonic adaptations, in the viviparous ophidioid fish, Oligopus longhursti: a study of museum specimens. J. Morphol. 147:385-402.

ZUGMAYER, E

1911. Diagnoses des poissons nouveaux provenant des campagnes du yacht "Princesse-Alice" (1901 à 1910). Bull. Inst. Océanogr. Monaco 193, 14 p. 


\section{INDEX TO GENUS AND SPECIES NAMES}

abyssalis

Abyssobrotula

abyssorum

Abythites

Acanthonus

acer

acus

acutus

aequatoris

affinis

agassizii

Alcockia

alcockii

Alexeterion

alleni

americanum

analis

Aphyonus

apoda

aporrhox

argenteum

armata

armatum

armatus

armiger

asiro

ater

atlanticus

atripectus

Barathrites

Barathrodemus

Barathronus

barbata.

barbatum

barbatus

Barbuliceps

bartsch

Bassobythites

Bassogigas

Bassozetus

Bathynectes

Bathyonus

Bathystorreus

beani

Bellottia

Benthocometes

bermudensis

bicolor .....................61,62

Bidenichthys ................52,53

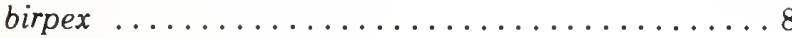

blacodes........................... 14

bolini ........................61

boraborensis ..................... 8

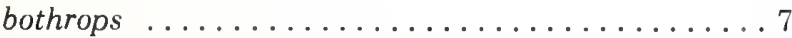

Brachydicrolene .................. 28

brachysoma .................... 47

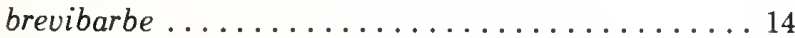

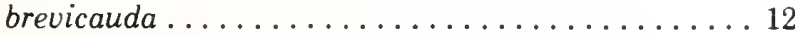

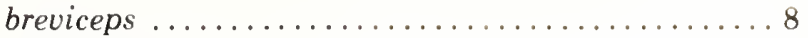

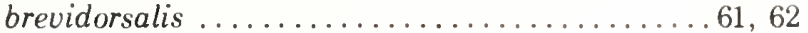

brevis .....................46, 47

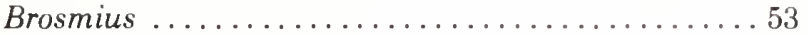

Brosmophyciops ................. 52,53

Brosmophycis .................... 52, 53

Brotella ............................. 19

Brotula ...................3,6, 11, 19, 40

Brotulotaenia ................6, 10, 12

Brotulina ..................... 54,56

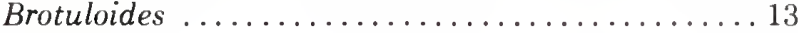

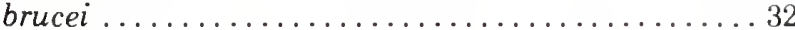

brunnea .......................... 47

brunswigi ............................ 26

bruuni ....................47,62

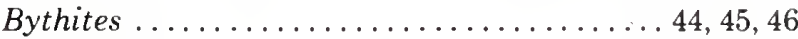

Caecogilbia ................... 54,60

caecus ............................... 59

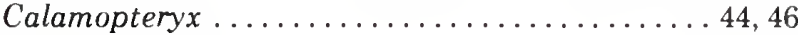

Calcarbrotula ..................54,56

canina ........................... 7

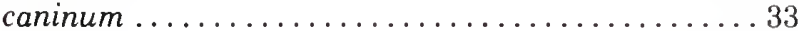

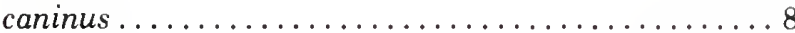

capensis ...................13, 14, 53

Carapus .................... 8, 9, 10

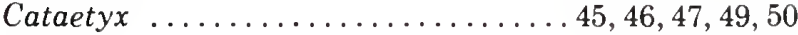

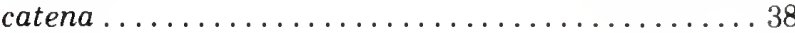

caudalis ......................... 28

cayorum ........................... 60

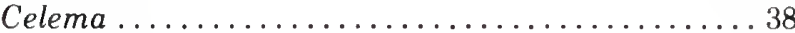

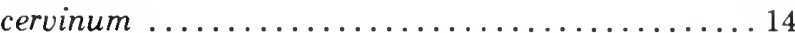

Cherublemma........................ 13

chickcharney ......................... 16

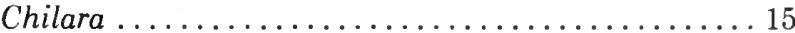

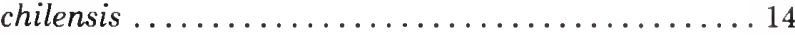

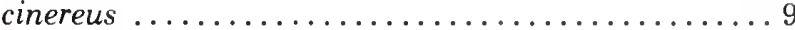

clarkae .......................... 11

claudei ..............................49

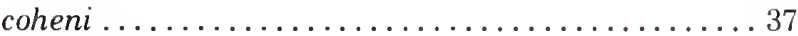

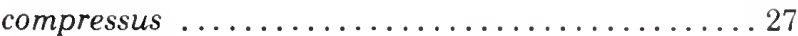

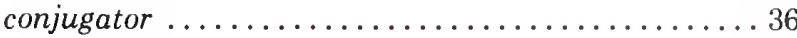

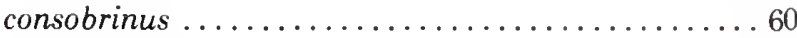

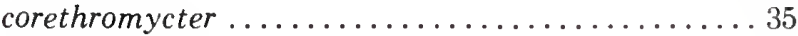

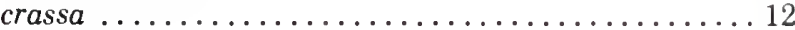

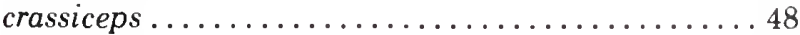

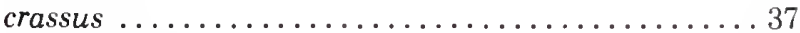

cryptophthalmus ...............62,63

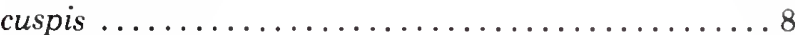

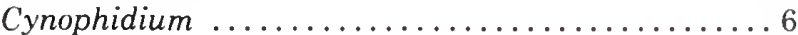

Dannevigia .......................18, 19

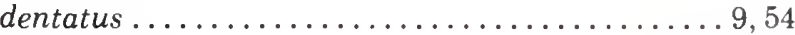

Dermatopsis ............... 55,56,57,59

Dermatopsoides ................... 55, 57

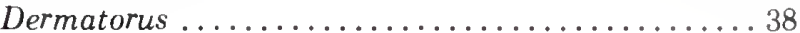

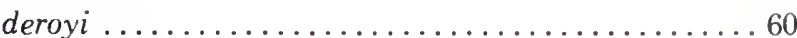

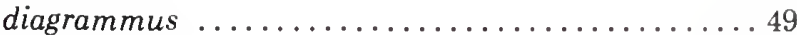

Diancistrus .................... 55,57

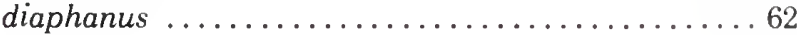


Dibrolene...................23, 28, 35

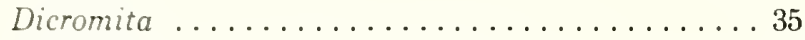

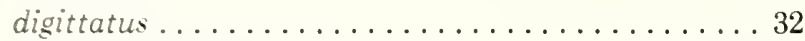

Dinematichthys........... . 5, 54,55, 57, 58

Diplacanthopoma ...........44,46, 47, 48, 50

Dipulus ......................55, 59

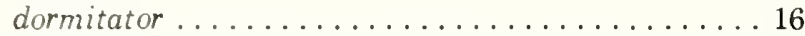

douvillei.....................49, 50

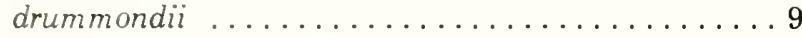

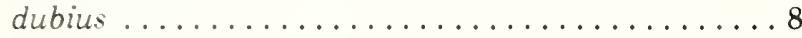

Echiodon ................... 8, 9, 10

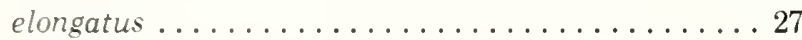

emmelas .......................... 13

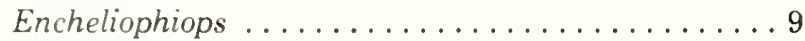

Encheliophis ................... 7,9

Enchelybrotula ................21, 25, 29

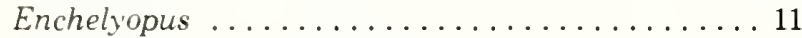

ensiformis .......................11

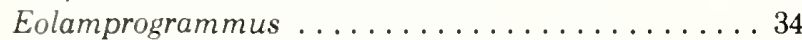

Epetriodus ............... 1, 22, 29, 30, 31

Eretmichthys ...............23, 27,31

erikssoni .......................62

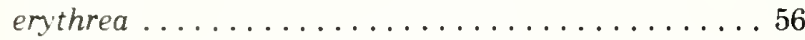

erythrops ..........................62

Eutyx.......................... 51

everriculi........................20

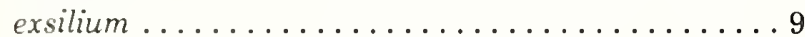

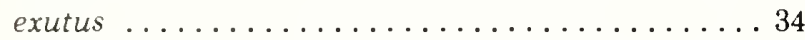

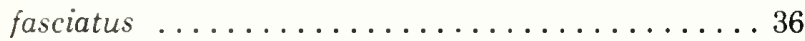

ferruginosus ....................... 11

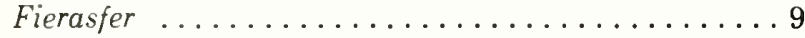

filamentosa ...................... 29

fluminense ..................... 17

fluminensis ........................ 17

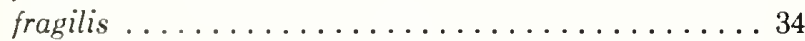

freddyi .......................... 30

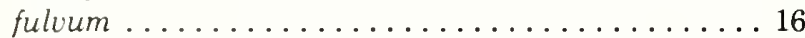

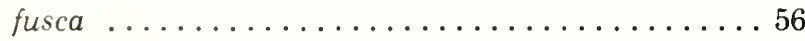

fuscus .......................... 46

Gadopsis ...................... 5, 49

galapagosensis ...................6 60

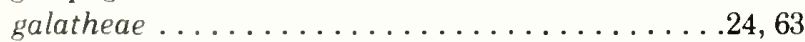

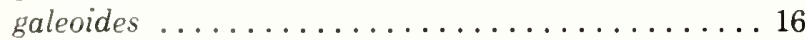

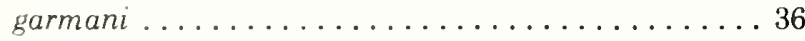

gelatinosus ......................61

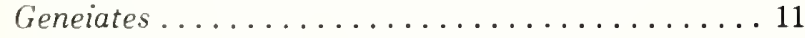

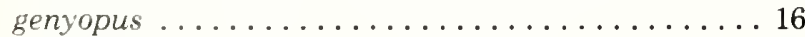

Genypterus ........................... 16

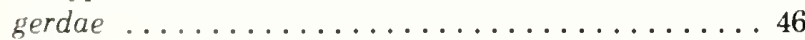

gillii ......................26, 27, 36

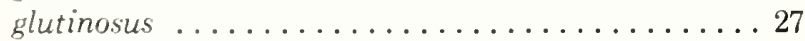

Glyptophidium ...............22,32,34

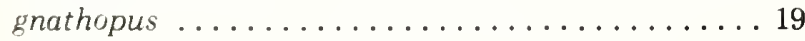

goslinei ......................... 46

gracilis ...................... 9, 38

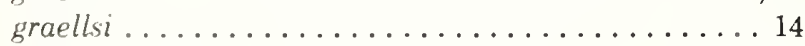

Grammonus.......................47, 49

Grammonoides ...............43,47,48

grandis............................. 37

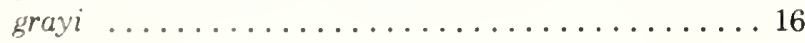

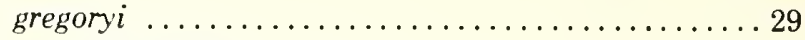

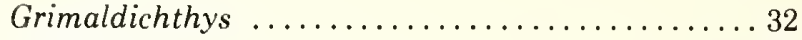

guentheri ............................. 38, 39

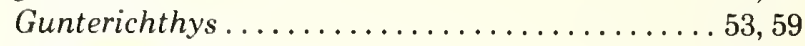

Gymnotus .......................... 8

Halias ............................... 53

hancocki............................ 9

hawaii.............................. 50

hawaiiensis ..........................47

Hephthocara .......................43, 48

hextii ...............................20

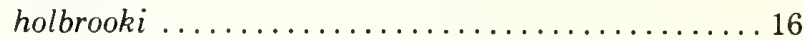

Holcomycteronus ............... 4, 23, 27, 29, 32

homei ............................ 8

Homostolus ..................... 23, 32, 36

hopkinsi ......................... 37, 38

Hoplobrotula ...................... 18, 19

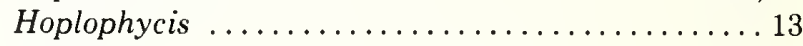

houlti ............................. 8

hubrechti ..............................29

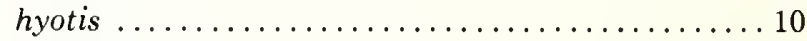

Hypopleuron ....................22, 23, 34

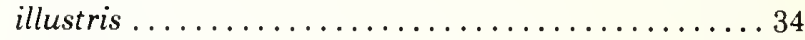

iluocoeteoides ....................... 57, 58

imberbis ............................ 19, 20

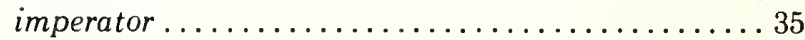

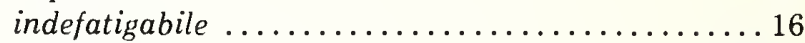

intronigra ........................ 28, 29

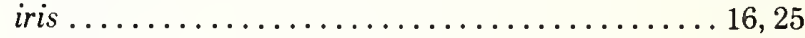

islandicus ........................... 46

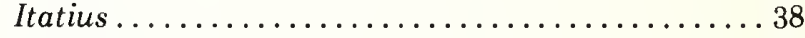

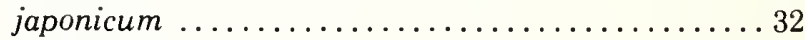

japonicus .............................. 43

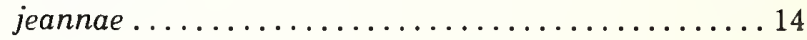

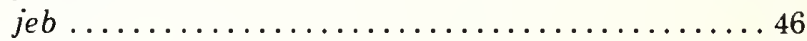

jerdoni ............................... 20

jonassoni ............................66

jordani .......................... 9, 47

Jordanicus .......................... 9

kagoshimanus ........................... 8

kallion ............................... 14

kanazawai .........................28, 29

kasougae ............................ 57

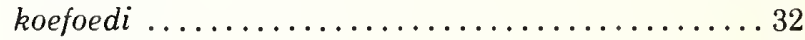

kullenbergi ...........................63

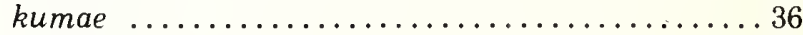

lagochila ............................. 16

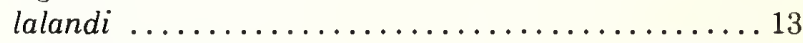

Lamprogrammus ............10, 12, 17, 21, 26, 33, 34

latebricola ............................ 51

laticeps........................ 27, 28, 47

lelepris ................................ 13

lepidogenys .......................... 45

Lepophidium ........................ 14, 17

Leptophidium ........................13, 14

Leucicorus ........................ 3, 21, 34

Leucochlamys .....................62, 63

leucos ...............................47

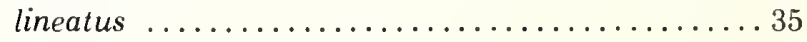

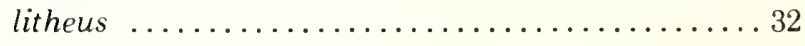


longhursti

longiceps

longifilis

longimana

longipenis

longipes

lucidum

Lucifuga

Luciobrotula

luciosus

macdonaldi

macrodon

macrops

macropterus

macropus

maculata

maculatus

mahodadi

malayanus

malispinosus

manatinus

margaritiferae

marginata

marginatum

marginatus

marmoratum

Mastigopterus

matsubarai

melampeplus

melanocephalus

memoriabilis

messieri

Meteoria

metriostoma

Microbrotula

microlepis

mircophthalmus

microps ...........................26

microstomus ........................ 14

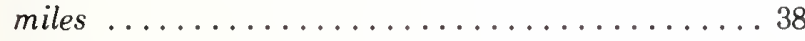

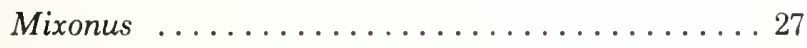

mizolepis .....................60 60

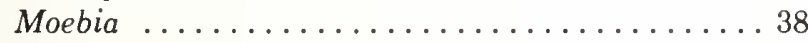

mollis............................61

Monomeropus ......................35, 36

Monomitopus ............23, 33, 35, 36, 39

Monothrix................ 54, 55, 59, 60

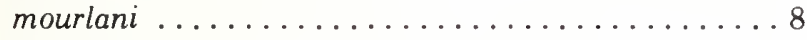

mowbrayi........................... 49

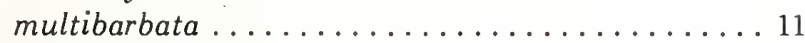

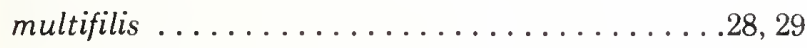

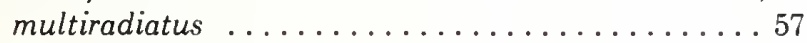

muraenolepis ........................ 26

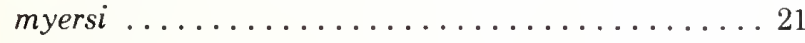

Myxocephalus ................... 47

nasus ...................... 27, 41, 42

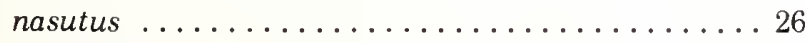

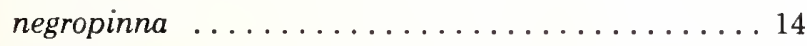

nelsoni........................... 52

Nematobrotula .........................
Nematonus ............................27 27

Neobythites ..................... 24, 28, 36

nielseni ................................ 12

niger ................................................ 49

nigra .......................... 12, 29, 49

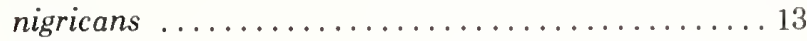

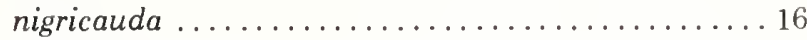

nigricaudis ........................... 28, 29

nigripinnis ....................... 35, 36, 47

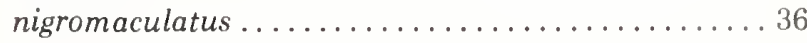

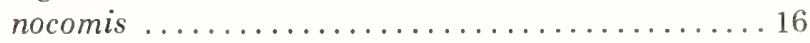

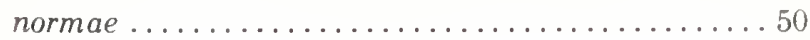

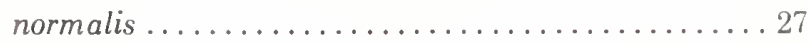

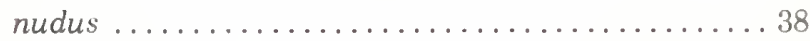

Nybelinella ..........................61, 62

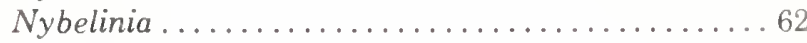

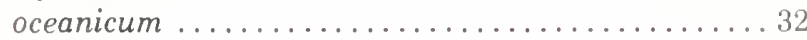

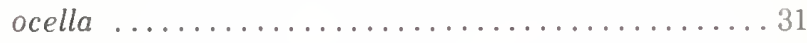

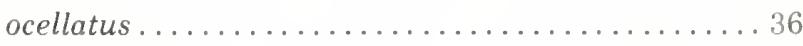

Oculospinus .....................46,47

Ogilbia..................... 3,52,54, 56, 60

Oligopus...................44,48,49,51

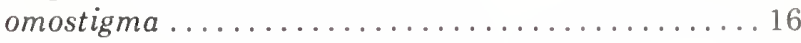

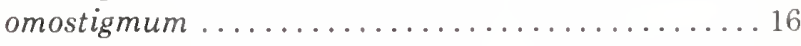

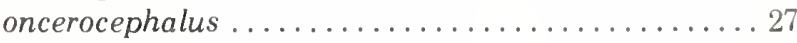

Onuxodon ...........................8, 9, 10

opisthodon.......................47,48

Ophidion .......................14, 15, 16, 17

Ophidium .........................15, 16

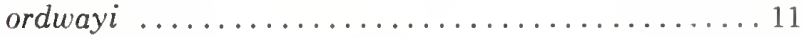

Otophidium.......................... 15, 16

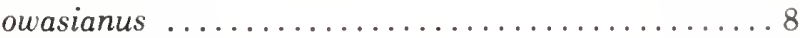

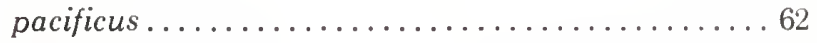

pallidus ............................... 36

Parabassogigas ............21, 22, 24, 25, 29, 36, 40

Paradicrolene .......................... 28

pardale ................................ 14

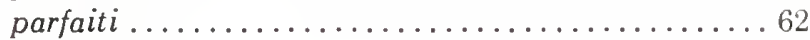

Parophidion ........................ 15, 16, 17

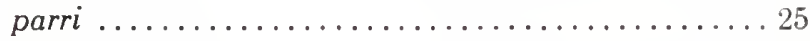

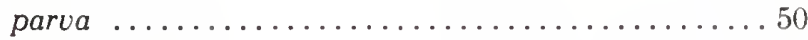

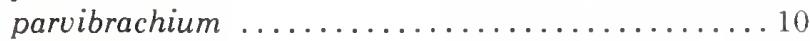

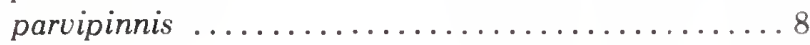

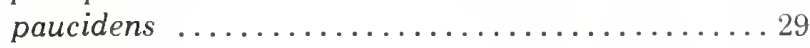

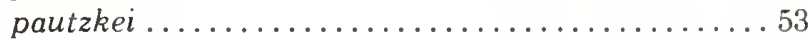

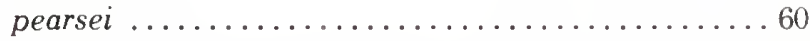

pectoralis......................... 27, 28

pedicellaris ........................6. 62, 63

pelagica ........................... 51,52

Penopus......................23, 37, 38

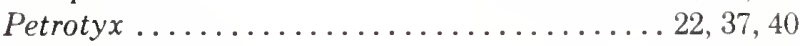

pheromystax .......................... 14

philippinus ......................... 19, 20

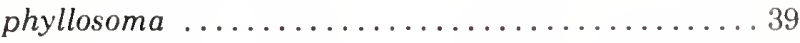

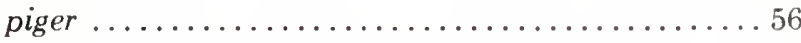

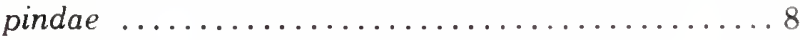

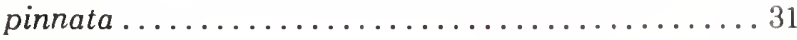

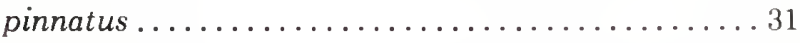

platycephalus ..........................50

polylepis.............................6 60 
Porogadus

$23,25,27,37,38$

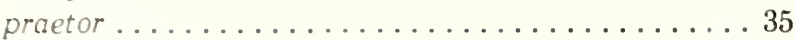

profundissimus ...................24,32

profundorum ...................... 14

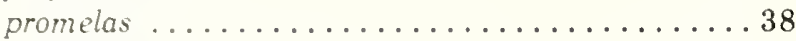

Propteridium ................42, 45, 49

prorates .......................... 14

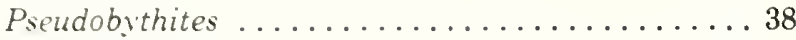

Pseudonus ..................44,47,50

Pteridium ......................... 28

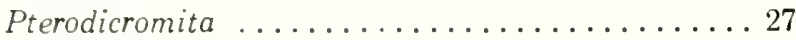

Pteroidonus ......................28

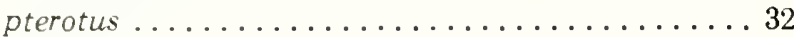

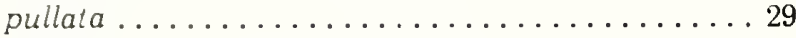

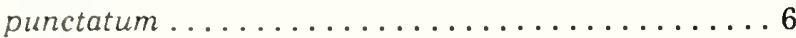

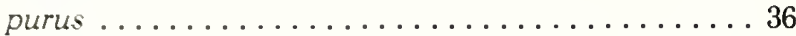

Pycnocraspedum ..............22, 38, 40

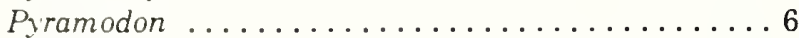

quinquarius ......................28, 29

radcliffei ........................... 40

randalli ........................ 49

Raneya ............................. 17

raniceps ......................... 47

rassi .........................61

reedi........................... 10

remifer.............................

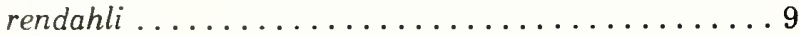

Rissola .......................... 16

rivers-andersoni................... 47

robinsorum .................... 46

robustus ...................27, 28, 49

rochei.......................... 16

rostrata ......................... 25

rostratus .......................25

rubra .......................... 49

rubrirostris ...................... 47

Saccogaster .................... 43, 50

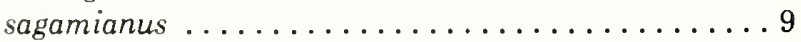

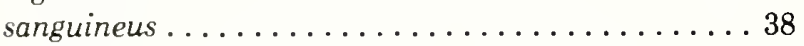

Sarcocara....................... 47

schmidti .......................... 17

Sciadonus ..................61, 62, 63

scrippsae ......................... 16

Selachophidium ..............24, 33, 36, 39

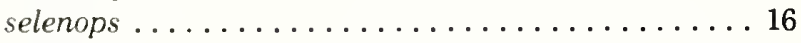

simum ...................... 48

simus ...................... 47

Sirembo ............. 18, 19, 27, 28, 35, 36, 46

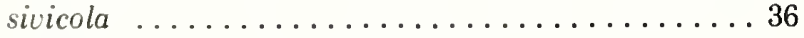

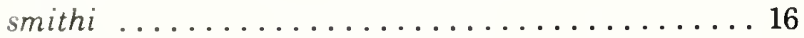

Snyderidia .....................6, 7

Spectrunculus ...............22, 37, 39, 40

spelaeotes ...................... 54

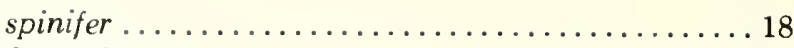

Spottobrotula ................ 1, 23, 35, 39, 40, 41

squamiceps .......................... 50

squamipinne ..........................38, 39

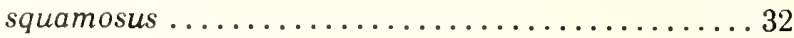

staigeri ............................. 50

staurophor ........................... 14

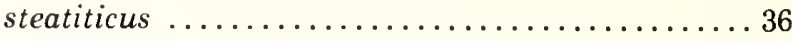

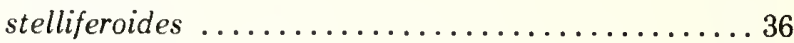

stigmatistium ............................ 14

Stygicola .............................54

Stygnobrotula.................... 5, 43,51

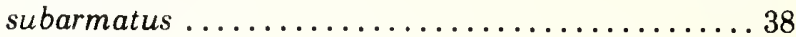

subterraneus ............................54

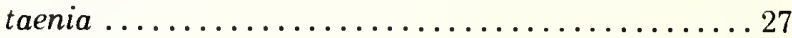

talboti................................. 57

Tauredophidium ................4, 5, 17, 18, 20

taylori................................ 15

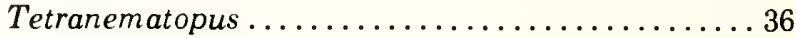

Thalassobathia .................5, 42, 43, 51, 58

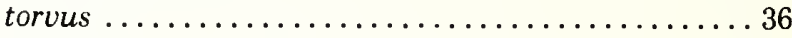

townsendi $\ldots \ldots \ldots \ldots \ldots \ldots \ldots \ldots \ldots \ldots \ldots \ldots$

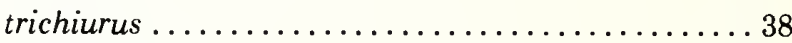

tristis ................................29

tubercularis ..............................50

tuberculata ....................... 50

tuberculatus ........................... 50

tumidirostris ........................... 51

tusca ................................. 19

Typhlias..............................6 60

Typhliasina .........................54, 60

Typhlonus ........................21, 41

Umalius ............................... 19

umbratilis .............................. 9

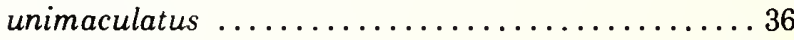

Urenchelys.......................... 49

vaillanti ................................ 29

variegatus ............................. 8

vassali ................................ 17

ventralis ..............................., 7, 60

Verater................................49

ve. micularis ............................. 9

verrillii ..............................6 60

vitaizi ................................ 36

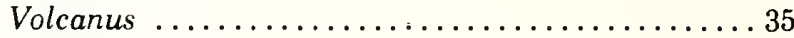

waikiki ............................... 49

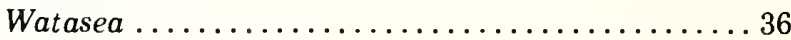

welshi ................................. 16

Xenobythites .........................45

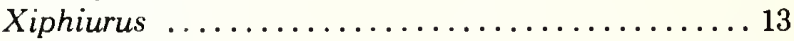

Xyelacyba ...................... 17, 18, 20

zenkevitchi ......................... 27 
388. Proceedings of the first U.S.-Jlapan meeting on aquaculture at Toki, Tapan, October 18-19, 1971. William N. Shaw (editor). (18 papers, 14 authors.) February 1974, iii +133 p. For sale by the Suptrintendent of Documents, U.S. Government Printing Office, Washington. I).C. 20402

389. Marine thora and fauna of the northeastern United States Crustacea: Decapoda. By Austin B. Williams. April 1974, iii + 50 p., 111 figs. For sale by the Superintendent of Documents, U.S. Government Printing Office, Washington, D.C. 20402.

390. Fishery publications, calendar year 1973: Lists and indexes. By Mary Ellen Engett and Lee C. Thorson. September 1974, iv + 14 p., 1 fig For sale by the Superintendent of Documents. U.S. Government Printing Office, Washington, D.C. 20402.

391. Calanoid copepods of the genera Spinocalanus and Mimocalanus from the central Arctic Ocean, with a review of the Spinocalanidae. By

David M. Damkaer. June 1975, x +88 p., 225 figs., 4 tables. For sale by the Superintendent of Documents, U.S. Government Printing Office. Washington, I).C. 20.402.

392. Fishery publications, calendar year 1974: Lists and indexes. By l.ee C. Thorson and Mary Ellen Enget1. June 1975, iv + 27 p. 1 fig

393. Cooperative Gulf of Mexico estuarine inventory and study-Texas: Area description. By Richard A. Diener. September 1975, vi $+129 \mathrm{p}$ 5.5 figs., 26 tahles.

394. Marine Flora and Fauna of the Northeastern L'nited States. Tar digradi. By leland W. Pollock. Mav 1976, iii +25 p., figs. For sale he the Superintendent of Documents. U.s. Government Printing Office. Washington. D.C.2(1) 40 .

395. Report of a colloquium on larval fish mortality studies and their relation to fishery research, January 1975. By John R. Hunter. May 1976, iii +5 p. For sale by the Superintendent of Documents, IIS Government Printing Office. Washington, D.C. 20402. 
UNITED STATES

\section{NOAA SCIENTIFIC AND TECHNICAL PUBLICATIONS}

NOAA, the National Oceanic and Almospheric Administration, was established as part of the Department of Commerce on October 3, 1970. The mission responsibilities of NOAA are to monitor and predict the state of the solid Earth, the oceans and their living resources, the atmosphere, and the space environment of the Earth, and to assess the socioeconomic impact of natural and technological changes in the environment.

The six Major Line Components of NOAA regularly produce various types of scientific and technical information in the following kinds of publications:

PROFESSIONAL PAPERS-Important definitive research results, major techniques, and special investigations.

TECHNICAL REPORTS-Journal quality with extensive details, mathematical developments, or data listings.

TECHNICAL MEMORANDUMS-Reports of preliminary, partial, or negative research or technology results, interim instructions, and the like.

CONTRACT AND GRANT REPORTS-Reports prepared by contractors or grantees under NOAA sponsorship.
TECHNICAL SERVICE PUBLICATIONSThese are publications containing data, observations, instructions, etc. A partial listing: Data serials; Prediction and outlook periodicals; Technical manuals, training papers, planning reports, and information serials; and Miscellaneous technical publications.

ATLAS-Analysed data generally presented in the form of maps showing distribution of rainfall, chemical and physical conditions of oceans and atmosphere, distribution of fishes and marine mammals, ionospheric conditions, etc.

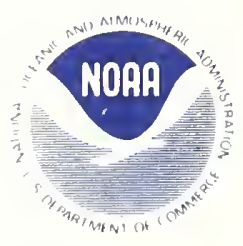

Information on avallabllity of NOAA publlcatlons can be obtalned from:

ENVIRONMENTAL SCIENCE INFORMATION CENTER ENVIRONMENTAL DATA SERVICE NATIONAL OCEANIC AND ATMOSPHERIC ADMINISTRATION U.S. DEPARTMENT OF COMMERCE 